\title{
Pesquisas linguísticas pautadas em corpora
}

\author{
Daniel Soares da Costa (org.)
}

COSTA, DS., org. Pesquisas linguísticas pautadas em corpora [online]. São Paulo: Editora UNESP, 2014, 230 p. ISBN 978-85-68334-41-6. Available from SciELO Books $<$ http://books.scielo.org $>$.

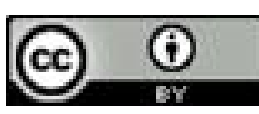

All the contents of this work, except where otherwise noted, is licensed under a Creative Commons Attribution 4.0 International license.

Todo o conteúdo deste trabalho, exceto quando houver ressalva, é publicado sob a licença Creative Commons Atribição $\underline{4.0}$.

Todo el contenido de esta obra, excepto donde se indique lo contrario, está bajo licencia de la licencia Creative Commons $\underline{\text { Reconocimento } 4.0 .}$. 


\section{Pesquisas LINGUÍSTICAS PAUTADAS EM CORPORA}




\title{
FUNDAÇÃO EDITORA DA UNESP
}

\author{
Presidente do Conselho Curador \\ Mário Sérgio Vasconcelos \\ Diretor-Presidente \\ José Castilho Marques Neto \\ Editor-Executivo \\ Jézio Hernani Bomfim Gutierre
}

Superintendente Administrativo e Financeiro

William de Souza Agostinho

Assessores Editoriais

João Luís Ceccantini

Maria Candida Soares Del Masso

Conselho Editorial Acadêmico

Áureo Busetto

Carlos Magno Castelo Branco Fortaleza

Elisabete Maniglia

Henrique Nunes de Oliveira

João Francisco Galera Monico

José Leonardo do Nascimento

Lourenço Chacon Jurado Filho

Maria de Lourdes Ortiz Gandini Baldan

Paula da Cruz Landim

Rogério Rosenfeld

Editores-Assistentes

Anderson Nobara

Jorge Pereira Filho

Leandro Rodrigues 


\section{DANIEL SOARES DA COSTA \\ (Org.)}

\section{Pesquisas \\ LINGUÍSTICAS PAUTADAS EM CORPORA}


(C) 2014 Editora Unesp

Direitos de publicação reservados à:

Fundação Editora da Unesp (FEU)

Praça da Sé, 108

01001-900 - São Paulo - SP

Tel.: (0xx11) 3242-7171

Fax: (0xx11) 3242-7172

www.editoraunesp.com.br

www.livrariaunesp.com.br

feu@editora.unesp.br

CIP - BRASIL. Catalogação na publicação

Sindicato Nacional dos Editores de Livros, RJ

P564

Pesquisas linguísticas pautadas em corpora / Organização Daniel

Soares da Costa. São Paulo: Editora Unesp Digital, 2015.

Recurso digital

Formato: ePDF

Requisitos do sistema: Adobe Acrobat Reader

Modo de acesso: World Wide Web

ISBN 978-85-68334-41-6 (recurso eletrônico)

1. Linguística. 2. Língua portuguesa - Fonologia. 3. Escrita.

4. Semântica. 5. Livros eletrônicos. I. Costa, Daniel Soares da.

15-20464

CDD: 401.41

CDU: 81'42

Este livro é publicado pelo projeto Edição de Textos de Docentes e

Pós-Graduados da UNESP - Pró-Reitoria de Pós-Graduação

da UNESP (PROPG) / Fundação Editora da Unesp (FEU)

Editora afiliada:

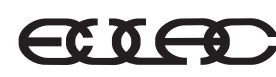

Asociación de Editoriales Universitarias

de América Latina y el Caribe

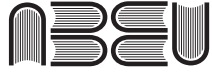

Associação Brasileira de Editoras Universitárias 


\section{SUMÁRIO}

Prefácio 7

Ariel Novodvorski

Apresentação 11

Daniel Soares da Costa

1 O uso anafórico dos pronomes demonstrativos no português contemporâneo 15

Talita de Cássia Marine

2 Uma análise sócio-histórico-linguística da posição dos clíticos pronominais em textos jornalísticos paulistanos (1880-1920) 51

Caroline Carnielli Biazolli

3 Estudo diacrônico do pretérito perfeito no português do Brasil 85

Juliana Bertucci Barbosa

4 O estudo da temporalidade verbal na língua espanhola: contribuições à dialetologia argentina 111

Leandro Silveira de Araujo

5 A variação da concordância verbal no português popular da cidade de São Carlos 153

Alexandre Monte 
6 O texto poético no estudo das vogais do português antigo 175

Juliana Simões Fonte e Gladis Massini-Cagliari

7 Análise da atribuição do acento lexical no português arcaico: uma abordagem por meio da música e do texto de cantigas trovadorescas 211

Daniel Soares da Costa 


\section{Prefácio}

Como diria Giovanni Parodi (2010), em seu livro Linguística de Corpus: da teoria à empiria, "parecem tempos em que ser linguista de corpus é uma aventura adequada”. Se pensarmos em que, neste ano de 2014, se comemoram cinquenta anos do Corpus Brown (1964) e que, especificamente no contexto brasileiro, a obra Linguística de Corpus, de Berber Sardinha (2004), completa dez anos de existência, as palavras do professor Parodi adquirem fundamental significância e não poderiam definir melhor o momento atual. Tais retomadas comemorativas, por um lado, trazem à memória alguns marcos históricos importantes; mas, acima de tudo, levam a uma reconstrução do próprio processo, na constituição da área que hoje reconhecemos como Linguística de Corpus.

Se nos inícios da década dos sessenta, em pleno contexto histórico gerativista, questionava-se a importância de coletar dados dos usos linguísticos para as pesquisas, porque a perspectiva da época presumia que os dados estariam na mente do linguista, uma vez que o falante nativo de uma língua era entendido como "corpus vivente" (Sánchez, 1996) e que o acesso aos dados precisaria apenas de um exercício de introspecção, o surgimento do Corpus Brown teve um valor pioneiro incalculável e um efeito propulsor dos estudos baseados em corpora, já apontados por diversos autores. A 
mudança de paradigma significou um caminho que conduziu da idealização à sistematização da observação de evidências.

Atualmente, a expansão do uso dos termos corpus e corpora e de muitos de seus pressupostos básicos, de atributos e procedimentos caros à Linguística de Corpus, alcançam áreas que poderiam parecer, num primeiro momento, incompatíveis ou inimagináveis. Contudo, a alusão à terminologia que configura tal vertente de investigação vem se tornando cada vez mais recorrente. Em eventos científicos, em publicações, em nomes de disciplinas, teses e dissertações, a recorrência com que aparecem essas referências denotam já uma presença marcada no plano acadêmico e são um bom termômetro do estado da arte.

Parafraseando Fillmore (1992), sabemos que nenhum corpus nos dá resposta para tudo, mas que todo corpus sempre traz questões novas ou questões que não se imaginava encontrar. Nesse sentido, as observações, experimentos e hipóteses formuladas no âmbito de toda investigação nos conduzem a uma revisão à luz das comprovações e dos resultados. Já em 1899, o médico espanhol Ramón y Cajal, destacando a falta de inspiração na criação de muitas teorias da época, apontou a importância no exame direto dos fatos da natureza e no uso de métodos que se caracterizassem pelo poder de reduzir o máximo possível fatores subjetivos. Com isso, toda observação de dados para sua posterior descrição exigiria, necessariamente, fundamentações teóricas e princípios metodológicos; mas, principalmente, o traçado de caminhos de ida e volta para a própria revisitação dos dados e ajustes dos pressupostos iniciais, a partir dos quais toda pesquisa procura ocupar um lugar.

A sistematização de dados e de observações chega a ser tão extraordinária ou, quiçá, mais importante do que a simples aplicação e contraste de teorias. Para Hanson (1958), os problemas não residem tanto na aplicação de teorias ou na comprovação de hipóteses, mas em sua descoberta e na identificação de padrões a partir da observação. Esse autor afirma que toda teoria é o resultado de um trabalho consciente sobre os dados, uma vez que a tarefa das teorias é colocar fenômenos em sistemas. Definindo-as como um conjunto 
de conclusões em busca de premissas, Hanson aponta que, nesse sentido, as teorias são construídas para atrás. Asseverações dessa natureza nos levam à compreensão da relevância dada aos processos de observação, nas fases de descoberta.

Este breve prefácio ao livro Pesquisas linguísticas pautadas em corpora busca contextualizar o momento particular em que surge a presente obra, já definido como um marco histórico em que se constitui uma nova área de pesquisa, com abordagens e métodos próprios. Por outro lado, este texto introdutório também procura focalizar, na figura do corpus, esse caminho de ida e volta, tão bem descrito nas palavras de Ramón y Cajal, junto à importância dada por Hanson à observação. Nessa perspectiva, os corpora se tornam um território vasto o suficiente e propício para a descoberta de evidências, fato que se comprova de modo singular, na obra organizada por Daniel Soares da Costa.

Cada um dos capítulos aqui reunidos, todos fruto de resultados de pesquisa, revelam aspectos definidos claramente por seus autores e coincidem, sem exceção, tanto na pertinência da aproximação à realidade linguística, para a extração e análise de dados, como na importância da definição de métodos criteriosos para a compilação e observação de seus corpora de estudo. A diversidade dos fenômenos linguísticos tratados é outro ingrediente que o leitor poderá encontrar na presente publicação. Dirigida tanto a estudantes de (pós) graduação em Letras, a pesquisadores da área ou dos diferentes assuntos tratados, assim como a interessados pelas interfaces produtivas que resultam das pesquisas de base empírica mediadas pela análise de corpus, esta obra se torna uma referência de importância para o âmbito acadêmico atual.

Ariel Novodvorski

\section{Referências bibliográficas}

BERBER SARDINHA, Tony. Lingüistica de Corpus. Barueri, SP: Manole, 2004. 
FILLMORE, Charles J. Corpus linguistics or computer corpus linguistics. In: SVARTVIK, J. (org). Directions in corpus linguistics. Proceedings of Nobel symposium 82, Stockholm. Berlim/Nova York, De Gruyter, 1992.

HANSON, N. Patrones de descubrimiento: Observación y explicación. Madrid: Alianza Editorial, 1977 [1958].

PARODI, Giovanni. Lingüística de Corpus: de la teoría a la empiria. Madrid: Iberoamericana / Vervuert, 2010.

RAMÓN Y CAJAL, Santiago. Reglas y consejos sobre investigación biológica. Segunda edição do seu discurso lido perante a R.A.C.E.F. e N. Madrid: Imprenta de Fortanet, 1899.

SÁNCHEZ, Aquilino (org.). Cumbre - Corpus Lingüístico del español contemporáneo: fundamentos, metodología y aplicaciones. Madrid: SGEL, 1996. 


\section{ApresentaÇÃo}

A ideia central deste livro é congregar trabalhos de pesquisa linguística que tenham como base para a coleta de dados a organização de algum tipo de corpus linguístico. Portanto, estão contempladas aqui pesquisas em Linguística que analisam fenômenos diferentes, com base em aportes teóricos diferentes, mas que têm em comum o fato de terem sido pautadas em um determinado corpus.

Estão reunidos trabalhos de enfoque tanto sincrônico quanto diacrônico, de cunho variacionista e também formalista, englobando os quatro níveis básicos de análise linguística: o fonológico, o morfológico, o semântico e o sintático.

Sendo assim, podemos afirmar que o objetivo deste livro é demonstrar como a organização de corpora linguísticos diferentes atende aos diversos tipos de pesquisa linguística, sejam eles centrados numa mesma língua - abordando diferentes fenômenos dessa língua - ou focados em outras línguas naturais.

No primeiro capítulo, a professora Talita de Cássia Marine, da Universidade Federal de Uberlândia, partindo de uma perspectiva sociodiscursiva dos fenômenos da linguagem, apresenta uma análise descritivo-comparativa do sistema de pronomes demonstrativos do Português do Brasil e do Português de Portugal, com o intuito de caracterizar a configuração, se ternária ou binária, em que se 
encontram tais pronomes nas referenciações anafóricas no uso contemporâneo dessa língua. Para a realização dessa análise, a autora organizou um corpus constituído por cartas de leitoras da revista brasileira Capricho, e da portuguesa Ragazza, no período de 1994 a 2005.

No Capítulo 2, Caroline Carnielli Biazolli, doutoranda do Programa de Pós-Graduação em Linguística e Língua Portuguesa da Faculdade de Ciências e Letras da Unesp de Araraquara, baseandose nos pressupostos teórico-metodológicos da Teoria da Variação e Mudança Linguística, estudou a posição dos clíticos pronominais, adjungidos a lexias verbais simples e a complexos verbais, presentes em textos do jornal paulistano A Província de São Paulo (que, com o advento da República, em 1890, passou a ser $O$ Estado de São Paulo), entre os anos de 1880 a 1920. A autora avalia o uso de textos jornalísticos como fonte de extração de dados para o estudo de processos de variação e mudança linguística.

No Capítulo 3, a professora-doutora Juliana Bertucci Barbosa, da Universidade Federal do Triângulo Mineiro, faz um estudo descritivo-comparativo do Pretérito Perfeito Simples e do Perfeito Composto do modo Indicativo do Português do Brasil. A autora, realizando um estudo diacrônico em textos escritos do Português Brasileiro, do século XVI ao XX, procura verificar se a forma composta nunca teve os mesmos valores semânticos que a forma simples. Além disso, testa a hipótese de uma caracterização dessas formas verbais, partindo de uma definição semântica abstrata para chegar a uma explicação dos possíveis usos e funções atribuídos às duas formas pretéritas no Português. O corpus analisado pela autora consiste de textos escritos pertencentes a dois grupos - um mais e outro menos formal - escritos em Português Brasileiro, representativos do período que abrange desde o século XVI até o XX.

No quarto capítulo, o professor da Universidade Federal de Uberlândia, Leandro Silveira de Araújo, baseado em um corpus constituído de entrevistas radiofônicas menos formais (disponíveis na rede mundial de computadores), representativas de uma grande cidade de cada região dialetal da Argentina, estuda o uso do 
Pretérito Perfecto Compuesto, no espanhol falado nesse país. Tendo em vista o conceito de isoglossa, o autor delineia três macrorregiões, no país, cujo uso desse tempo verbal se dá de maneira muito semelhante.

No Capítulo 5, Alexandre Monte, doutor em Linguística e Língua Portuguesa pelo Programa de Pós-Graduação em Linguística e Língua Portuguesa da Faculdade de Ciências e Letras da Unesp de Araraquara, adotando os pressupostos teórico-metodológicos da Teoria da Variação e Mudança Linguística ou Sociolinguística Quantitativa, analisa a presença ou a ausência da marca formal de plural no verbo, partindo da relação sujeito/verbo, objetivando compreender os fatores linguísticos e sociais que condicionam/determinam a variação linguística no âmbito da concordância verbal. Os dados de sua pesquisa foram obtidos a partir de uma amostra da língua falada de uma comunidade periférica da cidade de São Carlos, localizada no interior do estado de São Paulo, Brasil.

No Capítulo 6, Juliana Simões Fonte, doutora em Linguística e Língua Portuguesa pela Faculdade de Ciências e Letras da Unesp de Araraquara, junto com a professora Gladis Massini-Cagliari, da mesma instituição, baseando-se na análise das rimas da poesia remanescente de períodos passados da Língua Portuguesa, demonstram a contribuição de textos poéticos no estudo das vogais do Português Antigo, buscando pistas satisfatórias sobre a pronúncia da época no que diz respeito à diferença de timbre (aberto/fechado) entre as vogais médias tônicas. Serviram de corpora para os estudos das autoras as Cantigas de Santa Maria, de Afonso X, compostas na segunda metade do século XIII, em galego-português, e Os Lusíadas (1572), de Camões.

Fechando o livro, apresentamos, no Capítulo 7, de maneira resumida, os resultados da tese de doutorado de Daniel Soares da Costa. Trata-se de um texto que apresenta uma nova proposta metodológica, baseada em uma conexão entre a música e a linguística atuando como ferramenta para a coleta de dados relativos à prosódia de línguas mortas. Tal metodologia baseia-se na observação das proeminências musicais de textos poéticos musicados, na obser- 
vação das proeminências linguísticas do texto dos poemas, junto com a observação da sua estrutura métrico-poética. Utilizando essa metodologia e um corpus constituído de um recorte das cem primeiras Cantigas de Santa Maria de Afonso X, tomadas a partir das suas versões transcritas por Anglés (1943) para a notação musical atual, o autor faz uma análise da atribuição do acento lexical (e o secundário também) no Português Arcaico, tendo como suporte teórico a Teoria Métrica, na versão de grades parentetizadas de Hayes (1995).

Encerramos esta apresentação ressaltando a importância da dedicação dos pesquisadores no refino e na escolha dos corpora que constituem a base para as suas pesquisas. Um corpus bem delineado e organizado traz informações precisas e muito ricas para os estudos linguísticos, tornando a pesquisa mais pragmática e próxima da realidade linguística, seja ela reflexo de uma realidade linguística atual, como nos estudos sincrônicos sobre línguas vivas, ou reflexo de uma realidade linguística passada, como em estudos de linguística histórica. 


\section{1 \\ O USO ANAFÓRICO DOS PRONOMES DEMONSTRATIVOS NO PORTUGUÊS CONTEMPORÂNEO}

Talita de Cássia Marine ${ }^{1}$

\section{Primeiras palavras}

Diversas pesquisas sociolinguísticas, abordando diferentes níveis da língua (fonológico, sintático, morfológico, lexical, semântico e pragmático), foram e têm sido realizadas no Brasil ao longo, sobretudo, dos últimos trinta anos. Focando seu olhar ora na variedade brasileira, ora na lusitana, ou ainda, em ambas, por meio de estudos comparativos, essas pesquisas têm mostrado que embora haja vários pontos de divergência entre o Português do Brasil (PB) e o Português de Portugal (PP), as semelhanças são muitas.

Coadunando-nos com a noção de que a língua varia e pode mudar ao longo do tempo, visto que sua realidade é dinâmica e multifacetada, em constante "fazimento", tal como propunha Coseriu (1979), neste capítulo serão apresentados parte dos resultados a que cheguei com a realização de minha tese de doutorado (cf. Marine, 2009), parcialmente embasada, cabe destacar, pelos pressupostos teórico-metodológicos do modelo laboviano da Variação e Mudança Linguísticas (Weinreich, Labov, Herzog, 2006; Labov, 1972; 1994; 2002).

1 Professora da Universidade Federal de Uberlândia (UFU). 
Partindo de uma perspectiva sociodiscursiva dos fenômenos da linguagem, neste trabalho apresentarei uma análise descritivo-comparativa do uso anafórico dos pronomes demonstrativos do Português do Brasil (doravante PB) e do Português de Portugal (doravante PP). Para isso, apresentarei os resultados obtidos para as formas demonstrativas variáveis e invariáveis referentes às primeira, segunda e terceira pessoas do discurso: "este/isto", "esse/isso" e "aquele/aquilo", analisadas a partir da observação dos mecanismos de referenciação anafórica tipificados, neste estudo, em cinco diferentes usos: anáfora fiel, infiel, por nomeação, de memória e por elipse.

Tal estudo buscou, sobretudo, verificar se o sistema pronominal do Português se mostra ternário, tal como podemos observar em diversas gramáticas normativas da Língua Portuguesa (cf. Cunha, 1986; Infante, 2002; Cipro Neto e Infante, 2002; Bechara, 2006) ou se, tal como já apontaram alguns estudos a esse respeito (cf. Câmara Jr. 1970; 1975; Castilho, 1978, 1993; Pavani, 1987; Roncarati, 2003; Marine, 2004), mostra-se, na verdade, binário.

\section{Os pronomes demonstrativos}

Segundo descrições de cunho normativo, o sistema dos pronomes demonstrativos da Língua Portuguesa é distribuído da seguinte maneira:

Quadro 1 - Formas variáveis e invariáveis dos pronomes demonstrativos do Português.

\begin{tabular}{|l|c|c|c|c|c|}
\hline \multirow{2}{*}{} & \multicolumn{2}{|c|}{ Variáveis } & Invariáveis \\
\cline { 2 - 6 } & \multicolumn{2}{|c|}{$\begin{array}{c}\text { Masculino } \\
\text { (Singular/Plural) }\end{array}$} & \multicolumn{2}{|c|}{$\begin{array}{c}\text { Feminino } \\
\text { (Singular/Plural) }\end{array}$} & \\
\hline Formas de $1^{\mathrm{a}}$ p. & Este & estes & esta & estas & isto \\
\hline Formas de $2^{\mathrm{a}}$ p. & esse & esses & essa & essas & isso \\
\hline Formas de $3^{\mathrm{a}}$ p. & aquele & aqueles & aquela & aquelas & aquilo \\
\hline
\end{tabular}

Ao pesquisar as definições conferidas aos pronomes demonstrativos por alguns gramáticos do Português, observamos que Cunha 
(1986), Infante (2002), Cipro Neto e Infante (2002) e Bechara (2006) definem os pronomes demonstrativos - de modo geral como aqueles que indicam a posição dos seres em relação às três pessoas do discurso (primeira pessoa: este, esta, isto; segunda pessoa: esse, essa, isso; terceira pessoa: aquele, aquela, aquilo) e acrescentam que essa localização pode se dar no tempo, no espaço ou no discurso. Assim, temos as formas de primeira pessoa marcando referência ao campo do falante, as de segunda, marcando referência ao campo do ouvinte e as de terceira fazendo referência ao que está fora do campo falante-ouvinte.

Vale lembrar que as formas variáveis podem funcionar como pronomes adjetivos (ex.: Este carro é meu) ou substantivos (ex.: Meu carro é este), já as formas invariáveis são sempre pronomes substantivos (ex.: Isso é importante ou Aquilo foi divertido).

Neves (2000), ao discutir a "natureza dos pronomes demonstrativos" em sua "Gramática de usos do Português", classifica os demonstrativos como palavras fóricas, já que sempre fazem referenciação, seja ao contexto, seja à situação do discurso. Vejamos alguns exemplos apresentados por Neves (ibidem, p.491, destaque da autora):

(1) Quando me davam um texto, eu já sabia como ia fazê-lo. Aí, AQUELE texto não me interessava [referência ao contexto].

(2) Eu lhe agradeço a presença nESTA mesa, nESTA ceia [referência à situação do discurso].

Para a pesquisadora, os demonstrativos podem ser empregados como referenciador textual e como referenciador situacional. $\mathrm{Na}$ verdade, o que Neves (ibidem) chama de referenciador textual nada mais é o que em outras gramáticas conhecemos pelo nome de anáfora e catáfora. Já o referenciador situacional é o que mais comumente as gramáticas normativas denominam como referência espaço-temporal ou simplesmente uso dêitico do pronome. Cabe observar que quanto ao uso textual, Infante (2002, p.362), por exemplo, destaca 
que "este" se refere ao que ainda vai ser dito na frase ou texto (catáfora) e "esse", ao que já foi dito (anáfora), tal como podemos observar nos exemplos que seguem abaixo:

(3) Minha palavra final é esta: não!

(4) Para mim o respeito é a base de qualquer tipo de relação inter-pessoal. Essa é a minha opinião.

Já Bechara (2006, p.189), em relação a tal uso, declara que "no discurso, quando o falante deseja fazer menção ao que ele acabou de narrar (anáfora) ou ao que vai narrar (catáfora), emprega este (e flexões)". Para o autor, a forma "esse" só será usada se a referência for feita às palavras da pessoa com quem se fala ou quando for expresso um nome a que, na construção do discurso, se quer juntar uma explicação, comparação, ou se lhe quer salientar alguma característica. Nesses casos, costuma-se repetir o nome (ou o que lhe serve de explicação, comparação ou característica) acompanhado do demonstrativo de segunda pessoa.

Como podemos observar, "as regras" relativas ao sistema dos pronomes demonstrativos em nossa língua estão longe de serem claras. Todas as gramáticas pesquisadas, evidentemente, apresentam características mais detalhadas - umas mais, outras menos - do uso desses pronomes. Tais características nos colocam diante da diversidade e, em alguns casos, das particularidades de emprego dos demonstrativos. Por isso, a fim de tentar compreender melhor o uso desses pronomes, apresentaremos uma breve descrição da maneira como alguns gramáticos "enxergam" o comportamento dos demonstrativos, bem como os apontamentos de alguns linguistas que se dedicaram aos estudos desses pronomes.

\section{O que dizem as gramáticas}

Partindo das relações estabelecidas com as pessoas do discurso (eu/ tu (você)/ ele), Cunha (1986, p.323-4) estabelece as seguintes características gerais para os pronomes demonstrativos: 
1) Este, esta e isto indicam:

a) o que está perto da pessoa que fala;

b) o tempo presente em relação à pessoa que fala.

2) Esse, essa e isso indicam:

a) o que está perto da pessoa a quem se fala;

b) o tempo passado ou futuro com relação à época em que se coloca a pessoa que fala

3) Aquele, aquela e aquilo denotam:

a) o que está afastado tanto da pessoa que fala como da pessoa a quem se fala;

b) um afastamento no tempo de modo vago, ou uma época remota.

Além dessas características gerais, Cunha (ibidem, p.325-6) apresenta alguns "empregos particulares" dos pronomes demonstrativos: 1. Este/ esta/ isto - usados para chamar a atenção sobre aquilo que dissemos ou vamos dizer; 2 . Esse/ essa/ isso - usados tal como este/ esta/ isto - para aludir ao que mencionamos ou para referirmos ao que foi dito por nosso interlocutor; 3. Nisto - usa-se no sentido de "então", "nesse sentido"; 4. Além disso/ isto é/ isto $\mathrm{de} /$ por isso (raramente por isto)/ nem por isso - usados como expressões que se tornaram fixas, devido ao uso. O gramático destaca também que, quando queremos aludir, discriminadamente, a termos já mencionados, usamos "aquele" para o que foi referido em primeiro lugar e, "este" para o que foi nomeado por último:

(5) Caio e Mariana foram viajar. Esta foi para Bahia e aquele para o Rio de Janeiro.

A esse respeito, Neves (2000, p.503) afirma que, se houver mais de um nome antecedente, a referência com "este/isto" seleciona o mais próximo (6), porém observa que não é necessário que o antecedente do "este" anafórico esteja bem próximo dele (7). Por outro lado, se houver mais de um nome antecedente, a referência com "aquele/aquilo" seleciona sempre o mais distante (8): 
(6) Hoje saí para ver umas bolsas. Gostei de uma preta e de uma azul, mas sem dúvida ESTA era muito mais bonita.

(7) O perfil do jovem brasileiro mudou muito. Preocupam-se muito com prazeres individuais e efêmeros e já não cultivam muitos sonhos, tampouco traçam objetivos de vida. ESTAS características assustam cada vez mais a sociedade atual.

(8) A fome e a falta de trabalho são as grandes vilãs da sociedade brasileira e, o pior, caminham sempre juntas. Afinal, com esta como suprir AQUELA?

Cabe ressaltar que Cunha (1986) faz um apontamento acerca dos pronomes demonstrativos bastante curioso e que não foi encontrado por nós em nenhuma outra gramática, exceto por algumas considerações feitas por Neves (2000). De acordo com o autor "os demonstrativos reúnem o sentido de atualização ao de determinação. São verdadeiros 'gestos verbais', acompanhados em geral de entoação particular e, não raro, de gestos físicos” (Cunha, 1986, p.328). Daí a capacidade desses pronomes de fazer aproximar ou distanciar no espaço e no tempo as pessoas e as coisas a que se referem, permitindo-lhes expressar variados matizes afetivos - de admiração, confiança/esperança, indignação, pena/comiseração, malícia, sarcasmo, desprezo -, em especial, os irônicos (ibidem, p.328).

Ainda em suas considerações a respeito dos valores afetivos que podem ser transmitidos pelos pronomes demonstrativos, Cunha (ibidem, p.330) destaca que, quando aplicados a pessoas, os neutros "isto", "isso" e "aquilo" têm, em geral, sentido fortemente depreciativo (como em "Isso não vale nada!", em que "isso" está se referindo, por exemplo, a um homem). Entretanto, "pelos contrastes que não raro se observam nos empregos afetivos, podem esses demonstrativos expressar alto apreço por determinada pessoa" (ibidem, p.330) (como em Aquilo, sim, é que era mulher!).

Neves (2000, p.505) também tece algumas considerações a respeito do valor matizado do demonstrativo para o qual Cunha (1986) nos chama a atenção. A autora afirma que os demonstrati- 
vos, quando usados junto de determinados substantivos abstratos de qualidade, podem estabelecer uma matização irônica, caso se refiram a pessoas. Vejamos um dos exemplos por ela apresentados:

(9) Eu não avisei a ESSA beleza, quando ela chegou, quem era Romeu? Ela se perdeu por gosto.

Outra característica interessante, relativa ao uso dos pronomes demonstrativos, para a qual Cunha (1986, p.324, grifos do original) nos chama a atenção, diz respeito ao fato de que

[...] com frequência, na linguagem animada, nos transportamos pelo pensamento a regiões ou épocas distantes, a fim de nos referirmos a pessoas ou objetos que nos interessam particularmente, como se estivéssemos em sua presença. Linguisticamente, esta aproximação mental traduz-se pelo emprego do pronome este (esta, isto) onde seria de esperar esse ou aquele.

E acrescenta: "ao contrário, uma atitude de desinteresse ou desagrado para com algo que esteja perto de nós pode levar-nos a expressar tal sentimento pelo uso do demonstrativo esse em lugar de este" (ibidem, p.324, grifo do original). A esse respeito, Bechara (2006, p.187) afirma que "na linguagem animada, o interesse do falante pode favorecer uma aproximação figurada, imaginária, de pessoa ou coisa que realmente se acham afastadas dos que falam". Em situações como esta, o autor ressalta que se exige o uso de "este". Por outro lado, afirma que a forma "esse" tem a "missão" de afastar de nós, pessoa ou coisa que se acham ou poderiam achar próximas.

\section{A visão de algumas pesquisas linguísticas}

Rodrigues (1983), ao analisar os pronomes demonstrativos da Língua Portuguesa, uniu as formas variáveis e invariáveis desses pronomes e sugeriu que fossem designados como "ostensivos próximos" e "afastados" do falante e do ouvinte, divididos de maneira 
tripartida: isto, este (s), esta(s) $\Rightarrow$ ostensivos próximos do ouvinte; isso, esse(s), essa(s) $\Rightarrow$ ostensivos próximos do falante e aquilo, aquele(s), aquela(s) $\Rightarrow$ ostensivos afastados do falante e do ouvinte.

Pontes (1978), por meio do recurso à propriedade [+/-animado], propõe que os demonstrativos têm uma forma própria para pessoas e outra para coisas. No entanto, a esse respeito, Rodrigues (1983) afirma que o recurso a essa propriedade não permite suprir adequadamente o sistema dos pronomes demonstrativos do Português, pois segundo a propriedade [+/-animado], as formas variáveis se refeririam às pessoas, as invariáveis, às coisas, mas não haveria nenhuma forma específica usada apenas para os animais. Ou seja, segundo tal propriedade há uma forma para [+animado, +humano] e outra para [-animado, -humano], mas não há uma forma para [+animado, -humano].

Há de se destacar que Câmara Júnior (1970) também já havia atribuído a formas como isto, por exemplo, referência a "coisas" - propriedade [-animado] -, mas, para Rodrigues (1983), esse tipo de atribuição não lhe parece bem fundamentada, pois as formas invariáveis isto, isso e aquilo podem ser, também, perfeitamente aplicadas a seres animados não humanos e humanos, como podemos observar nos exemplos abaixo:

(10) Isto é um peixe.

(11) Aquilo que você vê lá são meninos jogando bola.

De acordo com Rodrigues (1983), a especificação do objeto referido é um dos fatores significativos para uma eficiente análise morfológica dos demonstrativos do Português. De acordo com essa análise, a oposição das formas isto versus este, esta, estes, estas é caracterizada pelos valores da propriedade [+/-especificado], em que teríamos a forma isto atrelada à propriedade [-especificado] e as formas este, esta, estes, estas, à propriedade [+especificado].

Cabe observar que, como já apresentado neste capítulo, segundo Cunha (1986), os demonstrativos têm a capacidade de aproxi- 
mar ou distanciar no tempo e no espaço as pessoas e as coisas a que se referem, permitindo-lhes expressar variados matizes afetivos, como admiração, confiança, indignação, malícia, pena e desprezo. Quando isso ocorre, o uso das formas variáveis e invariáveis pode ocorrer indistintamente na referência a seres animados e inanimados, tal como podemos verificar nos exemplos (12 e 13):

(12) Isso é um monstro! (referindo-se a um homem)

(13) Essa é horrível! (referindo-se a uma casa)

Assim, em concordância com Cunha (1986), acreditamos que não podemos limitar o campo de referência das formas variáveis a seres animados, nem, tampouco, o das formas invariáveis a seres inanimados, como propõem Câmara Júnior (1970) e Pontes (1978). Quanto à proposta de Rodrigues (1983), pela qual os pronomes demonstrativos seriam marcados pela propriedade [+/- especificado], acreditamos que esta seja mais adequada que a de Câmara Júnior (1970) e Pontes (1978); no entanto, quando o uso dos demonstrativos estiver ligado a valores afetivos, isto é, matizados, essa propriedade pode, em determinadas situações enunciativas, não apresentar uma análise compatível com a realidade de uso desses pronomes.

Em (12) - "Isso é um monstro!" , por exemplo, a forma que denominaríamos como [-especificado], ou seja, "isso”, contém maior valor afetivo, no caso, desprezo, contribuindo para melhor expressão do sentido que se quer atribuir a "homem". Numa frase como: "Isso não quer estudar de jeito nenhum", a forma invariável do demonstrativo - referindo-se a um menino - é muito mais expressiva que a forma variável posta na mesma frase: "Esse não quer estudar de jeito nenhum" ou "Esse menino não quer estudar de jeito nenhum”. A esse respeito, Cunha (1986, p.330) afirma que "quando aplicados a pessoas, os neutros isto, isso e aquilo têm, em geral, sentido fortemente depreciativo”.

Cabe destacar que na primeira frase construída com "esse", em que há a elipse do nome "menino", o demonstrativo, depen- 
dendo da situação enunciativa, pode ou não possuir valor afetivo, porém, caso possua, será bem menor que na frase construída com a forma invariável. Já na segunda, o demonstrativo parece funcionar mais como um mero especificador do referente e, portanto, parece, também, atribuir um valor menos matizado em relação àquilo que refere. Diante disso, podemos afirmar que, em determinados contextos de uso, as formas [-especificadas] são muito mais expressivas e precisas do que as formas [+especificadas]. Tais considerações confirmam, cada vez mais, o fato de que não podemos limitar os pronomes demonstrativos a uma análise puramente microlinguística.

Retomando as discussões acerca da divisão tripartida dos pronomes demonstrativos prevista pelas gramáticas normativas da Língua Portuguesa, diferentemente da divisão ostensiva e tripartida proposta por Rodrigues (1983), algumas pesquisas linguísticas apontam para uma simplificação do sistema dos demonstrativos, que de ternário (este/ esse/ aquele) teria passado a binário (este-esse/ aquele) no Português do Brasil (PB).

De acordo com Câmara Júnior (1970), isso se explica devido ao apagamento da distinção entre o campo referencial do ouvinte e o do falante a fim de se criar apenas uma distinção dicotômica entre perto e longe, tal como ocorre no inglês por meio dos pronomes this/ that. Além disso, Câmara Júnior (1970) observa que a distinção fonológica entre este e esse é tão pequena (/st/ : /s/) que acaba promovendo um intercâmbio entre as duas formas na língua coloquial, mesmo em função dêitica, tornando-os gramaticalmente equivalentes.

Segundo o pesquisador, a forma esse predomina sobre este no Rio de Janeiro, o que equivale à mudança de /ste/ para /s/, e acrescenta que "a norma escolar combate essa tendência no sentido de repor o sistema tricotômico, em que esse se circunscreve ao campo do ouvinte; e por ele se pauta a língua escrita e o registro formal da língua oral culta” (ibidem, p.114). Para o estudioso, a relação entre este e esse representa uma "evolução em marcha" na Língua Portuguesa. 
Cabe ressaltar que devido ao fato de "uma língua reluta[r] em regra em abandonar qualquer das suas riquezas expressionais, mesmo quando de maneira geral se afigura excessiva" (idem, 1971, p.331), muitas vezes o "prejuízo expressional" causado pela neutralização no uso das formas este e esse acaba sendo sanado por meio de um novo recurso que procura repor de algum modo o sistema tripartido dos demonstrativos: o uso dos advérbios locativos relacionados às três pessoas do discurso: aqui $\left(1^{\mathrm{a}}\right)$, aí $\left(2^{\mathrm{a}}\right)$ e ali $\left(3^{\mathrm{a}}\right)$. Assim, segundo o autor, por meio desses reforços adverbiais, cria-se um sistema tripartido não mais marcado exclusivamente pelo demonstrativo, mas, sim, pelos advérbios aqui/aí/ali que, inclusive, são advérbios pronominais por terem se originado dos pronomes demonstrativos.

Roncarati (2003), em pesquisa pautada em corpus, apesar de ressaltar que seus dados se restringiram à variedade falada carioca, afirma estar havendo uma reconfiguração paradigmática no sistema dos mostrativos de primeira (este) e segunda (esse) pessoas, pressionando, assim, a implantação de um sistema binário. Os resultados de sua pesquisa apontam para uma elevada produtividade do uso da forma "esse/isso" e para uma ocorrência inexpressiva das formas "este/isto" que, quando usadas, concentram-se em "falantes de mais idade" e em contextos discursivo-pragmáticos específicos, com ênfase e focalização de constituintes, por exemplo.

Outra observação interessante destacada por Roncarati (ibidem, p.157) diz respeito ao "avanço de funções confinadas a casos de referenciação de domínios inferíveis”, ou seja, a casos em que o conhecimento compartilhado entre os falantes é imperativo:

[...] em nossos dados há eloquentes exemplos diante dos quais o recurso ao contexto imediato da situação não preenche satisfatoriamente as condições de identificabilidade dos referentes. Em alguns casos nem mesmo o apelo ao princípio da continuidade referencial resolve o problema da progressão referencial. Nas amostras analisadas, por exemplo, encontramos referentes introduzidos sem continuidade referencial, outros, sem referência prévia, a exigir cálculos inferenciais (ibidem, p.146). 
Cid, Costa e Oliveira (1986 apud Roncarati, 2003), estudando a fala culta dos cariocas com dados do NURC/RJ, constataram que o discurso universitário prioriza "esse" $(91,8 \%)$ em detrimento de "este", reservado a contextos de maior formalidade. Algo semelhante foi constatado por Castilho (1978), ao analisar os pronomes demonstrativos na norma culta de São Paulo (NURC/SP): 60,5\% das ocorrências eram do pronome esse e apenas 39,5\% correspondiam a este. No entanto, de acordo com Castilho (1978, p.31), a "vitória" da forma esse sobre este não pode ser entendida de forma simplista, pois "o esquema binário é substituído pelo ternário assim que o locutor entra em assunto em que se faz necessário especificar melhor a posição de cada coisa".

Em pesquisa posterior e mais recente, no âmbito do projeto "Gramática do Português Falado", Castilho (1993) também encontra a hegemonia da forma "esse": 58\%. Cabe observar que, para essa contagem, o pesquisador incluiu a forma "aquele", a qual respondeu por 29\% das ocorrências, restando a "este", uma frequência de uso de apenas 13\%. Além disso, o autor também confrontou as formas neutras, acrescentando, inclusive, o mostrativo "o"-considerado como demonstrativo na Gramática Tradicional, sempre que é seguido de "de" e "que" -, e constatou que "isto" respondeu por apenas 4\% das ocorrências, enquanto "isso" apareceu em 67\%, "aquilo", 6\% e "o", 23\% dos casos observados.

Pavani (1987, p.85), em sua dissertação de mestrado acerca do uso das formas este, esse e aquele no Português culto falado em São Paulo, afirma ter encontrado "uma alternância entre as formas demonstrativas este e esse, as quais se mostravam gramaticalmente equivalentes", tanto em função anafórica quanto dêitica. Dessa forma, a autora conclui que:

[...] na linguagem oral culta, apesar de serem utilizadas as três formas demonstrativas (este, esse, aquele), há uma tendência a se reduzir o esquema dos demonstrativos de ternário a binário (este/ esse $\mathrm{X}$ aquele). Nossos dados mostram, ainda, uma significativa prevalência de esse sobre este: das 954 ocorrências destas duas for- 
mas demonstrativas, 799 são de esse $(83,75 \%)$ e apenas 155 são de este $(16,25 \%)$. É a vitória de esse sobre este que se prenuncia em nossos dados (ibidem, p.86, grifo do original).

Jungbluth (1998), partindo do pressuposto de que o sistema pronominal dos demonstrativos do $\mathrm{PB}$ está passando por um processo de mudança que o tem levado a uma configuração binária, ao analisar folhetos de poesia de cordel, encontra uma produtividade bastante expressiva da forma "este" e sugere que as pesquisas a respeito de tais pronomes passem a respeitar "os tipos de discurso".

Por outro lado, a autora acredita que o sistema ternário continua sendo usado pelas línguas românicas em função dêitica, especialmente na comunicação face a face, situação em que os oradores e ouvintes estão pessoalmente envolvidos, desenvolvendo a conversação como atividade de junção. Para ela, se havia tradicionalmente um sistema tridimensional em uso, como no latim e no inglês antigo, por exemplo, essa tradição linguística é continuamente praticada, especialmente na fala informal do dia a dia, mesmo se a norma escrita oficial ou em uso formal realmente tiver abandonado o sistema antigo e atualmente apenas faça uso de um sistema bidimensional menos diferenciado (Jungbluth, 1999).

Entretanto, há de se destacar que Coutinho (2005) afirmava que no Latim Vulgar havia uma confusão no uso dos demonstrativos, sendo frequente encontrarmos um empregado em lugar do outro. Nesse sentido, Câmara Júnior (1975) afirma que, provavelmente, o deslocamento de iste foi determinado pelo abandono do demonstrativo de primeira pessoa ( $h i c$ ), fazendo com que iste, demonstrativo de segunda pessoa, passasse a indicar o de primeira. $\mathrm{O}$ autor defende que esse deslocamento tenha sido, a princípio, uma extensão de sua área, para opor o eixo falante-ouvinte a tudo que lhe era exterior (ille). Se foi isso o que aconteceu, o antigo sistema ternário acabou sendo restabelecido por meio da restrição de iste para o campo do falante e pela transferência de "ipse para o campo do ouvinte, propiciada pela presença enfática de ipse junto às três pessoas pronominais, especialmente a segunda" (ibidem, p.103). 
O que percebemos é que enquanto grande parte da România Antiga apresenta vestígios desse sistema, desde cedo é possível notar uma tendência no sentido de se conservar um sistema binário entre os demonstrativos, marcando-se apenas a posição de objeto próximo e objeto remoto em relação ao falante. Portanto, no Latim Vulgar existiam dois demonstrativos de sentido mais definido e persistente - iste e ille - e um terceiro que ocupava uma posição intermediária entre os dois, de "vitalidade mais limitada e, talvez, de sentido um pouco mais vago: ipse” (Maurer, 1959, p.110).

Assim, de acordo com Marine (2004, p.76), podemos descrever as variações sofridas pelo sistema dos pronomes demonstrativos do Latim Clássico $(\mathrm{LC})^{2}$ ao Vulgar (LV) por meio do seguinte esquema:

Esquema 1 - Evolução dos pronomes demonstrativos do Latim Clássico ao Vulgar

Ille (3무 p.)

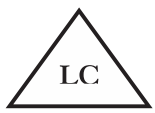

Hic (1ap.)

Iste (2 $\stackrel{a}{p}$.)
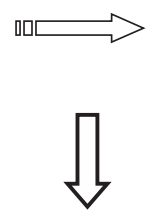

Ille (3무 p.)

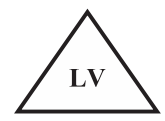

Iste (1ํap.)

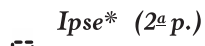

Ille (3무 $p$.

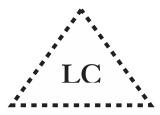

1a $p$. Iste.......... $2^{\underline{a}} p$.

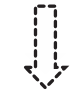

$$
\text { Ille (3a p.) }
$$

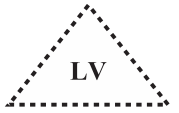

$1 \underline{a} p$

Iste

$2 \underline{a} p$.

* Marcando um sentido menos definido em comparação à relação iste vs. ille.

2 Considerando-o a partir do seu comportamento triádico. 
Esta quarta etapa (em pontilhado, no esquema) apresentada por Marine representa a hipótese da autora segundo a qual, se o ipse marca um sentido menos definido em comparação à relação iste versus ille presente no Latim Clássico, na verdade, a real oposição entre os demonstrativos no Latim Vulgar era, provavelmente, iste versus ille.

Assim, a forma iste no Latim Clássico possivelmente já estava perdendo seu valor referencial relativo à segunda pessoa, o que a teria levado a assumir o lugar de primeira pessoa no Latim Vulgar, ficando ipse para as referenciações de segunda pessoa. Essa possível tentativa de resgatar o sistema ternário não teria se consolidado, de acordo com Marine (ibidem), pelo fato de ipse marcar um sentido menos definido em comparação a iste versus ille. Logo, o verdadeiro uso dos pronomes demonstrativos em Latim Vulgar era iste versus. ille, originado de uma variação do sistema pronominal terciário do Latim Clássico que, no uso, mostrava-se binário.

Ainda segundo Marine (ibidem) em seu estudo diacrônico acerca dos pronomes demonstrativos no PB, desde o Latim Vulgar, o sistema dos demonstrativos mostra-se, de fato, binário. Apesar disso, acrescenta a autora, "a norma da nossa língua insiste na existência de um sistema ternário e, com o apoio das escolas, mantém tal concepção ‘viva', pelo menos do ponto de vista teórico” (ibidem, p.123).

\section{Referência ou referenciação?}

Como já foi exposto na seção introdutória deste capítulo, apresentarei os resultados obtidos em minha tese de doutorado para as formas demonstrativas variáveis e invariáveis ("este/isto", "esse/ isso" e "aquele/aquilo"), analisadas a partir da observação dos mecanismos de referenciação anafórica, segundo algumas tipificações estabelecidas para tal uso. Entretanto, antes de apresentar tal tipificação e os resultados obtidos na referida pesquisa, cabe algumas reflexões acerca da orientação teórica assumida neste estudo quanto às questões referenciais da língua. 
Nesse sentido, há de se destacar que a ideia de que a língua é um sistema de "etiquetas" que se ajustam mais ou menos bem às "coisas” pareceu inquestionável a muitos estudiosos da linguagem por longos anos. Inúmeros quadros conceituais tentaram explicar (e/ ou entender) de que maneira a língua refere o mundo, apoiados nas teorias clássicas da referência, manifestadas por meio das "metáforas do espelho", segundo as quais as estruturas linguísticas refletiriam diretamente as coisas, ou seja, seriam capazes de representar adequadamente a realidade ou o pensamento. "A linguagem, tida como realidade mental, seria um espelhamento do mundo sendo este uma realidade extramental. Daí surgiria a noção de correspondência” (Marcuschi, 2007b, p.105).

Ao negar a ultrapassada "metáfora do espelho", Marcuschi (ibidem, p.108, grifos do original), sugere a "metáfora da lâmpada", já que para ele, a língua, ao invés de ser uma representação especular do mundo,

[... é é uma apresentação; a língua não é um retrato e sim um trato do mundo, isto é, uma forma de agir sobre ele. Mais do que capital, a língua é uma moeda, servindo para trocas; mais do que um almoxarifado de mercadorias disponíveis (num estoque de itens lexicais) a língua é uma carpintaria (uma espécie de heurística). A língua não é uma dupla de trilhos a ligar dois polos - o mundo e a mente -, mas um conjunto de trilhas que decidimos seguir mesmo que dê em aporias.

Essa nova tendência no estudo das questões referenciais, caracterizada pela abordagem sociocognitiva e interacionista da linguagem, é assinalada pela substituição do termo referência por referenciação, tal como apontam Koch, Morato e Bentes (2003, p.8), visto que

[...] passam a ser objeto de análise as atividades de linguagem realizadas por sujeitos históricos e sociais em interação, sujeitos que constroem mundos textuais cujos objetos não espelham fiel- 
mente o "mundo real", mas são, isto sim, interativamente e discursivamente constituídos em meio a práticas sociais, ou seja, são objetos-de-discurso.

Justamente por isso é que Koch e Marcuschi (1998) chamam a atenção para o fato de que o termo "referenciação" substitui a noção mais restrita de "referência" e enfatizam que referir não é um ato de ostensão direta entre linguagem e mundo.

Nesse mesmo sentido, Apothéloz (2003) defende a ideia de que o processo de referenciação não se completa apenas com o emprego de expressões referenciais, já que o referente é criado a partir de um conjunto de ações em que os coenunciadores ajustam suas ações conversacionais e, assim, constroem os sentidos em cada evento. Daí o fato de que a relação "língua-mundo" deixa de ser interpretada apenas por referentes que representam o mundo ou "autorizam" sua representação, passando a assumir uma visão textual-discursiva, interativa e sociocognitiva da referenciação. Assim, "os objetos de discurso não preexistem à atividade cognitiva e interativa dos sujeitos falantes, mas são produtos desta atividade" (Bentes; Rio, 2005a, p.266). Por isso, concordamos com Marcuschi (2007b, p.69), quando tal autor ressalta que a "referenciação é uma atividade criativa e não um simples ato de designação".

\section{A realização anafórica pelos pronomes demonstrativos: considerações teóricas}

Na retórica clássica, o termo anáfora era entendido como a repetição de uma expressão ou de um sintagma no início da frase. Para Milner (2003, p.94), autor que possui uma visão formal sobre os fenômenos de referenciação, "há relação de anáfora entre duas unidades $\mathrm{A}$ e $\mathrm{B}$ quando a interpretação de $\mathrm{B}$ depende crucialmente da existência de A, a ponto de se poder dizer que a unidade B só é interpretável na medida em que ela retoma, inteira ou parcialmente A”. Assim, segundo Milner (ibidem), há anáfora quando há retomada de um antecedente num processo de correferenciação. 
Em Marcuschi (2007b), percebemos que essa visão de anáfora que encontramos em Milner (2003) diz respeito a um tipo específico de anáfora: a anáfora correferencial, que, para Marcuschi (2007b, p.78, grifo do autor), embora seja um fenômeno discursivo, tal como os demais tipos de anáfora,

[... é é uma maneira de pôr o indivíduo num "andador" tirando-lhe a liberdade de criar e obrigando-o a circunstanciar-se ao que vinha em andamento. Pois a anáfora obriga a recobrar algo anterior e tem seus limites nessa operação de recuperação, o que permite entender que as anáforas indiretas seriam algo próximo à dêixis am phantasma de Bühler por irem além dum simples processo de recuperação.

Atualmente, como afirma Marcuschi (2003), o termo "anáfora" é usado para designar expressões que, no texto, reportam-se a outras expressões, enunciados, conteúdos ou contextos textuais-retomando-os ou não -, a fim de contribuir para a continuidade tópica referencial. Quando a referência está ligada a algo que acabou de ser dito, designamos tal referenciação como anafórica, já quando está ligada a algo que será dito em seguida, como catafórica. Cabe ressaltar que conforme Bosch (1983), a adoção do termo "anáfora" foi, de certa forma, uma solução hábil para os problemas causados pelo termo "pronominalização", pois o sentido literal da palavra "pronome" pode levar a interpretações inadequadas, afinal, pronomes são mais do que um substituto para um substantivo ou sintagma nominal que poderia ser utilizado em seu lugar. $\mathrm{O}$ enfoque baseado na substituição também encontra dificuldades para lidar com referências pronominais a entidades do discurso que não foram explicitamente introduzidas ou cujos referentes são passagens inteiras de discurso.

Focando-nos nas referenciações anafóricas realizadas pelos pronomes demonstrativos e seguindo uma orientação sociocognitiva, discursiva e interacionista do fenômeno anafórico, apresentamos alguns tipos de anáfora que foram consideradas em nosso estudo:

I) Anáfora fiel (Apothéloz, 2003) ou Anáfora do tipo I, como prefere Marine (2004): a retomada do antecedente é feita por um 
Sintagma Nominal (SN) (definido) cujo nome nuclear é aquele mesmo por meio do qual foi introduzido. Assim, esse tipo de anáfora é uma das possibilidades de correferência. Exemplo:

(14) Havia uma casa à venda naquela avenida. Esta casa parecia ser bastante confortável.

II) Anáfora infiel (Apothéloz, 2003): o nome da forma de retomada é diferente daquele da forma introduzida (trata-se, mais frequentemente, de um sinônimo ou de um hiperônimo). Marine (2004) afirma que nesse tipo de anáfora, a qual a autora prefere chamar de anáfora do tipo II, a retomada do antecedente é feita pela união "pronome demonstrativo + sinônimo direto ou contextual do nome anteriormente mencionado" e acrescenta que "sinônimos diretos ou contextuais" podem ser realizados de diferentes maneiras, como por meio de sinonímias, hiperonímias, hiponímias e silepses de gênero e/ou número. Exemplos:

(15) A menina adora pipoca. Esta garota come pipoca todos os dias.

(16) As meninas adoram dançar. Essas crianças praticam jazz a tarde toda.

(17) Pelé é conhecido no mundo inteiro. Esse futebolista é exemplo para muitos atletas.

(18) Você pode até não ter pegado esta doença por contato sexual, mas pode transmiti-la por essa via.

III) Anáfora por nomeação (Apothéloz, 2003): quando o sintagma nominal transforma em referente, ou seja, em objeto individuado, o processo denotado por uma proposição anterior; a nomeação pode retomar o conteúdo proposicional da proposição ou o ato de fala realizado por meio da enunciação. Assim, como propõe Marine (2004), focando seu estudo nas anáforas estabelecidas pelos pronomes demonstrativos, nesse tipo de anáfora (anáfora do tipo III) a retomada do antecedente, que nesse caso não constitui apenas 
um nome, mas toda a ideia ${ }^{3}$ pode ser realizada de duas maneiras diferentes: i) "pronome demonstrativo + sinônimo direto ou contextual da proposição anteriormente mencionada" ou ii) "pronome demonstrativo + proposição de mesma referência em relação ao antecedente". Muitas vezes, acrescenta a autora, o uso desse tipo de anáfora implica em um conhecimento compartilhado do assunto/ tema do texto por parte dos interlocutores (escritor/leitor; falante/ ouvinte); caso contrário, ela tende a se tornar incompreensível a um dos interlocutores e, portanto, ineficiente, tanto do ponto de vista textual, quanto do discursivo. É importante ressaltar que a anáfora do tipo III pode ser realizada também pelas formas invariáveis dos pronomes demonstrativos (isto/isso/ aquilo), já que tais pronomes têm a capacidade de estabelecer uma referência textual bastante ampla, podendo retomar toda uma ideia. Observemos os exemplos:

(19) Os arquivos dos jornais serão doados a algumas bibliotecas. Essa doação vai acontecer no fim deste ano.

(20) Todos os sábados eles saem e usam vários tipos de drogas, mas eu não gosto dessas coisas.

(21) Toda vez que ele tem prova na escola, inventa uma nova doença para não ir à escola. Isso não pode mais acontecer.

IV) Anáfora associativa (Apothéloz, 2003): sintagmas nominais definidos que apresentam simultaneamente as seguintes características: i) de um lado, uma certa dependência interpretativa relativamente a um referente anteriormente (às vezes, posteriormente) introduzido ou designado; ii) de outro lado, a ausência de correferência com a expressão que introduziu ou designou anteriormente (às vezes posteriormente) esse referente. Logo, as anáforas associativas apresentam o seu referente - objeto de discurso - como já conhecido (ou identificável), sempre que ele não tiver sido ainda objeto de nenhuma men-

3 O conceito de "ideia" é utilizado por Marine (2004; 2009) de forma bastante abrangente, designando assuntos, proposições, posicionamentos, ações diversas, entre outros. 
ção, e que não indicar mais sua relação com outros referentes ou com outras informações explicitamente formuladas. Um exemplo clássico desse tipo de anáfora, já discutido em vários artigos, é o seguinte:

(22) Nós chegamos a uma cidade. A igreja estava fechada.

Nesse exemplo, o antecedente anafórico, que na verdade é um trigger, ou seja, um "desencadeador”, segundo Hawkins (1977), é o sintagma definido "uma cidade". Já o sintagma definido "a igreja" - que, nesse exemplo, poderia ser também "a farmácia”, "a escola”, "a prefeitura”, entre outros - é o que se denomina, ainda segundo Hawkins, associate, isto é, "associado": sintagma definido cujo emprego como primeira menção de um objeto de discurso (referente) se torna possível graças ao "desencadeador", sem que haja ambiguidade sobre a identidade desse objeto de discurso.

V) Anáfora de memória: partindo do que Apothéloz (2003) define como "dêixis de memória" e do que Bühler (1978 apud Marcuschi, 2007b) define como "dêixis fantasma", propomos um novo tipo de anáfora: a anáfora de memória, que se caracteriza pela retomada do antecedente feita in absentia, ou seja, na ausência de qualquer designação explícita e prévia de seu referente. Nesse caso, a referência é estabelecida pela união "pronome demonstrativo + nome ou ideia resgatada na memória de um dos interlocutores". Cabe ressaltar que esse "resgate" de uma ideia estabelecido pelo escritor/falante deve ser, necessariamente, compartilhado pelo seu leitor/ouvinte, para que a comunicação entre ambos tenha um sentido pleno. Abaixo seguem dois exemplos retirados do corpus que, como poderá ser observado adiante, utilizamos em nossa pesquisa:

(23) Tenho quinze anos e como todas as raparigas da minha idade gosto de homens mais velhos. Há quase um ano conheci uma rapariga que se tornou a minha melhor amiga. Tenho muita ternura por ela, se bem que por vezes pense que sinto algo mais... Sei que a atraio e que ela gosta muito de mim, porém não me atrevo a confessar-lhe que me atrai com medo de perdê-la como amiga. Que posso 
fazer? Laura-Almoçageme/ O melhor é ficares completamente certa do que sentes pela tua amiga. Tem a conta que na adolescência é muito normal viver situações de incerteza ou confusão sexual. Não deves ter medo de manifestar a tua própria maneira de amar; porém, antes de dar um grande passo, assegura-te de que na verdade queres essa pessoa quer seja rapaz ou rapariga. [...]. (Ragazza, fevereiro de 1994).

(24) Para mim, esse negócio de virgindade nunca foi muito importante. Talvez por isso, quando transei pela primeira vez não foi tão emocionante. Mas para uma coisa é ótimo, quebra aquela barreira que a gente sempre coloca na hora de ir além de abraços e beijinhos com os namorados. N.P., 19 anos. (Capricho, abril de 1994).

VI) Anáfora com elipse (Marine, 2004): a retomada do antecedente é feita por meio, exclusivamente, do pronome demonstrativo, visto que o antecedente encontra-se elíptico no sintagma nominal. É importante destacar que esse antecedente elíptico pode ser apenas um nome (25) ou toda uma "ideia" (26), tal como nas anáforas por nomeação.

(25) O primeiro namorado de Maria era muito mulherengo. Ela não teve muita sorte com este, mas dizem que o atual é um rapaz bastante sério. (Ragazza, abril de 1998).

(26) O mais certo é que ele parta do princípio que todas as miúdas gostam que estejam em cima delas constantemente e que ache que essa é a melhor forma de te mostrar o seu carinho e amor. [...]. (Ragazza, abril de 1998).

\section{Estudo variacionista pautado em cartas: justificando o corpus utilizado}

Para iniciar esta seção, é importante destacar que, por coadunarmos com Sinclair (1991), acreditamos que o uso de corpus favorece 
as pesquisas linguísticas, pelo fato de sua utilização proporcionar a realização de descrições linguísticas de base empírica, permitindo, desse modo, a reflexão sobre questões teóricas fundamentadas em usos reais da língua.

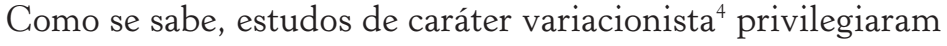
e ainda privilegiam o estudo da modalidade falada da língua em contextos menos formais por acreditar-se que tal modalidade esteja mais vulnerável às variações linguísticas (cf. Faraco, 1991). Entretanto, existem muitos contextos em que a modalidade escrita da língua é marcadamente menos formal que a da fala, constituindo-se, assim, como excelente corpus para estudos variacionistas.

Em relação ao trabalho com esse tipo de texto escrito, Marine (2004; 2009) propõe o conceito de "língua oral-escrita", definido como uma face da linguagem verbal escrita, marcada por traços típicos da fala menos formal, como as cartas das leitoras de algumas revistas femininas, tal como a brasileira Capricho e a portuguesa Ragazza, utilizadas no presente capítulo. Essas revistas, é importante salientar, têm orientações editoriais muito semelhantes; é possível notar que a Ragazza, revista que surgiu em novembro de 2003, baseia-se bastante no estilo da Capricho, cujas primeiras edições datam do fim da década de 1950, embora seu formato atual esteja mais ligado à reformulação pela qual passou a revista em 1989.

Cabe ressaltar um aspecto inestimável desse tipo de carta: segundo Marine (2004; 2009), elas não passam por um processo de edição relacionado à maneira como foram escritas. O que há é o "corte" de alguns fragmentos, visto que geralmente as cartas não são publicadas na íntegra. Por isso, nelas nos vemos diante de um texto escrito profundamente marcado por uma oralidade menos formal, inserido num continuum entre a escrita e a fala que se caracteriza, notoriamente, como um gênero misto, tal como definido por Marcuschi (cf. 2007a). Vejamos os dois exemplos que seguem abaixo, atentando-nos, em especial, para os trechos em destaque:

4 Referimo-nos ao modelo teórico-metodológico da Variação e Mudança Linguísticas proposto por Weinreich, Labov, Herzog, 2006 [1968]; Labov, 1972; 1982; 1994; 2001. 
(27) Uma menina deve contar ao garoto que ela nunca beijou antes? / N.Z.P., 14 anos./ Deve sim. Se ele realmente estiver a fim, não vai fazer diferença se ela nunca beijou antes... não tem aquela história de que o primeiro beijo a gente nunca esquece? Agora, se você ficar sem coragem não conte e nem fique com medo de ele falar alguma coisa, porque essa é uma coisa que não dá pra perceber (...). (Capricho, março de 1994)

(28) Meu namorado, o Maurício, vivia inventando jogos de futebol à noite, jantares inadiáveis. Eu nem sou superciumenta, mas também não consigo ficar achando que isso é normal. Fiquei com a pulga atrás da orelha. Cada vez que aparece uma história dessas eu fico morrendo de ciúme. Não falo nada, mas acabo investigando. Já descobri duas mentiras, e aí rodei a baiana. Ele jurou que nunca mais ia mentir, eu fingi que acreditei e a gente fez as pazes./ Maria Luíza, 17 anos. (Capricho, fevereiro de 1996).

Como pode ser observado, os trechos sublinhados demonstram claramente diversos e diferentes traços de oralidade ${ }^{5}$ e o baixo grau de formalidade desses textos, visto que muitas expressões, marcações discursivas e a própria escolha do léxico são típicas da fala coloquial.

\section{Resultados gerais: "este/isto" e "esse/isso"}

Das 1075 ocorrências dos pronomes demonstrativos variáveis e invariáveis-relativos às primeira e segunda pessoas do discurso de nossa amostra, em uso anafórico, quinhentos são pronomes do Português do Brasil (PB) e 575, do Português de Portugal (PP), segundo a seguinte distribuição:

5 Isto é, marcadores discursivos, segundo Marcuschi (2003), bem como características típicas de conversações menos formais. 
Tabela 1 - Uso anafórico das formas este, isto, esse, isso no $\mathrm{PB}$ e no PP

\begin{tabular}{l|c|c}
\hline & PB & PP \\
\hline Este & $22(4,4 \%)$ & $157(27,3 \%)$ \\
\hline Esse & $247(49,4 \%)$ & $201(35 \%)$ \\
\hline Isto & $2(0,4 \%)$ & $54(9,4 \%)$ \\
\hline Isso & $229(45,8 \%)$ & $163(28,3 \%)$ \\
\hline Total & $500(100 \%)$ & $575(100 \%)$ \\
\hline
\end{tabular}

É possível observarmos que tanto nas formas variáveis quanto nas invariáveis, os demonstrativos de segunda pessoa predominam em relação às formas de primeira pessoa: temos 476 ocorrências de "esse/isso" no PB e apenas 24 de "este/isto". Isso significa que no uso anafórico do PB, "esse/isso" respondem por 95,2\% das ocorrências. No PP, temos 364 ocorrências de "esse/isso" e 211 de "este/ isto". Ou seja, embora de modo menos patente que no PB, as formas de segunda pessoa também predominam no uso anafórico da amostra do PP, já que "esse/isso" correspondem a 63,3\% das ocorrências.

\section{Os usos de "este/esse" e "isto/isso" segundo os tipos anafóricos}

Separando os dados de acordo com os cinco tipos de anáfora que observamos em nosso corpus, chegamos aos seguintes dados:

Tabela 2 - Distribuição dos demonstrativos segundo a tipificação anafórica no PB e no PP

\begin{tabular}{l|c|c|c|c|c|c|c|c}
\hline & \multicolumn{2}{|c|}{ PB } & \multicolumn{2}{c|}{ PP } & \multicolumn{2}{c|}{ PB } & \multicolumn{2}{c}{ PP } \\
\cline { 2 - 11 } & Este & Esse & Este & Esse & Isto & Isso & Isto & Isso \\
\hline Ana. Fiel & 2 & 27 & 9 & 39 & - & - & - & - \\
\hline Ana. Infiel & 6 & 36 & 21 & 34 & - & - & - & - \\
\hline Ana./ Nomeação & 6 & 104 & 101 & 114 & 1 & 223 & 53 & 162 \\
\hline Ana./ Memória & 4 & 46 & 2 & 5 & - & 6 & - & - \\
\hline Ana/ Elipse & 5 & 34 & 25 & 10 & - & - & - & - \\
\hline Total: 1075 & 23 & 247 & 158 & 202 & 1 & 229 & 53 & 162 \\
\hline
\end{tabular}


Observando os dados acima, todos em números absolutos, percebemos que, à exceção da anáfora por nomeação, os pronomes demonstrativos em uso anafórico são mais expressivos nas formas variáveis do que nas invariáveis. É interessante notar também que tanto as anáforas fiéis quanto as infiéis só podem se realizar pelas formas variáveis visto que, necessariamente, só ocorrem em função adjetiva, ou seja, como determinantes; ambas, nas duas variedades do Português, mostraram-se mais expressivas no uso de "esse": 93\% de ocorrências de anáforas fiéis no PB e 81\% no PP e, 86\% de ocorrências no PB e 62\% no PP de anáforas infiéis.

Já as anáforas por nomeação, percebemos que são bastante produtivas tanto nas formas variáveis quanto nas invariáveis nas duas variedades da língua, com predominância das formas de segunda pessoa. No entanto, no PP não identificamos uma expressão tão patente das formas de segunda pessoa como a observada no PB; nessa variedade do Português, temos quase 95\% de frequência de uso de "esse" e praticamente 100\% de "isso".

No PP, embora as 430 ocorrências de anáfora por nomeação se encontrem exatamente divididas em 215 ocorrências de formas variáveis e 215 de formas invariáveis, percentualmente só é possível identificar um uso mais equilibrado entre os demonstrativos variáveis: temos 53\% de ocorrências com "esse" e 47\% com "este". Já entre os invariáveis, verificamos 75,3\% de ocorrências com "isso" e apenas $24,7 \%$ com "isto".

Quanto às anáforas de memória, percebemos que não foram muito produtivas no $\mathrm{PB}$ (cerca de 10\%) e nem no PP (apenas 2\%). $\mathrm{E}$, por fim, em relação às anáforas por elipse, no $\mathrm{PB}$ se privilegia a forma "esse" com uma frequência que beira os 90\%. No PP também identificamos uma percentual expressivo: quase 72\%. Acreditamos que, nesse caso, a predominância do demonstrativo "esse" esteja relacionada ao fato de que o que está elíptico na maioria dessas anáforas é, justamente, uma anáfora por nomeação, ou seja, não apenas um "nome", mas toda uma ideia anteriormente apresentada. E, como a forma predominante nas anáforas por nomeação é o 
pronome demonstrativo relativo à segunda pessoa, logo, as anáforas por elipse, quando "escondem" uma anáfora por nomeação, tendem, também, a privilegiar o demonstrativo "esse". Vejamos um exemplo:

(29) [...]. Embora possas pensar isso, a tua decisão não se baseou exclusivamente no facto de o veres a beijar um homem, pois há diferentes maneiras de enfrentar uma situação tão complicada quanto essa. [...]. (Ragazza, setembro de 1995).

Além de tipificarmos o uso anafórico dos pronomes demonstrativos, dividimo-lo segundo as funções adjetiva e substantiva, tal como apresentamos na seguinte tabela:

Tabela 3 - Função adjetiva e substantiva das formas anafóricas este, isto, esse, isso no $\mathrm{PB}$ e no PP

\begin{tabular}{l|c|c|c|c}
\hline \multirow{2}{*}{} & \multicolumn{2}{|c|}{ PB } & \multicolumn{2}{c}{ PP } \\
\cline { 2 - 5 } & Determinante & Pronome & Determinante & Pronome \\
\hline Este/ Isto & 22 & 2 & 134 & 77 \\
\hline Esse/ Isso & 247 & 229 & 196 & 168 \\
\hline Total & 269 & 231 & 330 & 245 \\
\hline
\end{tabular}

Das quinhentas ocorrências de uso anafórico no $\mathrm{PB}$, temos $53,8 \%$ na função adjetiva, e 46,2\% na função substantiva; no PP, $57,4 \%$ estão relacionadas à função substantiva e, 42,6\% à função substantiva, o que evidencia o quanto essas funções em usos anafóricos são bastante produtivas entre os pronomes demonstrativos nas duas variedades do Português.

Para aprofundarmos mais a análise de nossos dados, verificamos as ocorrências dos pronomes demonstrativos "este/isto" e "esse/isso" de acordo com os tipos de anáfora abordadas em nosso estudo, considerando as funções adjetiva e substantiva, respectivamente. Vejamos: 
Tabela 4 - Distribuição anafórica das formas este, isto, esse, isso no PB e no PP em função adjetiva

\begin{tabular}{|c|c|c|c|c|}
\hline & \multicolumn{2}{|c|}{ PB } & \multicolumn{2}{|c|}{ PP } \\
\hline & Este/Isto & Esse/Isso & Este/Isto & Esse/Isso \\
\hline Anáfora fiel & $2(7 \%)$ & $27(\mathbf{9 3} \%)$ & $9(18 \%)$ & $42(82 \%)$ \\
\hline Anáfora infiel & $6(14 \%)$ & $36(86 \%)$ & $23(41 \%)$ & $33(59 \%)$ \\
\hline Anáfora por nomeação & $6(\mathbf{5 , 5} \%)$ & $104(\mathbf{9 4 , 5 \% )}$ & $102(47 \%)$ & $113(\mathbf{5 3} \%)$ \\
\hline Anáfora de memória & $4(8 \%)$ & $46(92 \%)$ & $4(33 \%)$ & $8(67 \%)$ \\
\hline Anáfora por elipse & $4(10,5 \%)$ & $34(\mathbf{8 9 , 5 \% )}$ & $1(33 \%)$ & $2(67 \%)$ \\
\hline Total geral & $22(8,2 \%)$ & $247(\mathbf{9 1 , 8 \% )}$ & $139(\mathbf{4 1 , 3 \% )}$ & $198(\mathbf{5 8 , 7 \%})$ \\
\hline
\end{tabular}

Os dados acima demonstram de modo evidente que as formas "esse/isso" são muito mais utilizadas que suas concorrentes "este/ isto”, sobretudo no PB, já que temos quase 92\% de frequência de uso das formas demonstrativas anafóricas de segunda pessoa, em função adjetiva. No PP, a predominância das formas "esse/isso" beira aos 60\%.

Já na Tabela 5, podemos observar a ocorrência das formas demonstrativas de primeira e segunda pessoas do discurso, segundo a função substantiva, em cada tipo de anáfora:

Tabela 5 - Distribuição anafórica das formas "este, isto, esse, isso no PB e no PP em função substantiva

\begin{tabular}{l|c|c|c|c}
\hline \multirow{2}{*}{} & \multicolumn{2}{|c|}{ PB } & \multicolumn{2}{c}{ PP } \\
\cline { 2 - 5 } & Este/Isto & Esse/Isso & Este/Isto & Esse/Isso \\
\hline Anáfora fiel & - & - & - & - \\
\hline Anáfora infiel & - & - & - & - \\
\hline Anáfora por nomeação & $1(\mathbf{0 , 5} \%)$ & $223(\mathbf{9 9 , 5 \% )}$ & $54(\mathbf{2 4} \%)$ & $170(\mathbf{7 6} \%)$ \\
\hline Anáfora de memória & - & $6(\mathbf{1 0 0} \%)$ & $2(\mathbf{3 3} \%)$ & $1(\mathbf{6 7 \% )}$ \\
\hline Anáfora por elipse & $1(\mathbf{1 0 0} \%)$ & - & $25(\mathbf{7 8} \%)$ & $7(\mathbf{2 2} \%)$ \\
\hline Total geral & $2(\mathbf{1 0 0} \%)$ & $229(\mathbf{1 0 0} \%)$ & $81(\mathbf{1 0 0} \%)$ & $178(\mathbf{1 0 0} \%)$ \\
\hline
\end{tabular}

Analisando a Tabela 5, percebe-se que é nulo o uso pronominal dos demonstrativos nas anáforas fiel e infiel na variedade portuguesa e brasileira do Português, afinal, tais anáforas só podem se 
realizar na função adjetiva. Todavia, cabe ressaltar que as anáforas fiéis podem estar "escondidas" (elípticas) na forma de anáforas por elipse, tal como as anáforas por nomeação, como já mencionamos anteriormente e que, inclusive, são as que mais comumente estão associadas com as por elipse. Ilustramos, abaixo, um exemplo em que a anáfora por elipse está "escondendo" uma anáfora fiel:

(30) A-do-rei o baú de coisas maravilhosas do "Capricho escolheu" - Capricho, dezembro - para o ano que vem. Tomara que todos esses desejos se realizem, pois esses que vocês escolheram eu não tiro nem um acento. Luísa N. Serralvo, 15 anos. (Capricho, fevereiro de 1996).

Já na anáfora por nomeação, observamos grande produtividade dos demonstrativos em função substantiva e, nesse caso também, com uma frequência de uso muito maior das formas "esse/isso": praticamente $100 \%$ dos usos no $\mathrm{PB}$ - 223 ocorrências de um total de 224 - e 76\% no PP - 170 de um total de 224 ocorrências.

Nossos dados demonstram, cada vez de modo mais evidente, que as formas "esse/isso" têm se mostrado muito mais produtivas que suas concorrentes "este/isto" em ambas as variedades do Português, ao menos em nosso corpus. Também apontam para o fato de que a predileção pelo uso de "esse/isso" na função anafórica está mais fortemente marcada no PB.

Quanto ao uso pronominal da anáfora de memória em função substantiva, percebemos um uso "tímido" em nossos dados, em ambas as variedades do Português, já que, em nosso corpus, tal anáfora é muito expressiva na função adjetiva, tal como já pudemos observar. No PB, as seis ocorrências de anáfora de memória ocorrem por meio de "esse/isso" e, no PP, temos uma ocorrência de "esse/isso" e duas de "este/isto". Em seguida, apresentamos dois exemplos:

(31) Essa é a loja da Capricho, mas não tem a camiseta. Dá pra quebrar ESSA?/ Karen e Raquel Schneider, 12 e 13 anos. (Capricho, agosto de 1994). 
(32) [...]. Lembra-te que por muito difícil que seja, não há ninguém inconquistável; se embarcares nesta, pisa com segurança no acelerador e verás como cairá na tua rede! (Ragazza, novembro de 1995).

Por fim, algo que nos chamou bastante a atenção diz respeito ao uso pronominal das anáforas por elipse no PP, visto que nesse tipo anafórico, diferentemente dos demais, o uso pronominal dos demonstrativos foi marcado pela predominância das formas "este/ isto". ${ }^{6}$ Como pode ser observado na Tabela 5, das 32 ocorrências de anáforas por elipse em função substantiva, 25, ou seja, 78\% dos dados se realizaram por meio das formas "este/isto".

\section{Os usos de "aquele" e "aquilo" no PB e no PP}

Em relação aos pronomes demonstrativos relativos à terceira pessoa em uso anafórico, nossa amostra foi composta por 58 ocorrências no $\mathrm{PB}$ e 93 no PP, as quais foram analisadas de acordo com a mesma distribuição tipológica que utilizamos para a análise dos demonstrativos variáveis e invariáveis de primeira e segunda pessoas. Na Tabela 6, apresentamos essa distribuição:

Tabela 6 - Distribuição das formas "aquele" e "aquilo", segundo a tipificação anafórica.

\begin{tabular}{l|c|c|c|c}
\hline \multirow{2}{*}{} & \multicolumn{2}{|c|}{ PB } & \multicolumn{2}{c}{ PP } \\
\cline { 2 - 5 } & Aquele & Aquilo & Aquele & Aquilo \\
\hline Anáfora fiel & $2(\mathbf{1 0 0} \%)$ & - & $4(\mathbf{1 0 0} \%)$ & - \\
\hline Anáfora infiel & $3(\mathbf{1 0 0} \%)$ & - & $5(\mathbf{1 0 0} \%)$ & - \\
\hline Anáfora por nomeação & $1(\mathbf{1 2 , 5 \% )}$ & $7(\mathbf{8 7 , 5 \% )}$ & $14(\mathbf{3 0 , 5} \%)$ & $32(\mathbf{6 9 , 5 \% )}$ \\
\hline Anáfora de memória & $28(\mathbf{8 7 , 5 \%})$ & $4(\mathbf{1 2 , 5 \% )}$ & $10(\mathbf{3 7 \%})$ & $17(\mathbf{6 3} \%)$ \\
\hline Anáfora por elipse & $13(\mathbf{1 0 0} \%)$ & - & $11(\mathbf{1 0 0} \%)$ & - \\
\hline
\end{tabular}

6 Os dados do PB, neste caso, não são significativos, já que constatamos apenas uma ocorrência. 
Como podemos observar, as anáforas fiéis e infiéis não foram muito produtivas em nosso corpus, representando apenas $8,6 \%$ das ocorrências no PB, e 9,7\% no PP. Com isso, percebemos que tais tipos anafóricos estão mais vinculados aos usos das formas de primeira e segunda pessoas, visto que, tal como pode ser verificado na Tabela 6 , as anáforas fiéis e infiéis realizadas com as formas de primeira e segunda pessoas, corresponderam a 14,2\% dos usos anafóricos no $\mathrm{PB}$ e 18\% no PP. Todavia, é notório que, de modo geral, esses dois tipos anafóricos não se mostraram muito produtivos em nosso corpus.

Já a anáfora por elipse apresentou uma frequência de uso um pouco maior: 22,4\% no $\mathrm{PB}$ e 15\% no $\mathrm{PP}$ e, nessas anáforas, percebemos que estão "escondidas" - assim como ocorre nas referenciações por elipse com as formas de primeira e segunda pessoas - anáforas fiéis e anáforas de memória, porém não registramos nenhum caso em que a anáfora por elipse estivesse "escondendo" uma anáfora por nomeação. Isso nos parece muito interessante, pois, quando analisamos as formas de primeira e segunda pessoas, constatamos que, nas anáforas por elipse, o termo elíptico, na maioria das ocorrências, era, justamente, uma anáfora por nomeação.

Quanto à anáfora por nomeação, identificamos uma frequência de uso de quase $14 \%$ no PB e de $49 \%$ no PP. Nas duas variedades da língua, percebemos que tal tipo anafórico, costuma ser mais produtivo com as formas invariáveis, sobretudo no $\mathrm{PB}$, no qual constamos 87,5\% de "aquilo" nas anáforas por nomeação. No PP, a predominância de "aquilo" foi de 69,5\%.

Comparando esses resultados com os que obtivemos em relação às formas variáveis e invariáveis dos demonstrativos de primeira e segunda pessoas, verificamos que no $\mathrm{PB}$ as anáforas por nomeação realizadas com "este", “isto", "esse" e "isso" tendem a se realizar com as formas invariáveis - $67 \%$ das ocorrências -, tal como constatamos para as formas demonstrativas de terceira pessoa. Já no $\mathrm{PP}$, diferentemente da supremacia constatada para as formas invariáveis de terceira pessoa, há um equilíbrio de usos entre as formas variáveis e invariáveis de primeira e segunda pessoas: $50 \%$ de frequência para cada uma delas. 
Em relação às anáforas de memória, percebemos que elas compuseram o tipo anafórico mais produtivo entre os pronomes demonstrativos de terceira pessoa em nosso corpus, chegando a representar 55\% das ocorrências anafóricas do PB e 29\%, no PP. Esses resultados nos chamaram a atenção, principalmente pelo fato de a anáfora de memória ter tido pouco expressividade nas formas demonstrativas de primeira e segunda pessoas, conforme já descrito. Parece-nos, então, que a realização desse tipo anafórico está relacionada com a escolha do pronome demonstrativo que, no caso, realiza-se predominantemente com "aquele" no $\mathrm{PB}-87,5 \%$ das ocorrências - e com "aquilo” no PP - 63\%.

A princípio, quando tínhamos realizado apenas as análises das formas demonstrativas de primeira e segunda pessoas, achamos "estranha" a baixa incidência desse tipo de anáfora, dada a natureza de nosso corpus, cujo conhecimento compartilhado entre as leitoras e a revistas é marcante. Dada a relação de amizade por elas construída, nossa expectativa era a de que tal anáfora tivesse se mostrado com destaque em nosso corpus. Entretanto, as formas de terceira pessoa vieram confirmar nossa expectativa e, mais do que isso, chamar-nos a atenção para a necessidade de se estudar as três formas demonstrativas que compõem o sistema pronominal dos demonstrativos, percebendo que, ao desempenhar as mesmas funções referenciais que "este/isto" e "esse/isso", existem situações discursivas em que as formas de terceira pessoa competem com as de primeira e segunda e outras nas quais são protagonistas. Da mesma forma, existem situações discursivas cuja referenciação é protagonizada ora por "este/isto", ora por "esse/isso".

\section{Considerações finais}

No âmbito da abordagem do que entendemos como "língua" ou seja, uma realidade dinâmica e multifacetada, que não preexiste, mas, sim, que se realiza em situações concretas de uso e teoricamente amparada por uma visão sociodiscursiva e interacionista da 
linguagem -, neste capítulo analisamos as relações de referenciação anafórica estabelecidas pelos pronomes demonstrativos "este/ esse", "isto/isso" e "aquele/aquilo" a partir de uma amostra de dados composta por cartas de leitoras de duas revistas femininas - a brasileira, Capricho, e a portuguesa, Ragazza - no período que vai de 1994 a 2005.

Tal estudo buscou, sobretudo, verificar se o sistema pronominal do Português se mostra ternário - considerando, por ora, apenas o seu uso anafórico -, tal como podemos observar em diversas gramáticas normativas da Língua Portuguesa, ou se, como já apontaram alguns estudos a esse respeito (cf. Câmara Jr. 1970; 1975; Castilho, 1978; 1993; Pavani, 1987; Roncarati, 2003; Marine, 2004), mostra-se, na verdade, binário. E, considerando os resultados obtidos em nossa análise, podemos afirmar que o sistema pronominal do PB está se portando de modo binário, já que as formas "esse/isso" apresentaram uma frequência de $95 \%$ de uso no PB.

Quanto ao PP, visto que o percentual de frequência de "este" foi relativamente "robusto" em nossa amostra, acreditamos que o sistema dos pronomes demonstrativos nessa variedade do Português está passando por um processo de variação, em que o esquema ternário tende a dar espaço a um sistema binário, tal como no PB.

Cabe observar que, sobretudo na língua escrita mais formal, tanto em Portugal como no Brasil, tenta-se preservar a distinção entre "este" e "esse" para referências dentro de um dado contexto linguístico; porém, a regra que se criou para manter essa distinção, além de se mostrar divergente em algumas gramáticas (cf. Infante, 2002, p.363; Bechara, 2006, p.188-9), apresenta-se como uma convenção subjetiva, fora da realidade linguística e que não é seguida com rigor. É por isso que quando observamos o uso real desses pronomes em textos escritos menos formais, percebemos de modo bastante claro um binarismo no PB e uma transição (variação) no $\mathrm{PP}$, que de ternário tende a se tornar binário tal qual no Brasil.

Acreditamos, inclusive - pautando-nos na revisão teórica acerca dos demonstrativos somada aos resultados de diversas pesquisas linguísticas, sobretudo aos de nosso estudo -, que o uso binário dos 
pronomes demonstrativos se mostra bastante produtivo há tempos em nossa língua, característica que, provavelmente, herdamos do Latim.

\section{Referências bibliográficas}

APOTHÉLOZ, D. Papel e funcionamento da anáfora na dinâmica textual. In: CAVALCANTE, M. M.; RODRIGUES, B. B.; CIULLA, A. (orgs.). Referenciação. São Paulo: Contexto, 2003. p.53-84.

BECHARA, E. Moderna gramática portuguesa. 37. ed. rev. e ampl. Rio de Janeiro: Lucerna, 2006.

BENTES, A. C.; RIO, V.C. A construção conjunta da referência em uma entrevista semimonitorada com jovens universitários. In: BENTES, A. C., KOCH, I. V.; MORATO, E. M. (orgs.). Referenciação e discurso. São Paulo: Contexto, 2005a.

BENTES, A. C. \& RIO, V. C. Introdução. In: BENTES, A. C., KOCH, I. V. \& MORATO, E. M. (orgs.) Referenciação e discurso. São Paulo: Contexto, 2005b.

BOSCH, P. Agreement and Anaphora. A Study of the Role of Pronouns in Syntaxe and Discourse. Londres: Academic Press, 1983.

CÂMARA JR., J. M. Estrutura da Lingua Portuguesa. Petrópolis: Vozes, 1970.

. História e estrutura da Língua Portuguesa. Rio de Janeiro: Padrão, 1975.

CASTILHO, A. T. de. Análise preliminar dos demonstrativos na norma culta de São Paulo. Anais de Seminários do GEL, 1978. p.30-35.

Os mostrativos do português falado. In: Gramática do Português Falado. As abordagens, vol. 3. Campinas, , 1993. p.119-45.

CIPRO NETO, P.; INFANTE, U. Gramática da Língua Portuguesa. São Paulo: Scipione, 2002.

COSERIU, E. Sincronia, diacronia e história: o problema da mudança lingüística. Tradução de Carlos Alberto da Fonseca e Mário Ferreira. Rio de Janeiro; São Paulo: Presença; EDUSP, 1979.

COUTINHO, I. L. Gramática histórica. 19. ed. Rio de Janeiro: Editora ao Livro Técnico, 2005.

CUNHA, C. Gramática da língua portuguesa. Rio de Janeiro: Feriame, 1986. 
FARACO, C. A. Lingüística histórica. São Paulo: Ática, 1991.

INFANTE, U. Curso de Gramática aplicada aos textos. São Paulo: Scipione, 2002.

JUNGBLUTH, K. O uso dos demonstrativos em textos semi-orais: o caso dos folhetos nordestinos do Brasil. In: GROBE, S.; ZIMMERMANN, K. (eds.). "Substandard” e mudança no português do Brasil. Frankfurt: TFM, 1998. p. 328-55.

JUNGBLUTH, K. Two and three-dimensional deitic systems between speech and writing: Evidences from the use of demonstratives in romanes languages. 1999. Disponível em: http:// www.lili.uni-bielefeld. de/ deixis/rader/node15.html. Acesso em: 13 dez. 2002.

KOCH, I. G. V.; MARCUSCHI, L. A. Processos de referenciação na produção discursiva. D.E.L.T.A., v. 14 (número especial), 1998. p.169-90.

KOCH, I. G. V.; MORATO, E. M.; BENTES, A. C. Referenciação e discurso. São Paulo: Contexto, 2003.

LABOV, W. Sociolinguistic patterns. Philadelphia; University of Pennsylvania Press, 1972.

LABOV, W. Building on Empirical Foundations. In: LEHMANN, W.; MALKIEL,Y.(Ed.) Perspectives on Historical Linguistics. Masterdam/ Philadelphia: John Benjamins Publishing Company, 1982. p.17-92.

LABOV, W. Principles of linguistic change. vol. 1: internal factors. Cambridge, Massachusetts, Oxford: Blackwell Publishers, 1994.

LABOV, W. Principles of linguistic change. vol. 2: social factors. Massachusetts, Oxford: Blackwell Publishers, 2002.

MARCUSCHI, L. A. Análise da conversação. 5.ed. São Paulo: Ática, 2003. (Série Princípios).

Da fala para a escrita: atividades de retextualização. 8. ed. São Paulo: Cortez, 2007a.

. Cognição, linguagem e práticas interacionais. 1. ed. Rio de Janeiro: Lucerna, 2007b.

MARINE, T. C. O binarismo dos pronomes demonstrativos no século XX: este vs. aquele ou esse vs. aquele? Araraquara, 2004. $138 \mathrm{fls}$. Dissertação (Mestrado em Linguística e Língua Portuguesa) - Faculdade de Ciências e Letras, Unesp, Araraquara, 2004.

. Um estudo sócio-discursivo do sistema pronominal dos demonstrativos no português contemporâneo. Araraquara, 2009. 220 fls. Tese (Doutorado em Linguística e Língua Portuguesa) - Faculdade de Ciências e Letras, Unesp, Araraquara, 2009. 
MAURER, T. H. J. Gramática do latim vulgar. Rio de Janeiro: Liv. Acadêmica, 1959.

MILNER, J. Reflexões sobre a referência e a correferência. In: CAVALCANTE, M.M. et alii (orgs.). Referenciação. São Paulo: Contexto, 2003.

NEVES, M. H. M. Gramática de usos do português. São Paulo: Editora Unesp, 2000.

PAVANI, S. Os demonstrativos este, esse e aquele no português culto de São Paulo. Campinas, 1987. 90 fls. Dissertação (Mestrado em Linguística) - Instituto de Estudos da Linguagem, Universidade de Campinas, Campinas, 1986.

PONTES, E. O "Continuum" língua oral e língua escrita: por uma nova concepção do ensino. Trab. Ling. Apl. Campinas, n.12, p.101-7, jul./ dez. 1978.

RODRIGUES, A. D. Os demonstrativos do português: descrição morfológica sincrônica e superficial. VII Anais de Seminários do GEL, p.646, Mogi das Cruzes, 1978.

RONCARATI, C. Os mostrativos na variedade carioca falada. In: PAIVA, M. da C.; DUARTE, M. E. L. (orgs.). Mudança lingúística em tempo real. Rio de Janeiro: Contra Capa Liv., 2003.

SINCLAIR, J. Corpus, Concordance, Collocation. Oxford: Oxford University Press, 1991.

WEINREICH, U.; LABOV, W.; HERZOG, M. Fundamentos empíricos para uma teoria da mudança lingüística. São Paulo: Parábola, 2006. 


\section{2 \\ UMA ANÁLISE \\ SÓCIO-HISTÓRICO-LINGUÍSTICA \\ DA POSIÇÃO DOS CLÍTICOS PRONOMINAIS EM TEXTOS JORNALÍSTICOS PAULISTANOS $(1880-1920)^{1}$}

Caroline Carnielli Biazolli²

\section{Introdução}

O presente estudo, sob a perspectiva da Sociolinguística Variacionista e da Linguística Histórica, debruçou-se sobre o estudo da posição dos pronomes clíticos, utilizando-se, como matriz das análises, produções jornalísticas elaboradas no final do século XIX e início do século XX, particularmente entre os anos de 1880 a 1920, e oriundas da cidade de São Paulo. Observou-se o comportamento desses pronomes, em contextos de um ou mais de um verbo - sabe-se que, adjuntos a um único verbo, os pronomes átonos podem ocupar as posições proclítica, mesoclítica ou enclítica e, adjungidos a um complexo verbal, podem se alternar nas posições pré-complexo verbal (cl V1 V2), intracomplexo verbal (V1 cl V2) ou pós-complexo verbal (V1 V2 cl) -, a fim de que se permitisse, além de contribuir com a

1 Este capítulo contempla algumas das questões discutidas em Biazolli (2010) - dissertação de mestrado, defendida em 2010, na Universidade Estadual Paulista "Júlio de Mesquita Filho" (Unesp), campus de Araraquara, sob a orientação da professora Rosane de Andrade Berlinck e financiada pela Fundação de Amparo à Pesquisa do Estado de São Paulo (Fapesp) (Processo 08/51935-1).

2 Doutoranda do Programa de Pós-Graduação em Linguística e Língua Portuguesa da Faculdade de Ciências e Letras da Unesp, campus de Araraquara. 
descrição da história do Português Brasileiro (doravante PB) e da variedade paulista, averiguar as preferências de colocação, modificadas, consoante outras pesquisas apontam, num curto intervalo de tempo.

Baseado na proposta teórico-metodológica da Teoria da Variação e Mudança Linguísticas (Weinreich; Labov; Herzog, 2006 [1968]; Labov, 1982; 1994; 2001; 2008 [1972]), este estudo considerou fundamental um levantamento dos possíveis elementos condicionadores, extralinguísticos e linguísticos, que estivessem, desde o período observado, a controlar os usos alternados da colocação dos clíticos pronominais. Inseriu-se, no âmbito dos aspectos extralinguísticos elencados, considerações pertinentes acerca dos gêneros textuais, remetendo-se, assim, a pesquisa em questão, também a conceitos referentes a essa esfera de reflexão.

A opção por um estudo que se concentrasse na análise de um material linguístico produzido nos últimos anos do século XIX e nos primórdios do século XX se justificou, por um lado - seguindo a concepção de que linguagem e sociedade ou, mais precisamente, língua, cultura e sociedade estão relacionadas -, pelos relevantes acontecimentos sociais, culturais, históricos e políticos que marcaram, naquela época, o plano nacional e inclusive a cidade e o estado de São Paulo; e, por outro, pela importância em se verificar a nítida predominância, em relação a um só verbo, da ênclise no século XIX, sendo substituída, no século XX, pela próclise - tida como a forma mais produtiva do $\mathrm{PB}$ atual -, e o caráter inovador do $\mathrm{PB}$, quanto aos complexos verbais, no século XX, com a próclise ao segundo verbo - aspectos já destacados em outros relevantes trabalhos.

Embora se tenha reconhecido a tendência conservadora da linguagem escrita, assinalando influências, mesmo que discretas, da modalidade falada na modalidade escrita, esperava-se, no período selecionado, encontrar dados que apontassem uma convivência relevante entre as diferentes colocações dos pronomes átonos - inclusive, usos que fossem de encontro às prescrições da norma-padrão vigente naquela época, revelando traços próprios do PB. Isso porque o material utilizado, os jornais, pode concentrar, através da linguagem, o que há de maior prestígio sociocultural. E, também, 
porque, pelo seu dinamismo e pela necessidade de criar certa identidade com o leitor (a ponto de refletir, aceitar e incorporar o uso que ele faz), possibilita a manifestação de distintas variantes linguísticas não padrão. Ainda que determinados fatos apontem para uma norma brasileira fortemente enraizada no modelo europeu, não se pode deixar de declarar que o final do século XIX continuou a ser um momento de afirmação nacional e que os falantes do PB já possuíam sua própria variedade, sua própria gramática.

Em relação aos gêneros textuais, adotando-se a posição de que o domínio discursivo jornalístico, em particular o jornal, é composto por vários gêneros textuais, identificados a partir das dimensões que se referem à função e à organização, entre outras, projetou-se a ideia, quanto à colocação pronominal, de usos diversificados relacionados, frontalmente, com os gêneros em que os pronomes clíticos estavam inseridos - cabe lembrar que os textos são as materializações dos gêneros. Supôs-se, de forma geral, segundo as particularidades de cada gênero, a observação, nesses textos, ora do domínio da ênclise (a um único verbo) e da posição pré-complexo verbal (relacionada a mais de um verbo), tidas como as formas linguísticas conservadoras, ora de um uso mais acentuado da posição pré-verbal, quando o pronome estivesse unido a apenas um verbo, e intraverbal, quando investigados complexos verbais, consideradas as formas linguísticas inovadoras.

A seguir, visando ao acréscimo de mais informações aos estudos da posição dos pronomes clíticos, são apresentadas as orientações teóricas que nortearam o desenvolvimento deste estudo, os parâmetros utilizados para as análises dos dados coletados e os resultados alcançados.

\section{Fundamentos teóricos: variação e mudança linguísticas e gêneros textuais}

$\mathrm{Na}$ sequência, detalham-se as abordagens adotadas neste trabalho; isto é, discutem-se pressupostos da Teoria da Variação e 
Mudança Linguísticas e noções fundamentais acerca dos gêneros textuais, inclusive dos gêneros presentes nos jornais.

\section{Pressupostos da Sociolinguística Variacionista: a primazia da dimensão sócio-histórica na investigação da língua}

Na Sociolinguística, oferece-se ao falante não um sistema unitário e imutável, que se impõe irredutivelmente, mas um sistema sobre o qual o falante, de acordo com a prática linguística em questão, seleciona, entre as variedades existentes, a que deseja utilizar. Há a concepção da heterogeneidade, opondo-se, inclusive, à visão anterior de que a comunidade de fala é normalmente homogênea. Resgata-se, também, sob essa perspectiva, a historicidade, isto é, o processo histórico de constituição da língua.

Embora algumas pesquisas já houvessem sido realizadas, ou estavam sendo, foi com os estudos da comunidade de Martha's Vineyard (dissertação de mestrado - 1962) e da estratificação social do inglês falado em Nova Iorque (tese de doutorado, publicada em 1966), de William Labov, que se estabeleceram as bases teórico-metodológicas da pesquisa Sociolinguística Variacionista e, assim, pôde-se reabrir a questão da mudança linguística, muitas vezes descartada, segundo a corrente teórica em voga.

Deve estar claro, quanto à mudança linguística, que não há interpretações únicas. Os julgamentos dependerão da orientação teórica adotada. As concepções que apreendem a língua como resultado de um longo e ininterrupto processo histórico, motivado, entre outros, por aspectos sociais, como é o caso da Sociolinguística, tomam a mudança linguística como "um processo contínuo e o subproduto inevitável da interação linguística” (Weinreich; Labov; Herzog, 2006 [1968], p.87). Nessa perspectiva, procura-se acompanhar a história social e cultural dos falantes, correlacionando-a com a história da língua, buscando sempre realizar o encaixamento estrutural e social dos fenômenos da mudança. Segundo Weinreich, Labov e Herzog (2006 [1968], p.36), 
A chave para uma concepção racional da mudança linguística - e mais, da própria língua - é a possibilidade de descrever a diferenciação ordenada numa língua que serve a uma comunidade. [...] Um dos corolários de nossa abordagem é que numa língua que serve a uma comunidade complexa (i.e., real), a ausência de heterogeneidade estruturada é que seria disfuncional.

Em muitos estudos sociolinguísticos, e em particular neste, adota-se, portanto, a Teoria da Variação e Mudança Linguísticas, proposta por Weinreich, Labov e Herzog (2006 [1968]) e Labov (1982; 1994; 2001; 2008 [1972]).

Destaca-se que qualquer parte da língua pode mudar, desde aspectos fonéticos até aspectos de sua organização semântica e pragmática. Podem ocorrer isoladas, mas também podem estar inter-relacionadas. Mesmo que os falantes não as percebam, as mudanças sempre estão ocorrendo. Às vezes, podem se dar de forma discreta, abrupta - uma mudança simultânea de gramática por parte de um grande número de falantes, apesar da improbabilidade desse acontecimento -, mas a maioria das investigações mostra que se dão de forma lenta e gradual. Nota-se que a variação - condição essencial para que se dê a mudança - ocorre, justamente, quando duas ou mais variedades passam a se confrontar dialeticamente no universo das relações sociointeracionais. Cabe ainda mencionar que, embora seja uma das características da mudança a sua regularidade, esta se apresenta relativizada. Os processos de mudança são complexos, não sendo, em alguns casos, uniforme a sua difusão, tanto no interior da língua quanto entre os diversos grupos de falantes.

Embora inicialmente grande parte dos estudos variacionistas tenha abordado apenas os sons da língua - isso se deve às próprias características das variações no nível fonético, que são, usualmente, mais frequentes que fenômenos de natureza sintática ou morfológica e que não envolvem relações de significado lexical ou gramatical -, para que a Teoria da Variação e Mudança Linguísticas contribua ao estudo da língua em seu contexto social, assim como esclarece 
Labov (2008 [1972]), todos os tipos de variação, nos níveis fonético-fonológico, morfológico, sintático, semântico, lexical e pragmático da língua, merecem atenção e devem ser investigados.

Quando o estudo se circunscreve às premissas da Sociolinguística Variacionista, considera-se a variabilidade inerente ao fenômeno linguístico, como já mencionado. No entanto, necessita-se ir além desse reconhecimento; observações minuciosas das correlações entre as variedades linguísticas e fatores sociais, geográficos e estilísticos devem ser feitas. Como afirmam Weinreich, Labov e Herzog (2006 [1968], p.107): “Certamente não basta apontar a existência ou a importância da variabilidade: é necessário lidar com os fatos de variabilidade com precisão suficiente para nos permitir incorporá-los em nossas análises da estrutura linguística”. Buscando sintetizar a proposta da perspectiva adotada, é possível assegurar que língua e variabilidade estão essencialmente ligadas, e que a

Sociolinguística encara a diversidade linguística não como um problema, mas como uma qualidade constitutiva do fenômeno linguístico. Nesse sentido, qualquer tentativa de buscar apreender apenas o invariável, o sistema subjacente - se valer de oposições como "língua e fala", ou competência e performance - significa uma redução na compreensão do fenômeno linguístico (Alkmim, 2001, p.33).

\section{Gêneros: conceitos, conflitos e outras características}

Segundo Bakhtin (1992 [1979], p.279),

A utilização da língua efetua-se em forma de enunciados (orais e escritos), concretos e únicos, que emanam dos integrantes duma ou doutra esfera da atividade humana. O enunciado reflete as condições específicas e as finalidades de cada uma dessas esferas, não só por seu conteúdo (temático) e por seu estilo verbal, ou seja, pela seleção operada nos recursos da língua - recursos lexicais, fraseológicos e gramaticais -, mas também, e sobretudo, por sua construção 
composicional. Estes três elementos (conteúdo temático, estilo e construção composicional) fundem-se indissoluvelmente no todo do enunciado, e todos eles são marcados pela especificidade de uma esfera de comunicação. Qualquer enunciado considerado isoladamente é, claro, individual, mas cada esfera de utilização da língua elabora tipos relativamente estáveis de enunciados, sendo isso que denominamos gêneros do discurso.

Nota-se que as reflexões bakhtinianas se originam a partir da concepção, imprescindível àqueles que consideram a perspectiva sócio-histórica e dialógica da língua, da interconexão entre a utilização da linguagem e as atividades humanas. Assim, "os enunciados devem ser vistos na sua função no processo de interação" (Fiorin, 2008, p.61).

Quanto às três partes que constroem o todo que constitui o enunciado, Fiorin (ibidem, p. 62) as esclarece considerando que:

O conteúdo temático não é o assunto específico de um texto, mas é um domínio de sentido de que ocupa o gênero. [...] A construção composicional é o modo de organizar o texto, de estruturá-lo. [...] O ato estilístico é uma seleção de meios linguísticos. Estilo é, pois, uma seleção de certos meios lexicais, fraseológicos e gramaticais em função da imagem do interlocutor e de como se presume sua compreensão responsiva ativa do enunciado.

Hoje, fundamentadas na herança bakhtiniana, sobressaem-se, nos planos nacional e internacional, diversas perspectivas teóricas que, de acordo com os seus objetivos, lidam diferentemente com a questão dos gêneros.

Assentou-se, neste trabalho, que os gêneros textuais são fenômenos históricos, vinculados à vida cultural e social, concretizados através da linguagem (Marcuschi, 2005, 2006, 2008). São interativos, nunca surgem num grau zero, já que são condicionados por outros. Pode-se dizer, por representarem as mais diversas atividades comunicativas, que a classificação dos gêneros não é feita 
de modo exato e fácil, a ponto de sua identificação parecer difusa e aberta. "Os gêneros textuais são dinâmicos, de complexidade variável e não sabemos ao certo se é possível contá-los todos, pois, como são sócio-históricos e variáveis, não há como fazer uma lista fechada, o que dificulta ainda mais sua classificação" (idem, 2008, p.159). Embora seja complicado nomear cada gênero textual, as denominações não são criações individuais, mas rótulos constituídos histórica e socialmente.

Em meio às observações de Bakhtin (1992 [1979]), relidas e utilizadas pelos estudos posteriores, como já citado, também está a variedade dos gêneros, considerada vasta e justificada pelo fato dos gêneros variarem conforme as circunstâncias, a posição social e o relacionamento pessoal entre os interlocutores.

Outro ponto a ser ressaltado, em relação à produção dos gêneros textuais, para também melhor compreendê-los, é que, embora alguns sejam tidos como entidades flexíveis, em certo grau, coíbem os usuários de fazer escolhas totalmente livres. De acordo com Marcuschi (2008, p.156), "[...] os gêneros têm uma identidade e eles são entidades poderosas que, na produção textual, nos condicionam a escolhas que não podem ser totalmente livres e aleatórias, seja sob o ponto de vista do léxico, grau de formalidade ou natureza dos temas". Desse modo, apropriados a suas especificidades, por um lado, estão abertos a opções, estilo, criatividade e variação e, por outro, impõem restrições e padronizações, "[...] já que estamos imersos numa sociedade que nos molda sob vários aspectos e nos conduz a determinadas ações" (ibidem, p.162).

A possibilidade de optar por formas menos ou mais estandardizadas pode se referir ao fato de os gêneros se distribuírem pela oralidade e pela escrita num contínuo, desde os mais informais aos mais formais e em todos os contextos e situações da vida cotidiana. Assim, os gêneros ligados à esfera privada podem ser menos marcados à orientação formal e os gêneros destinados à esfera da vida pública podem estar mais condicionados por valores normativos, distanciando-se, em medidas cada vez maiores, da informalidade. Verifica-se, em certos casos, que alguns chegam a ser rígidos. 
Observa-se, diante do rico conteúdo envolvido pelo estudo dos gêneros textuais, que suas reflexões se tornaram, atualmente, indispensáveis àqueles que anseiam estudar a linguagem, ainda que pelas óticas mais diversas. Assim, por apresentar propriedade multidisciplinar, o estudo dos gêneros pode englobar uma análise do texto e do discurso e uma descrição da língua e visão da sociedade, e ainda tentar responder a questões de caráter sociocultural no uso da língua de maneira geral.

\section{Os gêneros textuais como subsídios para pesquisas sociolinguísticas - contribuição e relevância}

As investigações que se reportam a períodos mais remotos da língua podem fazer uso, para coleta e análise de dados, apenas, de documentos escritos. Todavia, embora a escrita apresente, por sua história e funções sociais, uma realidade mais estável e permanente que a língua falada, pode-se considerar que os textos escritos, assim como as produções orais, variam de acordo com suas finalidades e condições de criação, podendo abranger desde os que representam um estilo mais informal ${ }^{3}$ até os que se encaixam num estilo mais formal. ${ }^{4}$ Para identificá-los, portanto, deve-se levar em conta quem os produz, a quem são destinados e, primordialmente, em quais contextos se materializam.

Segundo Labov (2008 [1972], p.91),

Os linguistas sempre tiveram consciência dos problemas de variação estilística. A prática normal é pôr essas variantes de lado não porque sejam consideradas menos importantes, mas porque as técnicas da linguística são tidas como inadequadas e insuficientes para lidar com elas. [...] Uma vez que a influência do condicionamento estilístico sobre o comportamento linguístico é considerada meramente estatística, ela leva à afirmação de probabilidade

3 Nota-se, no estilo informal, por parte do falante/escritor, o grau mínimo de atenção dada às formas empregadas.

4 Quanto ao estilo formal, verifica-se o contrário. Há um maior monitoramento das formas linguísticas utilizadas. 
mais do que de regra e é, portanto, desinteressante para muitos linguistas.

No entanto, em sua tese de doutoramento - The social stratification of english in New York, de 1966, como já informado acima-, ao analisar as variáveis fonológicas, num total de cinco, além de relacionar o uso de suas variantes a aspectos linguísticos e a determinadas questões sociais, Labov salienta a importância de observar suas realizações nos mais diversos estilos. Para isso, lista os seguintes estilos contextuais: casual, cuidadoso, leitura, lista de palavras e pares mínimos (ver Labov, 2008 [1972]). Assim como nesse estudo de Labov, alguns estudos sociolinguísticos recentes, que trabalham com a modalidade falada, têm mostrado - embora não se utilizando, na íntegra, da lista de estilos contextuais estabelecida por Labov (1966) - que há certa tendência à correlação entre situações informais e o uso preferencial de variantes não padrão, já que esses contextos pressupõem menor atenção à produção dos enunciados; por outro lado, em contextos mais formais, em que a monitoração ao uso da língua é maior, constata-se a ocorrência mais frequente de formas padrão.

Para verificar se essas relações também estão presentes em textos escritos, fonte de extração dos dados que remetem à reconstrução da história da língua, deve-se considerar a noção de gêneros textuais. À medida que os textos materializam os gêneros, torna-se possível, após caracterizá-los formal e funcionalmente, averiguar se o uso das variantes - inovadoras e conservadoras -, de determinada variável, condiz com a tendência apontada pelos estudos que lidam com a língua falada. Sugere-se que a análise seja feita a partir de vários gêneros, para que o contraste - entre a frequência de formas estigmatizadas e a ocorrência de formas de prestígio, de acordo com as especificidades de cada gênero textual - seja mais bem visualizado.

Ademais, tem-se que as mudanças que se efetuam nos gêneros textuais são indissociáveis das mudanças da vida social, que, por sua vez, entre outros aspectos, condicionam as mudanças na língua. 
Logo, consideram-se complexas e pertinentes as relações entre variação e mudança linguísticas e gêneros textuais.

\section{Os gêneros do jornal}

O estudo dos gêneros jornalísticos, há um bom tempo, além de propiciar informações relevantes para os profissionais da área do jornalismo e fornecer recursos para aqueles que buscam aprofundar seus conhecimentos a respeito do tema, tem despertado grande interesse nos estudiosos que se dedicam aos fatos da língua, por serem reconhecidos como uma rica fonte de extração e análise de dados. Entretanto, apesar dessa longa história, pouco se sabe, de forma sistemática, sobre os gêneros do jornal. Há, no jornal, um contínuo expositivo, o que dificulta estabelecer as delimitações entre os gêneros que o formam. De acordo com Bonini (2006, p.65),

A vagueza nas fronteiras intergêneros pode ser observada de dois pontos de vista: o estrutural e o semântico-pragmático. $\mathrm{O}$ estrutural, neste caso, diz respeito ao modo como o jornal se organiza e o semântico-pragmático corresponde ao modo como os textos são enunciados.

Deve-se mencionar, ainda, que nos jornais do século XIX e início do século XX nem sempre são aplicáveis os tipos de gêneros descritos para os jornais atuais. Observa-se, portanto, que as discussões sobre esses aspectos ainda são preliminares. No entanto, ressalta-se que, embora sofram alterações com o tempo, as especificações dos gêneros não são dispensáveis; ao contrário, são importantes para que sejam compreendidos quais os gêneros vigentes e quais as perspectivas jornalísticas de determinada época.

Em um jornal, percebe-se também, como dito anteriormente, de acordo com os recursos linguísticos utilizados e a função comunicativa almejada, que nos textos, representantes dos gêneros, podem se concentrar variantes linguísticas padrão e não padrão.

Para Bonini (2004), o jornal deve ser considerado um gênero que abriga outros, isto é, um hipergênero, porque preenche quesi- 
tos como propósitos comunicativos próprios, organização textual característica, embora ainda não conhecida em seus detalhes, e produtores e receptores definidos. Para ele (idem, 2003, p.72), "sendo o gênero um material sígnico relativamente compartilhado entre os membros de determinada comunidade, e que, tendo o jornal a mesma propriedade sígnica do gênero, ele seria também um tipo de gênero [...].”.

\section{Análise dos dados: o corpus e as variáveis (dependentes e independentes)}

Em seguida, discorre-se a respeito da constituição do corpus escolhido como matriz das análises, do envelope de variação considerado - por se tratar de um estudo circunscrito às premissas da Sociolinguística Variacionista - e dos elementos condicionadores, extralinguísticos e linguísticos, indicados como possíveis motivadores para a utilização de determinada variante.

\section{A constituição do corpus: jornais paulistanos em foco}

O corpus de análise desta investigação foi constituído por textos escritos que compunham determinado periódico da cidade de São Paulo, no período de 1880 a 1920 . Foi observado o jornal $A$ Província de São Paulo, que, a partir de 1890, renomeado, passa a ser O Estado de São Paulo.

Reforça-se aqui, novamente, a opinião defendida no presente estudo de que nos periódicos, por serem formados por vários gêneros textuais, que podem ocorrer como formas rígidas ou inovadoras ou mistas, há a convivência de formas linguísticas padrão e não padrão. Desse modo, os textos presentes nos jornais são materiais relevantes para estudos de variação e mudança linguísticas.

Coletaram-se, a priori, todas as sentenças que apresentavam o clítico pronominal, observando-se todos os gêneros que compunham o jornal. 
Excluíram-se das análises as ocorrências obtidas em folhetins, em poesias - encontradas em número restrito - e em textos republicados de outros jornais. Interessava a esta investigação a escrita procedente daqueles que representavam o jornal averiguado e, também, de seus leitores. ${ }^{5}$

Pelo cunho teórico, pelos objetivos e pelo fenômeno linguístico abordado neste estudo, desenvolveu-se a análise de um exemplar, em sua totalidade, de cinco em cinco anos. Os exemplares foram examinados minuciosamente, registrando-se, de acordo com o avanço dos anos, modificações em suas estruturas e funções comunicativas, refletindo-se, de forma justificável, também, na aparição de outros gêneros textuais, não identificados nos primeiros exemplares estudados.

Para a constituição deste corpus, cabe citar, enfrentaram-se situações distantes da ideal, como exemplares microfilmados em péssimo estado de leitura. Contudo, através da "arte de fazer o melhor uso de maus dados”, (Labov, 1994, p.11) foi possível vislumbrar a riqueza, sob muitos aspectos, do material coletado.

\section{As variáveis dependentes: próclise $\mathrm{x}$ ênclise / cl V1 V2 $x$ V1 cl V2 x V1 V2 cl}

A variação linguística constitui fenômeno universal. Às formas em variação, dá-se o nome de variantes. As variantes linguísticas são, portanto, as diversas formas alternativas de se dizer a mesma coisa, em um mesmo contexto, e com o mesmo valor de verdade. ${ }^{7}$

5 Ainda foram encontrados, porém excluídos das análises, 59 dados de mesóclise e 34 construções que apresentavam mais de um pronome clítico adjungido ao verbo, ou ao complexo verbal, ou, no caso das lexias verbais simples, continham um elemento interveniente entre o clítico pronominal e o verbo hospedeiro.

6 "[...] art of making the best use of bad data", tradução nossa.

7 Deve-se frisar, no entanto, que as variantes são idênticas em valor de verdade ou referencial, mas se opõem em sua significação social e/ou estilística (Labov, 1982; 2001; 2008 [1972]). 
Em conjunto, configuram um fenômeno variável, nomeado, tecnicamente, como variável dependente. Assim, como variáveis dependentes, foram consideradas as seguintes estratégias de realização do clítico pronominal na oração:

- Quando adjungido a uma lexia verbal simples Clítico em posição pré-verbal (próclise):

(01) Assim promette na medida progressiva de suas forças auxiliar ao commercio, á lavoura, ás artes, industrias, sciencias; e literatura, tratando os assumptos que lhes digam respeito, e abrindo espaço a todos os talentos e aptidões que em suas paginas queiram apparecer. (A Província de São Paulo, São Paulo, 1880 - gênero Editorial)

Clítico em posição pós-verbal (ênclise):

(02) Recommenda-se tambem a Cerevisina para o tratamento do acne [...]. (O Estado de São Paulo, São Paulo, 1905 - gênero Anúncio)

- Quando adjungido a um complexo verbal Clítico em posição pré-complexo verbal (cl V1 V2):

(03) $[\ldots]$ a $<<$ Provincia de São Paulo $>>$ ha conseguido cobrir a sua despeza com a receita, o que lhe tem proporcionado uma carreira livre e desassombrada dos perigos que cercam as emprezas jornalisticas entre nós. (A Província de São Paulo, São Paulo, 1880 - gênero Editorial)

Clítico em posição intracomplexo verbal (V1 cl V2):

(04) $\mathrm{Na}$ <garden-party> fez-se ouvir o bello grupo de amadores musicaes [...]. (O Estado de São Paulo, São Paulo, 1910 - gênero Notícia) 
Clítico em posição pós-complexo verbal (V1 V2 cl):

(05) Se quizerem vender-lhes qualquer limonada purgativa em logar do Pó Rogé, desconfiem [...]. (O Estado de São Paulo, São Paulo, 1905 - gênero Anúncio)

Definiram-se como complexos verbais quaisquer tipos de construções que apresentassem dois verbos e em que o último deles era uma forma não finita. Cabe destacar, ainda, que não foram consideradas características prosódicas para a verificação das posições dos clíticos pronominais.

\section{As variáveis independentes}

A cada variante correspondem certos contextos que a favorecem - variáveis independentes. Assim, as variáveis independentes ou grupos de fatores podem ser de natureza externa ou interna à língua.

\section{As variáveis independentes extralinguísticas}

Nesta pesquisa, no conjunto de variáveis externas à língua, reuniram-se fatores sociais (ano do exemplar) e contextuais (grau de formalidade, através da reflexão acerca dos gêneros textuais). Aqueles se referiam a aspectos sócio-históricos; estes, a características circunstanciais que envolviam o evento de fala.

Quanto aos gêneros textuais, foram averiguados os seguintes: edital, notícia, aviso, anúncio, classificado, editorial, artigo, resenha ou crítica, crônica, carta do leitor, nota e comentário.

\section{As variáveis independentes linguísticas}

Os condicionamentos linguísticos, aqui, apresentam-se, em relação ao corpus, divididos em dois grupos: (i) clíticos adjungidos a um único verbo e (ii) clíticos adjungidos a um complexo verbal.

- Grupos de fatores observados quando o clítico pronominal estava adjunto a uma lexia verbal simples 
Observaram-se: 1) tipo de clítico; 2) função do clítico; 3) formas verbais; 4) tipo de verbo, do ponto de vista lógico-semântico; 5) presença ou ausência de elemento proclisador na oração; e, 6) verbo hospedeiro do pronome clítico em início, ou não início, absoluto na oração.

- Grupos de fatores observados quando o clítico pronominal estava adjunto a um complexo verbal

Além de alguns dos grupos de fatores citados acima - tipo de clítico, função sintática do clítico, presença (ou ausência) de possível proclisador na oração e, agora, complexo verbal hospedeiro do pronome clítico em início (ou não início) absoluto na oração -, foram controlados outros quanto à posição do clítico pronominal em relação a mais de um verbo, tais como: i) forma verbal do primeiro verbo; ii) forma verbal do segundo verbo; iii) presença ou ausência de elemento interveniente entre os verbos do complexo verbal; e, iv) tipo do complexo verbal.

\section{Descrição dos principais resultados}

Os resultados apresentados foram quantificados pelo programa Goldvarb X (Sankoff, Tagliamonte, Smith, 2005). Deve-se mencionar que, embora tenham sido consideradas nas análises todas as variáveis independentes extralinguísticas e linguísticas mencionadas acima, privilegia-se, neste texto, quanto aos contextos em que o clítico estava adjungido a um único verbo, a descrição dos dados relacionados às variáveis independentes apontadas, pelo tratamento estatístico realizado pelo programa, como as que atuaram de forma mais relevante sobre a posição dos pronomes clíticos.

No que concerne às ocorrências de complexos verbais, discutem-se somente os dados provenientes das variáveis gênero textual; forma verbal de V2; presença ou ausência de elemento proclisador na oração e tipo de complexo verbal. Por serem análises restritas a cálculos de frequência - uma vez que a análise de multivariância só é 
possível quando houver arquivado um conjunto de resultados com um valor de aplicação binário -, seguidas dos devidos cruzamentos das variáveis entre si, a variável gênero textual se mostrou a mais significativa e, quanto às variáveis independentes linguísticas mencionadas, revelaram-se as mais interferentes no posicionamento do pronome clítico. ${ }^{8}$

Na tabela a seguir são mostrados os números de ocorrências dos clíticos pronominais, de acordo com os contextos - lexias verbais simples e complexos verbais - em que foram averiguados, num total de 3.248 dados.

Tabela 1 - Distribuição geral das ocorrências de clíticos pronominais

\begin{tabular}{l|c}
\hline & Jornais/São Paulo \\
\hline Lexias verbais simples & 2.785 \\
\hline Complexos verbais & 463 \\
\hline Total & 3.248 \\
\hline
\end{tabular}

\section{Próclise $\mathrm{x}$ ênclise}

Como apresentado na tabela acima, do total de 3.248 clíticos pronominais encontrados, 2.785 estavam adjuntos a um único verbo, dividindo-se em 983 (35,3\%) pronomes que ocupavam a posição pré-verbal e $1.802(64,7 \%)$ clíticos em posição pós-verbal.

\section{Variável gênero textual}

Foram elencados os seguintes gêneros textuais, como descrito anteriormente: edital, editorial, notícia, nota, comentário, aviso, artigo, resenha (ou crítica), crônica, carta do leitor, anúncio e classificado. Segundo os traços peculiares desses gêneros textuais, esperava-se observar realidades diversas, em cada um deles, isto é, ora a

8 Para outras informações relacionadas aos grupos de fatores aqui não detalhados, ver Biazolli (2010). 
predominância do pronome enclítico ora a do pronome proclítico, de acordo com o gênero textual averiguado.

Acreditava-se que os gêneros edital, notícia e aviso, embora em escalas diferentes - já que o edital, por exemplo, em consequência da sua função essencial de documento oficial, caracteriza-se pelo seu caráter demasiadamente rígido -, assegurassem, como resultado de suas estruturas organizacionais e de seus conteúdos detalhados, um uso mais representativo da forma (em geral considerada) conservadora, a ênclise.

Quanto aos gêneros anúncio e classificado, esperava-se que, embora possibilitem aos indivíduos maior liberdade de criação, devido à diversidade de temas que abrangem, aparecessem redigidos, quase invariavelmente, sob as mesmas formas, privilegiando, também, a colocação enclítica.

Por outro lado, esperava-se nos gêneros textuais editorial, artigo, resenha (ou crítica), crônica e carta do leitor a incorporação de usos linguísticos variados, destacando-se a posição pré-verbal. Tal apontamento, no caso do gênero editorial, deu-se por sua característica de apresentar ao leitor determinado acontecimento e persuadi-lo a adotar a sua opinião, utilizando-se de formas mais usuais, e, quanto aos demais gêneros - artigo, resenha (ou crítica), crônica e carta do leitor -, por poderem retratar os assuntos mais diversos e por apresentarem finalidades as mais distintas, salientando-se, muitas vezes, características associadas ao próprio escritor.

Por fim, no que concerne aos gêneros nota e comentário, considerando-se o dinamismo e a brevidade de seus textos e apostando na transmissão clara e direta de determinada mensagem, presumiu-se maior aceitação da próclise; no entanto, acentuou-se, também, a possibilidade da verificação da ênclise, destacando-se a intenção de quem os produz e, consequentemente, o uso de formas mais rebuscadas.

Os resultados obtidos, em relação à posição dos pronomes clíticos, de acordo com os gêneros textuais, podem ser apurados na tabela seguinte. 
Tabela $2^{9}$ - Número de ocorrências, percentuais e pesos relativos dos pronomes clíticos, de acordo com os gêneros textuais

\begin{tabular}{l|c|c|c|c|c|c|c|c}
\hline \multirow{2}{*}{} & \multicolumn{3}{|c|}{ Próclise } & \multicolumn{3}{c|}{ Enclise } & \multicolumn{2}{c}{ Total } \\
\cline { 2 - 10 } & $\mathbf{N}$ & $\%$ & PR & N & $\%$ & PR & N & $\%$ \\
\hline Resenha & 29 & 72.5 & 0.859 & 11 & 27.5 & 0.141 & 40 & 1.5 \\
\hline Editorial & 65 & 65 & 0.832 & 35 & 35 & 0.168 & 100 & 3.7 \\
\hline Artigo & 57 & 60.6 & 0.830 & 37 & 39.4 & 0.170 & 94 & 3.5 \\
\hline Carta do leitor & 144 & 57.1 & 0.783 & 108 & 42.9 & 0.217 & 252 & 9.3 \\
\hline Comentário & 20 & 51.3 & 0.722 & 19 & 48.7 & 0.278 & 39 & 1.4 \\
\hline Aviso & 104 & 49.1 & 0.702 & 108 & 50.9 & 0.298 & 212 & 7.9 \\
\hline Edital & 78 & 42.9 & 0.639 & 104 & 57.1 & 0.361 & 182 & 6.7 \\
\hline Notícia & 249 & 41 & 0.620 & 358 & 59 & 0.380 & 607 & 22.5 \\
\hline Nota & 97 & 28.4 & 0.493 & 245 & 71.6 & 0.507 & 342 & 12.7 \\
\hline Anúncio & 73 & 18.9 & 0.356 & 314 & 81.1 & 0.644 & 387 & 14.3 \\
\hline Classificado & 12 & 2.7 & 0.062 & 435 & 97.3 & 0.938 & 447 & 16.5 \\
\hline Total & 928 & 34.3 & & 1774 & 65.7 & & 2702 \\
\hline
\end{tabular}

Identificou-se significativa relação entre as considerações, descritas acima, e os resultados averiguados.

Quanto aos dados dos gêneros edital, notícia e aviso - ainda que o último tenha apresentado uma diferença bastante comedida entre as ocorrências de próclise e ênclise (cf. Tabela 2) -, pôde-se dizer que confirmaram a tendência de que a ênclise prevalece em textos com estrutura e papel a desempenhar mais cuidadosos, sendo produzidos, então, com maior monitoramento. No entanto, os pesos relativos apontaram para a próclise.

Os resultados provenientes dos gêneros editorial, artigo, resenha e carta do leitor permitiram afirmar a predominância da próclise em textos que, muitas vezes, principalmente de acordo com os temas que retratam, procuram construir um lugar de familiaridade para a relação enunciador/enunciatário, qualificando-se como mais subjetivos.

9 O gênero crônica foi encontrado no periódico de 1920. Por estar presente apenas em um exemplar, foi desconsiderado da análise. 
O fato dos gêneros anúncio e classificado terem apresentado predomínio relevante do uso do pronome enclítico - no caso do classificado, a posição pós-verbal foi praticamente categórica, apresentando tendência ao uso da próclise de apenas 0.062 - corroborou a ideia de possuírem certo grau de rigidez, através do uso de expressões cristalizadas.

O comportamento dos gêneros nota e comentário revelou orientações diversas. No gênero nota, as frequências indicaram expressiva diferença entre os usos dos pronomes proclíticos e enclíticos e, no gênero comentário, assinalaram representativo equilíbrio entre eles. Quanto aos pesos relativos, naquele gênero se notou uma tendência discreta à ênclise $(0.507)$ e, neste, notável significância da próclise (0.722). Desses resultados, portanto, pôde-se dizer que esses fatores não se mostraram relevantes, por si sós, para explicar a variação. ${ }^{10}$

\section{Variáveis presença ou ausência de elemento proclisador, formas verbais e verbo hospedeiro em início, ou não início, absoluto na oração}

Quanto ao controle das variáveis independentes linguísticas, fez-se um recorte na amostra de dados analisados, compondo-se, assim, uma subamostra com 495 dados.

As primeiras rodadas apresentaram knockouts, excluídos posteriormente. Assim, no total, para as análises em função das variáveis independentes linguísticas, foram computados 441 usos de pronomes clíticos.

A variável presença/ausência de atrator se mostrou, como previsto, um relevante controlador da ordem dos clíticos pronominais, selecionada como o grupo de fatores mais significativo para a motivação da colocação pronominal. O comportamento dos clíticos variou, consideravelmente, segundo a existência, na oração, de um elemento proclisador. Quando não presente, o uso do pronome

10 Para outras informações, referentes aos resultados da variável gênero textual relacionados a contextos linguísticos, ver Biazolli (2010). 
enclítico, no maior número dos casos, foi a opção escolhida, revelando, assim, maior obediência à norma-padrão vigente naquela época.

A tabela a seguir apresenta os resultados mais bem detalhados.

Tabela 3 - Número de ocorrências, percentuais e pesos relativos dos pronomes clíticos, de acordo com a presença ou ausência de elemento proclisador na oração

\begin{tabular}{l|c|c|c|c|c|c|c|c}
\hline & \multicolumn{3}{|c|}{ Próclise } & \multicolumn{3}{c|}{ Enclise } & \multicolumn{2}{c}{ Total } \\
\cline { 2 - 9 } & N & $\%$ & PR & N & $\%$ & PR & N & $\%$ \\
\hline Presença & 124 & 67.8 & 0.816 & 59 & 32.2 & 0.184 & 183 & 41.5 \\
\hline Ausência & 13 & 5 & 0.258 & 245 & 95 & 0.742 & 258 & 58.5 \\
\hline Total & 137 & 31.1 & & 304 & 68.9 & & \multicolumn{2}{c}{441} \\
\hline
\end{tabular}

Ressaltou-se, entretanto, o fato de terem aparecido casos em que se optou pelo uso do pronome enclítico, mesmo com a presença do elemento proclisador - como visto nos exemplos de 06 a 07 , em que o elemento atrator do pronome clítico aparece sublinhado.

(06) [...] conta a Provincia de São Paulo fazer da sua independencia o apanagio de sua força e a medida da severa moderação, sisudez, franqueza, lealdade e criterio em que fundará o salutar prestigio a que destina-se a imprensa livre e consciente. (A Província de São Paulo, São Paulo, 1880)

(07) No caso de não terminar-se o leilão, continuará no dia immediato ás 10 1/2 pa manhã. (A Província de São Paulo, São Paulo, 1885)

Deve-se lembrar que, na história do português, sempre houve a obrigatoriedade, prescrita nos compêndios gramaticais, de se utilizar a próclise em contextos com uma série de elementos - partículas negativas, pronomes indefinidos, interrogativos e relativos, conjunções subordinativas e coordenativas, advérbios, preposições e orações optativas - que ficaram assim nomeados operadores de próclise. 
Uma primeira impressão, quanto aos casos de ênclise mesmo na presença de proclisadores, é a de que seriam fruto de hipercorreção, ou seja, uma tentativa de chegar à gramática alvo, cujo funcionamento estilístico, no período, apontaria para a ênclise.

Uma vez que a ênclise era tida, e por uma maioria ainda hoje é conservada, como a posição normal dos pronomes átonos, inclusive quando o sujeito viesse imediatamente antes do verbo, em orações afirmativas, evidenciou-se, também, uso proclítico em contextos em que não havia a presença do elemento proclisador (cf. exemplos 08 e 09).

(08) A alternativa, no entanto, se dissipa logo no contexto irrefragavel do livro [...]. (O Estado de São Paulo, São Paulo, 1910)

(09) O sabonete Rifger, conhecido ha mais de 10 annos, se impõe como o melhor para o banho [...]. (O Estado de São Paulo, São Paulo, 1915)

Desse modo, puderam-se apontar inovações referentes à norma padrão vigente naquela época e que vigora até os dias atuais.

Sobre a variável formas verbais, destacou-se o seu aparecimento como a segunda mais relevante para a motivação da colocação pronominal.

Os resultados são apresentados a seguir.

Tabela 4 - Número de ocorrências, percentuais e pesos relativos dos pronomes clíticos, de acordo com as formas verbais

\begin{tabular}{l|c|c|c|c|c|c|c|c}
\hline \multirow{2}{*}{$\begin{array}{l}\text { Formas } \\
\text { Verbais }\end{array}$} & \multicolumn{3}{c|}{ Próclise } & \multicolumn{3}{c|}{ Enclise } & \multicolumn{2}{c}{ Total } \\
\cline { 2 - 9 } & $\mathrm{N}$ & $\%$ & $\mathbf{P R}$ & $\mathrm{N}$ & $\%$ & PR & N & $\%$ \\
\hline $\begin{array}{l}\text { Pretérito Imperfeito } \\
\text { do Indicativo }\end{array}$ & 14 & 87.5 & 0.999 & 2 & 12.5 & 0.001 & 16 & 3.6 \\
\hline $\begin{array}{l}\text { Pretérito Perfeito do } \\
\text { Indicativo }\end{array}$ & 31 & 47.7 & 0.589 & 34 & 52.3 & 0.411 & 65 & 14.7 \\
\hline Presente do Indicativo & 76 & 28.3 & 0.530 & 193 & 71.7 & 0.470 & 269 & 61 \\
\hline Gerúndio & 3 & 7 & 0.204 & 40 & 93 & 0.796 & 43 & 9.8 \\
\hline Infinitivo & 13 & 27.1 & 0.109 & 35 & 72.9 & 0.891 & 48 & 10.9 \\
\hline Total & 137 & 31.1 & & 304 & 68.9 & & & 441 \\
\hline
\end{tabular}


Os dados pertencentes aos jornais paulistanos considerados na referida rodada foram constituídos apenas de verbos do modo indicativo, tempos presente, pretérito perfeito e pretérito imperfeito e formas nominais - infinitivo e gerúndio. Os resultados, quanto aos verbos do modo indicativo, revelaram usos equilibrados de ambas as posições - proclítica e enclítica -, exceto para o tempo pretérito imperfeito, marcado por um índice elevadíssimo de significância, 0.999, para a ocorrência da próclise. Quanto às formas nominais, mostraram-se motivadoras, principalmente o infinitivo, para o uso do pronome em posição pós-verbal.

Convém ressaltar, ainda, que, na primeira rodada, dados referentes aos tempos presente, pretérito e futuro do subjuntivo, futuro do presente do indicativo e imperativo afirmativo foram registrados. Os clíticos adjungidos a verbos nos tempos do modo subjuntivo ocorreram em posição pré-verbal, de forma absoluta, como o esperado, uma vez que apresentam natureza subordinativa, ocorrendo, também, em orações que exigem conjunções e palavras QU, típicos atratores. Foram coletados quinze dados referentes ao presente do subjuntivo, seis ao pretérito do subjuntivo e quatro concernentes ao futuro do subjuntivo.

Quanto ao futuro do presente do indicativo, observou-se, a partir de oito dados, o uso quase categórico da próclise, podendo-se - ainda que em sete dos dados coletados houvesse a presença de algum elemento proclisador - interpretá-lo como uma solução para a tendência de se evitar a mesóclise. $\mathrm{O}$ fato de se escolher a próclise, e não a ênclise, ainda revelou e confirmou a opção do português brasileiro pelo pronome proclítico.

A posição enclítica, por outro lado, foi claramente definida como a posição preferida quando o clítico estava adjunto a um verbo no imperativo afirmativo, notando-se essa realização nos catorze dados encontrados. Observou-se que o contexto de verbo hospedeiro do pronome clítico em início absoluto na oração ocorreu em todos esses dados.

E, por fim, outra importante variável, decisiva para o comportamento dos clíticos pronominais, visto que foi selecionada como a terceira mais relevante, foi a posição, inicial ou não, do verbo ao qual o pronome estava adjungido na oração. 
Em início absoluto, verificou-se a realização quase categórica do pronome enclítico, assim como é prescrito nos estudos normativos; e, em não início absoluto, observou-se a possível alternância entre próclise e ênclise, $56.4 \%$ e 43.6\%, respectivamente, conforme indicado na tabela a seguir. Quanto ao peso relativo, em relação a não início absoluto, mostrou-se a significativa tendência ao uso da próclise.

Tabela 5 - Número de ocorrências, percentuais e pesos relativos dos pronomes clíticos, de acordo com o verbo hospedeiro do pronome clítico em início, ou não início, absoluto na oração

\begin{tabular}{l|c|c|c|c|c|c|c|c}
\hline & \multicolumn{3}{|c|}{ Próclise } & \multicolumn{3}{c|}{ Enclise } & \multicolumn{2}{c}{ Total } \\
\cline { 2 - 9 } & $\mathbf{N}$ & $\%$ & $\mathbf{P R}$ & $\mathbf{N}$ & $\%$ & $\mathbf{P R}$ & $\mathbf{N}$ & $\%$ \\
\hline Não início & 136 & 56.4 & 0.952 & 105 & 43.6 & 0.048 & 241 & 54.6 \\
\hline Início & 1 & 0.5 & 0.027 & 199 & 99.5 & 0.973 & 200 & 45.4 \\
\hline Total & 137 & 31.1 & & 304 & 68.9 & & \multicolumn{2}{c}{441} \\
\hline
\end{tabular}

Quanto a esta variável, ainda se destacou o aparecimento, embora em número muito restrito, apenas um dado, do pronome proclítico em início absoluto na oração, como exemplificado abaixo.

(10) Quer louvando, quer censurando, se esforçará sempre a Provincia de S. Paulo por ser justa: é este um dever que ella se impõs em virtude de suas condições de folha diaria [...]. (A Província de São Paulo, São Paulo, 1880)

Tal comportamento, transgredindo os preceitos impostos pelas instituições normativas, apontou, como já sabido, um caráter relevante, e inovador, da realidade linguística do português brasileiro: o uso da próclise em primeira posição na oração, produto de uma norma linguística brasileira.

\section{cl V1 V2 x V1 cl V2 x V1 V2 cl}

Encontrou-se um total de 463 dados, distribuídos da seguinte maneira: 199 vezes (43\%) o clítico estava em posição pré-complexo verbal - cl V1 V2 -, 118 (25, 5\%) vezes em posição intra complexo 
verbal - V1 cl V2 - e 146 (31, 5\%) vezes enclítico ao V2, isto é, em posição pós-complexo verbal - V1 V2 cl.

\section{Variável gênero textual}

As ponderações feitas para a análise da colocação pronominal de acordo com os gêneros textuais referentes aos pronomes clíticos adjungidos a lexias verbais simples se repetiram quando observados os pronomes em contextos de complexos verbais. Apostaram-se, de modo geral, no uso mais acentuado da posição cl V1 V2 nos gêneros edital, notícia, aviso, anúncio e classificado, na predominância, nos gêneros editorial, artigo, crônica e carta do leitor, das posições $\mathrm{V} 1 \mathrm{cl}$ V2 e V1 V2 cl e, nos gêneros nota e comentário, a alternância equilibrada das três variantes, de acordo com os pressupostos, acerca dos gêneros textuais, e em particular dos gêneros textuais jornalísticos, discorridos durante este texto.

Os resultados se encontram na tabela seguinte.

Tabela $6^{11,12}$ - Número de ocorrências e percentuais dos pronomes clíticos em complexos verbais, de acordo com os gêneros textuais

\begin{tabular}{l|c|c|c|c|c|c|c|c}
\hline & \multicolumn{2}{|c|}{ Pré-CV } & \multicolumn{2}{c|}{ Intra-CV } & \multicolumn{2}{c}{ Pós-CV } & \multicolumn{2}{c}{ Total (N-\%) } \\
\hline Edital & N-28 & $\%-63.6$ & N-12 & $\%-27.3$ & N-4 & $\%-9.1$ & 44 & 10 \\
\hline Notícia & N-50 & $\%-45.5$ & N-28 & $\%-25.5$ & N-32 & $\%-29.1$ & 110 & 25.2 \\
\hline Aviso & N-11 & $\%-22.4$ & N-15 & $\%-30.6$ & N-23 & $\%-46.9$ & 49 & 11.2 \\
\hline Anúncio & N-16 & $\%-33.3$ & N-16 & $\%-33.3$ & N-16 & $\%-33.3$ & 48 & 11 \\
\hline Classificado & N-5 & $\%-18.5$ & N-12 & $\%-44.4$ & N-10 & $\%-37$ & 27 & 6.2 \\
\hline Editorial & N-17 & $\%-73.9$ & N-3 & $\%-13$ & N-3 & $\%-13$ & 23 & 5.2 \\
\hline Artigo & N-12 & $\%-60$ & N-1 & $\%-5$ & N-7 & $\%-35$ & 20 & 4.6 \\
\hline Carta do Leitor & N-26 & $\%-44.8$ & N-13 & $\%-22.4$ & N-19 & $\%-32.8$ & 58 & 13.3 \\
\hline Nota & N-14 & $\%-29.2$ & N-11 & $\%-22.9$ & N-23 & $\%-47.9$ & 48 & 11 \\
\hline Comentário & N-4 & $\%-40$ & N-3 & $\%-30$ & N-3 & $\%-30$ & 10 & 2.3 \\
\hline Total & N-183 & $\%-41.9$ & N-114 & $\%-26.1$ & N-140 & $\%-32$ & \multicolumn{1}{c}{ N-437 } \\
\hline
\end{tabular}

11 Ainda foram encontrados, no ano de 1915, o gênero Entrevista e, no ano de 1920, o gênero Crônica. Por estarem presentes apenas em um exemplar, foram desconsiderados da análise.

12 A célula que apresentou menos de dez dados, referente ao gênero Resenha ou Crítica, com somente quatro dados, foi desprezada. 
Houve pouca, ou quase nenhuma, correlação entre as ideias propostas e os resultados averiguados quanto à colocação dos pronomes clíticos, de acordo com os gêneros textuais, em complexos verbais.

Notaram-se, apenas nos gêneros edital e notícia, os comportamentos esperados, isto é, o uso mais acentuado dos pronomes clíticos em posição cl V1 V2. Ainda, quanto ao edital, notou-se, nele, o menor índice de uso do pronome posposto ao verbo principal, apenas $9,1 \%$.

Os textos do gênero aviso apresentaram, em maior número de ocorrências, os clíticos pronominais nas posições V1 V2 cl e V1 cl V2, na devida ordem. Quanto aos gêneros anúncio e classificados, pôde-se dizer que, naquele, houve números de ocorrências idênticos paras as três posições dos pronomes clíticos - 16 dados que representaram 33.3\% -; neste, a posição V1 cl V2 foi considerada a mais produtiva. Ressaltou-se o fato de esses dois gêneros apresentarem as maiores frequências quanto à variante intracomplexo verbal.

Nos gêneros textuais em que se esperava averiguar, devido às suas características, usos mais acentuados das posições, possivelmente, tidas como as construções menos normativas, a saber: editorial, artigo e carta do leitor, revelou-se, ao contrário, como predominante o uso do pronome em posição cl V1 V2, com frequências de $73.9 \%$, 60\% e 44.8\%, respectivamente. No entanto, quanto ao gênero carta do leitor, os índices das três posições se aproximaram das frequências de uso geral dos clíticos pronominais nas posições clV1 V2, V1 cl V2 eV1 V2 cl.

Quanto aos gêneros nota e comentário, os clíticos pronominais apareceram em maior número, no primeiro, em posição $\mathrm{V} 1 \mathrm{~V} 2 \mathrm{cl}$ e, no segundo, em posição cl V1 V2. Ainda assim, verificaram-se frequências da posição V1 cl V2 próximas, de certo modo, do índice geral observado por essa posição.

\section{Variáveis forma verbal de V2, presença ou ausência de elemento proclisador na oração e tipo de complexo verbal}

De acordo com a forma verbal de V2, observaram-se os seguintes comportamentos dos clíticos pronominais: 
Tabela 7 - Número de ocorrências e percentuais da colocação dos pronomes clíticos em complexos verbais, de acordo com a forma verbal de V2

\begin{tabular}{l|c|c|c|c|c|c|c|c}
\hline $\begin{array}{c}\text { Forma } \\
\text { Verbal de V2 }\end{array}$ & \multicolumn{2}{|c|}{ Pré-CV } & \multicolumn{2}{c|}{ Intra-CV } & \multicolumn{2}{c}{ Pós-CV } & \multicolumn{2}{c}{$\begin{array}{c}\text { Total } \\
\text { (N-\%) }\end{array}$} \\
\hline Infinitivo & N-114 & $\%-33.2$ & N-83 & $\%-24.2$ & N-146 & $\%-42.6$ & 343 & 74.1 \\
\hline Gerúndio & N-6 & $\%-54.5$ & N-5 & $\%-45.5$ & N-0 & $\%-0$ & 11 & 2.4 \\
\hline Particípio & N-79 & $\%-72.5$ & N-30 & $\%-27.5$ & N-0 & $\%-0$ & 109 & 23.5 \\
\hline Total & N-199 & $\%-43$ & N-118 & $\%-25.5$ & N-146 & $\%-31.5$ & N-463 \\
\hline
\end{tabular}

Pôde-se mencionar, em relação à posição do clítico quando adjungido a um complexo verbal com o V2 na forma de particípio, a inexistência de dados que apontassem esse pronome em posição V1 V2 cl, confirmando-se a produtividade de algumas prescrições gramaticais que, para esse caso, ditam a obrigatoriedade de não deslocar o clítico pronominal para depois de um verbo principal quando este estiver no particípio.

Quanto à forma infinitivo, novamente, os resultados, de um modo geral, pareceram mostrar consentimento aos preceitos expressos pelos compêndios gramaticais, a saber: (i) quando o verbo principal estiver no infinitivo, sempre usar a ênclise ao infinitivo e (ii) quando ocorrem as condições exigidas para a anteposição do pronome a um só verbo, deve-se recorrer à próclise ao verbo auxiliar.

Assim, evidenciaram-se as preferências, com V2 na forma de infinitivo, pelas posições V1 V2 cl, cl V1 V2 eV1 cl V2, nessa ordem. Observou-se que, mesmo com a presença, em muitos casos, de um elemento proclisador na oração, ainda foi nítida a produtividade da posição V1 V2 cl - assim como mostra o exemplo 11 abaixo. No entanto, ainda se constataram, dentre os 114 dados em posição clV1 V2, as presenças de elementos proclisadores em 109 orações.

(11) O abaixo assignado vem declarar ao publico e aos seus amigos, que deixou de ser empregado da casa acima, por não poder entender-se, com o proprietario [...]. (A Província de São Paulo, São Paulo, 1880 - gênero Aviso)

Sobre a forma gerúndio, notou-se um número bastante restrito de registros, ainda mais se observados os números de casos das 
formas infinitivo (343) e particípio (109). Os dados, nos casos com V2 gerúndio, apareceram distribuídos de forma equilibrada entre as posições cl V1 V2 (54.5\%) e V1 cl V2 (45.5\%). Nenhum dado com o clítico em posição V1 V2 cl, nesse contexto, foi encontrado.

Mostrou-se relevante, motivando para determinada posição do clítico pronominal na oração, a presença ou ausência de elemento proclisador. Quando presentes, os elementos proclisadores condicionaram a colocação da variante cl V1 V2 e, quando ausentes, observou-se o aumento da produtividade das outras duas variantes -V1 clV2 eV1 V2 cl.

Os resultados gerais podem ser verificados na tabela seguinte.

Tabela 8 - Número de ocorrências e percentuais da colocação dos pronomes clíticos em complexos verbais, de acordo com a presença ou ausência de elemento proclisador na oração

\begin{tabular}{l|c|c|c|c|c|c|c|c}
\hline & \multicolumn{2}{|c|}{ Pré-CV } & \multicolumn{2}{c|}{ Intra-CV } & \multicolumn{2}{c|}{ Pós-CV } & \multicolumn{2}{c}{ Total (N-\%) } \\
\hline Presença & N-189 & $\%-61.8$ & N-42 & $\%-13.7$ & N-75 & $\%-24.5$ & 306 & 66.2 \\
\hline Ausência & N-10 & $\%-6.4$ & N-75 & $\%-48.1$ & N-71 & $\%-45.5$ & 156 & 33.8 \\
\hline Total & N-199 & $\%-43.1$ & N-117 & $\%-25.3$ & N-146 & $\%-31.6$ & \multicolumn{2}{|c}{ N-462 } \\
\hline
\end{tabular}

Puderam ser assinalados, entretanto, casos em que, mesmo com a presença do elemento proclisador, o pronome clítico aparecia na posição V1 cl V2 ou na posição V1 V2 cl - como mostra o exemplo 12 abaixo, com o determinado atrator sublinhado.

(12) [...] um povo que se nutria principalmente de molluscos não devia estabelecer-se no interior [...]. (A Província de São Paulo, São Paulo, 1880 - gênero Artigo)

Por outro lado, encontraram-se dados em que os pronomes clíticos estavam em posição cl V1 V2 mesmo com a ausência de elementos proclisadores. Os exemplos, abaixo, indicam esse contexto.

(13) Em confirmação d'este asserto me foi mostrado este additamento [...]. (O Estado de São Paulo, São Paulo, 1890 - gênero Carta do Leitor) 
(14) Todos os negocios se podem tratar directamente [...]. (O Estado de São Paulo, São Paulo, 1895 - gênero Anúncio)

Os exemplos, acima descritos (13 e 14), revelaram que ao lado das prescrições estabelecidas pela norma padrão vigente naquela época - e que ainda vigora atualmente -, no que concerne à colocação pronominal em contextos de complexos verbais, também, coexistiam outros usos. O exemplo 12 (e outras sentenças na mesma direção) foi de encontro à norma padrão, já que não seguiram a recomendação de que, com locuções verbais, utiliza-se próclise ao verbo auxiliar, quando presentes as condições exigidas para a anteposição do pronome a um só verbo, como é o caso da presença do elemento proclisador. Quanto ao exemplo 13, sem a presença de atratores do pronome, haveria ainda a possibilidade de o pronome átono aparecer entre os verbos, em posição V1 cl V2, uma vez que a colocação posposta a V2 no particípio não é permitida. Por fim, no exemplo 14, também ocorreu uso diverso ao que segue o caráter normativo, dado que, em orações com verbo principal no infinitivo ou no gerúndio, sem a presença do elemento proclisador, preceitua-se a ênclise ao verbo principal.

Os resultados referentes à colocação pronominal na oração de acordo com o tipo de complexo verbal estão distribuídos na Tabela 9.

Tabela 9 - Número de ocorrências e percentuais da colocação dos pronomes clíticos em complexos verbais, de acordo com o tipo de complexo verbal

\begin{tabular}{l|c|c|c|c|c|c|c|c}
\hline \multicolumn{1}{c|}{ Tipo de CV } & \multicolumn{2}{|c|}{ Pré-CV } & \multicolumn{2}{c|}{ Intra-CV } & \multicolumn{2}{c|}{ Pós-CV } & \multicolumn{2}{c}{$\begin{array}{c}\text { Total } \\
\text { (N-\%) }\end{array}$} \\
\hline $\begin{array}{l}\text { Passiva do } \\
\text { verbo ser }\end{array}$ & N-34 & $\%-87.2$ & N-5 & $\%-12.8$ & N-0 & $\%-0$ & 39 & 8.4 \\
\hline $\begin{array}{l}\text { Tempos } \\
\text { compostos } \\
\begin{array}{l}\text { e estruturas } \\
\text { aspectuais }\end{array}\end{array}$ & N-56 & $\%-56$ & N-31 & $\%-31$ & N-13 & $\%-13$ & 100 & 21.6 \\
\hline $\begin{array}{l}\text { Perífrases } \\
\text { verbais modais } \\
\text { e aspectuais }\end{array}$ & $\mathrm{N}-52$ & $\%-33.5$ & $\mathrm{~N}-24$ & $\%-15.5$ & $\mathrm{~N}-79$ & $\%-51$ & 155 & 33.5 \\
\hline $\begin{array}{l}\text { Complexos } \\
\text { bioracionais }\end{array}$ & $\mathrm{N}-57$ & $\%-33.7$ & $\mathrm{~N}-58$ & $\%-34.3$ & $\mathrm{~N}-54$ & $\%-32$ & 169 & 36.5 \\
\hline \begin{tabular}{l} 
Total \\
\hline
\end{tabular} & $\mathrm{N}-199$ & $\%-43$ & $\mathrm{~N}-118$ & $\%-25.5$ & $\mathrm{~N}-146$ & $\%-31.5$ & $\mathrm{~N}-463$ \\
\hline
\end{tabular}


Quanto ao tipo passiva do verbo ser, prevaleceu a posição cl V1 V2, com índice de $87.2 \%$. Na sequência, foi registrada a preferência pela posição V1 cl V2. Pela forma verbal de V2, nessas construções, ser a do particípio, e pela vigorosa restrição imposta à posposição do pronome a essa forma verbal, não houve nenhum registro do pronome clítico em posição V1 V2 cl, quando adjungido a esse tipo de complexo. Dos 34 dados em posição cl V1 V2, em 28 houve a presença, na oração, de algum elemento proclisador.

Com o tipo tempos compostos e estruturas aspectuais, os pronomes clíticos, de modo mais acentuado, posicionaram-se antepostos ao verbo. Dos 56 dados observados, 45 apresentaram V2 em particípio, 6 em infinitivo e 5 em gerúndio. Ainda, quanto a esses registros, em 52 foi verificada a presença de algum elemento proclisador.

Quando os clíticos estavam adjungidos a complexos verbais do tipo perifrases verbais modais e aspectuais, tais pronomes foram motivados a ocupar a posição V1 V2 cl, ainda que houvesse em algumas orações a presença do elemento proclisador, como averiguado em 42 dados, de um total de 79. Os resultados encontrados nessa posição, e com esse tipo de complexo verbal, apresentaram-se todos com V2 na forma de infinitivo.

Finalmente, referente ao tipo complexos bioracionais, observaram-se índices de frequência bastante equilibrados entre as três referidas variantes. Os pronomes clíticos apareceram 33,7\% na posição cl V1 V2, 34,3\% na posição V1 cl V2 e, na posição V1 V2 cl, 32\%. Do total de 57 dados, em posição cl V1 V2, em 55 houve a presença de algum elemento proclisador e, nos 57 registros, V2 está sob a forma de infinitivo. Os dados em posição V1 clV2, numa soma de 58, apresentaram-se todos com V2 no infinitivo, assinalando-se algum atrator em apenas dezessete orações. O clítico pronominal foi encontrado em posição V1 V2 cl 54 vezes, estando V2 sob a forma de infinitivo em todos os registros; enquanto o elemento proclisador, este esteve presente em 25 orações.

De acordo com os resultados apresentados, pôde-se dizer que as correlações entre esta variável e as variáveis forma verbal de V2, principalmente, e presença ou ausência de atrator foram relevantes. 


\section{Palavras finais}

Constatou-se, referente aos condicionamentos extralinguísticos, maior significância da interferência da variável gênero textual na colocação pronominal.

A hipótese, relacionada ao comportamento dos clíticos pronominais nos gêneros do jornal, de que nos textos jornalísticos possam circular construções linguísticas conservadoras e inovadoras, privilegiando-se, respectivamente, ora as posições pós-verbal, em contextos de um único verbo, e pré-complexo verbal, em contextos de mais de um verbo, ora as posições pré-verbal e intra ou pós-complexo verbal, diretamente estabelecidas segundo qual gênero textual determinado texto materializa, fez que houvesse detalhada caracterização dos gêneros textuais. Os resultados obtidos a partir dessa análise, envolvendo gêneros textuais, mostraram-se bastante significativos, revelando a pertinência da consideração das relações entre variação, mudança linguística e gêneros textuais na investigação dos processos ocorridos na história de uma língua. Entretanto, percebeu-se, ainda, a necessidade de um maior aprofundamento em busca de traços que melhor definam as naturezas dos gêneros textuais, uma vez que ainda são poucas as discussões, no meio acadêmico, que retratam essa questão, a fim de que sejam somadas, cada vez mais, informações que possam auxiliar na interpretação, mais fidedigna, dos resultados.

Considerando-se a subamostra composta para a análise das variáveis independentes linguísticas, quanto aos clíticos pronominais adjuntos a lexias verbais simples, destacaram-se os resultados provenientes das variáveis presença ou ausência de elemento proclisador na oração, formas verbais e verbo hospedeiro em início, ou não início, absoluto na oração. Quanto aos clíticos pronominais adjungidos a complexos verbais, discutiram-se os dados referentes às variáveis forma verbal de V2, presença ou ausência de elemento proclisador na oração e tipo de complexo verbal.

Os dados puderam revelar, ainda que somente por um número restrito de traços inovadores perante o conservadorismo da norma 
padrão, uma das características de qualquer língua, a de que é ilimitadamente heterogênea, apresentando um conjunto de normas linguísticas e o inevitável contato entre essas muitas normas, distintas segundo aspectos sociais, culturais e ideológicos e, também, questões referentes às situações comunicativas.

Desse modo, ainda que se tenha assegurado, por parte das elites brasileiras, principalmente na segunda metade do século XIX, a criação de um projeto político que visava à construção de uma nação que se aproximasse, ao máximo, das realidades vivenciadas nos países europeus, estendendo-se, também, essa obsessão à língua materna, buscando-se uma identidade linguística além-mar, observou-se, já naquela época, através dos usos dos falantes, características próprias do português brasileiro.

Outro ponto a ser destacado é a relevância do uso de textos jornalísticos como fonte de dados para o estudo de processos de variação e mudança linguísticas, confirmando-se, como exposto neste estudo, a sua riqueza para que seja observada a mútua ligação entre o que "se deve dizer", resultado da norma linguística prescritiva, a de prestígio, e o que "é dito", produto da(s) norma(s) objetiva(s), intrínsecas aos falantes.

Concluiu-se, portanto, que, a partir do levantamento de todas as variáveis - extralinguísticas e linguísticas - discutidas no correr deste estudo, a presente investigação pôde contribuir com a descrição da variedade do Português Paulista, assinalando, concomitantemente, um avanço em relação aos estudos já existentes sobre esta mesma temática - a posição dos clíticos pronominais.

\section{Referiencias bibliográficas}

ALKMIM, T. M. Sociolingüística - Parte I. In: MUSSALIM, F; BENTES, A. C. Introdução à linguística - domínios e fronteiras. vol. 1. São Paulo: Cortez, 2001. p.22-47.

BAKHTIN, M. Estética da criação verbal. São Paulo: Martins Fontes, 1992 [1979]. 
BIAZOLLI, C. C. Clíticos pronominais no português de São Paulo: 1880 a 1920 - uma análise sócio-histórico-linguística. Araraquara, 2010. 230 fls. Dissertação (Mestrado em Linguística e Língua Portuguesa) - Faculdade de Ciências e Letras, Universidade Estadual Paulista, Araraquara, 2010.

BONINI, A. Veículo de comunicação e gênero textual: noções conflitantes. DELTA - Revista de Documentação de Estudos em Lingüística Teórica e Aplicada, São Paulo, v. 19, n. 1, p.65-89, 2003.

Em busca de um modelo integrado para os gêneros do jornal. In: CAVALCANTE, M. M.; BRITO, M. A. P. (org.). Gêneros textuais e referenciação. CD-rom. Fortaleza: PPGL/UFG, 2004.

Os gêneros do jornal: questões de pesquisa e ensino. In: KARWOSKI, A. M.; GAYDECZKA, B.; BRITO, K. S. (orgs.). Gêneros textuais: reflexões e ensino. 2. ed. Rio de Janeiro: Lucerna, 2006. p.57- 71.

FIORIN, L. J. Os gêneros do discurso. In: Introdução ao pensamento de Bakhtin. São Paulo: Ática, 2008. p.60-76.

LABOV, W. The Social Stratification of English in New York City. Washington. D. C.: Center for Applied Linguistics, 1966.

LABOV, W. Building on Empirical Foundations. In: LEHMANN, W.; MALKIEL, Y. (org.). Perspectives on historical linguistics. Philadelphia: John Benjamins Publishing Company, 1982.

. Principles of linguistic change. Vol. 1: Internal factors. Cambridge: Blackwell, 1994.

Principles of linguistic change. Vol. 2: Social factors. Cambridge: Blackwell, 2001.

Padrões sociolingüísticos. São Paulo: Parábola, 2008 [1972].

MARCUSCHI, L. Gêneros textuais: definição e funcionalidade. In: DIONISIO, A. P.; MACHADO, A. R.; BEZERRA, M. A. (orgs.). Gêneros textuais e ensino. 4. ed. Rio de Janeiro: Lucerna, 2005. p.19-36. Gêneros textuais: configuração, dinamicidade e circulação. In: KARWOSKI, A. M.; GAYDECZKA, B.; BRITO, K. S. (orgs.). Gêneros textuais: reflexões e ensino. 2. ed. Rio de Janeiro: Lucerna, 2006. p.23-36.

Produção textual, análise de gêneros e compreensão. São Paulo: Parábola, 2008.

SANKOFF, D.; TAGLIAMONTE, S.; SMITH, E. Goldvarb X: A variable rule application for Macintosh and Windows. Toronto: Department of Linguistics, University of Toronto, 2005. 
84 DANIEL SOARES DA COSTA (ORG.)

WEINREICH, V.; LABOV, W.; HERZOG, M. Fundamentos empíricos para uma teoria da mudança lingüística. São Paulo: Parábola, 2006 [1968]. 


\title{
3 \\ ESTUDO DIACRÔNICO DO PRETÉRITO PERFEITO NO PORTUGUÊS DO BRASIL
}

\author{
Juliana Bertucci Barbosa ${ }^{1}$
}

\section{Introdução²}

\begin{abstract}
"O passado é por definição, um dado que coisa alguma pode modificar. Mas o conhecimento do passado é uma coisa em progresso, que ininterruptamente se transforma e se aperfeiçoa."
\end{abstract}

$(\text { Marc Bloch })^{3}$

Neste capítulo, dando continuidade aos estudos pautados em corpus, faremos uma "viagem diacrônica" na história da variedade brasileira, buscando realizar um estudo descritivo-comparativo das possíveis variações e/ou mudanças nos usos do Pretérito Perfeito Simples (PPS) e no Pretérito Perfeito Composto (PPC) no Português Brasileiro (PB) escrito desde a sua origem, século $\mathrm{XVI}^{4}$, até o

1 Professora da Universidade Federal do Triângulo Mineiro.

2 Neste capítulo, apresentamos resultados parciais da minha tese defendida na Unesp, Campus de Araraquara, no ano de 2008 e indicada ao Prêmio Capes de Teses no ano de 2010.

3 Bloch, M. Introdução à história. Lisboa: Publicação Europa-América, p. 55.

4 Cabe relembrar que as manifestações escritas no século XVI ainda não constituíam PB, e nem sempre eram escritas por brasileiros, por isso, adotamos como critério selecionarmos apenas textos escritos no Brasil por portugueses 
contemporâneo, século XX. É por meio de uma análise diacrônica que podemos identificar o momento de aparecimento (ou morte) de uma determinada variante linguística, e/ou suas variações de usos, que podem implicar em uma mudança.

Com base, então, nos princípios de variação e mudança, verificaremos se houve uma especialização no emprego da forma composta ou se ela nunca possuiu o mesmo uso encontrado em outras línguas românicas (valor de pretérito e valor aspectual perfectivo/ acabado). Dessa forma, visamos testar a nossa hipótese de caracterização do PPC e do PPS no qual atribuímos a essas duas formas a mesma definição temporal e as diferenciamos quanto aos seus valores aspectuais.

\section{Estudos diacrônicos: o estudo da língua em tempo real}

O foco principal da Linguística Histórica, que, está estritamente relacionada com a Sociolinguística, é o estudo das mudanças que ocorrem nas línguas ao longo do tempo. Weinreich, Labov e Herzog (1968) demonstram em sua obra que a Linguística Histórica envolve todos os estudos que tratam do funcionamento das línguas a partir de dados datados e localizados. Outra obra clássica, Sincronia, diacronia e história, de Coseriu (1979), aponta como históricos todos os estudos linguísticos que tratam do funcionamento sincrônico e do "constituir-se" diacrônico das línguas.

O estudo histórico da língua pode compreender vários aspectos, permitindo a realização de comparações, como:

a. entre estágios sucessivos de línguas históricas geneticamente relacionadas (ou não);

(ou brasileiros) para compor o nosso corpus desse século. A partir do século XVII, selecionamos apenas os textos escritos por brasileiros. 
b. entre estágios sucessivos de uma mesma língua histórica -como é o caso desta tese;

c. entre variantes dialetais (geográficas, sociais, de registro) de uma língua;

d. entre gerações conviventes de usuários, como na teoria de variação e mudança laboviana, de uma língua, utilizando o recurso do tempo aparente em contraposição com o tempo real. (Silva, 2004, p.156)

Segundo Paiva e Duarte (2003, p.181), a pesquisa da mudança em tempo real, ao longo do tempo, possibilita reconhecer de maneira eficiente, principalmente, dois tipos de mudanças (p.181):

a. as que aparecem de forma gradual em uma comunidade linguística;

b. as que caracterizam a história do comportamento linguístico do indivíduo ao longo da sua vida.

O estudo da mudança em tempo real permite não apenas localizar, como ressaltado na Introdução deste capítulo, o momento de aparecimento (ou morte) de uma determinada variante linguística, mas também "verificar a regularidade na ação dos princípios que regem a variação e subjazem à implantação da mudança”" (ibidem, p.182), por isso, neste trabalho, avaliaremos e compararemos os usos e funções do Pretérito Perfeito Simples (PPS) e do Pretérito Perfeito Composto (PPC) no Português Brasileiro (PB), em diversos pontos do tempo (do século XVI ao XX) em textos escritos mais formais e menos formais. Como já afirmava Labov (1972), a compreensão dos fatos passados pode auxiliar na compreensão de fatos no presente e vice-versa.

Porém, o estudo diacrônico envolve alguns problemas, entre eles a ausência de falantes da língua em um tempo passado. Isso leva, como foi o caso desta pesquisa, o linguista a estudar amostras da língua escrita, analisando documentos considerados representativos de uma determinada época, partindo do pressuposto de que 
neles se encontram registros de variações e/ou mudanças de uma forma - no nosso caso, as formas simples e composta do Pretérito Perfeito - em um dado momento sincrônico em relação a outro.

Labov (1994, p.11) faz um comentário sobre esses documentos representativos de uma dada época que chegam a nossas mãos e são utilizados em corpus para pesquisas diacrônicas, alertando: "os fragmentos da documentação escrita que permanecem são os resultados de acidentes históricos que vão além do controle do investigador". É por esse motivo que esse sociolinguista define o estudo da mudança no tempo real como a "arte de fazer o melhor uso dos maus dados".

Com base nessas discussões, trabalharemos sob a perspectiva da Linguística Histórica e da Teoria da Variação e Mudança Linguística, coadunando-nos com Silva (2004, p.156), no seu sentido estrito: o da mudança de uma língua em tempo real de longa duração.

\section{Pretérito perfeito: sucintas definições semânticas}

Para realizar a análise das formas do Pretérito Perfeito Simples (PPS) e do Pretérito Perfeito Composto (PPC) do modo indicativo no Português Brasileiro, embasamo-nos teoricamente em estudos semânticos sobre as categorias tempo e aspectos verbais. Além disso, partimos do princípio de que as interpretações dos tempos verbais no sintagma, na frase e no texto são solidárias e consideramos como núcleo sintático-semântico da frase, o verbo. Admitimos também que as categorias tempo e aspecto não estão apenas morfologicamente amalgamadas no Português, mas também se relacionam estruturalmente do ponto de vista semântico, ainda que muitas vezes seja possível identificar a predominância de uma delas na realização dos enunciados.

Assim, para este capítulo, entendemos como tempo uma categoria dêitica que expressa relações de anterioridade ou simultaneidade entre três momentos (Momento da Fala-MF, Momento do Evento - ME, e o Momento de Referência - MR) (Corôa, 1985; Barbosa, 2008); e como aspecto uma categoria não dêitica, que quantifica o 
evento expresso pelo verbo ou exprime a constituição interna de fases, momentos ou intervalos de tempo que se incluem nesse evento (Corôa, 1985; Barbosa, 2008).

Coadunando com Corôa (1985) e Barbosa (2003, 2008) - ambas fundamentadas nos estudos de Reichenbach (1980) - atribuímos a cada tempo verbal do Português uma definição única e não ambígua ${ }^{5}$, centrando-se na interpretação fornecida pelo morfema modo-temporal do verbo e no auxiliar + verbo principal. Partimos das possibilidades combinatórias dos três pontos temporais reichenbachianos - momentos do evento (ME), da fala (MF) e da referência (MR): ME é o mais concreto, refere-se ao o intervalo de tempo em que decorre o processo, evento, ação ou estado descrito; o MF é o momento da enunciação, ligado àquele da comunicação; e o MR, o mais complexo desses construtos, pode ser um momento mais preciso ou menos preciso, que marca a perspectiva do falante em relação ao evento (Corôa, 1985, p.42)

Desse reconhecimento da não concretude dos momentos ${ }^{6}$ resulta uma grande riqueza de possibilidades para o aproveitamento do esquema de Corôa (1985) na explicação dos diferentes usos e valores dos tempos verbais. Aceitando-se a não concretude dos momentos, elimina-se a necessidade de derivar contextualmente a sua interpretação.

Barbosa (2008), em sua pesquisa, demonstra que tanto o PPS como o PPC devem receber a mesma definição temporal, ME

5 Em vista disso, Barbosa (2008) argumenta que a interpretação semântica do sintagma verbal nem sempre está subordinada à interação com adjuntos - por exemplo, na frase "Eu sou você amanhã", de um antigo comercial de uísque -, e prefere não adotar a hipótese da polissemia, buscando outras representações mais abstratas para as formas verbais.

6 Os momentos são conjuntos de pontos ou intervalos de tempo, não sendo preciso haver coincidência extensional entre ME, MR e MF para que sejam considerados simultâneos; basta que haja um ponto de coincidência. Por exemplo, nos casos de presente histórico ou dramático, o MR se amplia, deslocando-se para o passado e "abrangendo-o de tal modo que tanto o MF como o ME se incluem no MR. [...] ME e MF não têm necessariamente pontos em comum, mas ambos o têm como o MR" (Corôa, 1985, p.47). 
- MR, MF, ${ }^{7}$ e postula que é possível distinguir os pretéritos do ponto de vista aspectual. Para tanto, aproveitou a conceituação de Corôa (1985, p.74), segundo a qual o aspecto é a quantificação dos subeventos de um evento. Um subevento é qualquer dos estágios intermediários de um evento, inclusive o inicial e o terminal. O Perfeito Simples se opõe ao Imperfeito, porque no primeiro todos os estágios se realizam no intervalo de tempo compreendido pelo evento em questão e, no segundo, ao menos um subevento se localiza nesse intervalo de tempo. Conciliando a distinção de Corôa (1985) com a função de pluralização de eventos atribuída por Ilari (2001) ao PPC, podemos dizer que no Perfeito Composto mais de um (sub)evento está necessariamente incluído no Intervalo de Tempo (doravante $I_{t}$ ). Se a interação do auxiliar com a base resulta em interpretação iterativa, temos a pluralidade de eventos; numa interpretação durativa, os produtos são subeventos plurais. Essa concepção ajuda a entender porque os (sub)eventos expressos pelo PPC podem ser interpretados como estendendo-se até o presente ou futuro: o fato de alguns estágios se localizarem no intervalo de tempo em questão deixa aberta a possibilidade de que outros estágios venham a se realizar fora desse $I_{t}$.

Dessa forma, como se pôde verificar, a análise aspectual permite distinguir semanticamente o PPS do PPC. Após esta breve introdução teórica, temos condições de discutir se tal distinção é suficiente para explicar os usos desses dois tempos no Português Brasileiro e se essas características das duas formas verbais aqui estudadas estão presentes no PB desde o século XVI.

\section{A análise dos dados pautados em corpus: o PPC e o PPS no português do Brasil}

Para investigarmos os usos do PPC e do PPS do Português do Brasil do século XVI ao XX montamos um corpus com textos escri-

7 As vírgulas indicam simultaneidade e os hífens, anterioridade. 
tos pertencentes a dois grupos - um mais e outro menos formal escritos em PB do século XVI ao XX. Após a montagem do corpus, selecionamos as ocorrências das formas verbais simples e composta do Pretérito Perfeito do modo indicativo.

Foram, portanto, selecionadas 3.129 ocorrências de Pretérito Perfeito do nosso corpus do PB, distribuídas nas formas simples e composta, como mostra a Tabela 1 abaixo:

Tabela 1 - Ocorrências do Pretérito Perfeito no PB do século XVI ao XX

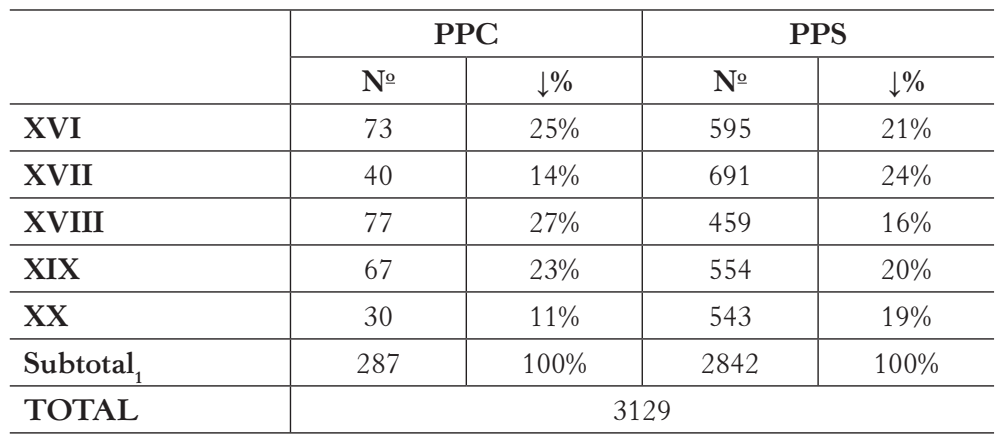

Analisamos essas ocorrências de acordo com os seguintes grupos de fatores ${ }^{8}$ : (a) tempo real; (b) grau de formalidade dos textos; (c) telicidade do verbo (télico vs. atélico); (d) valor semântico (iterativo, durativo e predominantemente perfectivo); (e) presença ou ausência de adjunto adverbial. Em seguida, fizemos o cruzamento do fator "tempo real" com os demais, para melhor interpretarmos os dados e estabelecermos o percurso do PPC e do PPS no Português Brasileiro. Neste capítulo, apresentaremos somente os resultados mais relevantes de alguns desses grupos de fatores.

Confrontando as ocorrências de PPC e PPS em cada século (Tabela 1) - fazendo uma leitura horizontal -, verificamos que, como esperado, desde o século XVI, a forma composta possui baixa ocorrência em relação à forma simples.

8 Utilizamos, para auxiliar a nossa análise, o pacote de programas estatísticos Varbul. 
Como pudemos observar na Tabela 1, o PPC manteve, do século XVI ao XIX, uma porcentagem de ocorrências em torno de $20 \%$ (variando entre $25 \%$ a $27 \%$ ), com exceção do século XVII em que seu índice de ocorrências é de 14\%. Acreditamos que isso ocorre devido às próprias restrições semânticas do Pretérito Perfeito Composto (PPC), já que a forma composta já aparece como um operador quantificacional nesse período, ou seja, os textos que compõem a amostra do século XVII não possuíam contextos em que era necessário o emprego do PPC.

Também verificamos que no século XX a rentabilidade da forma composta cai para 11\%, indicando-nos que o PPC no Português Brasileiro (PB), aparentemente, sofre um decréscimo em seu uso. Esse resultado pode estar associado ao fato de que o PPC foi se especializando como um operador quantificacional, deixando de expressar exclusivamente perfectividade e passando a exprimir predominantemente iteração e duração; o decréscimo de seu uso no século XX, então, poderia ser justificado devido às suas restrições semântico-discursivas, que se tornaram mais patentes. Entretanto essa hipótese só pode ser confirmada com a análise dos outros fatores.

Já as ocorrências do PPS (Tabela 1), mostra-nos que a forma simples manteve seu percentual de ocorrências equilibrado no período de tempo que compreende a nossa análise, do século XVI ao XX, variando entre $16 \%$ a 24\%. O maior rendimento dessa forma aparece no século XVII (24\%), ocasionada devido ao maior número de trechos narrativos nos textos que compõem o corpus dessa época, como mostram os fragmentos ${ }^{9}$ abaixo:

(01) Meu amantíssimo padre Antônio Maria. (...) recebi outras duas cartas, a que não respondi até agora por falta de embarcação

9 Os exemplos deste capítulo foram extraídos de um corpus organizado especificamente para esta pesquisa, com cartas (doravante CO) e discursos (doravante O) escritos no período de 1500 a 2000 no Brasil. Esses documentos foram digitados pela pesquisadora e estão disponíveis no Laboratório de Lexicografia da Unesp, campus de Araraquara. 
ou por não ter notícia dela. Agora o farei, não tão largamente como quisera, pela grande consolação que recebo com falar com V. M. [...] Hoje faz oito dias que degolaram no nosso terreiro o fidalgo que de lá veio preso pelas mortes de sua mulher e filhas, e foi a sua cabeça para ser posta no lugar do delito. Queira Deus que este exemplo faça algum fruto; mas que se pode esperar de uma morte quando tantas e tão repetidas não bastaram para emendar os que ainda se não acham livres totalmente do perigo? $(\mathrm{CO}, 1687)$

Essa análise do tempo real pode ser correlacionada à análise dos valores semânticos expressos pelas formas simples e compostas. Observemos os resultados encontrados no PPC:

Tabela 2 - Valores aspectuais do PPC no PB: século XVI ao XX

\begin{tabular}{l|c|c|c|c|c|c|c|c}
\hline \multirow{2}{*}{} & \multicolumn{8}{c}{ PPC } \\
\cline { 2 - 9 } & \multicolumn{2}{|c|}{ Perfectivo } & \multicolumn{2}{c}{ Iterativo } & \multicolumn{2}{c}{ Durativo } & \multicolumn{2}{c}{ Total } \\
\cline { 2 - 9 } & № & $\rightarrow \%$ & № & $\rightarrow \%$ & № & $\rightarrow \%$ & № & $\rightarrow \%$ \\
\hline XVI & 37 & $51 \%$ & 30 & $42 \%$ & 5 & $7 \%$ & 73 & $100 \%$ \\
\hline XVII & 13 & $33 \%$ & 26 & $65 \%$ & 1 & $2 \%$ & 40 & $100 \%$ \\
\hline XVIII & 18 & $23 \%$ & 52 & $68 \%$ & 7 & $9 \%$ & 77 & $100 \%$ \\
\hline XIX & 3 & $5 \%$ & 45 & $67 \%$ & 19 & $28 \%$ & 100 & $100 \%$ \\
\hline XX & 0 & - & 18 & $60 \%$ & 12 & $40 \%$ & 30 & $100 \%$ \\
\hline
\end{tabular}

No Tabela 2 podemos observar que o PPC aparece no século XVI com $51 \%$ de ocorrências com valor exclusivamente perfectivo em relação aos outros valores aspectuais. Essa porcentagem vai diminuindo ao longo dos séculos (33\% no XVII, 23\% no XVIII e 5\% no XIX) até chegar ao século XX sem nenhuma ocorrência da forma composta expressando estritamente valor de um evento "acabado". Isso nos mostra que o PPC foi gradativamente se especializando no $\mathrm{PB}$, tornando-se um operador aspectual (iteração e duração).

Para ilustrar as ocorrências do PPC com valor apenas perfectivo, observemos os seguintes exemplos: 
(02) Trabalhamos de saber a lingua delles e nisto o padre Navarro nos leva vantagem a todos. Temos determinado ir viver com as aldeias, como estivermos mais assentados e seguros, e aprender com elles a lingua e il-os doutrinando pouco a pouco. (O, 1549)

(03) eu as que poderei dar a V. Ex $x^{\mathrm{a}}$ minhas são de que tenho chegado a esta Capital no dia 31 de outubro $(\mathrm{O}, 1769)$

Nesses exemplos, as formas compostas podem ser substituídas pela forma simples, sem alterar o sentido do texto:

(02') Trabalhamos de saber a lingua delles e nisto o padre Navarro nos leva vantagem a todos. Já DETERMINAMOS ir viver com as aldeias, como estivermos mais assentados e seguros, e aprender com elles a lingua e il-os doutrinando pouco a pouco. (O, 1549)

(03') [...] eu as que poderei dar a V. Ex ${ }^{\mathrm{a}}$ minhas são de que CHEGUEI a esta Capital no dia 31 de outubro $(\mathrm{O}, 1769)$

É importante destacar que, no século XIX, as três ocorrências do PPC apenas com valor de um evento que está concluído dentro de um intervalo de tempo (perfectivo) foram acompanhadas do adjunto adverbial "já"; ou seja, a combinação PPC+adjunto adverbial (já) resultou em uma interpretação exclusivamente perfectiva, como em:

(04) Meu caro Barão já lhe tenho escrito diversas cartas mas ainda não tive o prazer de reconhecer nas que recebo da Europa a sua caligrafia. (CO, 1881)

Isso indica que, já no século XIX, o PPC era utilizado preferencialmente expressando iteração e duração. É importante salientar que a combinação PPC+adjunto adverbial (já) também aparece nos século XVI, XVII e XVIII: 
(05) Por outras cartas vos tenho já escrito de minha disposição, a qual cada dia se renova, de maneira que nenhuma diferença ha de mim a um são, ainda que algumas vezes não deixo de ter algumas relíquias das enfermidades passadas. $(\mathrm{CO}, 1554)$

(06) Já tenho advertido a Vossa mercê se não intrometa na jurisdição dos juizes câmaras dessa Capitania não embaraçando as acusações e diligências da justiça, porque de qualquer procedimento desta têm as partes o recurso ordinário de que devem usar quando se achem agravadas, agora se queixa o juiz e oficiais da Câmara da vila da Vitória, do excesso com que Vossa Mercê se houve acerca de uns barreiros e como este procedimento é incivil e extraordinário; advirto a Vossa Mercê se abstenha destes excessos por serem contra o serviço de Sua Majestade. (CO, 1751)

No Tabela 2 também podemos constatar que o PPC com valor iterativo ocorre com menor índice no século XVI (42\%), aumentando a partir do século XVII para índices que ficam entre 60\% e 68\%. O valor durativo também aparece desde o século XVI (7\%), porém, ao contrário do iterativo, torna-se mais produtivo somente nos séculos XIX (28\%) e XX (40\%). O uso mais frequente da forma composta com valor aspectual predominantemente iterativo no século XX (60\%) confirma as hipóteses de Boléo (1936), Viana (1901) e Ilari (2001) sobre os usos da forma composta:

(i) “o passado composto exprime iteração" (Ilari, 2001, p.134);

(ii) o "PC assume eventualmente valor de continuidade [duração]" (ibidem, p.143). Esse "eventual” valor aspecutal durativo do PPC, como veremos, está relacionado, como já apontava Castilho $(1966,1968)$, ao semantema do verbo (no caso, a telicidade verbal).

Assim, podemos afirmar que os resultados acima expostos comprovam que o PPC foi se estabelecendo ao longo do tempo no PB como um operador aspectual, deixando de expressar perfectividade e passando a expressar valores [+genéricos] e [+indefinidos]. 
Cabe ressaltarmos que, ao analisarmos essas ocorrências, o valor exclusivamente perfectivo do PPC era explícito, como no exemplo abaixo:

(07) Tambem mepareseu dizer a vossa excelenca que he muito nesesario que vossa excelenca mande dar ademe nistrasam aos religiozos do Carmo do Convento de mogi por estar no destrito ou a outro qualquer que vossa excelenca for servido, para que posam por hú religiozo capaz para o ademenistrar e o doutrinar por que de prezente estam morendo sem com fisam e sacramentos por ser distantes dehuã vila eoutra e como tem falesido o Cappitam mor da dita aldea hé nesesario que vossa excelenca sendoser vido mande prover outro eomais capaz que ha hé hû por nome Sebastião da Silva que he oportador desta eser muito zelozo para as couzas da aldea. $(\mathrm{O}, 1720)$

Nesse exemplo o próprio verbo principal "falecer" (classificado como télico) não permite uma interpretação iterativa ou durativa, sendo possível a substituição da forma composta pela simples:

(07’) [...] Como FALECEU o Cappitam mor da dita ALdea hé nesesario que vossa excelenca sendoser vido mande prover outro eomais Capaz $[\ldots]$

Cabe ressaltar que, em situações em que o PPC é usado com valor predominantemente perfectivo, o seu uso não parece ser idêntico ao PPS; em alguns casos é possível interpretar que o falante quer, além de marcar um "evento acabado" dentro de um intervalo de tempo, também enfatizar o término do evento, como em:

(08) Até agora sempre tenho estado em Piratininga, que é a primeira aldeia de Índios, que está 10 léguas do mar, como em outras cartas tenho escrito, em a qual estarei por agora, porque é terra mui boa; e porque não tinha purgas nem regalos de enfermaria. (CO, 1554) 
Em que podemos entender como "PPS+já": :

(08') Até agora sempre tenho estado em Piratininga, que é a primeira aldeia de Índios, que está 10 léguas do mar, como em outras cartas JÁ ESCREVI, em a qual estarei por agora, porque é terra mui boa; e porque não tinha purgas nem regalos de enfermaria. (CO, 1554, destaque e alteração de texto nossa)

Entretanto, em outros casos tivemos dificuldades de estabelecer se o PPC estava expressando predominante valor perfectivo ou se estava, juntamente com esse valor, exprimindo também iteração e duração, como ocorre no Português Brasileiro contemporâneo. Isso se deu, principalmente, em textos escritos em séculos anteriores, e embora recorrêssemos ao contexto (mais amplo), nem sempre conseguimos chegar a uma conclusão exata, como ocorre em:

(09) [...] os favores que devem esperar de sua Real grandeza; e de que e hei de ser, assim enquanto, no Brasil estiver, como depois de me ver na Corte, um solicito instrumento; porque confesso a Vossas Mercês, que me veio, obrigadíssimo a tudo o que Vossas Mercês me escrevem. Ficará Sua Majestade entendendo, quão diversa é a opinião que o nome de Paulistas tem granjeado no conceito de alguns, contra o zelo, e a mor que mostram ter a seu Real serviço, e eu tenho experimentado em Vossas Mercês, por cujas palavras ouço a todos esses Povos, que em Vossas Mercês se representam Sua Majestade tenho proposto o único meio de se mandar o dinheiro dessas Capitanias, a esta Casa da Moeda, sem os inconvenientes das distancias, e rios que ha por terra; e da pouca segurança das embarcações da costa, para poder vir sem perigo: e é passarem por aqui as frotas do Rio de janeiro, quando, daquele porto vierem, para trazerem o dinheiro, e quando voltarem de Portugal, para o levarem. (CO1630)

(09') [...] os favores que devem esperar de sua Real grandeza; e de que e hei de ser, assim enquanto, no Brasil estiver, como depois de 
me ver na Corte, um solicito instrumento; porque confesso a Vossas Mercês, que me veio, obrigadíssimo a tudo o que Vossas Mercês me escrevem. Ficará Sua Majestade entendendo, quão diversa é a opinião que o nome de Paulistas tem granjeado no conceito de alguns, contra o zelo, e a mor que mostram ter a seu Real serviço, e eu tenho experimentado em Vossas Mercês, por cujas palavras ouço a todos esses Povos, que em Vossas Mercês se representam Sua Majestade (JÁ?) PROPUS o único meio de se mandar o dinheiro dessas Capitanias, a esta Casa da Moeda, sem os inconvenientes das distancias, e rios que ha por terra; e da pouca segurança das embarcações da costa, para poder vir sem perigo: e é passarem por aqui as frotas do Rio de janeiro, quando, daquele porto vierem, para trazerem o dinheiro, e quando voltarem de Portugal, para o levarem. (O, 1640, alteração e destaque no texto nossa)

Nesse exemplo, as interpretações aspectuais possíveis seriam:

(i) de um evento "acabado", ou seja, exprimindo uma noção exclusivamente perfectiva, ou

(ii) de um evento que se repete dentro de um intervalo de tempo (iteração).

Acabamos considerando o valor aspectual da ocorrência de PPC, do exemplo (09), como iterativa, pois o contexto da carta aponta para uma proposta que o emissor já estava fazendo por repetidas vezes. Outro exemplo seria:

(10) Vi a conta que Vossas Mercês me deram na sua carta de dez do corrente, sobre o excesso com que. Padre Fernandes Aranha procedia mandando arrancar perniciosamente as mandiocas, que Mais de 5 lavradores assistentes nas suas terras, tem plantado nelas. (CO, 1748)

Aqui também poderíamos entender "tem plantado" como uma ação que se repete ao longo de um intervalo de tempo, porém optamos por uma interpretação exclusivamente perfectiva, já que o 
contexto nos leva a entender que os lavradores já haviam plantado as mandiocas e que elas foram arrancadas "perniciosamente" pelo Padre Fernandes Aranha.

Essa dificuldade de chegarmos, em alguns casos, a uma conclusão exata de com qual valor semântico aspectual predominante o Pretérito Perfeito Composto (PPC) foi empregado em outros séculos, revela-nos que, provavelmente, essa forma passou por um período de variação, em que o seu uso com valor quantificacional já era permitido, mas ainda não estava cristalizado, pois em alguns contextos - do mesmo período - ainda podemos encontrar, claramente, o seu emprego com valor estritamente perfectivo.

Observemos agora os resultados encontrados no PPS.

Tabela 3 - Valores aspectuais do PPS no PB: século XVI ao XX

\begin{tabular}{l|c|c|c|c|c|c|c|c}
\hline \multirow{2}{*}{} & \multicolumn{9}{|c|}{ PPS } \\
\cline { 2 - 9 } & \multicolumn{2}{|c|}{ Perfectivo } & \multicolumn{2}{c}{ Iterativo } & \multicolumn{2}{c}{ Durativo } & \multicolumn{2}{c}{ Total } \\
\cline { 2 - 9 } & No & $\rightarrow \%$ & No & $\rightarrow \%$ & No & $\rightarrow \%$ & oo & $\rightarrow \%$ \\
\hline XVI & 589 & $99 \%$ & 0 & $0 \%$ & 6 & $1 \%$ & 595 & $100 \%$ \\
\hline XVII & 681 & $98,6 \%$ & 1 & $0,1 \%$ & 9 & $1,3 \%$ & 691 & $100 \%$ \\
\hline XVIII & 448 & $98 \%$ & 0 & $0 \%$ & 11 & $2 \%$ & 459 & $100 \%$ \\
\hline XIX & 542 & $98 \%$ & 0 & $0 \%$ & 12 & $2 \%$ & 554 & $100 \%$ \\
\hline XX & 538 & $99 \%$ & 1 & $0,7 \%$ & 4 & $0,7 \%$ & 543 & $100 \%$ \\
\hline
\end{tabular}

Por outro lado, na Tabela 3, vemos que o PPS exprime valor perfectivo desde o século XVI, mantendo um percentual de ocorrências constante até o século XX: 99\% no XVI, 98,6\% no XVI, 98\% no XVIII e no XIX e 99\% no XX. Isso implica que no PB o Pretérito Perfeito Simples sempre atuou com valor aspectual predominantemente perfectivo. Além disso, verificamos que, acompanhado de adjunto adverbial, o PPS também pode, a seu modo, expressar eventos plurais: o número de ocorrências do PPS exprimindo duração foi constante (variou entre 1\% e 2\% das ocorrências) nos séculos $\mathrm{XVI}$ ao XX; já com valor iterativo, encontramos apenas duas ocorrências, uma no século XVII e outra no XX. 
Outro grupo de fator que nos auxiliou a refinar a nossa pesquisa, principalmente, nos resultados relacionados aos valores aspectuais e à presença/ausência de adjunto adverbial foi a "telicidade do verbo". A tipologia verbal, muitas vezes, influencia na ocorrência de um determinado valor aspectual. Castilho (1968) aponta a telicidade verbal como um possível condicionante para manifestação dos valores aspectuais iterativos e durativos do PPC: o primeiro valor estaria relacionado a verbos télicos e o segundo, a verbos atélicos. Além disso, Comrie (1976, p.46-7) argumenta que um verbo télico associado ao PPS sempre resulta em uma noção aspectual perfectiva.

Seguindo essas motivações, testamos essas hipóteses e analisamos os verbos principais (ou verbo base) encontrados nas ocorrências do PPS e do PPS. Primeiramente, comentamos os resultados observados nas formas compostas.

Tabela 4 - O PPC e a telicidade dos verbos base nos séculos XVI ao XX

\begin{tabular}{l|c|c|c|c|c|c}
\hline \multirow{2}{*}{} & \multicolumn{6}{|c}{ PPC } \\
\cline { 2 - 7 } & \multicolumn{2}{|c}{ Télico } & \multicolumn{2}{c}{ Atélico } & \multicolumn{2}{c}{ TOTAL } \\
\cline { 2 - 7 } & № & $\rightarrow \%$ & № & $\rightarrow \%$ & № & $\rightarrow \%$ \\
\hline XVI & 65 & $\mathbf{8 9 \%}$ & 8 & $\mathbf{1 1 \%}$ & 73 & $\mathbf{1 0 0 \%}$ \\
\hline XVII & 29 & $\mathbf{7 2 \%}$ & 11 & $\mathbf{2 8} \%$ & 40 & $\mathbf{1 0 0 \%}$ \\
\hline XVIII & 56 & $\mathbf{7 3 \%}$ & 21 & $\mathbf{2 7} \%$ & 77 & $\mathbf{1 0 0 \%}$ \\
\hline XIX & 45 & $\mathbf{6 7 \%}$ & 12 & $\mathbf{3 3} \%$ & 67 & $\mathbf{1 0 0 \%}$ \\
\hline XX & 12 & $\mathbf{4 0 \%}$ & 18 & $\mathbf{6 0} \%$ & 30 & $\mathbf{1 0 0} \%$ \\
\hline
\end{tabular}

A tabela acima revela uma predominância de verbos télicos nos séculos XVI ao XIX. Esse resultado confirma a proposta de Castilho, pois o compararmos com os da Tabela 2 e verificaremos que o PPC é utilizado com maior frequência nesses séculos para expressar duas noções aspectuais: exclusivamante perfectiva (principalmente, no século XVI) e predominantemente iterativa. Para testarmos essa hipótese, realizamos o cruzamento dos fatores "telicidade" versus "valores aspectuais" nos séculos XVI ao XIX, para ilustar os resultados, apresentamos os do século XVI. 
Tabela 5 - Valores aspectuais do PPC versus telicidade do verbo principal no século XVI

\begin{tabular}{l|c|c|c|c|c|c}
\hline \multirow{2}{*}{\multicolumn{1}{c|}{ Século XVI }} & \multicolumn{6}{c}{ PPC } \\
\cline { 2 - 7 } & \multicolumn{2}{|c|}{ Télico } & \multicolumn{2}{c}{ Atélico } & \multicolumn{2}{c}{ TOTAL } \\
\cline { 2 - 8 } & № & $\rightarrow \%$ & № & № & $\rightarrow \%$ & № \\
\hline Iteração & 30 & $97 \%$ & 1 & $3 \%$ & 31 & $100 \%$ \\
\hline Duração & - & - & 6 & $100 \%$ & 6 & $100 \%$ \\
\hline Perfectivo (exclusivamente) & 35 & $97 \%$ & 1 & $3 \%$ & 36 & $100 \%$ \\
\hline
\end{tabular}

Como podemos verificar, o resultado do cruzamento no século XVI (assim como no do século XVII, XVIII e XIX) confirmou a hipótese mencionada acima: a porcentagem maior de verbos atélicos está diretamente relacionada à maior ocorrência dos valores aspectuais perfectivo e/ou iterativos expressos pela forma composta no período analisado. Vejamos dois exemplos:

(11) E se isto custar alguma cousa ele o enviará de cá em açúcar. Haja lá algum virtuoso que lho empreste, porquanto me achei nestas necessidades e com grande desejo de ver tantas almas remediadas. Escrevo isto a V. R. para a primeira embarcação mandar resposta a esta capitania de São Vicente. Os demais escreverei para ida dos navios, se me achar em parte para isso; a senão Padres e Irmãos suprirão. A uma carta, que neste São Vicente recebi, tenho já respondido. As que vierem por via da Bahia ainda não as v. È mais fácil vir de Lisboa recado a esta capitania do que da Bahia. (O, 1540)

(12) Há bastante tempo que não tem chegado a esta Bahia embarcação alguma desse Rio, nem também a sumaca em que se dizia vinham cartas de Lisboa que haviam vindo na frota, sem embargo de Vossa Senhoria não me falar nesta matéria. (CO, 1734)

Em (11), temos um caso de verbo télico - "responder (a carta)" -, que, conjugado no Pretérito Perfeito Composto, passa a expressar um valor exclusivamente perfectivo: a carta que ele, o jesuíta, já escreveu ao seu superior. No exemplo (12), temos também um 
verbo télico (chegar), que, ao ser conjugado no PPC, exprime valor iterativo: o evento "chegar" se repente dentro de um $I_{t}$.

Por outro lado, a menor ocorrência de verbos atélicos nos séculos XVI ao XIX pode ter influenciado o baixo rendimento do PPC com valor durativo, ou seja, a baixa frequência de noções durativas estaria associada ao baixo rendimento dos verbos atélicos. Já no século XX, aparentemente, temos um resultado oposto: encontramos uma maior ocorrência de verbos atélicos (60\%). Entretanto, ao cruzarmos esses resultados com os valores aspectuais das formas compostas durante esse mesmo período temos o seguinte quadro:

Tabela 6 - Valores aspectuais do PPC versus telicidade do verbo principal no século XX

\begin{tabular}{l|c|c|c|c|c|c}
\hline \multirow{2}{*}{\multicolumn{1}{c|}{ Século XX }} & \multicolumn{6}{c}{ PPC } \\
\cline { 2 - 7 } & \multicolumn{2}{|c|}{ Télico } & \multicolumn{2}{c|}{ Atélico } & \multicolumn{2}{c}{ TOTAL } \\
\cline { 2 - 7 } & № & $\rightarrow \%$ & № & № & $\rightarrow \%$ & № \\
\hline Iteração & 12 & $67 \%$ & 6 & $33 \%$ & 18 & $100 \%$ \\
\hline Duração & 0 & - & 12 & $100 \%$ & 12 & $100 \%$ \\
\hline Perfectivo (exclusivamente) & - & - & - & - & - & - \\
\hline
\end{tabular}

O cruzamento dos fatores permitiu que pudéssemos observar que a maioria das ocorrências expressando iteração (67\%) ocorreu com verbos télicos, e todas as ocorrências de PPC com valor durativo ocorreram com verbos atélicos. Esses resultados confirmam, assim, a hipótese de Castilho, como mostra os exemplos abaixo:

(13) Até aqui o nosso pobre livro tem vivido à sombra dos privilégios concedidos à imprensa e às revistas. (CO, 1926)

(14) Meu filho, tenho andado muito preocupada. Como você é jornalista e conhece muita gente de proa, quem sabe você possa interferir com elas por sua mãe? $(\mathrm{CO}, 1977)$

(15) O que tem faltado, quase sempre - no nível do estado - é uma prática coerente com aquela. $(\mathrm{O}, 1990)$ 
(16) Tenho aberto os primeiros caminhos, construído casas de trabalhadores, paióis etc. Está lindo! É adiante dos Pereiras. A roça de milho chama a atenção, é um mar de milho! O café está fora de cova. Preparo terra para feijão, uma roça monstro, de 50 alqueires! $(\mathrm{CO}, 1916)$

Em (13) e (14), temos exemplos de ocorrências de verbos atélicos+aspecto durativo, já nos exemplos (15) e (16), encontramos verbos télicos+aspecto durativo.

Os resultados da análise dos verbos flexionados no PPS foram:

Tabela 7 - O PPS e a telicidade dos verbos base nos séculos XVI ao XX

\begin{tabular}{|c|c|c|c|c|c|c|}
\hline & \multicolumn{6}{|c|}{ PPS } \\
\hline & \multicolumn{2}{|c|}{ Télico } & \multicolumn{2}{|c|}{ Atélico } & \multicolumn{2}{|c|}{ total } \\
\hline & № & $\rightarrow \%$ & № & $\rightarrow \%$ & № & $\rightarrow \%$ \\
\hline XV & 399 & $67 \%$ & 196 & $33 \%$ & 595 & $100 \%$ \\
\hline XVII & 463 & $67 \%$ & 228 & $33 \%$ & 691 & $100 \%$ \\
\hline XVIII & 327 & $71 \%$ & 132 & $29 \%$ & 459 & $100 \%$ \\
\hline XIX & 380 & $69 \%$ & 174 & $31 \%$ & 554 & $100 \%$ \\
\hline $\mathrm{XX}$ & 373 & $69 \%$ & 170 & $31 \%$ & 543 & $100 \%$ \\
\hline
\end{tabular}

Esses resultados validam as afirmações de Comrie, que sugere uma associação de valores entre o perfectivo e os verbos télicos. Como podemos perceber na Tabela 7 , em todos os séculos os verbos que obtiveram maior número de frequência foi o télico. Novamente, se fizermos um cruzamento desses resultados com os dos valores aspectuais do PPS mostrados na Tabela 3, podemos verificar que há uma predominância de praticamente $99 \%$ de valor perfectivo. Podemos ilustar a ocorrência de verbo télico+valor perfectivo, com PPS, nos exemplos (17) e (18), e verbo atélico+mais valor durativo (predominantemente), no exemplo (19) abaixo:

(17) E nós nos enganamos, hein? A gente pensou que o Carlos Lacerda tinha morrido, mas quem morreu foi outro. (CO, 1977) 
(18) Lino Não sei por onde nem como principiar; o Cenáculo confiscou-nos as chapas, as coitadinhas, tão prestimosas e serviçais, sempre nítidas e luzidias do uso ininterrupto; proibiu terminantemente a banalidade; baniu para os quintos do inferno os velhos assuntos de cartas. (CO, 1904)

(19) Sempre senti, desde o primeiro momento, quando ainda governador, a profunda, a justa revolta do povo brasileiro. (O, 1990)

Por fim, apresentamos as ocorrências das formas simples e composta, separando-as de acordo com o tipo de texto em que elas foram encontradas: textos [+] formais e textos [-] formais.

O resultado da análise do PPC nesse grupo foi o seguinte:

Tabela 8 - O PPC e o grau de formalidade dos textos nos séculos XVI ao XX

\begin{tabular}{l|c|c|c|c|c|c}
\hline \multirow{2}{*}{} & \multicolumn{9}{|c}{ PPC } \\
\cline { 2 - 7 } & \multicolumn{2}{|c|}{ [+] Formal } & \multicolumn{2}{c}{$[-]$ Formal } & \multicolumn{2}{c}{ TOTAL } \\
\cline { 2 - 7 } & № & $\rightarrow \%$ & № & $\rightarrow \%$ & № & $\rightarrow \%$ \\
\hline XVI & 41 & $\mathbf{5 6 \%}$ & 32 & $\mathbf{4 4 \%}$ & 73 & $\mathbf{1 0 0} \%$ \\
\hline XVII & 7 & $\mathbf{1 8} \%$ & 33 & $\mathbf{8 2} \%$ & 40 & $\mathbf{1 0 0} \%$ \\
\hline XVIII & 17 & $\mathbf{2 2} \%$ & 60 & $\mathbf{7 8} \%$ & 77 & $\mathbf{1 0 0} \%$ \\
\hline XIX & 33 & $\mathbf{4 9} \%$ & 34 & $\mathbf{5 1} \%$ & 67 & $\mathbf{1 0 0} \%$ \\
\hline XX & 13 & $\mathbf{4 3} \%$ & 17 & $\mathbf{5 7} \%$ & 30 & $\mathbf{1 0 0} \%$ \\
\hline
\end{tabular}

Podemos observar que, no século XVI, o PPC possui maior rendimento em textos $[+]$ formais $(56 \%)$. Podemos justificar esse maior número de ocorrências nesse tipo de texto fazendo a correlação desse resultado com os encontrados para os valores aspectuais da forma pretérita composta - em que verificamos um número elevado de ocorrências do PPC com valor exclusivamente perfectivo (51\%). Para confirmarmos essa hipótese, voltamos aos dados e constamos que o PPC teve maior número de ocorrências em textos formais, pois foi nesse tipo de texto que encontramos um número 
maior de ocorrências da forma composta expressando um valor que se perdeu ao longo dos séculos: valor aspectual estritamente perfectivo. Sendo assim, podemos afirmar que no século XVI o grau de formalidade influenciou na rentabilidade das formas compostas, já que os textos desse grupo estão mais presos às normas gramaticais e, por isso, mais resistentes à mudança (ou seja, à cristalização do uso do PPC com valores aspectuais iterativos e durativos).

Nos séculos XVII e XVIII, embora o PPC apareça com maior ocorrências em textos [-] formais, $82 \%$ e $78 \%$ respectivamente, ao retomarmos novamente os resultados da Tabela 2 (Valores aspectuais do PPC - século XVI ao XX), verificamos que nesses séculos já encontramos um maior rendimento do PPC com valores predominantemente iterativos (no XVII, 65\% e, no XVIII, 68\%). A partir desses dados podemos levantar a hipótese de que, a partir do século XVII, o grau de formalidade não vai influenciar a rentabilidade da forma composta; o que irá motivar a sua ocorrência é o contexto em que é empregada: situações em que o falante quer expressar eventos plurais de maneira genérica e indefinida, por exemplo:

a) no século XVII:

(20) Mas por que não cuidem, os que me ouvem, que nestas duas comparações da túnica de Antônio com a capa de José e vestiduras de Estêvão tenho dito alguma coisa, passemos, ou voemos mais alto, e, com a devida reverência, peçamos licença àquele benigníssimo Senhor que Santo Antônio tem nos braços, para que neste caso nos lembremos também dos seus vestidos, pois está sem eles. Pregado Cristo na cruz, em cumprimento da profecia: Diviserunt sib vestimenta meã, tomaram os soldados que tinham crucificado ao Senhor suas sagradas vestiduras, para as repartirem entre si. Estas vestiduras, segundo o uso comum com que se vestiam os hebreus, eram uma túnica comprida até os pés, e com mangas, e 
sobre esta um manto quadrado, com que se cobriam, como nós com a capa. $(\mathrm{O}, 1657)$

b) no século XVIII:

(21) Vi as cartas de Vossa Mercê em que me avisa do estado em que se acham as madeiras, sua condução, e sobre as mais dependências dessa feitoria, estimei muito que Vossa Mercê visse tudo, e as notícias que me dá quanto às duvidas que se lhe põem aos telheiros, só em uma parte tem razão, que é em dizer também se devem fazer nos outros portos aonde vêem para as madeiras, no que não em dizer que se hão de conservar melhor sem eles, porque a experiência nos tem mostrado, que todos quantos se tem feito, sem esta prevenção se tem corrompido, e perdido as madeiras, e sua despesa, pelo que o Mestre se lembre do que me disse tocante à cidade Pernambuco, e esquece-se de que muitas vezes me falou na necessidade de telheiro, e em tudo. Determinava fazer junto às casas do homem que mora naquele porto e em que se achavam os paus, pegado ao dela: carpinteiro parece bom homem. (CO, 1723)

c) no século XIX:

(22) [...] assumi a suprema direção dos negócios públicos e, do que tenho feito, na órbita administrativa, vos informarão minuciosa e circunstanciadamente os relatórios. (O, 1895)

d) no século XX:

(23) Esta Comissão Parlamentar de Inquérito tem realizado uma tarefa realmente meritória e já convocou, para prestar depoimentos, algumas das figuras mais importantes da área fiscal. (O, 1974)

Observemos agora as ocorrências do PPS em diferentes séculos e a suas relações com grau de formalidade: 
Tabela 9 - O PPS e o grau de formalidade dos textos nos séculos XVI ao XX

\begin{tabular}{|c|c|c|c|c|c|c|}
\hline & \multicolumn{6}{|c|}{ PPS } \\
\hline & \multicolumn{2}{|c|}{ [+] Formal } & \multicolumn{2}{|c|}{ [-] Formal } & \multicolumn{2}{|c|}{ TOTAL } \\
\hline & № & $\rightarrow \%$ & № & $\rightarrow \%$ & № & $\rightarrow \%$ \\
\hline XV & 268 & $45 \%$ & 327 & $\mathbf{5 5} \%$ & 595 & $100 \%$ \\
\hline XVII & 334 & $48 \%$ & 357 & $52 \%$ & 691 & $100 \%$ \\
\hline XVIII & 206 & $45 \%$ & 253 & $55 \%$ & 459 & $100 \%$ \\
\hline XIX & 228 & $41 \%$ & 326 & $59 \%$ & 554 & $100 \%$ \\
\hline XX & 145 & $27 \%$ & 396 & $73 \%$ & 543 & $100 \%$ \\
\hline
\end{tabular}

A tabela acima nos mostra que o PPS predomina em textos informais dos séculos XIX (59\%) e XX (73\%). Acreditamos que isso ocorra devido os tipos de textos que compunham esse grupo: eram cartas que, em sua maioria, continham narrações de fatos que ocorriam com o escritor.

Já nos séculos XVI, XVII e XVIII quase não houve diferença do número de ocorrências da forma simples nos textos formais e informais (aproximadamente 50\% em cada tipo de texto), pois os textos que compunham o nosso corpus correspondente a essas épocas, tanto [-] formal como [+] formal, possuíam trechos em quee o escritor ora narrava fatos acontecidos no Brasil ou com ele, ora comentava a situação socioeconômica do Brasil. Portanto, podemos concluir que o grau de formalidade parece não influenciar na rentabilidade do PPS.

Assim os resultados das Tabelas 8 e 9 revelam que, com exceção da forma composta no século XVI, o que pode condicionar o emprego das duas formas pretéritas analisadas é a situação textual (contextos que favoreçam os usos das formas pretéritas de acordo com a intenção comunicativa do falante), e não o grau de formalidade do texto.

\section{Considerações finais}

Ao analisarmos e compararmos as ocorrências do Pretérito Perfeito Simples (PPS) e do Pretérito Perfeito Composto (PPS) no 
Português Brasileiro (PB) confirmamos a nossa hipótese de que essas formas verbais se distinguem pelos seus valores aspectuais e não pelos valores temporais. Sob esse ponto de vista temos a seguinte caracterização semântica para cada uma das formas pretéritas estudadas:

(a) no Pretérito Perfeito Simples todos os estágios se realizam dentro do intervalo de tempo $\left(I_{t}\right)$ compreendido pelo evento;

(b) no Pretérito Perfeito Composto, mais de um estágio ou evento completo está necessariamente incluído no $I_{t}$ podendo a interação do auxiliar com a base resultar em duas interpretações baseadas em seus valores aspectuais: iteração e duração.

Essa proposta de caracterização do PPC ajuda-nos a entender por que os eventos (ou estágios) expressos por essa forma verbal podem ser interpretados como se estendendo até o presente ou futuro: o fato de certos eventos/estágios se localizarem no intervalo de tempo em questão abre a possibilidade para que outros eventos/ estágios venham a se realizar fora desse $I_{t}$.

Sendo assim, o PPC pode, além de marcar tempo pretérito, constituir-se em operador de aspecto quantificacional, que produz como resultado eventos plurais relacionáveis à continuidade (duração) ou descontinuidade (iteração). O Pretérito Perfeito Simples (PPS) também pode expressar a pluralização de eventos, mas não de maneira explícita como a forma composta, precisa estar combinado com um adjunto adverbial.

O estudo diacrônico apresentado nos mostrou que essa distinção aspectual entre o PPS e o PPC encontrada (e perceptível) no português atual se consolidou apenas no século XX, pois no período compreendido entre os séculos XVI ao XIX podemos encontrar ocorrências de PPC com valor semelhante ao de outras línguas românicas, como o francês, e ao nosso PPS: exclusivamente perfectivo. 
Esse resultado permitiu-nos concluir que os valores que atualmente atribuímos ao PPC já podiam ser encontrados no século $\mathrm{XVI}$, embora com menos vitalidade. Isso implica que essa característica já existia no Português Europeu (PE) e chegou até nós com a vinda dos colonizadores e dos jesuítas.

O estudo histórico do PPC revelou-nos, também, que, a partir do século XVII, a percentagem de ocorrências dessa forma, com valor exclusivamente perfectivo, vai diminuindo, chegando ao século XIX com apenas 5\% e caindo em desuso no século XX.

Quanto aos resultados do Pretérito Perfeito Simples (PPS), observamos que essa forma sempre exprimiu o valor exclusivamente perfectivo. Entretanto, como já salientamos, a seu modo, combinado com adjunto adverbial, também pode ser utilizado para expressar iteração e/ou duração:

(24) Ele sempre gostou muito de Maria.

Por meio deste estudo diacrônico, tentamos refazer o percurso, desde a sua origem, das duas formas do Pretérito Perfeito do modo indicativo no Português Brasileiro (PB). Acreditamos que o "passado é por definição, um dado que coisa alguma pode modificar", mas o conhecimento do passado pode ser constantemente descoberto, transformado.

\section{Referências bilbiográficas}

BARBOSA, J, B. Tenho feito/fiz a tese: uma proposta de caracterização do Pretérito Perfeito no português. Araraquara, 2008. 282fls. Tese (Doutorado em Linguística e Língua Portuguesa) - Faculdade de Ciências e Letras, Universidade Estadual Paulista, Araraquara, 2008.

BARBOSA, J. B. Os tempos do pretérito no português brasileiro: perfeito simples e perfeito composto. Araraquara, 2003. Dissertação (Mestrado) - Unesp, Araraquara, 2003.

BOLÉO, M. de P. O pretérito e o perfeito em português, em confronto com as outras línguas românicas. Coimbra: Imprensa da Universidade, 1936. 
CASTILHO, A. T. A sintaxe do verbo e os tempos do passado em português. Alfa, 9, Marilia, FFCL, 1966, p.105-53. . Introdução ao estudo do aspecto verbal na língua portuguesa. Marília: Faculdade de Filosofia, Ciências e Letras, 1968.

COMRIE, B. Aspect. Cambridge: Cambridge University Press, 1976.

CORÔA, M. L. M. S. O tempo nos verbos do português: uma introdução a sua interpretação semântica. Brasília: Thesaurus, 1985.

COSERIU, E. Sincronia, diacronia e história. Rio de Janeiro: Universidade de São Paulo, 1979.

ILARI, R. Notas para uma semântica do passado composto em português. Revista Letras, Curitiba, n. 55, p. 129-52, jan./jun. 2001.

LABOV, W. Sociolinguistic Patterns. Philadelphia : University of Pennsylvania Press, 1972.

. Principles of linguistic change: internal factores. Oxford: Blackwell, 1994.

PAIVA, M. C.; DUARTE, M. E. A. Mudanças linguísticas: observações no tempo real. In: MOLLICA, M. L. \& BRAGA, M. C. (orgs.). Introdução à sociolinguística: o tratamento da variação. São Paulo: Contexto, 2003. p.179-90.

REICHENBACH, H. Elements of symbolic logic. Nova Iorque: Dover, 1980 [1947].

SILVA, R. V. M.. Ensaios para uma sócio-história do português brasileiro. São Paulo: Parábola Editorial, 2004.

VIANA, A. R. G. Le portugais: phonétique et phonologie, morphologie, textes. Leipzig: Teubner, 1901.

WEINREICH, U.; LABOV, W.; HERZOG, M. I. Empirical foundations for a theory of language change. In: LEHMANN, W. P.; MALKIEL, Y. (eds.). Directions for historical linguistics: a symposium. Austin: University of Texas Press, 1968. p.95-199. 


\section{4 \\ O ESTUDO DA TEMPORALIDADE VERBAL NA LÍNGUA ESPANHOLA: CONTRIBUIÇÕES À DIALETOLOGIA ARGENTINA ${ }^{1}$}

Leandro Silveira de Araujo ${ }^{2}$

\section{A elaboração de um corpus dialetal do espanhol argentino}

A fim de proceder ao estudo, entre outros, da temporalidade verbal na língua espanhola nas sete regiões dialetais da Argentina (Fontanella De Weinberg, 2004), elaboramos um corpus composto por materiais linguísticos que registram "a linguagem natural realmente utilizada por falantes e escritores da língua em situações reais" (Berber Sardinha, 2000, p. 352).

Se nos dedicamos a uma rápida busca de corpora em língua espanhola de acesso disponível na internet, encontraremos materiais que aparentemente poderiam nos servir para consulta e como resposta a muitos objetivos que eventualmente possa surgir. No entanto, nenhum deles nos oferece as informações extralinguísticas que julgamos imprescindíveis para uma proposta de estudo que busque uma aproximação dialetal dos fenômenos linguísti-

1 O presente capítulo resulta de parte das discussões realizadas em minha disseração de mestrado (Araujo, 2012a), defendida no programa de Pós-Graduação em Linguística e Língua Portuguesa, da Faculdade de Ciências e Letras da Universidade Estadual Paulista Júlio de Mesquista Filho - Unesp/Araraquara.

2 Professor da Universidade Federal de Uberlândia. 
cos analisados (Araujo, 2012b). Assim, atentando-nos à descrição do entorno enunciativo e dos enunciadores, considerando nossas limitações espaciais e temporais e atentos à definição de corpus tida por Sanchez (1995), na qual se busca um conjunto de "dados linguísticos", "sistematizados segundo determinados critérios", "extensos", "representativos da totalidade do uso linguístico ou de algum de seus âmbitos" e passíveis de processamento computacional, acreditamos haver encontrado, em entrevistas radiofônicas, condição satisfatória para a composição de um corpus da variedade argentina da língua espanhola.

Isso porque, além da possibilidade de obtermos esses enunciados e as informações extralinguísticas por meio da internet - em rádios das sete regiões dialetais que de transmissão on-line -, sabemos que eles pertencem a um gênero textual que resgata uma variedade linguística próxima ao vernáculo (Marcuschi, 2008). Conscientes de que enunciados pertencentes a um só gênero, de uma única modalidade da língua (falada), não podem constituir um corpus representativo da totalidade de usos de uma comunidade de fala, reconhecemos que as análises linguísticas provenientes deste corpus estão limitadas a um importante âmbito do uso do castelhano na Argentina, no qual se observa o domínio da oralidade, com pouco monitoramento e espontâneo.

Seguindo a tipologia proposta pela Linguística de Corpus (Berber Sardinha, 2000, p.339-42), esse conjunto de enunciados se identifica com o modo falado, pois tanto em sua concepção como em sua propagação faz uso da oralidade. Enquanto ao tempo, trata-se de um corpus sincrônico e contemporâneo, por abordar um único período: o corrente. É dialetal e especializado, por apresentar um conteúdo que visa satisfazer uma análise dialetológica e por decorrer de um único domínio discursivo: o jornalístico. Além disso, é um corpus de língua nativa, já que seus autores também são nativos.

A escolha dos municípios representantes das variedades estudadas privilegiou a importância sócio-político-econômica que possuem em relação aos demais da mesma região. Partindo do pressuposto de que, por serem referências no âmbito social, essas cidades atuam muitas vezes como modelo linguístico, selecionamos os 
seguintes municípios representantes de cada uma das sete regiões dialetais propostas por Fontanella de Weinberg (2004): Buenos Aires (Região Bonaerense), Rosário (Litoral), Posadas (Nordeste), San Miguel de Tucumán (Noroeste), Córdoba (Central), Mendoza (Região Cuyana) e Comodoro Rivadavia (Patagônia).

Finalmente, observamos que foram transcritas $5 \mathrm{~h} 37 \mathrm{~min} 15 \mathrm{seg}$, referentes à gravação de 33 entrevistas radiofônicas. O que nos forneceu mais de 57 mil palavras, sendo, em média, mais de oito mil a quantidade de palavras provenientes de cada região. Em relação ao objeto de análise deste estudo, o pretérito perfecto compuesto, foram encontradas 309 ocorrências. O Quadro 1 detalha as informações do corpus.

Quadro 1 - Da descrição das entrevistas radiofônicas que compõem o corpus

\begin{tabular}{|c|c|c|c|c|c|c|c|c|c|c|}
\hline Regiöo & Rádio & Site & Progmama & $\begin{array}{c}\mathrm{N}^{\circ} \\
\text { Entrew. }\end{array}$ & $\begin{array}{c}\text { Tempo de } \\
\text { grovogoo } \\
\text { totol } \\
\end{array}$ & $\begin{array}{c}\mathrm{N}^{\circ} \mathrm{de} \\
\text { polovros }\end{array}$ & $\begin{array}{c}\mathrm{N}^{\circ} \mathrm{de} \\
\mathrm{PPC}\end{array}$ & $\begin{array}{l}\mathrm{N}^{\circ} \mathrm{de} \\
\text { Inform. }\end{array}$ & $\begin{array}{l}\text { Idade } \\
\text { (onos) }\end{array}$ & $\begin{array}{l}\text { Sexo } \\
\text { Femin. }\end{array}$ \\
\hline \multirow{2}{*}{$\begin{array}{l}\text { 1. Bcnosrense } \\
\text { (Euenos Aires) }\end{array}$} & Conthentol & vow contingntal_com or & La maîno & \multirow[b]{2}{*}{4} & \multirow[b]{2}{*}{$00: 466^{\circ} 58^{\prime \prime}$} & \multirow[b]{2}{*}{7.770} & \multirow[b]{2}{*}{20} & \multirow[b]{2}{*}{6} & \multirow[b]{2}{*}{$37-70$} & \multirow[b]{2}{*}{2} \\
\hline & Polermo & www.radicpalermo.com.or & \begin{tabular}{|c|} 
Comunos en Plural \\
Entre nosstras
\end{tabular} & & & & & & & \\
\hline $\begin{array}{l}\text { 2. Cuyna } \\
\text { (Mendozo) }\end{array}$ & LV10 & www. Ivdiezcom or & \begin{tabular}{|c|} 
La deportiw \\
Tiempos Modermos
\end{tabular} & 6 & $00: 47^{\prime 1} 14^{\prime \prime}$ & 8.104 & 45 & 13 & $33-51$ & 4 \\
\hline \multirow[b]{2}{*}{$\begin{array}{c}\text { 3. Nonosste } \\
\text { (5.M. de Tucumán) }\end{array}$} & LV 12 (Indep.) & wUW.1012.com or & \begin{tabular}{|l|l|} 
Wharyinges en ha radio \\
\end{tabular} & \multirow[b]{2}{*}{5} & \multirow[b]{2}{*}{$00: 47^{\prime} 56^{\prime \prime}$} & \multirow[b]{2}{*}{8.467} & \multirow[b]{2}{*}{76} & \multirow[b]{2}{*}{8} & \multirow[b]{2}{*}{$37-59$} & \multirow[b]{2}{*}{2} \\
\hline & LV7 & wwew. 167 som sor & \begin{tabular}{|c|} 
La moñna dz LV7 \\
Tarde \\
\end{tabular} & & & & & & & \\
\hline $\begin{array}{l}\text { 4. Centrol } \\
\text { (Córdobo) }\end{array}$ & Coden 3 & wwu coden $03.00 \mathrm{~m}$ & \begin{tabular}{|c|} 
Corrusel \\
Sucesos deport ivos \\
Meda ds cofÉ \\
\end{tabular} & 5 & 00:50'56" & 9.088 & 86 & ll & $21-67$ & 0 \\
\hline \multirow[b]{2}{*}{$\begin{array}{c}\text { 5. Nordeste } \\
\text { (Posodos e outros) }\end{array}$} & $\begin{array}{l}\text { Anteno Lho } \\
\text { Reporbliog }\end{array}$ & 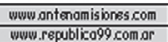 & \begin{tabular}{|c|} 
Dijo la mdio \\
Estomos En vuelto
\end{tabular} & \multirow[b]{2}{*}{5} & \multirow[b]{2}{*}{$00: 48^{\prime} 40^{\prime \prime}$} & \multirow[b]{2}{*}{7.995} & \multirow[b]{2}{*}{29} & & & \\
\hline & Misiones & wew notcissdel $6.00 \mathrm{~m}$ & \begin{tabular}{|c|} 
La maînono \\
Jorge Kurrle \\
$X X X$ \\
\end{tabular} & & & & & 18 & $31-66$ & 3 \\
\hline & Meridiom & wuw.fmmeridiom.com.or & Zonade noticios & & & & & & & \\
\hline (Rosorio'/W. Juano) & Morí Jum & WWw.radiomorigjuam.com & Comunizóndonos & 4 & $00: 48^{\prime} 32^{\prime \prime}$ & 8.441 & 30 & 7 & $24-60$ & 1 \\
\hline & La deportive & www.lodeportivo.oom.ar & Puntapis nicial & & & & & & & \\
\hline & Visión & wew.fmrodiovision.com & Lo moñ̄mo dz hay & & & & & & & \\
\hline (Com. Rivadavin) & Plus 10 & wew plus $10.00 \mathrm{~m}$ or & $\begin{array}{l}\text { Cafe comodoro } \\
\text { La revisto }\end{array}$ & 4 & $00: 46^{\prime} 34^{\prime \prime}$ & 7.204 & 23 & 9 & $37-55$ & 0 \\
\hline TOTRL & 14 ródios & & 22 progromos & 33 & $05: 37^{\circ} 15^{\prime \prime}$ & 57.069 & 309 & 67 & $21-70$ & 12 \\
\hline
\end{tabular}

Em suma, apesar de aparentemente pequeno, o corpus composto para a observação da língua espanhola nas sete regiões dialetais da Argentina propicia a análise do uso de alguns fenômenos linguísticos, como é o caso do pretérito perfecto compuesto, podendo apontar, dessa forma, semelhanças e diferenças nas regiões dialetais do país. A importância de considerarmos características extralinguísticas na composição do corpus pode nos auxiliar, ainda, com um estudo mais apurado. A coleta de enunciados pertencentes a entrevistas radiofônicas propicia-nos um material com um uso linguístico mais espontâneo, por sua concepção e divulgação orais, e mais próximo a um uso menos monitorado, como nos aponta Marcuschi (2008). 


\section{A variação linguística no uso do pretérito perfecto compuesto espanhol: ponderações sobre o estado da arte}

Apesar da existência de uma bibliografia significativa que sistematize o uso do pretérito perfecto compuesto (PPC - "este año se han tirado trescientos millones de litros de agroquímicos en esta sola campaña"), verificamos uma tendência à descrição de uso da forma verbal tal como ocorre em variedades peninsulares (Araujo, 2009). Quando mais atentas à língua espanhola falada na América, essas descrições tornam-se ainda mais breves e tendem a generalizar o valor do pretérito a todas as variedades linguísticas, como se seu uso fosse o mesmo ou estivesse muito próximo. Essa é a postura assumida por Moreno de Alba (2000) e Cartagena (1999) - para citarmos apenas dois autores.

Voltando-nos especificamente ao caso da Argentina, verificamos que as análises do perfecto compuesto seguem duas tendências. A primeira, de generalização, pode ser verificada nas seguintes asseverações:

[...] a pesar de que la segunda forma [PPC] tienda a desaparecer en beneficio de la primera [PPS], especialmente en hablantes de algunas regiones hispanoamericanas, como en Argentina. (Lamiquiz Ibañez, 1969, p.261, grifos nossos)

[...] na Argentina há maior disparidade entre o uso das duas formas verbais. Neste pais, a forma he visto corresponde a 4,7\% das 235 ocorrências do pretérito perfecto, e vi corresponde a 95, 3\%. (Oliveira, 2007, p.63, grifos nossos).

Como se observa, as informações apresentadas sobre o PPC são assumidas como comuns a todo o território argentino. Não obstante, faz-se necessário destacar que ao menos Oliveira (2007) fundamenta sua conclusão a partir da observação da variedade bonaerense, somente.

A segunda postura, de dicotomização, é defendida, entre outros, por Gutiérrez Araus (2001) e Jara (2009). Nessa perspectiva, res- 
tringe-se fundamentalmente o uso da forma composta a dois blocos opositivos: o da variedade encontrada em Buenos Aires e o de uma variedade "mais ao norte do país", passando-nos a impressão de que o uso dessa forma verbal demonstra somente dois comportamentos. Salientamos que tanto a postura de generalização como a de dicotomização inserem-se em um contexto de escassez de pesquisas dedicadas efetivamente à descrição dos valores atribuídos ao PPC - haja vista que grande parte delas restringe-se a informações impressionistas e pouco esclarecedoras.

Diante da ausência de uma descrição um pouco mais aprofundada do uso efetivo do PPC na Argentina, nosso trabalho justifica-se por intentar avaliar com quais valores o emprego da forma composta dá-se nas diferentes regiões dialetais do país; esclarecendo, assim, as aparentes variações no uso do perfecto compuesto e verificando até que ponto podem-se generalizar diatopicamente esses valores no país em questão.

Finalmente, devemos nos ater à tendência quase que generalizada à análise do uso do pretérito perfecto compuesto a partir da comparação com o pretérito perfecto simple (Yo, ayer, cuando me enteré de la noticia, me agarró un escalofrío) - tratando, dessa maneira, as duas formas verbais como variantes de uma variável. Em outras palavras, ao assumir tal postura, parece se pressupor que o PPC e o PPS compartilham exatamente o mesmo valor linguístico. Pressuposto que consideramos questionável porque, do mesmo modo como afirma Álvarez Garriga (2009):

[...] cada forma aporta un significado diferente a la comunicación y [...] la elección por una u otra forma, lejos de ser libre o azarosa, es motivada por la intención comunicativa del hablante en su búsqueda por trasmitir un mensaje coherente, según ciertos fines, en un contexto determinado [...] (ÁLVAREZ GARRIGA, 2009, p.2)

Acreditamos que, conforme o dialeto observado, ao PPC podem-se associar diferentes valores que nem sempre são expressos pelo PPS - assim como que a este também podem se associar valores não expressos por aquele. Desse modo, cremos que uma análise que 
verifique a variação de usos entre o PPS e o PPC - tratando-os como formas variantes - só deve ocorrer quando se tenha claro em que contexto(s) ambas as formas apresentam um mesmo valor semântico. Mais uma vez, justifica-se a importância deste trabalho, haja vista que assentará as bases para uma futura comparação entre ambas as formas, bem como para a avaliação das comparações já existentes.

Uma vez que nosso trabalho parte do respeito à complexidade linguística que possui o espanhol, nossa contribuição estará também preocupada com a condução do leitor à observação da língua em sua situação real de uso e, a partir dessa manifestação em interação com seu entorno sociodiscursivo, à compreensão de como o falante vale-se do pretérito perfecto compuesto para expressar uma realidade específica. Assim, graças à análise da prática linguística, conseguiremos inferir e entender os valores associados ao PPC e como seu uso é determinado pelo entorno linguístico e extralinguístico.

\section{Os valores atribuídos ao pretérito perfecto compuesto nas regiões dialetais da argentina}

A fim de iniciarmos a análise do uso do pretérito perfecto compuesto nas regiões dialetais da Argentina, observemos o quadro seguinte. Nele, procuramos expor, fundamentalmente, a quantidade de casos do PPC encontrada no corpus e sua relação com os valores atribuídos à forma verbal. Assim, as sete primeiras colunas formadas por dados numéricos destinam-se à descrição mais atenta do PPC nas sete regiões dialetais argentinas. Por sua vez, a última coluna totaliza os casos encontrados no país. ${ }^{3}$ Chamamos atenção aos dados por indicarem o valor mais recorrente (tanto em cada uma das regiões como no país, de modo geral) e os segundo e terceiro valores mais verificados no corpus.

3 O símbolo "\#” faz menção à quantidade de casos de PPC encontrados com cada sentido nos respectivos subcorpora e "\%" faz referência ao peso proporcional que guarda cada sentido em relação à quantidade total de ocorrências em cada região. 
Quadro 2 - Da distribuição das ocorrências do PPC conforme seus valores e regiões

\begin{tabular}{|c|c|c|c|c|c|c|c|c|c|c|c|c|c|c|c|c|c|}
\hline \multirow{2}{*}{ Valores Região } & \multicolumn{2}{|c|}{ Bonaerense } & \multicolumn{2}{|c|}{ Patagônica } & \multicolumn{2}{|c|}{ Nordeste } & \multicolumn{2}{|c|}{ Litoral } & \multicolumn{2}{|c|}{ Cuyana } & \multicolumn{2}{|c|}{ Noroeste } & \multicolumn{2}{|c|}{ Central } & \multicolumn{2}{|c|}{ Total } & \multirow{2}{*}{ ü } \\
\hline & $\#$ & $\%$ & \# & $\%$ & \# & $\%$ & $\#$ & $\%$ & \# & $\%$ & \# & $\%$ & \# & $\%$ & \# & $\%$ & \\
\hline Antepresente & 0 & 0,0 & 0 & 0,0 & 7 & 24,1 & 0 & 0,0 & 2 & 4,4 & 7 & 9.2 & 7 & 8,1 & 23 & 7,4 & \\
\hline Passado Imediato & 0 & 0,0 & 5 & 21,7 & 2 & 6,9 & 0 & 0,0 & 1 & 2,2 & 12 & 15,8 & 1 & 1,2 & 21 & 6,8 & \\
\hline Resultado & 11 & 55,0 & 8 & 34,8 & 13 & 44,8 & 14 & 46,7 & 29 & 64,4 & 14 & 18,4 & 40 & 46,5 & 129 & 41,7 & ? \\
\hline Experiencial & 5 & 25,0 & 3 & 13,0 & 2 & 6,9 & 6 & 20,0 & 9 & 20,0 & 13 & 17,1 & 22 & 25,6 & 60 & 19,4 & \\
\hline Persistência & 1 & 5,0 & 2 & 8,7 & 4 & 13,8 & 5 & 16.7 & 3 & 6,7 & 9 & 11,8 & 11 & 12,8 & 35 & 11,3 & 岁 \\
\hline Passado absoluto & 3 & 15,0 & 4 & 17.4 & 1 & 3,4 & 5 & 16,7 & 0 & 0,0 & 19 & 25,0 & 4 & 4,7 & 36 & 11,7 & $\vec{\gtrless}$ \\
\hline Antepretérito & 0 & 0,0 & 1 & 4,3 & 0 & 0,0 & 0 & 0,0 & 1 & 2,2 & 2 & 2,6 & 1 & 1,2 & 5 & 1,6 & \\
\hline Prospectivo & 0 & 0,0 & 0 & 0,0 & 0 & 0,0 & 0 & 0,0 & 0 & 0,0 & 0 & 0,0 & 0 & 0,0 & 0 & 0,0 & \\
\hline total & 20 & 100,0 & 23 & 100,0 & 29 & 100,0 & 30 & 100,0 & 45 & 100,0 & 76 & 100,0 & 86 & 100,0 & 309 & 100,0 & \\
\hline
\end{tabular}


Aproximando-se dos dados expostos sob uma perspectiva quantitativa, chama-nos a atenção a preponderante ocorrência do valor de resultado nas regiões dialetais do país - com exceção à região noroeste, onde ocupa a segunda posição entre os valores mais recorrentes. Em consequência, este é também o valor mais recorrente na análise geral do corpus compilado. Aliado a esse cenário global, destacam-se os valores experiencial, de passado absoluto e de persistência. Aquele, com 19,4\% dos casos totais, mostra-se como o segundo valor mais recorrente no corpus e estes dois últimos ocupam a terceira posição por representarem, cada um, pouco mais de $11 \%$ das ocorrências totais.

É relevante destacar que esse panorama de valores mais recorrentes do PPC pode variar conforme nos dirigimos mais pontualmente a algumas das regiões argentinas. Tanto é assim que as regiões $p a-$ tagônica e nordeste inserem, respectivamente, os valores de passado imediato $(21,7 \%)$ e antepresente $(24,1 \%)$ na segunda posição dos valores mais recorrentes dentro dos subcorpora analisados. Aproveitando o ensejo, especificamente sobre esses dois sentidos, é válido observamos que os subcorpora das regiões patagônica, bonaerense e do litoral não apresentam qualquer caso do PPC com valor de antepresente, assim como o valor de passado imediato não figura nessas duas últimas regiões citadas. Não deixemos de observar que, apesar desses valores figurarem nas regiões cuyana, noroeste e central, há, nelas, outros usos que ocorrem com frequência proporcionalmente maior.

Margeando outras particularidades na distribuição dos valores mais usuais nas regiões, observemos que tanto em Buenos Aires (bonaerense) como em San Miguel de Tucumán (noroeste) figuram mais recorrentemente os sentidos de resultado, experiencial e passado absoluto, diferenciando-se, no entanto, pela ordem em que aparecem, isso porque, em Buenos Aires, o valor de resultado figura em primeiro lugar, sendo seguido pelo valor experiencial e pelo valor de passado absoluto. Em San Miguel de Tucumán, por sua vez, o valor de passado absoluto assume a posição de maior produtividade, passando o sentido de resultado e experiencial para a segunda e terceira posições, respectivamente. 
A região central e a região cuyana diferenciam-se das duas regiões anteriores por apresentarem o valor de persistência na terceira posição, sendo este antecedido pelos valores de resultado (primeiro) e experiencial (segundo). De maneira muito semelhante, na região do litoral a ocorrência dos valores segue a mesma ordem dos dados apresentados anteriormente, no entanto, nota-se o valor de passado absoluto ocorrendo na mesma proporção que o valor de persistência - ambos na terceira posição. Sobre o valor prospectivo, nenhum caso foi encontrado em todo o corpus que compilamos.

Atendo-nos à quantidade total de ocorrências do PPC por área, conferimos que as regiões Noroeste e Central apresentam a maior quantidade de uso do PPC, sendo, respectivamente, $76(24,6 \%)$ e $86(27,8 \%)$ casos verificados em cada um dos subcorpora. Assim, juntas, as duas zonas são responsáveis por mais de 50\% dos casos verificados no corpus (52,4\%). Por sua vez, as regiões Bonaerense (20/ 6,5\%), Patagônica (23/ 7,4\%), Nordeste (29/9,4\%) e do Litoral (30/9,7\%) apresentam um uso mais tímido do PPC, o qual não alcança os $10 \%$ - em cada uma delas - do total geral no corpus. Desse modo, somadas as quatro regiões, encontramos 33\% dos casos totais do PPC encontrados no corpus compilado para nossos propósitos de análise. Finalmente, parece que a região metropolitana de Mendoza - região cuyana - possui uma recorrência intermediária do PPC, isso porque notamos 45 casos, que correspondem a pouco menos de $15 \%$ do total.

Tendo em vista os dados apresentados, passemos para uma abordagem qualitativa, a fim de melhor abalizar a definição dos valores atribuídos ao pretérito perfecto compuesto nas sete regiões dialetais Argentinas.

\section{Antepresente}

O primeiro valor tomado do Quadro 2 é o de antepresente, e como previamente comentado, foi encontrado nos subcorpora das cidades de Posadas (Nordeste), da região metropolitana de Mendoza 
(Cuyo), de San Miguel de Tucumán (Noroeste) e de Córdoba (Central). De modo geral, observam-se $23(7,4 \%)$ casos do PPC com esse valor. A seguir, expomos alguns enunciados retirados do corpus que exemplificam o valor em discussão:

(01) <NORDESTE> [ en este año] hemos tenido eh... mucha eh suerte en esta eh instancia de la me... mediatización de muchos problemas, incluso el de hambre cero [...]. (POS, 26, Gr 02) (02) <CUYO> Se está, en este momento, capacitando a toda la estructura censal. Ya se ha capacitado a los jefes de departamento, a los jefes de fracción y hora sigue, en la próxima etapa, la capacitación a jefes de radio. (MDZ, 32, Gr 05)

(03) <NOROESTE> Lo que hemos hecho en este primer tramo de nuestra gestión es sentar las bases de trabajo. (TUC, 45, Gr 03) (04) <CENTRAL > [...] este año se han tirado trescientos millones de litros de agroquímicos en esta sola campaña. (COR, 17, Gr 02)

Sabe-se que o valor de antepresente relaciona-se mais intimamente com o traço do tempus, ${ }^{5}$ uma vez que se constitui na relação do momento do evento (ME) com o momento de fala (MF). Para sermos mais claros, a partir da Figura 1, podemos conferir que, nesse valor, tanto o $\mathrm{ME}$ como o MF são envoltos por um mesmo âmbito primário, o qual recebe o nome de momento de referência presente (MR-Presente) por possibilitar a visualização de uma ação pretérita a partir de uma perspectiva de presente.

4 Entender como <PROVÍNCIA; NÚMERO DA GRAVAÇÃO; NÚMERO DA OCORRÊNCIA NO CORPUS $>$. No campo referente à PROVÍNCIA, podem figurar POS (Posadas), MDZ (Mendoza), TUC (San Miguel de Tucumán), COR (Córdoba), CMR (Comodoro Rivadivia), BSAS (Buenos Aires)e ROS (Rosario), siglas das cidades de onde originaram os dados que alimentaram o corpus de análise.

5 Como categoría dêtica, o tempus constrói-se e se organiza a partir da enunciação. Desse modo, as referências temporais dos eventos descritos dão-se sempre tendo em vista o momento de enunciação. 
Figura 1 - Dos valores de antepresente e passado imediato

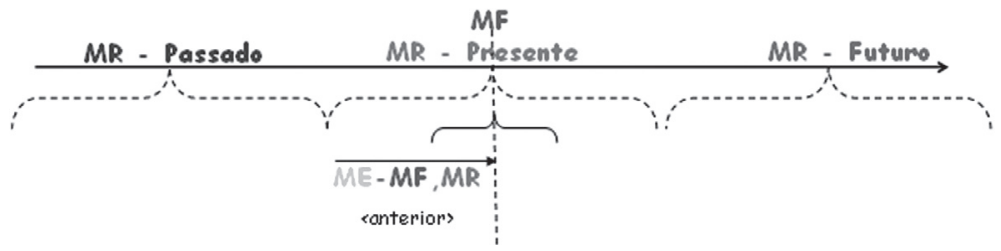

A presença de marcadores temporais que expressam um tempo suficientemente amplo para envolver tanto o evento (ME) como o ato de fala $(\mathrm{MF})$ pode evidenciar esse valor. Tanto é assim que a observação dos dados oferecidos pelo corpus mostrou-nos que a maior parte dos enunciados portadores desse valor possui um marcador temporal explícito que salienta o valor de antepresente. Conscientes dessa característica e atentando-nos, a título de exemplo, ao fragmento da região cuyana, observamos que enquanto o advérbio "ya" enfatiza o término da ação descrita, o marcador temporal "en este momento" assinala-nos justamente que, apesar de pretérito, o evento (ME) é envolto pelo mesmo momento de referência que abarca o MF.

A importância de um marcador temporal para esse uso parece ser tamanha que, na ausência de um deles, o contexto discursivo possibilita-nos a sua fácil inferência. Tanto é assim que recuperamos facilmente a locução adverbial elíptica en este año no enunciado (01) (nordeste). ${ }^{6}$ Ainda descrevendo os marcadores que circundam o PPG quando portador deste valor, a Real Academia Espanhola (RAE) (2009) explica-nos ser muito comum a construção de locuções adverbiais temporais a partir do pronome demonstrativo este. De fato, com exceção a "en el último año", todos os outros marcadores temporais encontrados junto ao uso do PPC com o valor de antepresente trouxeram o demonstrativo explícito em sua estrutura composicional. Vejamos os casos encontrados no corpus:

6 A melhor inferência desse marcador temporal dá-se mais facilmente se consideramos um contexto discursivo maior, no qual observamos outras referências à concepção temporal expressa pelo marcador elíptico. 
"esta semana", "en este momento"(02), "en este año y medio", "en este primer tramo de nuestra gestión” (03), "este año" (04).

A partir da observação do modo de açãa $o^{7}$ vigente nos enunciados encontrados, podemos concluir que esse tipo de informação parece não ser determinante na atribuição do valor de antepresente à forma verbal, haja vista que encontramos os quatro tipos de modo de ação descritos por Vendler (1967) associando-se ao PPC quando detentor desse sentido: estado ("tener mucha suerte" (01)), atividade, achievement ("capacitar a los jefes" (02)) e accomplishment ("hacer eso" (03)).

\section{Passado imediato}

De comportamento muito semelhante ao sentido anteriormente estudado, o valor de passado imediato também compartilha a aparente sobrepujança do traço de tempus na determinação de seu valor. No entanto, específico a ele seria o fato do âmbito primário de perspectiva presente (MR) - que envolve o momento do evento (ME) e o momento de fala (MF) - ter uma abrangência menor, alcançando, no máximo, a envoltura temporal de um dia (Alarcos Llorach, 2005). Logo, a distância temporal entre o evento e o ato de fala é encurtada a, no máximo, 24 horas.

Conforme nos acusam os dados expostos no Quadro 2, o valor de passado imediato é o terceiro valor menos recorrente na totalidade do corpus de análise (23 casos, 6,8\%) e figura em apenas cinco dos sete subcorpora observados: Patagônia, Nordeste, Cuyo, Noroeste e Central. Observemos os enunciados exemplificadores do valor:

(05) <PATAGONIA> [... ] venís a decir lo tuyo. Seguramente, después de todo lo que has escuchado en este comienzo del programa. (CMR, 01, Gr 01)

7 Por modo de ação entendemos os recursos léxico-semânticos que contribuem para a informação relativa à aspectualidade, sendo esse valor oriundo do significado léxico do verbo junto a outros elementos que o acompanham, tais como os argumentos do verbo, advérbios e locuções adverbiais, entre outros. 
(06) < NORDESTE > Tienen que ver la foto, tienen tienen que ver la la foto... le he sacado [hace poco] un par de fotos que seguramente después eh van a salir replicadas en triple doble ve antena misiones punto con. (POS, 08, Gr 01)

(07) $<\mathrm{CUYO}>[\ldots]$ algo que ha sorprendido en las últimas horas tiene que ver con la...eh... el crecimiento de algunos proyectos que vienen desde China directamente. (MDZ, 27, Gr 05)

(08) <NOROESTE > [...] mirá la sonrisa que me echa paz cuando ha dicho [recién] "a elección". (TUC, 14, Gr 02)

(09) <CENTRAL > Diez y media de la noche estaba todo cerrado, salvo una pizzería que se llama La Romana y un lugar que... adonde hemos almorzado hoy que se llama Ocean Baquer, que es de pescado. (MDZ, 03, Gr 01)

Observando os marcadores temporais que podem salientar o valor de passado imediato, encontramos no corpus de análise as seguintes expressões: "en este comienzo de programa" (05), "en las últimas horas" (07), "hoy” (09), "recién”, "ahora”. Outra característica importante observada no corpus deve-se a que esses marcadores temporais são preponderantemente explícitos em enunciados portadores desse sentido. Não obstante, quando ausentes, facilmente detectamos os marcadores temporais implícitos que identificam a aproximação existente entre o ME e o MF - esse foi o procedimento adotado nos enunciados (06) (nordeste) e (08) (noroeste), nos quais inferimos, respectivamente, hace poco e recién. Evidentemente, o processo de inferência desse marcador temporal dá-se a partir de um contexto discursivo maior; de modo que se observamos o fragmento (08), por exemplo, verificaremos um outro integrante do contexto de enunciação lendo uma mensagem de celular segundos antes de se enunciar o trecho presente.

Além do traço do tempus e da presença do marcador discursivo enfatizando o tipo de relação temporal existente entre o ME e o $\mathrm{MR}$, uma terceira característica foi possível ser identificada a partir da observação do corpus. Conforme os dados observados, parece 
haver uma maior preponderância de enunciados em achievement ("algo que ha sorprendido" (07)) e accomplishment ("le he sacado un par de fotos” (06)), modos de ação que se caracterizam por apresentar ações terminativas, ou seja, com ponto final inerente. Por consequência, essa informação parece também reforçar a ideia de completude do evento descrito.

\section{Resultado}

O próximo valor contemplado pelo Quadro 2 é o de resultado, o qual, devido a seu alto índice de ocorrência (129 casos, 41,7\%), pode ser verificado facilmente em todos os subcorpora analisados. A característica básica desse valor é apresentar, no momento de enunciação, a relevância de uma eventualidade já concluída. Em outras palavras, esse uso da forma composta promove a apreciação de estados atuais e resultantes de uma situação pretérita. A fim de melhor observarmos estas e outras características, atentemo-nos ao uso do PPC em alguns exemplos retirados do corpus de análise:

(10) < BONAERENSE $>$ [...] yo prácticamente me he criado este... en en en el teatro avenida, este... luego dirigí espectáculo de café con sed y de niños, pero nunca me atreví a un texto así...tan importante. (BsAs, 16, Gr 04)

(11) < PATAGONIA > No, cada cual hizo su propuesta [...], pero... los tres tenían... coinciden en algo fundamental que era el objetivo. [... ] se ha empezado a transitar que es que Bussi sea el próximo gobernador [...]. (CMR, 14, Gr 03)

(12) < NORDESTE > [...] la motoniveladora eh tratando de de de trabajar la tierra seguramente para que la mancha de petróleo no siga avanzando sobre las costas, en este caso ya ha llegado a las costas de Florida ¿no? (POS, 02, Gr 01)

(13) <LITORAL> [...] se hizo con tanta rapidez éxito y con tanta rapidez fracaso que creo que les hemos sacado valor y significado a las palabras [...]. (ROS, 19, Gr 04) 
(14) $<\mathrm{CUYO}>[\ldots$... el muy mal comienzo de tigre y la irregularidad demostrada por Gimnasia y River de la Plata le han permitido al equipo de Ángel Capa [...] quedar al gordo de salir de la promoción [...]. (MDZ, 01, Gr 01)

(15) <NOROESTE> [...] me gustaría que nos confirme usted: ¿ [ya] ha presentado finalmente la renuncia a la obra social del PAMI filial Tucumán? (TUC, 53, Gr 05)

(16) <CENTRAL> Las fuertes multas y la fuerte clausura se... han estado cuarenta y cinco días, negocios clausurados, por el expendio de alcohol [...]. (MDZ, 63, Gr 05)

Tal como nos mostram os enunciados elucidadores, o uso do PPC permite que a relação entre uma situação inicial e uma situação final dê-se de três formas:

1) Com o PPC expressando o resultado final de uma situação anterior já terminada. Esse é o caso do fragmento da região litorânea (13), no qual entendemos que "les hemos sacado valor y significado a las palabras" resulta da forma rápida como se fez "éxito" e "fracaso". Da mesma maneira, podemos encontrar essa relação causal nos fragmentos das regiões patagônica (11), cuyana (14) e central (16).

2) Com o PPC expressando a causa de um resultado expresso na continuação do enunciado. Verificamos essa situação no fragmento retirado no subcorpus da região bonaerense (10), no qual o fato de ter se criado no teatro permitiu ao enunciador dirigir diferentes espetáculos. ${ }^{8}$

3) Com o PPC expressando a causa de um resultado não expresso na continuação do enunciado, mas implícito na realidade discursiva instaurada. Esse é o caso, por exemplo,

8 Apesar de não veicular propriamente o resultado de um estado ou ação anteriores, nesse contexto de uso, o PPC ainda se relaciona com o valor de resultado por apresentar uma cena inicial terminada que demonstrará as consequências resultantes de seu término - na continuação do enunciado - por ser ainda relevante para o enunciador. 
do fragmento oriundo da região noroeste (15), em que ao fazer uso do PPC para perguntar se o secretário de governo já "ha presentado finalmente la renuncia", o enunciador deixa implícita a possibilidade de haver, na atualidade, alguma mudança na gerência do Pami.

O traço aspectual perfeito, ${ }^{9}$ presente no PPC, é o principal agente constituidor desse sentido, pois é essa informação aspectual a responsável por marcar no presente a relevância de uma ação passada (Comrie, 1993; García Fernández, 1995; 2008; Cartagena, 1999). $\mathrm{O}$ valor pode ser observado na figura seguinte, na qual a lente e as linhas pontilhadas representam o tempo de foco, isto é, o momento posterior ao término do evento (representada por $x$ ) e quando se vislumbram as consequências provenientes dele. Notemos também que o $T F$ envolve o momento de fala (MF), fazendo que as consequências observadas sejam concomitantes à enunciação.

Figura 2 - Do valor resultativo

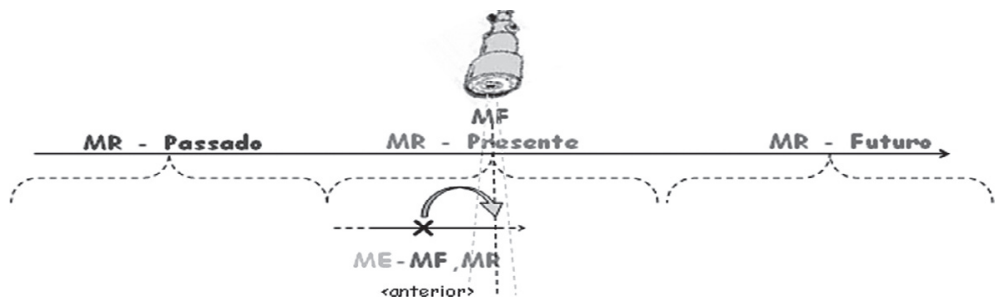

Ainda de acordo com nossa análise do corpus, notamos a preponderância de predicados em achievement e accomplishment na expressão desse valor. Acreditamos que isso se deve a que os dois modos de ação apresentam acontecimentos cujo limite é inerente; e

9 Nessa classe aspectual, o foco (TF) volta-se ao momento que está imediatamente posterior ao tempo da situação (TS), mostrando-nos, por isso, os resultados de TS ou, em outras palavras, a relevância presente de uma situação concluída. É consciente desse valor que Comrie (1993) afirma que o perfeito não nos diz nada diretamente sobre a situação em si, mas relata alguns estados de uma situação precedente. 
que, por isso, possibilitam a expressão (ou impressão da existência) de um estado resultante da situação antes descrita. Essa característica vai diretamente ao encontro das palavras de Rodriguez Louro (2008), quem já afirmara a maior recorrência desse valor junto a enunciados télicos.

Em particular, o modo de ação achievement - significativamente mais recorrente que o accomplishment - recebe um especial destaque junto ao valor de resultado, porque, por si só, implica a transição entre dois estados: um inicial e outro resultante deste. Esse é o caso, por exemplo, de permitir quedar al gordo, no fragmento da região cuyana, haja vista que se trata de uma oração que opõe uma situação inicial, em que não existe dada permissão, de uma situação final, na qual passa a vigorar a autorização. Não obstante, havemos de considerar que a observação do corpus indicou-nos também a existência de enunciados veiculadores de outros modos de ação, tanto é assim que o fragmento da região central apresenta um exemplo do modo de ação de estado (estar cuarenta y cinco dias).

Sobre a associação de marcadores temporais a enunciados portadores do valor resultativo, os dados acusam uma maior ocorrência de casos em que não figura nenhum marcador temporal explícito. No entanto, quando eventualmente se verifica a presença explícita de marcadores, observamos que eles não aportam um valor temporal especificador, mas, ao contrário, expressam um âmbito temporal suficientemente amplo para não determinar o momento quando se deu o evento, legando à situação descrita certo grau de inexatidão temporal. São estes os marcadores temporais associados aos enunciados portadores do valor de resultado que foram encontrados no corpus: "todo este momento", "siempre", "en los últimos tres partidos", "nunca", "en la vida", "en los últimos años”, "durante el mundial", "quince años", "algunas veces", "en esta carrera". Aliado a essas expressões temporais, devemos destacar a recorrente presença, explícita ou implicitamente, do advérbio “ $y a$ ”, o qual enfatiza que a eventualidade retratada já está concluída - observemos seu uso nos fragmentos retirados das regiões nordeste (12) e noroeste (15). 
Outro comportamento importante inferido a partir da observação do corpus está relacionado ao recorrente uso de estruturas que colaboram para a construção da relação lógica de causalidade existente entre uma situação inicial e uma situação final. Esse é o caso, por exemplo, de "luego", no enunciado oriundo do subcorpus da região bonaerense - conjunção que introduz o resultado de "haver se criado no teatro". São outros exemplos de expressões enfatizadoras de tal relação: "ya que", "y de esta manera", "así que", "porque", "entonces", "por eso", " a partir de eso", "por eso", "por lo tanto", " $y$ ", "por eso mismo, "sino".

\section{Experiencial}

Em quarto lugar no Quadro 2 figura o valor experiencial (sessenta casos, 19,4\%), sentido responsável por expressar eventos cujo momento de acontecimento e cuja iteratividade são indefinidos - dai decorre outro nome frequentemente associável ao uso. Apesar do desconhecimento dessas informações, sabemos que se trata de uma situação passada e já terminada. Observemos o uso do PPC com esse valor nos seguintes enunciados retirados do corpus:

(17) < BONAERENSE > Sí, bueno, mirá... este... en mi larga carrera de actor he dirigido espectáculos musicales, como los del Carmen Flores... (BsAs, 15, Gr 04)

(18) <PATAGONIA> Este... eh... pero hay básicamente Norma, mi señora, que es quien más me ha seguido en en cientas de aventuras, este... políticas [...]. (CMR, 05, Gr 03)

(19) $<$ NORDESTE $>$ [... ] las ventas en lo que es eh indumentaria oficial de la Argentina sube... Eh pelotas. Como que la gente manifiesta muchísimo las ansias por el mundial. En definitiva ¿qué es lo que más has vendido en este [copa]...? (POS, 04, Gr 01)

(20) $<$ LITORAL > Algunas veces los socios han presentado reclamos [...] (ROS, 16, Gr 04)

(21) <CUYO> O [algunas veces] lo hemos contemplado viendo cada vez que alguien ha asistido de que los ingresos a los lugares 
bailables, eh... digamos no haya gente que que ingrese con una arma blanca o arma de fuego. (MDZ, 16 e 17, Gr 04)

(22) <NOROESTE $>$ [...] veintitrés presidentes, exactamente. Hemos conducido la casa los cincuenta y siete años de vida. Eh... ah... muchos de los cuales han dedicado grandes esfuerzos [...]. (TUC, 36, Gr 03)

(23) <CENTRAL> [...] vamos a hablar ya mismo, precisamente, con Jorge Valenti que ha hecho esa y otras declaraciones para esta nota de la voz del interior. (COR, 07, Gr 02)

Os fragmentos anteriores mostram-nos, mais uma vez, que há ocorrência do valor experiencial associado ao uso do PPC em todas as regiões dialetais argentinas. Em relação à construção do sentido que promulga, os enunciados das regiões patagônica (18), litorânea (20) e cuyana (21) mostram-nos que a ausência de um delimitador temporal abre precedentes para uma interpretação muito ampla do âmbito temporal em que dado evento aconteceu. Assim, a situação descrita pode haver sucedido em qualquer momento durante um extenso momento, que pode envolver até mesmo toda a vida do enunciador ou de quem se está falando. De fato, a observação do corpus mostrou-nos que os enunciados portadores desse valor são preponderantemente constituídos sem a presença dessa estrutura temporal especificadora. Assim, a título de exemplo, a observação do enunciado (21) indica-nos que a "contemplação" pode ter ocorrido diversas vezes em uma abrangência temporal suficientemente extensa para envolver toda a vida política do enunciador.

Por outro lado, é possível observar também o uso de alguns marcadores temporais que especificam um pouco mais o momento em que o(s) evento(s) sucedeu(ram) - esse é o caso dos fragmentos das regiões bonaerense (17. "en mi larga carrera”), nordeste (19. "en este [copa]"), noroeste (22. "los cincuenta y siete años de vida”) e central (23. "esta nota de la voz del interior”). Entretanto, mesmo usando o marcador temporal, não se sabe exatamente quando e nem com que frequência se deram os eventos descritos. 
Ainda observando as estruturas periféricas ao PPC que operam na construção do valor experiencial, chamamos a atenção aos elementos que podem auxiliar no aporte do traço de iteratividade. Dentre eles, destacamos:

Complemento verbal plural: Como no fragmento das regiões bonaerense (17. "[...] he dirigido espectáculos musicales”), litorânea (20. "han presentado reclamos"), noroeste (22. "han dedicado grandes esfuerzos") e central (23. "[...] ha hecho esas y otras declaraciones").

Sujeito plural: Como nos fragmentos das regiões litorânea (20), cuyana (21) e noroeste (22), nas quais figuram, respectivamente, "los socios", "nosotros" - oculto - e "muchos de los cuales".

Locuções de valor iterativo: Expressões como "varias veces", "muchas veces", "algunas veces" - esta é a que observamos, por exemplo, nos fragmentos (20) e (21).

Outras estruturas adjuntas ao verbo: Como no fragmento extraído do subcorpus da região patagônica (18), no qual se lê "[... me ha seguido en cientas de aventuras".

Como se visualiza nos enunciados exemplificadores, o favorecimento do traço de iteratividade não depende da ocorrência simultânea de todas as estruturas elencadas acima, mas basta haver uma única delas aliada ao traço de indefinição temporal. Em comum, observa-se também que todos esses indicadores trazem a marcação de pluralidade.

Finalmente, a observação do uso do PPC com esse valor no corpus possibilitou-nos comprovar que, do mesmo modo como já havia descrito Rodriguez Louro (2008), o sujeito das orações de valor experiencial possui o traço animado, tanto é assim que encontramos nos fragmentos acima expostos os seguintes sujeitos oracionais: "yo", "Norma, mi señora,", "tú”, "los socios”, "nosostros", "alguién", "muchos [presidentes]", "Jorge Valentî"10 Essa característica implica reconhecermos que as situações descritas pelos enunciados foram experimentadas por um alguém e que, por isso,

10 Todos os pronomes pessoais sujeito estão elípticos. 
podemos parafrasear o uso do PPC nesse contexto por "ha tenido la experiência de" + infinitivo (sendo o infinitivo a forma do verbo anteriormente conjugado em PPC) (ibidem).

Aplicando esse procedimento aos fragmentos expostos, observamos, por exemplo, que o enunciado (17) poderia ser lido como:

(24) < BONAERENSE > Sí, bueno, mirá... este... en mi larga carrera de actor he tenido la experiencia de dirigir espectáculos musicales, como los del Carmen Flores... (BsAs, 15, Gr 04)

Por fim, sobre o modo de ação presente nas orações, a análise dos casos encontrados mostrou-nos que o uso do PPC com esse valor pode estar associado a qualquer um dos quatro tipos apresentados por Vendler (1967). O valor experiencial pode ser contemplado na seguinte figura, na qual, as letras $(x)$ tracejadas mostram-nos o desconhecimento da quantidade de vezes que ocorre o evento descrito. Por sua vez, a linha temporal tracejada acusa-nos a indefinição do momento exato em que se deu a situação. Podemos observar, contudo, que apesar de tamanha imprecisão, parece que a situação continua sendo tratada dentro do âmbito primário de coexistência (MR-Presente), de modo que o falante pode estendê-lo a ponto de envolver toda a sua vida:

Figura 3 - Do valor experiencial

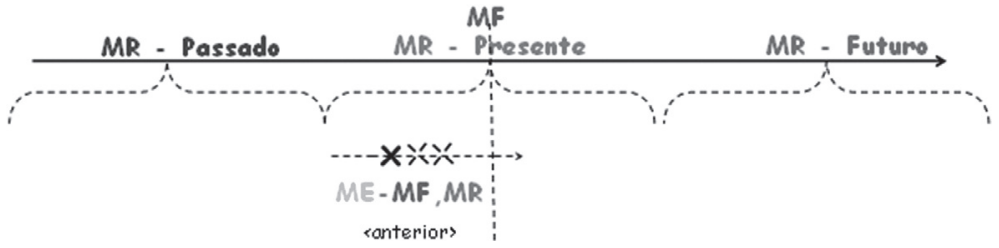

\section{Persistência}

Outro valor que também figura entre os usos mais frequentes é o de persistência - quinto sentido exposto no Quadro 2, com 35 
casos (11,3\%). Como também observamos nos enunciados abaixo, trata-se de um uso verificado nos subcorpora de todas as regiões dialetais da Argentina.

(25) < BONAERENSE > [...] te cuento, Analía, yo era muy inquiero de chico o sea que... que con los años también me he añejado y sigo siendo inquieto [...]. (BsAs, 20, Gr 04)

(26) <PATAGONIA> No. La verdad, que el peronismo [siempre] me ha tratado de maravilla. No no nunca... nunca tenía planteado nada [...]. (CMR, 05, Gr 03)

(27) < NORDESTE $>[\ldots]$ entre toda esta situación que hemos vivido [en estos últimos días] - la la la desaparición física de Néstor Kirchner, eh no tiene que hacer este... he reflexionado sobre lo que significa la palabra compromiso ¿no? (POS, 17, Gr 04)

(28) $<$ LITORAL $>$ Eh... Antes que nada, bueno... eh de alguna manera transmitirte... este.... qué se yo, esta sensación que tenemos todos los hinchas, por lo bien que ha actuado Cultura Canalla, que le ha puesto un poco de sentido común a todo este momento [...] (ROS, 01, Gr 01)

(29) <CUYO> En este marco, eh... se ha estado capacitando [hasta ahora] aquellas personas que van a ser instructores, entonces, el cierre de esta capacitación consistía en esta práctica para que ellos pudieran aplicar el cuestionario. (MDZ, 33, Gr 05)

(30) < NOROESTE > [...] confederación general económica en la República Argentina una entidad que... durante muchos años ha sido, sin dudar, la líder en el gremialismo empresario nacional. (TUC, 34, Gr 03)

(31) <CENTRAL > [...] cada uno de ellos tiene libertad de construir su candidatura eh... en el medio se van a ir buscando las alianzas que tradicionalmente ha tenido el peronismo con otros partidos, partidos provinciales $u$ otras fuerzas políticas. (COR, 45, Gr 04)

O valor de persistência é responsável por expressar eventos cujo início dá-se antes do momento de fala, mas que duram (persistem) até - ou após - a enunciação. Assim, na figura seguinte temos 
as letras $(x)$ expressando a reiteração da situação até o ato de fala $(\mathrm{MF})$. O uso do $(x)$ tracejado mostra-nos a possível continuidade da situação após MF.

Figura 4 - Do valor de persistência

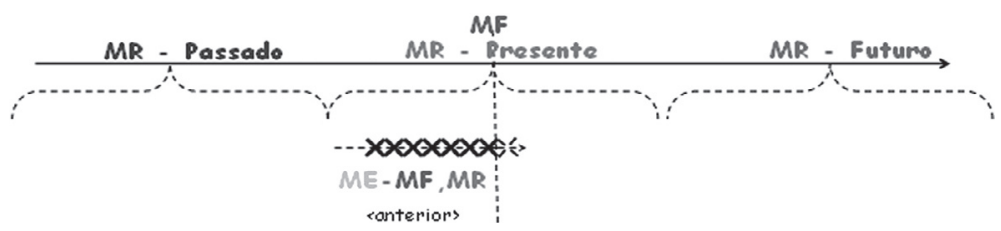

Observando os traços que contribuem para a construção desse sentido, cremos que é relevante considerar a sobrepujante presença de orações em modo de ação estativo ou de atividade. Isso porque ambos os modos de ação expressam situações cujo término não está marcado; possibilitando, portanto, a impressão da manutenção de dado evento.

Essa característica pode ser observada em grande parte dos fragmentos expostos acima. Dentre eles, destacamos, a título de exemplo, os enunciados da região nordeste (27) e do litoral (28), nos quais figuram, respectivamente, os verbos vivir - de modo de ação estativo - e actuar - de modo de ação de atividade. Haja vista que apresentam situações imutáveis que podem continuar ocorrendo indefinitivamente (Vendler, 1967; Riemer, 2010), ao dizer "hemos vivido [en los estos últimos días] la desaparición física de Néstor Kirchner", tem-se, desde um momento passado, um estado decorrente da morte do mandatário que persiste ininterruptamente até o presente. De modo muito semelhante, ao dizer "[...] lo bien que ha actuado Cultura Canalla", permite-se inferir que a "atuação" do grupo de torcedores também se estende desde o passado até o presente.

Por outro lado, não podem passar despercebidas outras estruturas linguísticas que também operam na construção do sentido de persistência, esse é o caso da informação de tempus, a qual nos permite ver, a partir de uma perspectiva de presente, uma situa- 
ção cujo início se dá no passado. A informação do aspecto perfeito é também relevante, pois procura relacionar, de algum modo, o evento iniciado no passado com o momento de enunciação. Dessa maneira, toda a cena durativa criada resulta da integração desses e outros elementos que verificaremos a seguir.

Antes, porém, ressaltamos que, apesar da expressiva ocorrência dos modos de ação citados, semelhante a Rodriguez Louro (2008), não negamos a possibilidade de verificarmos tipos de modos de ação cujo término do evento descrito é inerente - achievement e accomplishment. Esse é o caso, por exemplo, do enunciado da região patagônica, em que "tratarme" é uma ação que possui um término previsto. No entanto, ao associá-lo ao marcador temporal siempre - que aporta um valor reiterativo e de duração - propicia-se a interpretação de persistência. Assim sendo, parece-nos importante ater-nos também a alguns marcadores temporais que corroboram o sentido em pauta.

Desse modo, observamos no corpus o uso dos seguintes marcadores: "con los años" (25), "en los últimos días" (27), "a todo este momento" (28), "hasta ahora" (29), "desde entonces", "durante muchos años" (30), "tradicionalmente" (31), "los cincuenta y siete años [que estamos completando hoy]", "[toda la vida]", "en los últimos venticinco años", "siempre”, "por tantos años", "en los últimos años”, "a través de los años", "[desde entonces]", "en estos tres años".

Por fim, a observação dos fragmentos (25) e (28) - da região bonaerense e litorânea, respectivamente - indica-nos que o uso de uma oração em tempus presente adjunta à oração cujo verbo está na forma do PPC pode servir também para salientar o sentido de persistência. Isso porque aproxima o evento iniciado no passado (PPC) da situação concomitante ao MF (Presente de Indicativo) e nos mostra que consequências essa ação em marcha causa no momento concomitante à enunciação. Assim, ao se dizer, no enunciado (28), que "esta es la sensación que tenemos los hinchas", mostra-se o cenário presente resultante do "bien que ha actuado" continuamente o grupo "Cultura Canalla". 
Para concluirmos, ressaltamos que a constituição do sentido de persistência dá-se pela união dos diferentes elementos linguísticos observados, não sendo necessário verificar a co-ocorrência de todos em um único enunciado.

\section{Passado absoluto}

O penúltimo valor contemplado pelo Quadro 2 é o de passado absoluto e, apesar de não ser considerado um uso canônico por diversos manuais de referência da língua espanhola, a observação de sua ocorrência no corpus indicou-nos que parece se tratar de um uso produtivo para a Argentina (36 casos, 11,7\%). Tanto é assim que figura em seis dos sete subcorpora e se insere entre os usos mais recorrentes em cinco das regiões.

Antes de nos atermos um pouco mais em como se constitui, observemos alguns enunciados retirados do corpus que elaboramos.

38. <BONAERENSE > [...] Mi labor específica y la labor de mi grupo es eh... llevar dignidad, por ejemplo, como lo hemos hecho el domingo pasado en el anfiteatro del parque Centenario. $<\mathrm{BsAs}, 05, \mathrm{Gr} 02>$. 39. $<$ PATAGONIA $>$ El concejal [...] quien nos ha brindado [ahora] eh... su perspectiva de acuerdo con lo que ha sido una sesión muy particular el último jueves. $<\mathrm{CMR}, 21, \mathrm{Gr} 04>$.

40. $<$ NORDESTE $>[\ldots]$ justamente terminamos ayer. Yo terminé [\#\#\#\#\#\#] hacer el homenaje a Néstor Kirchner. Eh... bueno, una eh... una sesión muy emotiva. [...] A la par, digamos, con las con las cámaras, en este caso, ha sido este homenaje ¿no? <POS, 15, Gr 04>. 41. <LITORAL> [...] bueno hace ya diez años, del dos mil [...] que estamos con este género, y bueno hay gente que ya del noventa y tres, noventa y cuatro ha estado cuando han hecho drácula acá [...] $<$ ROS, 10, Gr 03>.

42. <NOROESTE> [Yo creo] que ustedes mismo han sido el termómetro de lo que ha ocurrido con el cambio prestacional en aquel momento. $<$ TUC, 66, Gr 05>. 
43. $<$ CENTRAL $>$ Ayer ha habido algo diferente en la escena politica argentina. Diferente, digo, eh... porque se han reunido una sorprendente cantidad de dirigentes del partido justicialista. $<\mathrm{COR}$, 42, Gr 04>.

Observando, a principio, o traço do tempus, os enunciados mostram-nos que, quando portador desse valor, o PPC não expressa somente situações anteriores ao momento de fala, mas também vistas a partir de uma perspectiva de passado. Em outras palavras, a forma verbal deixa de ser um tempus relativo de anterioridade em relação a uma situação presente $((\mathbf{O o V})-\mathbf{V})$ - como quando portadora do valor de antepresente -, e passa a ser um tempus absoluto que expressa uma situação direta de anterioridade ao momento de fala $(\mathbf{O}-\mathbf{V})^{11}$, como verificamos na figura seguinte:

Figura 5 - Do valor de passado absolutosob a perspectiva de Guillermo Rojo

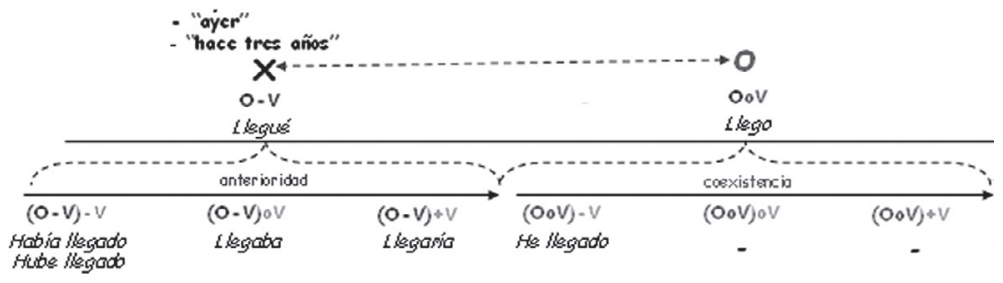

Quando detentora desse valor, a oração costuma apresentar algum marcador temporal que evidencia o sentido que descrevemos. Tanto é assim que nos fragmentos expostos encontramos "el domingo passado" (38. < bonaerense >), "el último jueves" (39.<patagônia $>$ ), "ayer" (40.<nordeste> e $43<$ central>, "del noventa y três, noventa y cuatro" (41. <litoral>) e "en aquel momento" (42. < noroeste>). Além desses marcadores, notamos os usos de "hace unos días atrás", "en su momento", "el sábado [pasado]", "hace aproximada-

11 Na notação de Rojo (1974, 1990, 1999) “(OoV)-V”correspondea uma situação relativa, isso é, anterior (-V) a um evento que é concomitante $(\mathbf{o V})$ ao ponto central (O). Por sua vez, "O-V" faz referência a um evento absoluto, pois traça uma relação de anterioridade (-V) diretamente em relação ao ponto central $(\mathbf{O})$. 
mente un año y medio", "unos días atrás", "un fin de semana largo [el pasado]", "en el curso de la semana de esa sesión [ya pasada]". Como vemos, todos os marcadores encontrados acusam uma separação temporal entre o momento do evento (ME) descrito e o momento de fala (MF); em outras palavras, o $\mathbf{M E}$ deixa de ser visto a partir de uma perspectiva (Referência) de concomitância ao $\mathbf{M F}$ e passa a ser observado a partir de uma perspectiva de anterioridade ao âmbito temporal que abarca a enunciação.

A observação do comportamento do modo de ação, do sujeito e dos complementos verbais - relevantes para a análise de alguns dos valores anteriores - mostrou-nos que, aparentemente, tratam-se de estruturas que não operam de forma determinante na construção do sentido de passado absoluto. Essa conclusão deveu-se ao fato desse valor associar-se aos diferentes tipos existentes em cada uma dessas categorias. Por outro lado, julgamos imprescindível nos atermos cautelosamente na contribuição aportada pelo aspecto perfeito ao sentido em questão. Isso porque, se compartilhamos da ideia de que há nessa forma verbal a manifestação deste traço aspectual (Comrie, 1993; García Fernández, 1995; 2008; Cartagena, 1999), passamos a visualizar as situações já terminadas como ainda relevantes no momento de fala.

Assim, poderíamos justificar o uso paralelo das formas simples ("terminamos", "terminé") e composta ("ha sido") do pretérito perfecto no fragmento retirado do subcorpus da região nordeste (40). Isso porque, enquanto na observação do traço do tempus verificamos uma aproximação semântica do PPC com o PPS, na observação do traço aspectual, verificamos uma diferenciação no sentido das formas. Isso se deve a que ao dizer "terminé" - forma do PPS que possui o valor de perfectivo ${ }^{12}$ - não há preocupação em marcar qualquer consequência que possa advir do fim da ação; no entanto, ao dizer "ha sido", descreve-se um estado já terminado, mas que, de alguma maneira, traça alguma relação com o momento de fala - mostrando-nos, por exemplo, a ainda atual presença do sentimento de luto.

$12 \mathrm{O}$ aspecto perfectivo, presente na forma do pretérito perfecto simple, retrata a fase final da situação apresentada sem se preocupar com o que vem após seu término. 
Por outro lado, se desconsideramos a informação aportada pelo traço aspectual do perfeito e, com isso, atemo-nos unicamente à informação dada pelo traço do tempus passado absoluto (ME,MR$\mathrm{MF} ; \mathrm{O}-\mathrm{V})$, podemos chegar a pensar que a forma composta (PPC) e a forma simples (PPS) encontram-se em variação nesse contexto de uso, haja vista que compartilhariam exatamente o mesmo valor e, portanto, comporiam uma variável linguística.

\section{Antepretérito}

Finalmente, o último valor vislumbrado pelo Quadro 2 é o de antepretérito. Conforme acusa-nos o corpus, trata-se de um uso bastante escasso (cinco casos, 1,6\%) e observável em somente quatro dos sete subcorpora totais. Vejamos, a seguir, alguns casos encontrados:

(44) < PATAGONIA > Evidentemente, la Justicia ya le hizo pagar, cumplió su condena, o sea que ya pagó lo que ha cometido y ahora, seguramente, lo va a juzgar en el día de mañana. (CMR, 02, Gr. 02). (45) <CUYO $>$ [...] este ensayo, en realidad, fue como la culminación de una instrucción que se les ha dado a las personas que van a ser instructores de los jefes de radio y de los censistas. (MDZ, 31, Gr 05) (46) <NOROESTE> Yo creo que en el fondo se sintieron molestos porque se han detectado algunas irregularidades o presuntas irregularidades en un área del PAMI que se llama relación con beneficiario [...]. (TUC, 68, Gr. 05).

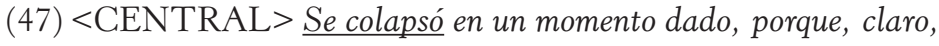
el personal de la telefónica no han previsto esta concentración tan grande y que todos los chicos hoy le damos un celular para comunicarlos. (COR, 83, Gr. 05).

Atentando-nos aos traços que compõem o valor de antepretérito, verificamos no tempus um comportamento que se assemelha ao do pretérito pluscuamperfecto de indicativo (pretérito mais que perfeito do indicativo), isso porque também expressa um evento (ME) 
anterior a uma situação/referência (MR) que, por sua vez, antecede o momento de fala (MF). Assim sendo, tomando a notação de Reichenbach (2004), representa-se esse tempus como ME-MR-MF e, na notação de Rojo (1999), como (O-V)-V.

Conforme observado nos quatro enunciados acima, os verbos conjugados no pretérito perfecto simple (ME, MR-MF) servem de referência passada para o PPC, haja vista que os eventos descritos pelo perfecto compuesto são anteriores aos expressos pela forma simples (ME-MR-MF). Dessa maneira, ao dizer "pagó", no enunciado (44), narra-se um evento que ocorre após a ação descrita pela forma composta, "ha cometido". Em outras palavras, a forma composta expressa uma anterioridade à forma simples.

Acrescentando o traço aspectual à análise desse valor, perceberemos que, semelhantemente ao que ocorre no uso do PPC com valor de passado absoluto, ao se utilizar o PPC no contexto semântico prototipicamente associado à forma do pluscuamperfecto de indicativo, marca-se, graças ao traço do aspecto perfeito, a relevância presente de um evento antepretérito. Assim, no fragmento (45), a ação antepretérita apresentada pelo PPC ("ha dado") implicaria não só a "culminação da instrução dos censistas", mas também a constituição, no MF, de um quadro de funcionários preparados para realizar o censo argentino. Em poucas palavras, conclui-se, mais uma vez, a importância de considerarmos o aspecto perfeito na análise do pretérito perfecto compuesto.

Esse parece ser também o caso de:

(48) [...] en una oficina que hemos montado [en aquel momento] en la calle córdoba que se llamó de Orientación de Prestaciones Médicas. (TUC; 64; Gr5).

No qual, entendemos a ação "se llamó" ('se chamou') como uma referência (MR) passada em relação ao momento da fala (MF), mas posterior ao evento "hemos montado" (ME). Aparentemente, o uso do pretérito perfecto compuesto nesse contexto visa, da mesma maneira que no lugar do passado absoluto, expressar a relevância presente de um evento passado, mas que desta vez é anterior ou an- 
tepretérito, como denomina Guillermo Rojo. Essa relevância presente, como já comentamos, só seria possível graças ao aspecto perfeito que vigora no PPC. Assim, no valor antepretérito, as consequências da eventualidade pretérita também são avaliadas a partir do momento de fala (MF), quando se fixa o tempo de foco (lente):

Figura 6 - Do valor de antepretérito com relevância presente

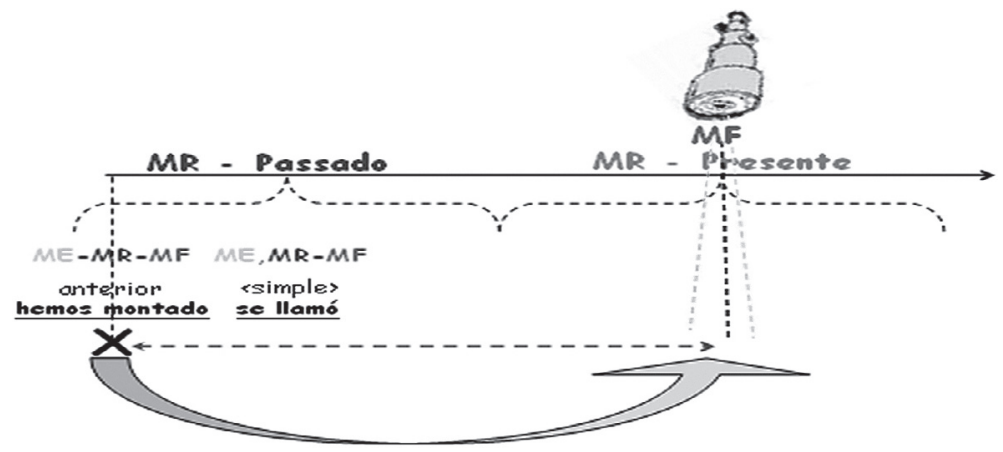

Em relação aos outros elementos que ocorrem conjuntamente ao uso do PPC portador desse valor, os dados mostram que o tipo de sujeito não parece ser uma informação determinante na constituição do valor. Sobre o modo de ação, no entanto, nota-se unicamente o uso de orações de término inerente, tanto em accomplishment (fragmento da região cuyana, por exemplo) como em achievement (fragmento da região patagônica). Não obstante, devido à escassa quantidade de casos do PPC com o valor de antepretérito, não podemos assegurar essa característica, do mesmo modo que não podemos afirmar muito sobre o uso de marcadores temporais junto a esse valor ${ }^{13}$.

\section{Contribuições à dialetologia argentina}

A fim de alcançarmos os objetivos finais do capítulo destinado ao estudo da temporalidade linguística do espanhol baseado em

13 Na prática, nenhum marcador foi encontrado nos enunciados veiculadores deste sentido. 
corpus, compete-nos ainda refletir sobre a contribuição deste trabalho para a dialetologia argentina. Para tanto, precisamos recuperar as informações descritas no início do tópico anterior, segundo as quais, verificamos, grosso modo, três comportamentos da forma composta sob o ponto de vista quantitativo:

(I) Mais de $52 \%$ das ocorrências dão-se nas regiões Noroeste e Central (76/ 24,6\% e 86/ 27,8\% casos, respectivamente);

(II) Juntas, as regiões Bonaerense (20/ 6,4\%), Patagônica (23/ 7,4\%), Nordeste (29/9,3\%) e do Litoral (30/9,7\%) apresentam somente $33 \%$ do total de casos encontrados. Em outros termos, o uso do PPC em cada região não alcança os $10 \%$ da totalidade dos dados encontrados no país.

(III) Os dados da zona metropolitana de Mendoza - região cuyana - correspondem a quase $15 \%$ do total de casos. Assim, pareceu-nos haver uma recorrência intermediária em relação à produtividade acusada pelos dois contextos anteriores.

Aliado ao comportamento quantitativo, uma análise qualitativa mostra-nos que esse três blocos também compartilham algumas características no que diz respeito à distribuição dos valores atribuídos ao PPC. Tanto é assim que verificamos:

(I) nas regiões central e noroeste a ocorrência de todos os valores observados alguma vez no país.

(II) nas regiões bonaerense, patagônica, nordeste e do litoral a ausência de pelo menos um dos sete valores observáveis em outras regiões. Em especial, nota-se uma maior afinidade entre as regiões bonaerense e litorânea, já que os subcorpora de ambas as áreas coincidem em não apresentar os valores de antepresente, passado imediato e antepretérito. Sobre os valores mais recorrentes, figura em todas as regiões o valor de resultado na primeira posição. Além disso, encontramos novamente um ponto de equivalência entre a zona bonaerense e litorânea, pois alocam o valor de passado absoluto na terceira posição entre os usos mais recorrentes. Há de se destacar também que a região patagônica aproxima-se do comportamento verificado nas regiões bonaerense e do litoral quando observamos os valores de antepresente e passado absoluto. 
(III) no subcorpora da região cuyana a ausência do valor de passado absoluto - verificado em todas as demais regiões. Por outro lado, o índice dos valores mais recorrentes segue a mesma tendência da ordem observada na totalidade do corpus de análise. Isso significa que se verificam os valores de resultado, experiência e persistência ocupando, respectivamente, o primeiro, o segundo e o terceiro lugares entre os casos mais recorrentes.

Antes de associarmos essas informações ao estudo da dialetologia argentina, precisamos considerar o conceito de isoglossa e sua relevância para a delimitação das regiões dialetais. Assim, sabe-se que isoglossa é uma linha imaginária que marca a abrangência territorial de um traço linguístico e de seu comportamento. Quando aliadas a outras isoglossas, formam um feixe e viabilizam uma delimitação dialetal fundamentada em aspectos linguísticos (Chambers; Trudgill, 1994; Cardoso, 2010). Desse modo, se assumirmos que o estudo que fizemos sobre o pretérito perfecto compuesto possibilitou-nos demarcar a isoglossa que nos explicita a abrangência espacial do comportamento do PPC, aceitaremos que, eventualmente, essa informação poderá contribuir para reforçar ou reavaliar as propostas de delimitação das regiões dialetais no país.

Com esse objetivo, a Figura 7 mostra-nos a extensão territorial dos três grupos que se mostraram detentores de uma norma semelhante de uso do PPC. A isoglossa superior mostra a abrangência territorial do comportamento I; a isoglossa que inicia na parte superior do mapa e que se estende até a região mais austral do país indica o comportamento II; e, finalmente, o comportamento III está representado pela isoglossa intermediária, que envolve uma estreita faixa territorial que faz divisa com o Chile. ${ }^{14}$

14 Não podemos desconsiderar que o perímetro das regiões que figuram no mapa 03 apresenta algum grau de generalização. Isso porque, ao nos orientarmos pela proposta de divisão dialetal feita por Fontanella de Weinberg (2004), pressupomos a existência de uma norma linguística relativamente comum empregada em cada uma das sete regiões dialetais postuladas, de modo que generalizamos os dados coletados em uma única cidade de cada região aos demais municípios envolvidos pelo perímetro total da zona. Não obstante, 
Figura 7 - Mapa da isoglossa do Pretérito Perfecto Compuesto na Argentina

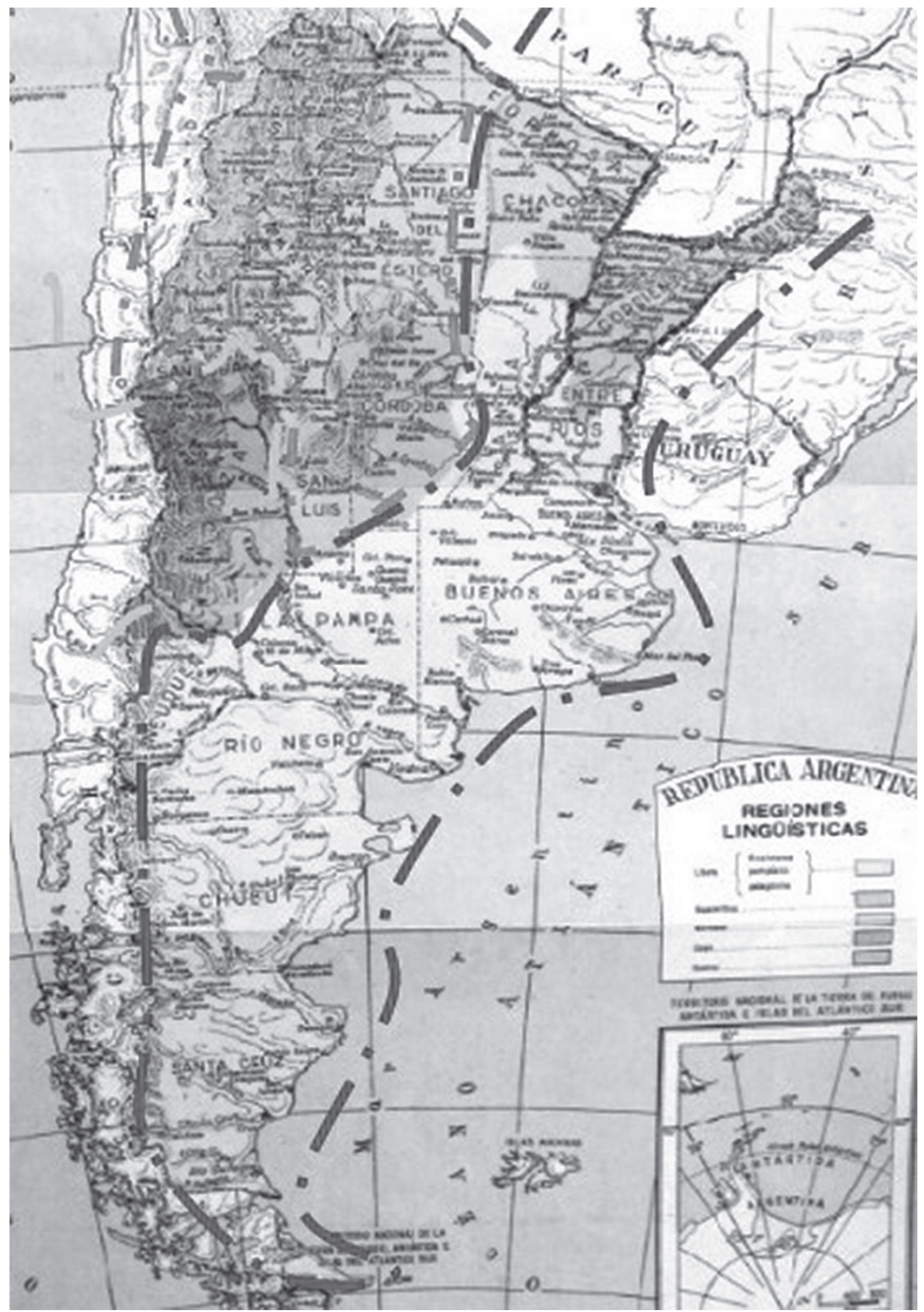

destacamos também que a escolha da cidade representante não foi aleatória, mas respeitou o principio da irradiação linguística (COSERIU, 1977), segundo o qual uma cidade de maior importância social, cultural, política, econômica e administrativa serve, muitas vezes, de modelo linguístico para as demais comunidades circundantes. 
Antes de prosseguirmos em nossas considerações, vale a pena reafirmarmos que não esperamos com esse rápido estudo propor uma nova divisão dialetal para o país - já que isso exigiria considerar um estudo que fornecesse um feixe de isoglossas. Nosso interesse consistiu somente em avaliar se o padrão de uso dialetal apontado pelo estudo do pretérito perfecto compuesto na Argentina corrobora alguma proposta vigente ou se, ao menos, assemelha-se a alguma delas. Quando muito, este estudo servirá também para o tracejado de uma isoglossa útil na eventual delimitação futura do país.

Seguindo na exploração do Figura 7, seus dados, curiosamente, possibilitam-nos dialogar também com os processos de colonização da Argentina. Segundo Vidal de Battini (1964) e Lipski (1994), "[...] la colonización de Argentina se llevó a cabo desde tres puntos distintos, cada uno de los cuales supuso diferentes formas de contacto y posterior evolución lingüística" (Lipski, 1994, p.184).

A primeira delas decorre de expedições vindas diretas da Espanha e que, em 1536, chegam à zona que mais tarde seria conhecida como Buenos Aires. Por razões de conflitos com nativos, esses primeiros colonizadores são expulsos e vão em direção ao Nordeste do país, fixando-se em Asunción (Paraguai). Anos mais tarde, regressam ao delta del plata e, em 1580, dá-se por fundada Buenos Aires. Nesse ir e vir, traça-se uma primeira rota entre o que hoje chamamos regiões Noroeste, Litorânea e Bonaerense. Se adiantarmos a história, contemplaremos, no século XVIII, uma suntuosa cidade próxima a se tornar sede do virreinato del Río de la Plata (1776) devido à nova rota criada entre Europa e o cone sul da América. Foi esse desenvolvimento econômico e administrativo local que motivou o envio - a partir de Buenos Aires - de expedições de colonização aos Pampas e à Patagônia argentina. Assim, anexa-se à zona de influência social e linguística de Buenos Aires a atualmente conhecida região patagônica.

A comparação entre a história do país e as informações da Figura 7 mostra-nos, portanto, uma possível justificativa para o comportamento $\mathrm{II}^{15}$ do pretérito perfecto compuesto, no qual verificamos

15 Isoglossa que inicia na parte superior do mapa e que se estende até a região mais austral do país. 
a macrorregião litorânea envolvendo quatro regiões ${ }^{16}$ sob forte interferência política, econômica, social e linguística de Buenos Aires. Em outras palavras, a observação do comportamento do PPC parece mostrar que, desde sua instituição, Buenos Aires vem servindo de referencial linguístico, senão para todo o país, como afirma Rojas (2001), ao menos para a macrorregião litorânea da Argentina.

Ainda segundo Vidal de Battini (1964) e Lipski (1994), uma segunda corrente migratória da Argentina teria sido constituída entre zonas de exploração do minério de prata (Peru e Bolívia) e áreas que possibilitassem a escoação do produto de maneira clandestina. Desse modo, os traficantes do minério deixavam as rotas oficiais e passavam a enviar o produto para um mercado paralelo via zona que mais tarde seria oficializada e conhecida como Buenos Aires. Como consequência, nota-se, nesse período, um crescimento demográfico das áreas mais ao noroeste do país e a fundação das primeiras cidades argentinas (Santiago del Estero, 1553; San Miguel de Tucumán, 1565; Córdoba, 1573; Salta, 1582; San Salvador de Jujuy, 1593). Conforme explica-nos Lipski (1994), a colonização dessa área foi realizada por pequenos camponeses e comerciantes espanhóis, o que contribuiu para a constituição de uma variedade do espanhol considerada, desde o início, rústica e menos elitizada. Soma-se às características desse processo migratório, a forte presença da cultura quéchua. Em confronto com os dados suscitados com a análise do pretérito perfecto compuesto na Argentina, verificamos, na Figura 7, que o comportamento I (isoglossa superior) coincide com esse processo de colonização. É pertinente observarmos que estudos sobre o PPC nas regiões andinas do Peru e da Bolívia (Howe; Schwenter, 2003; Kany, 1969; Gutiérrez Araus, 2001; Jara, 2009) indicam uma semelhança com o comportamento que encontramos para o PPC na macrorregião mediterrânea da Argentina, haja vista que também mostram uma maior recorrência da forma composta, inclusive com o valor de passado absoluto.

16 São as regiões Bonaerense, Litorânea, Noroeste e Patagônica as que compõem o comportamento II, da macrorregião litorânea. 
Finalmente, o terceiro processo de colonização no país origina-se no Chile e envolve a região de Cuyo. Fundadas em 1561 e 1562, Mendoza e San Juan, respectivamente, pertenceram ao país vizinho até que se instaurasse o virreinato del Río de la Plata, em 1776. Devido à aproximação da capital chilena, Lipski (1994) explica-nos que essa região vive ainda hoje sobre forte influência da variedade empregada em Santiago, sem deixar de sofrer, por outro lado, forte interferência de Buenos Aires, centro irradiador da norma mais prestigiada na Argentina. Como acusam os dados do Quadro 2 e da Figura 7, a atual região cuyana coincide com esse terceiro processo de colonização e apresenta um uso do PPC com algumas diferenças dos demais usos na Argentina; no entanto, como nos faltam informação precisas sobre o uso do PPC no Chile, não podemos afirmar qualquer aproximação com o país vizinho.

Antes de passarmos às considerações finais deste estudo, não podemos deixar de salientar que a associação que fazemos entre os comportamentos do PPC e o processo de colonização da Argentina não pretende, por hora, justificar o cenário do uso do PPC que encontramos no país. Mas, visamos apenas indicar uma aparente coincidência que, somente após comprovação sob uma análise diacrônica, poderia justificar, de fato, as razões para o atual uso da forma temporal que temos discutido. Finalmente, devemos ter muito claro que todas as informações aqui apresentadas são relativas à observação de um corpus constituído por entrevistas radiofônicas que envolveram falantes cuja origem e permanência está firmada em uma importante cidade de cada uma das sete regiões dialetais que consideramos no início desse trabalho. Por isso, qualquer afirmação que vá além desse âmbito metodológico, corre o risco de estar equivocada.

\section{Considerações finais}

A concretização deste trabalho possibilitou-nos conferir, a partir da análise do uso efetivo da língua espanhola na Argentina, que 
a forma composta do pretérito perfecto possui um comportamento polissêmico, tanto é assim que a observação de sua manifestação no corpus compilado mostrou-nos ser possível encontrar pelo menos sete valores associados a ela. A preocupação com o caráter dialetal que possuem os dados foi também outra marca que caracterizou nosso estudo, assim buscamos apoio na Dialetologia para descrevermos o comportamento do PPC tendo em vista sua distribuição no território Argentino.

A discussão sustentada mostrou-nos que, no país, há um uso relativamente heterogêneo da forma composta, isso é, dentre os oito valores aferidos na análise, sete foram verificados na Argentina, havendo uma recorrência de uso diferente conforme as regiões observadas. Em especial, seguindo a postura de Company Company (2002), Moreno de Alba (2000) e Jara (2009), verificamos na Argentina, de modo geral, o uso do perfecto compuesto com o traço aspectual de perfeito marcado.

Tendo em vista as contribuições da Dialetologia, verificamos que o estudo do PPC no país possibilitou-nos o tracejado de uma isoglossa que avalia a pertinência desses postulados, pelo menos, para a observação da forma composta. Isso é assim, porque os padrões de uso do PPC podem ser associados a três macrorregiões - nas quais se verifica um comportamento do PPC relativamente semelhante. Por sua vez, essas macrorregiões mostraram-nos, curiosamente, uma relação direta com o processo de colonização da Argentina - o qual ocorreu em três eixos: (1) Buenos Aires (região bonaerense) em contato com as regiões litorânea, noroeste e patagônica, (2) Regiões Nordeste e Central em interação com Peru e Bolívia e (3) a região de cuyo, sob forte interferência do Chile desde o início de sua colonização.

Com a conclusão dos estudos, conseguimos não só (1) descrever os valores atribuídos ao pretérito perfecto compuesto nas regiões dialetais argentinas, mas também (2) romper com as posturas de análise já existentes - segundo as quais haveria uma homogeneização ou uma dicotomização (Buenos Aires versus todo os demais) linguística no uso do PPC. Além de tudo isso, abrimos (3) precedentes para 
novas pesquisas sobre a forma verbal, fundamentalmente no que tangencia o (3a) tratamento do PPC e de seu comportamento no ensino de ELE; (3b) a análise contrastiva entre a forma do PPS e do PPC, tendo em vista seus valores particulares; (3c) como a evolução da forma no país justifica a situação atual de uso; (3d) como historicamente os diferentes processos de colonização da Argentina colaboraram para o estado atual do uso do PPC; entre outros.

\section{Referências bibliográficas}

ALARCOS LLORACH, E. Gramática de la lengua española. Madrid: Espasa, 2005.

ÁLVAREZ GARRIGA, D. Perfecto Simple y Perfecto Compuesto: Un análisis de su variación en los discursos de asunción a la Presidencia de Néstor Kirchner y Evo Morales. In: COLOQUIO ARGENTINO DE LA IADA: "DIÁlOGO Y DIÁlOGOS”, 4, 2009, La Plata. Coloquio Argentino de la IADA: "Diálogo y diálogos". La Plata: Universidad Nacional de la Plata, 2009.

ARAUJO, L. S. "La gramática lo propuso, pero he escuchado...": um estudo comparativo sobre o uso dos pretéritos indefinido e perfecto segundo a perspectiva da gramática normativa e a impressão de uso efetivo de hispanofalantes. Araraquara, 2009. $70 \mathrm{fls}$. Monografia de Conclusão de Curso (Bacharel em Letras) - Faculdade de Ciências e Letras, Universidade Estadual Paulista "Júlio de Mesquita Filho", Araraquara, 2009.

ARAUJO, L. S. Os valores atribuídos ao pretérito perfecto compuesto nas regiões dialetais argentinas. 2012. 212 f. Dissertação (Mestrado em Linguística e Língua Portuguesa) - Faculdade de Ciências e Letras da Universidade Estadual Paulista 'Júlio de Mesquita Filho', Araraquara, 2012a. Disponível em < http://portal.fclar.unesp.br/poslinpor/teses/Leandro_Silveira_Araujo.pdf>. Acessado em 13 de agosto de 2013.

ARAUJO, L.S. A elaboração de um corpus dialetal da língua espanhola falada na Argentina: contribuições dos gêneros discursivos e da análise textual automática. Estudos Linguísticos, São Paulo, v.1, p. 246-61, 2012b. Disponível em: < http://gel.org.br/estudoslinguisticos/volumes/41/el.2012_v1_t19.pdf>. Acessado em 11 jul. 2013. 
BERBER SARDINHA, A. P. Lingüística de corpus: histórico e problemática. D.E.L.T.A., São Paulo, v.16, p.323-67, 2000. Disponível em: http://www.scielo.br/pdf/delta/v16n2/ a05v16n2.pdf. Acesso em: 15 fev. 2011.

CARDOSO, S. A. Geolinguística: tradição e modernidade. São Paulo: Parábola, 2010.

CARTAGENA, N. Los tiempos compuestos. In: BOSQUE, I.; DEMONTE, V. Gramática descriptiva de la lengua española. Madrid: Espasa, 1999. 2 vols. p.2933-75.

CHAMBERS, J. K.; TRUDGILL, P. La dialectología. Madrid: Visor Libros, 1994

COMPANY COMPANY, C. Gramaticalización y dialectología comparada. Una Isoglosa sintáctico-semántica del español. Dicenda: Cuadernos de filología hispánica, Madrid, v.20, p.39-71, 2002. Disponível em: <http://dialnet.unirioja.es/servlet/listaarticulos? tipo_busqueda $=E J E M P L A R \&$ revista_busqueda $=417 \&$ clave_busqueda $=60535>$. Acesso em: 11 jul. 2011.

COSERIU, E. Geografía lingüística. In: COSERIU, E. El hombre y su lenguaje. Madrid: Gredos, 1977. p.103-58.

COMRIE, B. Aspect. Cambridge: Cambridge University Press, 1993.

FONTANELLA DE WEINBERG, M. B. (coord.). El Español de la Argentina y sus variedades regionales. 2. ed. Bahía Blanca: Asociación Bernardino Rivadavia, 2004.

GARCÍA FERNÁNDEZ, L. La interpretación temporal de los tiempos compuestos. Verba: Anuário Gallego de Filología, Santiago de Compostela, v.22, p.363-96, 1995.

. El aspecto gramatical en la conjugación. 2.ed. Madrid: Arco Libros, 2008.

GUTIÉRREZ ARAUS, M. L. Caracterización de las funciones del pretérito perfecto en el español de América. In: CONGRESO INTERNACIONAL DE LA LENGUA ESPAÑOLA, 2², 2001, Valladolid. Paneles y ponencias del II Congreso Internacional de la Lengua Española. Madrid: Centro Virtual Cervantes, 2001. Disponível em: <http:// congresosdelalengua.es/valladolid/ponencias/ unidad_diversidad_ del_espanol/2_el_espanol_de_america/gutierrez_m.htm $>$. Acesso em: 23 nov. 2008.

HOWE, C.; SCHWENTER, S. A. Present Perfect for Preterite across Spanish Dialects. Penn working papers in linguistics. Pennsylvania, v.9.2, p.61-75, 2003. 
JARA, M. El pretérito perfecto simple y el pretérito perfecto compuesto en las variedades del español peninsular y americano. Signo e Seña, Buenos Aires, n.20, p.255-81, 2009.

KANY, C. E. Sintaxis hispanoamericana. Madrid: Gredos, 1969.

LAMIQUIZ IBANEEZ, V. El sistema verbal del español actual. Revista de la Universidad de Madrid: Homenaje a Menéndez Pidal, Madrid, v.18, p.242-67, 1969.

LIPSKI, J. M. El español de América. Madrid: Cátedra, 1994.

MARCUSCHI, L. A. Produção textual, análise de gêneros e compreensão. São Paulo: Parábola, 2008.

MORENO DE ALBA, J. G. El español en América. Ciudad de México: FCE, 2000.

OLIVEIRA, L. C. As duas formas do pretérito perfeito em espanhol: análise de corpus. Florianópolis, 2007. 130 fls. Dissertação (Mestrado em Linguística) - Universidade Federal de Santa Catarina, Florianópolis, 2007.

RAE. Nueva gramática de la lengua española. Madrid: Espasa, 2009. vol. 1. REICHENBACH, H. The tenses of verbs. In: STEVEN, D. (Org.). Semantics: a reader. New York: Oxford University Press, 2004. p.526-33.

RIEMER, N. Introducing semantics. New York: Cambridge University Press, 2010.

RODRIGUEZ LOURO, C. Usos del Presente Perfecto y el Pretérito en el español rioplatense argentino. In: CONGRESO INTERNACIONAL DE ALFAL, 15, 2008, Montevideo. Actas del XV Congreso Internacional de ALFAL. Montevideo: Alfal, 2008. Disponível em: $<$ http://alfal.easyplanners.info/programa/programaExtendido.php? casillero $=612083000 \&$ sala_ $=$ Sala $\% 20404 \&$ dia $_{-}=$Jueves $\% 2021 \% 20$ de\%20agosto\#>. Acesso em: 22 jun. 2012.

ROJAS, E. M. La norma hispánica: prejuicios y actitudes de los argentinos en el siglo XX. In: CONGRESO INTERNACIONAL DE LA LENGUA ESPAÑOLA, 2², 2001, Valladolid. Paneles y ponencias del II Congreso Internacional de la Lengua Española. Madrid: Centro Virtual Cervantes, 2001. Disponível em: <http://congresosdelalengua.es/valladolid/ponencias/unidad_diversidad_del_espanol/1_la_ norma_hispanica/rojas_e.htm>. Acesso em: 11 jul. 2013.

. La temporalidad verbal en español. Verba: Anuário Gallego de Filología, Santiago de Compostela, v.1, p.69-149, 1974.

Relaciones entre temporalidad y aspecto en el verbo español. In: BOSQUE, I. (Org.). Tiempo y aspecto en español. Madrid: Cátedra, 1990. p.17-43. 
.; VEIGA, A. El tiempo verbal: los tiempos simples. In: BOSQUE, I.; DEMONTE, V. Gramática descriptiva de la lengua española. Madrid: Espasa, 1999. 2 vols. p.2867-934.

SANCHEZ, A. et al. (orgs.). CUMBRE - Corpus Linguistico del Espanol Contemporaneo - Fundamentos, Metodologia, y Aplicaciones. Madrid: SGEL, 1995.

VENDLER, Z. Linguistics in philosophy. Nova York: Cornell University Press, 1967.

VIDAL DE BATTINI, B. E. El español de la Argentina: Estudio destinado a los maestros de las escuelas primarias. Buenos Aires: Consejo Nacional de Educación, 1964. 


\section{5 \\ A VARIAÇÃO DA CONCORDÂNCIA VERBAL NO PORTUGUÊS POPULAR DA CIDADE DE São Carlos ${ }^{1}$}

Alexandre Monte ${ }^{2}$

\section{Introdução}

Este trabalho tem como objetivo apresentar um estudo da variação na concordância verbal de terceira pessoa do plural no português popular falado da cidade de São Carlos, localizada no interior do Estado de São Paulo, Brasil.

No Brasil, a concordância verbal é um fenômeno variável que atrai muito a atenção social e, de acordo com Bagno (2009, p. 104), é o fenômeno linguístico que mais desperta atitudes de discriminação entre os falantes urbanos letrados. Os exemplos (1-4) ilustram a realização variável da concordância, foco do presente estudo:

(1) os menino qué coisa boa viu? $(\mathrm{FNI})^{3}$

1 Este texto constitui uma versão revista e adaptada de minha dissertação de mestrado (Monte, 2007), sob orientação da professora Rosane de Andrade Berlinck.

2 Doutor em Linguística e Língua Portuguesa pelo Programa de Pós-Graduação em Linguística e Língua Portuguesa da Faculdade de Ciências e Letras da Unesp de Araraquara

3 A codificação que segue os exemplos indica as seguintes informações sobre $\mathrm{o} / \mathrm{a}$ informante: a primeira letra refere-se ao sexo ( $\mathrm{F}$ - feminino ou $\mathrm{M}$ - masculino); a segunda à escolaridade ( $\mathrm{N}$ - não alfabetizado/a ou E - EJA/formação supletiva) e a última ao nome. 
(2) eles não querem respeitá o nossos direito... (FEP)

(3) eles foi buscá a gente lá... (MNC)

(4) aí:: ... eles foru a gente ficô né?... (MEA)

Do ponto de vista exclusivamente semântico, não há diferença entre as construções que contêm as formas singulares e plurais dos verbos ilustrados acima, porque em ambos os casos a leitura é plural. No entanto, essa diferença formal se transformou - num país socialmente tão desigual como o Brasil - num pesado fator de discriminação.

Este estudo sociolinguístico procurou buscar os fatores linguísticos e sociais que estariam atuando na realização da variável. Em todos os trabalhos analisados no Brasil, pudemos constatar que é possível correlacionar a aplicação variável de concordância entre sujeito/SN e verbo tanto a fatores internos (linguísticos) quanto a fatores externos (sociais). Estamos seguros de que a concordância verbal é um fenômeno linguístico que não pode ser analisado apenas em termos de suas relações internas na gramática, mas deve ser visto como parte de um contexto sociocultural mais amplo.

Além da contribuição teórico-descritiva, não podemos deixar de ressaltar a relevância social deste trabalho, pois a concordância verbal no Brasil, como já mencionamos, é um dos fenômenos variáveis da língua que mais tem sofrido avaliação social e alimentado manifestações de preconceito e intolerância linguísticos.

\section{Pressupostos teóricos}

De acordo com Neves (2001, p. 34), um dos dois grandes marcos de alteração da história da consideração da gramática (e, por extensão, da norma), no Ocidente, ligado ao desenvolvimento da ciência linguística, foi

[...] o aparecimento dos estudos variacionistas (sociolinguística), que passaram a vincular padrões a usos, usos a registros, registros a 
eficácia, com isso obtendo reverter a avaliação, no campo da atuação linguística, de diferença, como possível deficiência, para diferença, como garantia de eficiência de comunicação. (ibidem, p. 34).

Nosso estudo foi realizado com base nos princípios teóricos da “Teoria da Variação e Mudança Linguística" (Weinreich; Labov; Herzog, 1968; Labov, 1972; 1994; 2001; 2003).

A Sociolinguística atua nas fronteiras entre língua e sociedade, focalizando os empregos concretos da língua. Os fenômenos de variação linguística são condicionados, não só por fatores internos à estrutura linguística, mas também por fatores extralinguísticos, de natureza social, ligados ao próprio falante e à situação em que a comunicação se processa.

Incorporando a variação na descrição e na teoria linguísticas, Labov $(1972 ; 1994 ; 2001 ; 2003)$ introduz alguns conceitos teórico- metodológicos de extrema importância para a análise de nosso objeto de pesquisa. Segundo o autor, todo sistema linguístico é dotado de um conjunto de regras que não podem ser violadas. A esse conjunto de leis internas se costuma dar o nome de "regras categóricas" (i.e. regras linguísticas que sempre se aplicam). Mas, além das "regras categóricas", existem as "regras semicategóricas" e as "regras variáveis".

No texto "Some sociolinguistic principles", Labov (2003, p. 241-3) explica os três tipos de regras linguísticas e a frequência com que cada tipo de regra opera.

Quadro 1 - Tipologia de regras apresentada por Labov (2003).

\begin{tabular}{|l|c|}
\hline \multicolumn{1}{|c|}{ Tipo de regra } & Frequência com que opera \\
\hline I - Categórica & $100 \%$ \\
\hline II - Semicategórica & $95-99 \%$ \\
\hline III - Variável & $5-95 \%$ \\
\hline
\end{tabular}

Fonte: Labov, 2003, p.241-3

O conceito de "regra variável" é utilizado para substituir a noção de regra opcional do Estruturalismo, uma vez que não pressupõe variação livre, mas, sim, sistemática. 
As formas linguísticas em variação em uma determinada comunidade de fala são denominadas "variantes linguísticas". Essas são definidas como formas alternativas de se dizer a mesma coisa, em um mesmo contexto. Embora sejam idênticas em seu valor referencial, as variantes podem opor-se quanto ao seu significado social e/ ou estilístico. Ao conjunto de variantes dá-se o nome de "variável linguística". Assim, a concordância verbal no português do Brasil constitui precisamente uma "regra variável", ou uma "variável linguística", que abrange duas "variantes": a presença ou a ausência de marca de plural no verbo.

\section{Procedimentos metodológicos}

Por meio de um estudo empírico e sincrônico, analisamos a variação na concordância verbal de terceira pessoa do plural na fala de vinte pessoas residentes numa comunidade da periferia urbana da cidade de São Carlos, localizada no interior do estado de São Paulo, Brasil. São jovens e adultos de 20 a 40 anos, de ambos os sexos, de procedência geográfica diversificada, diferenciados, também, com relação ao grau de escolarização: dez não alfabetizados e dez concluintes da oitava série do ensino fundamental na EJA (Educação de Jovens e Adultos).

O Quadro 2 que apresentamos a seguir resume as características dos nossos informantes.

A cidade de São Carlos está localizada no centro geográfico do estado de São Paulo. De acordo com o Censo 2010 do IBGE, ${ }^{4}$ a população de São Carlos é de 221.950 habitantes, sendo 213.061 na área urbana e 8.889 na área rural. São 108.914 homens e 113.036 mulheres. ${ }^{5}$

4 Dados obtidos do site www.ibge.gov.br.

5 O Censo 2000 do IBGE revelava uma população de 192.998 habitantes, sendo 9.565 na área rural e 183.433 na área urbana. 
Quadro 2 - Resumo das características dos informantes

\begin{tabular}{|c|c|c|c|c|}
\hline Informante & Gênero & Idade & Escolaridade & Procedência \\
\hline $\mathrm{M}$ & $\mathrm{F}$ & 30 & não alfabetizada & São Carlos / SP \\
\hline $\mathrm{N}$ & $\mathrm{F}$ & 35 & não alfabetizada & Monte Alto / SP \\
\hline $\mathrm{I}$ & $\mathrm{F}$ & 34 & não alfabetizada & São José de Piranha / PB \\
\hline $\mathrm{E}$ & $\mathrm{F}$ & 27 & não alfabetizada & Arapiraca / AL \\
\hline $\mathrm{L}$ & $\mathrm{F}$ & 25 & não alfabetizada & São Carlos / SP \\
\hline $\mathrm{S}$ & M & 31 & não alfabetizado & São Benedito do Sul / PE \\
\hline $\mathrm{J}$ & $\mathrm{M}$ & 31 & não alfabetizado & Bernardo Vieira / PE \\
\hline G & $\mathrm{M}$ & 29 & não alfabetizado & Tamboril / CE \\
\hline $\mathrm{D}$ & M & 35 & não alfabetizado & Rinópolis / SP \\
\hline $\mathrm{C}$ & M & 35 & não alfabetizado & União dos Palmares / AL \\
\hline $\mathrm{H}$ & $\mathrm{F}$ & 27 & 8asérie-EJA & Morro do Chapéu / BA \\
\hline $\mathrm{Z}$ & $\mathrm{F}$ & 23 & $8^{\mathrm{a}}$ série - EJA & Manhuaçu / MG \\
\hline $\mathrm{P}$ & $\mathrm{F}$ & 38 & $8^{\mathrm{a}}$ série-EJA & Alto Piquiri / PR \\
\hline $\mathrm{W}$ & $\mathrm{F}$ & 22 & 8asérie-EJA & Catende / PE \\
\hline $\mathrm{R}$ & $\mathrm{F}$ & 34 & $8^{\mathrm{a}}$ série - EJA & Tanabi / SP \\
\hline A & $\mathrm{M}$ & 22 & 8asérie-EJA & Ortiqueira / PR \\
\hline $\mathrm{T}$ & $\mathrm{M}$ & 38 & 8aarie-EJA & Rubelita / MG \\
\hline $\mathrm{B}$ & $\mathrm{M}$ & 27 & 8asérie-EJA & Faxinal / PR \\
\hline $\mathrm{V}$ & M & 30 & 8a série-EJA & Canindé / CE \\
\hline $\mathrm{O}$ & $\mathrm{M}$ & 35 & $8^{\mathrm{a}}$ série $-\mathrm{EJA}$ & Sarutaiá / SP \\
\hline
\end{tabular}

Em relação à população que reside na comunidade periférica estudada, tomamos aqui como base as vinte entrevistas realizadas por nós e, também, o relatório de abril de 2006 de uma pesquisa censitária. Essa pesquisa censitária foi solicitada pela Secretaria Municipal de Educação da Prefeitura de São Carlos/SP, com o objetivo de identificar demandas em educação e construir indicadores sociais mínimos para subsidiar o planejamento de políticas públicas para a região. A comunidade estudada compreende os bairros Cidade Aracy 1, Cidade Aracy 2, Antenor Garcia e Presidente Collor. Foram realizadas 4.006 entrevistas e o número total de moradores indicado foi de 15.604 , distribuídos pelas quatro regiões. 
Mais de $42 \%$ das famílias vieram de outras regiões do estado de São Paulo ou de outros estados. É possível verificar que questões relacionadas à moradia, ao emprego, enfim, à condição de vida, são os principais fatores que impulsionaram grupos familiares a deixar seu local de origem. As dificuldades nesse processo de migração não se encerram quando os retirantes encontram um lugar para se fixar. Muitas famílias sofrem as consequências da economia excludente, sobrevivendo do emprego informal e de ajudas de entidades assistenciais ou de voluntários.

As entrevistas sociolinguísticas informais foram realizadas por nós de modo que se aproximassem da língua falada do dia a dia. Feitas todas as transcrições das entrevistas, os dados foram levantados e, após a codificação conforme os fatores linguísticos e sociais estabelecidos, submetidos ao conjunto de programas computacionais Varbrul (cf. Pintzuk, 1988; Sankoff, 1988) e ao programa Goldvarb 2001 (Varbrul para ambiente Windows).

A presente pesquisa contempla o estudo com sujeitos/SNs simples (de um só núcleo) de estrutura simples de terceira pessoa do plural.

\section{Análise e resultados}

Como trabalhamos com pessoas de nula e pouca escolaridade, fato que justifica dizermos que são falantes do português popular, já era esperada a baixa frequência da concordância verbal. Do total de mil ocorrências de terceira pessoa do plural estudadas no nosso corpus, 753 (75\%) não trazem a marca formal de plural nos verbos, sendo que apenas 247 (25\%) apresentam a marca formal de plural. Apesar de predominar a não concordância, os resultados evidenciam que estamos diante de um caso de variação. Vale destacar que esses resultados são o inverso de outras amostras com mais escolarização. Em Scherre e Naro (1997), por exemplo, há 73\% de presença de concordância e $27 \%$ de não concordância, mas os efeitos linguísticos e sociais, em termos de tendências, são os mesmos, o que se reflete nos pesos relativos. 
Os programas Varbrul e Goldvarb 2001, que também efetuam a seleção das variáveis independentes estatisticamente significativas, selecionaram, na ordem de importância, os seguintes grupos de fatores:

1) grau de saliência fônica da oposição entre as formas verbais do singular e do plural;

2) paralelismo formal no nível oracional;

3) presença ou ausência do "que" relativo entre o SN controlador da concordância e o verbo;

4) escolaridade;

5) gênero.

\section{Grau de saliência fônica da oposição entre as formas verbais do singular e do plural ${ }^{6}$}

O grupo de fatores saliência fônica foi o que se mostrou mais relevante na análise estatística realizada, sendo o primeiro a ser selecionado pelos programas Varbrul e Goldvarb 2001.

A escala utilizada na análise, proposta por Lemle e Naro (1977), ${ }^{7}$ compreende dois níveis (conforme a intensidade dos segmentos fonéticos que realizam a oposição), e seis classes (conforme a crescente diferença material entre as formas verbais do singular e do plural):

1NÍVEL (menos saliente): contém os pares cujos segmentos fonéticos que realizam a oposição são inacentuados (não marcados) em ambos os membros. Estão em sílaba átona.

CLASSE R: verbos regulares. A diferença entre singular e plural reside na nasalidade (envolve só nasalização ou nasalização e mudança na qualidade da vogal na forma plural). Exs.: fala/ falam; come/comem; era/eram; sai/saem.

6 No controle dessa variável, foram desconsideradas as vinte ocorrências com sujeito/SN posposto ao verbo. A categoria de sujeito/SN posposto apresentou $100 \%$ de não concordância. Como o programa que gera o cálculo do peso relativo não trabalha com fatores sem variação, quando temos knockout, foi necessário eliminar essas ocorrências.

7 A escala de saliência fônica foi reformulada por Naro em 1981. 
CLASSE V: a diferença entre o singular e o plural reside numa vogal final átona, possivelmente nasalada (nasalização e acréscimo de segmento na forma plural). Exs.: faz/fazem; quer/querem; diz/dizem; traz/trazem.

2NÍVEL (mais saliente): contém os pares cujos segmentos fonéticos com valor mórfico são acentuados (são marcados) em pelo menos um membro da oposição.

CLASSE L: elemento vocálico tônico oral no singular, em contraste com ditongo tônico nasal no plural. Envolve ditongação e/ou mudança na qualidade da vogal na forma plural. Exs.: está/estão; dá/dão; vai/vão.

CLASSE E: Pretéritos Perfeitos regulares, independentemente da conjugação; o acento recai na vogal temática. Exs.: falou/ falaram; vendeu/venderam; partiu/partiram.

CLASSE F: Pretéritos Perfeitos irregulares, com variação no grau de abertura da vogal tônica, em ambas as formas do singular e do plural. Exs.: trouxe/trouxeram; fez/fizeram; teve/ tiveram; veio/vieram; deu/deram.

CLASSE W: forma completamente distinta para o singular e o plural. Ex.: é/são.

Os resultados expostos na Tabela 1 confirmam a hipótese formulada e vêm corroborar os de outros estudos.

Tabela 1 - Frequência e peso relativo de concordância verbal conforme o grau de saliência fônica da oposição entre as formas verbais do singular e do plural.

\begin{tabular}{l|l|l}
\hline \multicolumn{1}{c|}{ Fatores } & Frequência & PR \\
\hline $\mathbf{R}$-fala/falam & $12 / 529=2 \%$ & 0,13 \\
\hline $\mathbf{V}$-quer/querem & $10 / 71=14 \%$ & 0,49 \\
\hline
\end{tabular}

\begin{tabular}{l|c|c}
\hline $\mathbf{L}-$ vai/vão & $90 / 169=53 \%$ & 0,90 \\
\hline $\mathbf{E}$-falou/falaram & $73 / 128=57 \%$ & 0,93 \\
\hline $\mathbf{F}$-teve/tiveram & $22 / 30=73 \%$ & 0,97 \\
\hline $\mathbf{W}-e ́ /$ são & $40 / 53=75 \%$ & 0,98 \\
\hline Total & $247 / 980=25 \%$ & Range 85 \\
\hline
\end{tabular}


Os nossos resultados revelam claramente que os verbos cujos segmentos fonéticos que realizam a oposição são inacentuados (oposição menos saliente) tendem a não trazer a marca formal de plural. Já quando a diferença entre a forma singular e plural é muito perceptível, temos um forte fator condicionante para os verbos serem marcados.

Observando a escala de saliência fônica utilizada na nossa análise, percebemos nitidamente a crescente frequência de concordância à medida que a saliência verbal vai aumentando. Ao passar de $\mathrm{V}$ (quer/querem) para L (vai/vão), há um salto bastante grande; ou seja, o maior salto no índice de concordância ocorre entre os níveis 1 e 2 da hierarquia oposicional. Esse salto é de 39 pontos percentuais em termos de frequência e $41 \mathrm{em}$ termos de peso relativo.

\section{Paralelismo formal ${ }^{8}$}

Esse grupo de fatores se baseia no estudo de Scherre e Naro (1993). Os pesquisadores analisaram o paralelismo formal no nível oracional (marcas no sujeito) e no nível discursivo (marcas no verbo). Em nossa pesquisa, analisamos apenas o paralelismo formal no nível oracional, que abrange duas categorias, ilustradas a seguir:

a) presença da forma de plural explícita no último (ou único) elemento do SN sujeito:

(5) eles num gosta dos pobre (FNL)

(6) nas pessoas que tão dormindo debaixo da ponte... (FEP)

(7) as/ as senhoras assim cantam... (FEH)

b) presença da forma zero de plural no último elemento do $\mathrm{SN}$ sujeito:

(8) as criança_vai querê fazê também né?... (FNM)

8 No controle dessa variável, foram desconsideradas as 277 ocorrências com sujeito nulo e as vinte ocorrências com sujeito/SN posposto ao verbo. 
(9) mais já os menino_é mais espertos do que ela $(\mathrm{FEH})$ (10) e os médico_não achava o pobrema... (MET)

O grupo de fatores paralelismo formal também se mostrou muito relevante na análise estatística realizada, sendo o segundo a ser selecionado pelos programas Varbrul e Goldvarb 2001. Os resultados gerais obtidos para esse grupo vêm expostos na Tabela 2 .

Tabela 2 - Frequência e peso relativo de concordância verbal segundo o paralelismo formal no nível oracional.

\begin{tabular}{l|c|c}
\hline \multicolumn{1}{c|}{ Fatores } & Frequência & PR \\
\hline $\begin{array}{l}\text { - forma de plural explícita no último (ou } \\
\text { único) elemento }\end{array}$ & $148 / 520=28 \%$ & 0,62 \\
\hline - forma de plural zero no último elemento & $20 / 183=11 \%$ & 0,19 \\
\hline Total & $168 / 703=24 \%$ & Range 43 \\
\hline
\end{tabular}

Os valores mostram que a hipótese foi confirmada: há realmente maior frequência de realização de concordância verbal quando a marca formal de plural está presente no último ou único elemento do SN (28\%). A frequência cai para 11\% quando temos ausência da marca formal de plural no último elemento. Essa tendência fica mais evidente ao analisarmos os pesos relativos: 0,62 quando o último ou único elemento do SN apresenta marca explícita de plural e 0,19 quando o último elemento apresenta zero.

Lembramos que nossa hipótese era justamente essa: marcas levam a marcas e zeros levam a zeros ou, em termos mais gerais, tem se verificado uma tendência de formas gramaticais semelhantes ocorrerem juntas (Scherre e Naro, 1993, p.2).

\section{Presença ou ausência do "que" relativo"}

Nesse grupo de fatores, separamos o "que" relativo dos demais elementos intervenientes que possam ocorrer entre o SN controla-

9 No controle dessa variável, foram desconsideradas as 277 ocorrências com sujeito nulo e as vinte ocorrências com sujeito/SN posposto ao verbo. 
dor da concordância e o verbo. Acreditamos, assim como Naro e Scherre (2003), que a presença do pronome relativo "que" inibe as chances de o verbo apresentar marca explícita de plural. O grupo compreende duas categorias:

a) ausência do "que" relativo:

(11) eles não se abateru não (MNC)

(12) eles também não fazem por conta (MEO)

b) presença do "que" relativo:

(13) tem uns home que vai imprensando lá (MNS)

(14) tá certo que tem pessoas que bate muito em criança né?... (MET)

$\mathrm{Na}$ ordem de relevância, esse grupo de fatores foi o terceiro selecionado.

Tabela 3 - Frequência e peso relativo de concordância verbal em função da presença ou ausência do "que" relativo.

\begin{tabular}{l|c|c}
\hline \multicolumn{1}{c|}{ Fatores } & Frequência & PR \\
\hline - presença do "que" relativo & $18 / 108=17 \%$ & 0,20 \\
\hline - ausência do "que" relativo & $150 / 595=25 \%$ & 0,56 \\
\hline Total & $168 / 703=24 \%$ & Range 36 \\
\hline
\end{tabular}

Os resultados da Tabela 3 mostram que a presença do "que" relativo inibe, realmente, a marca explícita de plural nos verbos. A diferença entre as duas categorias chega a 36 em termos de peso relativo, o que nos leva a afirmar que constitui fator importante nos estudos de concordância verbal de terceira pessoa do plural.

\section{Posição do sujeito/SN em relação ao verbo}

Os pioneiros no estabelecimento dessa variável foram Lemle e Naro (1977). Os pesquisadores postularam o princípio da saliência 
posicional, ou seja, as relações sintáticas entre sujeito/SN e verbo ficam mais salientes quando o sujeito/SN determinante e controlador da concordância verbal antecede o verbo determinado e candidato à concordância.

$\mathrm{O}$ sujeito/SN posposto aparece em vinte ocorrências do nosso corpus e em nenhuma delas o verbo traz a marca de plural explícita, como ilustram os exemplos:

(15) acho que tá certo eles mesmo... (MEO)

(16) onde fica os velhinho lá (MEV)

(17) mais deu esse horário... meio dia uma hora... acabô as consulta (FEZ)

(18) então... chegava os moleque... (MEV)

Outros estudos pesquisados (cf. Naro, 1981; Rodrigues, 1987; Berlinck, 1988; Vieira, 1995; Monguilhott e Coelho, 2002; Gameiro, 2005; Rubio, 2008; entre outros) também revelam que a não concordância com sujeito posposto é muito alta.

Lê-se em Berlinck (1988. p.97-8, grifo da autora):

[...] a quase categoricidade com que a ausência de concordância se associa à $\mathrm{V} \mathrm{SN}$ e a manutenção desse resultado em relação aos demais fatores confirmam sua relevância e justificam a seleção do fator como explanatoriamente forte. Essa associação tem servido de argumento favorável à tese do caráter "menos subjetivo" do sujeito (ou SN) que ocorre em V SN, uma vez que a concordância verbal sempre foi considerada uma das propriedades formais definidoras da função-sujeito.

Monguilhott e Coelho (2002) e Gameiro (2005) concluem que o sujeito posposto ao verbo passa a ser encarado como objeto pelo falante, que não realiza a concordância, já que não o considera sujeito da sentença.

Bagno (2009, p.113), em defesa do português brasileiro, afirma que a não concordância com o sujeito posposto é um caso exemplar de mudança linguística irreversível. 
Se na língua escrita clássica os exemplos são esporádicos, na fala brasileira atual a frequência de uso dessa regra beira os cem por cento. Por isso, não adianta nada lutar contra ela: é dar murro em ponta de faca. O mais democrático a fazer é admitir que a concordância do verbo com o sujeito posposto (seja ele composto ou simples) é variável, e que a não concordância é uma opção tão adequada quanto a concordância. Trata-se, simplesmente, de optar por duas análises sintáticas, igualmente válidas: (1) o elemento posposto ao verbo é o sujeito da oração; (2) o elemento posposto ao verbo é objeto de um verbo impessoal. Ah, como é simples e, ao mesmo tempo, difícil alcançar a felicidade!

\section{Escolaridade ${ }^{10}$}

Vale ressaltar, primeiramente, as condições de ensino dos informantes escolarizados da nossa amostra. Quando falamos em condições, não queremos dizer que o ensino é ou foi de má qualidade, mas que se trata de pessoas jovens e adultas que estavam tendo uma formação escolar supletiva. A especificidade desse grupo é apontada por Bortoni-Ricardo (2008. p.375, grifos nossos):

O indivíduo de pouca cultura formal possivelmente só chegará a ter consciência do caráter estigmatizado da concordância não padrão depois de um período de escolarização e de convívio com o dialeto de classe média urbana. Não se pode precisar a duração desse período sem que se proceda a estudos experimentais. Podemos, porém, prever que esse indivíduo adotará a certa altura de sua formação escolar supletiva as normas de avaliação da classe mais alta, mas tenderá sempre a usar a regra de concordância padrão com menos frequência, pois ele a assimilou tardiamente.

10 No controle dessa variável, foram desconsideradas as 20 ocorrências com sujeito/SN posposto ao verbo (100\% de não concordância). 
É sabido que na EJA (Educação de Jovens e Adultos), a cada seis meses, o aluno conclui uma série. Já no ensino regular, uma série corresponde a um ano de estudo. No momento das entrevistas, os nossos informantes estavam cursando a oitava série na EJA. Como cada um deles possui uma experiência de vida muito diferente, não tivemos conhecimento quanto aos intervalos de tempo em que eles ficaram longe da escola. Com base em um levantamento a respeito dos motivos pelos quais eles pararam de estudar, constatou-se que são diversos: tiveram de trabalhar e o horário coincidia com o horário das aulas; estavam cansados e desmotivados; não gostavam da escola; alguns tiveram problemas de saúde e muitas mulheres ficaram grávidas ou tiveram de parar por causa dos filhos/netos.

Tendo em conta esse quadro de escolarização, parece-nos que os resultados da análise se mostram ainda mais significativos. Diferenças quanto ao grau de escolaridade dos informantes se revelaram significativamente atuantes na variação da concordância verbal, como mostram os índices na Tabela 4:

Tabela 4 - Frequência e peso relativo de concordância verbal segundo o grau de escolaridade do informante.

\begin{tabular}{l|c|c}
\hline \multicolumn{1}{c|}{ Fatores } & Frequência & PR \\
\hline - não alfabetizados & $94 / 491=19 \%$ & 0,40 \\
\hline - escolarizados (EJA) & $153 / 489=31 \%$ & 0,60 \\
\hline Total & $247 / 980=25 \%$ & Range 20 \\
\hline
\end{tabular}

Como hipotetizado, vemos que há maiores chances de aplicação da concordância entre falantes escolarizados do que entre os não alfabetizados. Desse modo, da análise fica um indício de que a escolaridade, mesmo supletiva, influencia o fenômeno variável de concordância verbal. Cremos que é possível afirmar que a influência normativa da escola tem um papel importante na aquisição de formas verbais marcadas de número-pessoa; ou seja, da variedade padrão de concordância. 
Assim como Naro e Scherre (1999), resolvemos analisar o cruzamento das variáveis escolaridade e saliência fônica, a fim de verificar se a nitidez da escala da saliência fônica tem relação com os níveis de escolarização dos informantes. Os resultados se encontram na Tabela 5 e no Gráfico 1.

Tabela 5 - Frequência de concordância verbal segundo o grau de escolaridade e o grau de saliência fônica da oposição entre as formas verbais do singular e do plural.

\begin{tabular}{l|c|c}
\hline \multirow{2}{*}{\multicolumn{1}{c|}{ Fatores }} & \multicolumn{2}{|c}{ Freqüência de concordância } \\
\cline { 2 - 3 } & - não alfabetizados & - escolarizados (EJA) \\
\hline $\mathbf{R}$-fala/falam & $0 / 279=0 \%$ & $12 / 250=5 \%$ \\
\hline $\mathbf{V}$-quer/querem & $4 / 35=11 \%$ & $6 / 36=17 \%$ \\
\hline
\end{tabular}

\begin{tabular}{l|c|c}
\hline $\mathbf{L}-$ vai/vão & $35 / 76=46 \%$ & $55 / 93=59 \%$ \\
\hline $\mathbf{E}-$ falou/falaram & $31 / 68=46 \%$ & $42 / 60=70 \%$ \\
\hline $\mathbf{F}-$ teve/tiveram & $8 / 10=80 \%$ & $14 / 20=70 \%$ \\
\hline $\mathbf{W}-\dot{e} /$ são & $16 / 23=70 \%$ & $24 / 30=80 \%$ \\
\hline
\end{tabular}

Gráfico 1 - Frequência de concordância verbal segundo o grau de escolaridade e o grau de saliência fônica da oposição entre as formas verbais do singular e do plural.

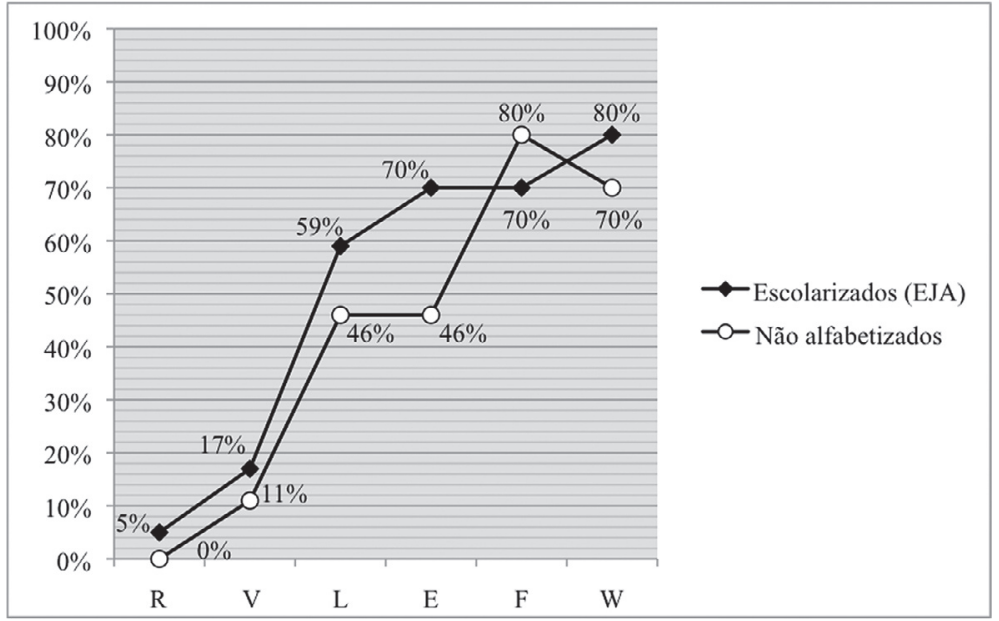


Encontramos um número maior de ocorrências na classe R, sendo 279 entre os não alfabetizados e 250 nos escolarizados. Essas ocorrências estão bem distribuídas nas duas categorias de escolaridade. Os informantes não alfabetizados não realizam qualquer concordância com verbos da classe $\mathrm{R}$. O efeito da baixa saliência mostra que, com tais verbos, as pessoas não alfabetizadas da nossa amostra deixam de concordar sujeito e verbo sistematicamente. Já nos escolarizados, podemos observar uma frequência de 5\% de concordância. É claro que a diferença não é tão significativa, mas, levando em consideração o grande número de ocorrências (279 e 250) e a baixa saliência que os verbos da classe R apresentam, é um sinal de que a escolaridade atua. Acreditamos que esse índice deva aumentar, conforme aumentarem os anos de escolaridade.

Nas classes R, V, L, E e W, os não alfabetizados realizam menos concordância verbal do que os escolarizados. Na classe $\mathrm{F}$, em que a diferença fônica das formas de singular e plural é bem perceptível, até os não alfabetizados realizam mais a concordância. Na classe W, verificamos que a diferença é de apenas dez pontos percentuais em termos de frequência. Isso indica que nas classes de verbos de oposição bem marcada, os falantes não alfabetizados também utilizam com frequência a concordância verbal.

Observamos o aumento na frequência de concordância seguindo a escala de saliência, qualquer que seja o nível de escolaridade. Esse movimento ascendente, no entanto, não anula as diferenças estabelecidas pela escolaridade, mostrando que os dois parâmetros agem conjuntamente.

O Gráfico 2 nos mostra os resultados da atuação do princípio do paralelismo juntamente com o grau de escolaridade dos nossos informantes.

Quando temos a forma de plural zero no último elemento, os índices de frequência são praticamente os mesmos nos não alfabetizados e nos escolarizados (11\% e 12\%). A diferença é notável quando temos a forma de plural explícita no último elemento. Nesse caso observamos claramente a tendência dos escolarizados a marcarem mais o verbo. Essa diferença em termos de frequência é de 17 pontos percentuais. 
Gráfico 2 - Frequência de concordância verbal segundo o grau de escolaridade e o paralelismo formal no nível oracional.

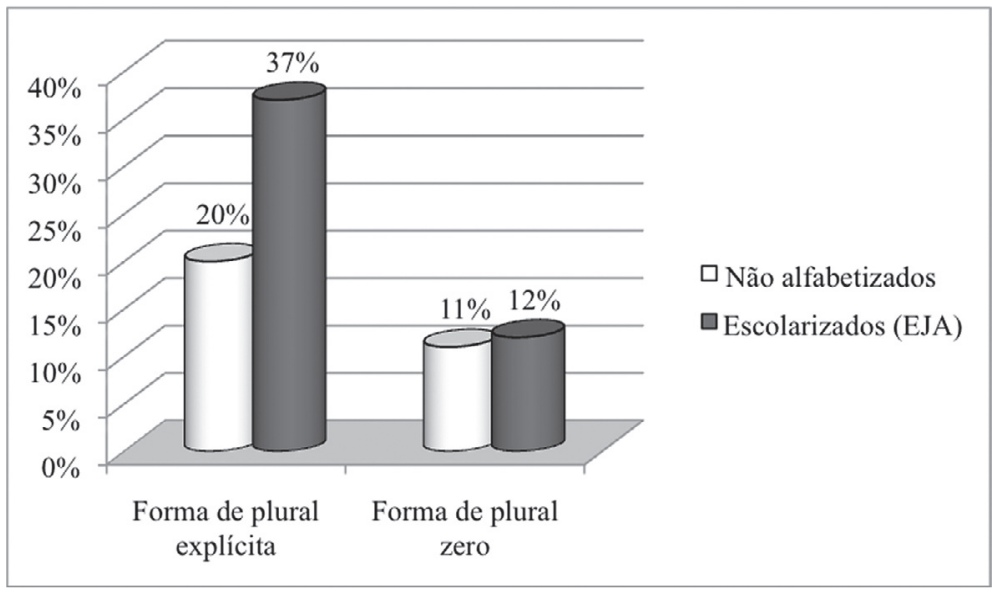

Não podemos deixar de ressaltar a importância dos cruzamentos nos estudos dessa natureza, que revelam uma confluência entre os fatores determinantes na realização de uma variável linguística.

\section{Gênero ${ }^{11}$}

A motivação para avaliar o papel do gênero sobre a variação linguística pode ser sintetizada pelas palavras de Rodrigues (1987, p.199):

As variedades linguísticas ligadas a sexo aparecem como resultado do fato de a língua, enquanto fenômeno social, estar intimamente relacionada com atitudes sociais. Homens e mulheres são socialmente diferentes, a eles são atribuídos diferentes papéis e, por isso, deles se esperam padrões de comportamento diferenciados...

11 No controle dessa variável, foram desconsideradas as vinte ocorrências com sujeito/SN posposto ao verbo (100\% de não concordância). 
A variável social gênero foi selecionada em quinto lugar pelos programas Varbrul e Goldvarb 2001, apresentando o menor range.

Tabela 6 - Frequência e peso relativo de concordância verbal conforme o gênero.

\begin{tabular}{l|c|c}
\hline \multicolumn{1}{c|}{ Fatores } & Frequência & PR \\
\hline- masculino & $121 / 488=25 \%$ & 0,45 \\
\hline- feminino & $126 / 492=26 \%$ & 0,55 \\
\hline Total & $247 / 980=25 \%$ & Range 10 \\
\hline
\end{tabular}

Se analisarmos somente as frequências puras, não conseguiremos enxergar a atuação da variável gênero, já que homens e mulheres apresentam, praticamente, as mesmas frequências. Em termos de peso relativo, a diferença é um pouco maior (range de 10) e a variável foi selecionada como estatisticamente relevante.

As mulheres da nossa amostra demonstraram um pouco mais de sensibilidade à variante de prestígio. Em relação à concordância verbal de terceira pessoa do plural, muitas pesquisas sociolinguísticas com dados do português brasileiro já comprovaram a preferência feminina pela variante padrão.

\section{Procedência do informante}

Antes de iniciarmos este trabalho com a comunidade, pretendíamos colher amostra da língua falada exclusivamente dos são-carlenses, ou moradores da cidade desde os 5 anos de idade, com vistas a desenvolver um trabalho de análise de uma comunidade homogênea quanto à procedência. Mas a realidade mostrou-se bastante diferente: das vinte entrevistas que realizamos, nove pessoas são da região Nordeste e onze das regiões Sul e Sudeste. Dessas onze, cinco não são do estado de São Paulo e apenas duas são da cidade de São Carlos. Por isso, resolvemos controlar a procedência do informante.

Com uma diferença de apenas sete pontos percentuais em termos de frequência entre Nordeste (21\%) e Sul/Sudeste (28\%), a variável social procedência do informante foi descartada pelos programas, ou seja, não foi estatisticamente significativa. 
Tabela 7 - Frequência de concordância verbal segundo a procedência do informante.

\begin{tabular}{c|c}
\hline Fatores & Frequência \\
\hline- Nordeste & $91 / 426=21 \%$ \\
\hline- Sul/Sudeste & $156 / 554=28 \%$ \\
\hline Total & $247 / 980=25 \%$ \\
\hline
\end{tabular}

Temos um indício de que a não concordância tende a ser um traço comum a todos os não alfabetizados ou de baixa escolaridade de todas as regiões do Brasil.

\section{Reflexões finais}

Acreditamos que este trabalho tenha alcançado seu objetivo principal que é revelar, juntamente com os já existentes, a sistematicidade que existe na variação na concordância verbal de terceira pessoa do plural.

Os nossos resultados revelam uma regra efetivamente variável (cf. Labov, 2003, p.242). Dentre os fatores linguísticos atuantes, destacamos a saliência fônica da oposição singular/plural dos verbos, o paralelismo formal no nível oracional, a presença/ausência do pronome "que" relativo, a posição do sujeito/SN em relação ao verbo. A escolaridade, entre os fatores sociais, assume um papel fundamental na aquisição de uma regra de concordância que apresenta um baixo percentual de frequência em variedades populares e coloquiais no Brasil.

De acordo com Scherre e Naro (1998), é possível prever em que estruturas linguísticas e em que situações sociais os falantes são mais propensos a colocar ou não a marca formal de plural no verbo. Vamos tecer alguns comentários com base no exemplo abaixo:

(19) aquelas criança rebelde que num escuta ninguém (FNE)

Esse caso da nossa amostra é de uma informante não alfabetizada. Além da presença do "que" relativo mascarando a relação SN/ 
verbo, temos o verbo "escutar" que pertence ao primeiro nível da escala da saliência fônica (a diferença entre a forma singular e plural é pouco perceptível) e o último elemento do sintagma nominal controlador da concordância não traz a marca explícita de plural. Como podemos notar, há uma confluência de fatores favorecendo a ausência de concordância, inclusive um fator social.

Os estudos sociolinguísticos têm mostrado que a variação não é de maneira alguma aleatória. Ao contrário, é altamente estruturada. A concordância verbal é um fenômeno que não está imune à estigmatização, muito pelo contrário: se o falante não a realiza, principalmente com os verbos mais salientes da escala da saliência fônica, ele pode "sentir na pele" o preconceito linguístico existente no nosso país. Dessa forma, estudos sociolinguísticos como o nosso, além da contribuição teórico-descritiva, podem contribuir no combate ao preconceito linguístico tão arraigado na nossa sociedade.

\section{Referências bibliográficas}

BAGNO, M. Não é errado falar assim! Em defesa do português brasileiro. São Paulo: Parábola Editorial, 2009.

BERLINCK, R. A. A ordem V SN no português do Brasil: sincronia e diacronia. Campinas, 1988. 265 fls. Dissertação (Mestrado) - Instituto de Estudos da Linguagem, Universidade Estadual de Campinas, Campinas, 1988.

BORTONI-RICARDO, S. M. A concordância verbal em português: um estudo de sua significação social. In: VOTRE, S.; RONCARATI, C. (orgs). Anthony Julius Naro e a linguística no Brasil: uma homenagem acadêmica. Rio de Janeiro: 7Letras, 2008. p.362-80.

GAMEIRO, M. B. A concordância verbal na língua falada da região central do estado de São Paulo. Araraquara, 2005. 198 f. Dissertação (Mestrado) - Faculdade de Ciências e Letras, Universidade Estadual Paulista, Araraquara.

LABOV, W. Sociolinguistic patterns. Philadelphia: University of Pennsylvania Press, 1972.

Principles of linguistic change. Malden: Blackwell Publishers, 1994. v. 1: Internal factors. 
Principles of linguistic change. Malden: Blackwell Publishers, 2001. v. 2: Social factors.

LABOV, W. Some sociolinguistic principles. In: PAULSTON, C. B.; TUCKER, G. R. (eds.). Sociolinguistics: the essential readings. Malden: Blackwell Publishing, 2003. p. 234-250.

LEMLE, M.; NARO, A. J. Competências básicas do português. Relatório final da pesquisa apresentado às instituições patrocinadoras Fundação Movimento Brasileiro de Alfabetização (Mobral) e Fundação Ford. Rio de Janeiro: Mobral, Fundação Ford, 1977.

MONGUILHOTT, I. O. S.; COELHO, I. L. Um estudo da concordância verbal de terceira pessoa em Florianópolis. In: VANDRESEN, P. (org.). Variação e mudança no português falado na região sul. Pelotas: Educat, 2002. p.189-216.

MONTE, A. Concordância verbal e variação: uma fotografia sociolinguística da cidade de São Carlos. Araraquara, 2007. 118 fls. Dissertação (Mestrado) - Faculdade de Ciências e Letras, Universidade Estadual Paulista, Araraquara, 2007.

NARO, A. J. The social and structural dimensions of a syntactic change. Language, Baltimore, v. 57, n. 1, p.63-98, 1981.

; SCHERRE, M. M. P. Influência de variáveis escalares na concordância verbal. A cor das letras. Feira de Santana: Universidade Estadual de Feira de Santana, 1999. p.17-34.

A relação verbo/sujeito: o efeito máscara do que relativo. In: HORA, D.; COLLISCHONN, G. Teoria linguística: fonologia e outros temas. João Pessoa: Editora Universitária, 2003. p.383-401.

NEVES, M. H. M. As gramáticas: o usuário e a norma. In: ENCONTRO NACIONAL SOBRE GRAMÁTICAS DO PORTUGUÊS, 1., 2001, Recife. Anais... Recife: UFPE, 2001. p.28-46.

PINTZUK, S. Varbrul programs. 1988. Mimeografado.

RODRIGUES, A. C. S. A concordância verbal no português popular em São Paulo. São Paulo, 1987. 259 f. Tese (Doutorado) - Faculdade de Filosofia, Letras e Ciências Humanas, Universidade de São Paulo, São Paulo, 1987.

RUBIO, C. F. A concordância verbal na língua falada na região noroeste do estado de São Paulo. São José do Rio Preto, 2008. Dissertação (Mestrado) - Universidade Estadual Paulista, São José do Rio Preto, 2008.

SANKOFF, D. Variable rules. In: AMMON, U.; DITTMAR, N.; MATTHEIER, K. J. (eds.). Sociolinguistics: an international handbook of the science of language and society. Berlin: Walter de Gruyter, 1988. p.984-98. 
SCHERRE, M. M. P.; NARO, A. J. Duas dimensões do paralelismo formal na concordância verbal no português popular do Brasil. D.E.L.T.A., v. 9, n. 1, p.1-14, 1993.

A concordância de número no português do Brasil: um caso típico de variação inerente. In: HORA, D. (org.). Diversidade linguística no Brasil. João Pessoa: Ideia, 1997. p.93-114.

Sobre a concordância de número no português falado do Brasil. In: RUFFINO, G. (org.). Dialettologia, geolinguistica, sociolinguistica. In: CONGRESSO INTERNAZIONALE DI LINGUISTICA E FILOLOGIA ROMANZA, 21., 1998, Centro di Studi Filologici e Linguistici Siciliani, Universitá di Palermo. Tübingen: Max Niemeyer Verlag, 1998. v. 5, p. 509-523.

VIEIRA, S. R. Concordância verbal: variação em dialetos populares do norte fluminense. 1995. Dissertação (Mestrado) - Faculdade de Letras, Universidade Federal do Rio de Janeiro, Rio de Janeiro, 1995. WEINREICH, U.; LABOV, W.; HERZOG, M. I. Empirical Foundations for a theory of language change. In: LEHMANN, W. P.; MALKIEL, Y. (eEds.). Directions for historical linguistics. Austin-London: University of Texas Press, 1968. p.95-195. 


\title{
6 \\ O TEXTO POÉtICO NO ESTUDO DAS VOGAIS DO PORTUGUÊS ANTIGO
}

\author{
Juliana Simões Fonte ${ }^{1}$ \\ Gladis Massini-Cagliari²
}

\section{Introdução}

A proposta deste trabalho é mostrar a contribuição dos textos poéticos no estudo de momentos passados da língua que não deixaram registros orais. Diante dessa proposição, não poderíamos deixar de evocar as palavras de Mattos e Silva (2006, p.37) acerca da relevância dos textos poéticos em determinadas pesquisas linguísticas:

O fato de serem poemas de estrutura formal em versos rimados os torna fundamentais, no que concerne a estudos de história da língua, para o conhecimento de fatos fonéticos desse período, como sejam, por exemplo, questões referentes aos encontros entre vogais (hiatos/ditongos), ao timbre vocálico (abertura/fechamento), vogais e ditongos nasais/orais.

1 Doutora em Linguística e Língua Portuguesa pela Faculdade de Ciências e Letras da Unesp, campus de Araraquara.

2 Professora da Faculdade de Ciências e Letras da Unesp, campus de Araraquara. 
Neste trabalho, vamos discorrer sobre as vogais tônicas do português antigo, mostrando que as rimas da poesia remanescente de períodos passados da língua podem fornecer pistas satisfatórias sobre a pronúncia da época, principalmente no que se refere à diferença de timbre entre as vogais médias de antanho.

Sabe-se que o sistema vocálico do português atual, em posição tônica, apresenta quatro vogais médias: duas anteriores, /e/ e / $/ \varepsilon /$, e duas posteriores, /o/ e / / , representadas, na escrita, por apenas dois grafemas, $<\mathrm{e}>\mathrm{e}<\mathrm{O}>$. No português atual, portanto, a diferença de timbre entre as vogais médias tônicas é fonológica (ex.: $o \mathrm{~d} / \mathrm{e} / \mathrm{do}$, eu $d / \varepsilon / d o, o / o /$ lho, eu /o/lho). No que diz respeito ao português antigo, como o sistema de escrita não atribui símbolos distintos para representar vogais médias abertas e fechadas, torna-se indispensável, na pesquisa sobre o timbre vocálico, a consulta às rimas empregadas na poesia de então.

Tendo em conta essa asserção, vamos analisar, no presente estudo, as rimas empregadas em textos poéticos remanescentes dos séculos XIII e XVI, com o intuito de obter informações sobre a realização das vogais médias portuguesas em diferentes períodos da história da língua: a primeira fase do português arcaico (doravante, PA) e o início do português moderno (cf. Leite De Vasconcellos, 1959; Silva Neto, 1956; Coutinho, 1974; Câmara Jr., 1979[1975]).

Como corpora para esta pesquisa, foram consideradas as Cantigas de Santa Maria (doravante, CSM) de Afonso X, para o século XIII, e Os Lusíadas de Camões, para o século XVI.

As CSM foram escritas na segunda metade do século XIII, em galego-português, com o intuito de louvar a Virgem Maria e narrar seus milagres. Não se sabe, ao certo, quem compôs as 420 cantigas que integram os manuscritos remanescentes, ${ }^{3}$ mas a autoria costuma ser atribuída a D. Afonso X, o Sábio, então rei de Leão e Castela, por ter sido ele o idealizador da obra (cf. Parkinson, 1998). Para

3 São quatro os códices contendo a coleção das CSM: dois deles pertencem à Biblioteca del Monasterio de El Escorial, na Espanha; o terceiro está conservado na Biblioteca Nacional de Madrid; e o último pertence à Biblioteca Nazionale Centrale de Florença (Itália). 
Leão (2007, p.21), esse cancioneiro mariano é "de longe a maior e mais rica coleção produzida nos vernáculos românicos da Idade Média sobre esse tema".

Os Lusíadas, obra épica de Camões composta por dez cantos e 1102 estrofes, narram a viagem de Vasco da Gama às Índias, em meio a tantas peripécias e infortúnios. Publicada pela primeira vez em 1572, a epopeia camoniana representa um clássico da literatura portuguesa, uma obra-prima que serviu de referência na formação do português padrão, inclusive no que concerne à ortografia da língua (cf. Souza, 2009).

A metodologia adotada neste estudo baseia-se no mapeamento e análise de todas as rimas empregadas nas CSM e em Os Lusíadas, que envolvam uma vogal média na sílaba tônica. Tendo em conta que uma única letra pode estar associada a mais de um fonema, analisamos as possibilidades e impossibilidades de rima, nos corpora referidos, entre vogais representadas por um mesmo grafema, para chegar aos resultados pretendidos.

Na subseção a seguir, estão apresentados e discutidos os dados obtidos por Fonte (2010), a partir da observação das rimas das CSM. A segunda subseção traz os resultados desta pesquisa referentes à análise das rimas empregadas em Os Lusíadas.

\section{As vogais médias nas rimas das Cantigas de Santa Maria}

Neste item do trabalho, estão indicados os resultados obtidos por Fonte (2010) em sua análise das rimas empregadas nas 420 CSM, de Afonso X. Partindo do rimário das cantigas afonsinas, elaborado por Betti (1997), Fonte (2010) fez um levantamento de todas as rimas envolvendo vogal média na sílaba tônica e, em seguida, investigou a ocorrência de vocábulos que não rimavam entre si, apesar de apresentarem terminações idênticas. A autora verificou, a partir desse trabalho, que algumas terminações podiam claramente ser divididas em dois grupos rimantes. 
Segundo Fonte (ibidem), nas CSM, verbos no infinitivo, tais como comer, vencer, querer, prometer, vender etc., e o substantivo prazer, por exemplo, não rimam com alguns verbos irregulares da segunda conjugação, flexionados no futuro do subjuntivo, tais como disser, quiser, souber etc., ou, no caso do verbo querer, flexionado na terceira pessoa do singular do presente do indicativo (quer), nem com o substantivo moller (mulher).

Da mesma forma, de acordo com Fonte (ibidem), verbos regulares da segunda conjugação, flexionados na terceira pessoa do singular do pretérito mais-que-perfeito do indicativo, tais como prendera, prometera, vendera etc., não rimam com alguns verbos irregulares de mesma conjugação, também flexionados na terceira pessoa do singular do pretérito mais-que-perfeito do indicativo, tais como dissera, trouxera, quisera etc., nem com a forma verbal era ou com o substantivo fera. O mesmo vale para as formas correspondentes no plural: encolleran (encolheram) e meteran (meteram) não rimam com verbos como poseran (puseram), fezeran (fizeram), manteveran (mantiveram) e eran (eram), por exemplo.

No caso da terminação -eron, presente nos verbos de segunda conjugação flexionados na terceira pessoa do plural do pretérito perfeito do indicativo, Fonte (ibidem) verificou que formas regulares como morreron (morreram), prenderon (prenderam), perderon (perderam), entre outras, não rimam, nas CSM, com verbos irregulares como fezeron (fizeram), quiseron (quiseram) e disseron (disseram).

Para a terminação -esse, presente em verbos flexionados no pretérito imperfeito do subjuntivo, Fonte (2010) também encontrou dois grupos rimantes: um constituído por verbos regulares como morresse, perdesse e vivesse, e outro composto por verbos irregulares como trouxesse, quisesse e soubesse.

Para Fonte (ibidem), a impossibilidade de rima entre os termos acima referidos pode ser interpretada como um indício de que havia, em cada terminação, grafemas idênticos representando fonemas distintos. Corrobora essa interpretação o fato de que, no português atual, verifica-se essa mesma divisão: a vogal tônica, em comer, vencer, vendera $(m)$, prometera $(m)$, encolheram, morresse, é 
fechada (/e/), enquanto que, em disser, quiser, quer, dissera, era, trouxera $(m)$, fizeram, quisesse, é aberta $(/ \varepsilon /)$.

Os dados de Fonte (ibidem) apontam, pois, para uma semelhança entre o sistema vocálico do século XIII e o sistema vocálico do português atual, pelo menos no que diz respeito às vogais tônicas da língua. Por meio dessa pesquisa, a autora confirmou, para a primeira fase do PA, uma distinção de timbre entre as vogais médias, em posição acentuada.

Por outro lado, vale observar que Fonte (ibidem) também constatou algumas diferenças entre o galego-português e o português atual. A autora registrou, no corpus analisado, a ocorrência de rima entre termos que apresentam, no português de hoje, vogais tônicas diferentes, em termos fonológicos. Da mesma forma, a estudiosa registrou a impossibilidade de rima entre terminações que apresentam exatamente os mesmos fonemas, no português atual. Compõem o primeiro caso as terminações -eja, -ela e -essa, entre as vogais médias anteriores, e as terminações -ogo, -or e -osa, entre as vogais médias posteriores. A terminação -eu(s) integra o segundo caso. Ao investigar a origem latina da vogal tônica presente em cada uma das terminações, Fonte (ibidem) constatou que todos esses casos de rima poderiam ser explicados historicamente.

No caso da terminação - eu, a autora verificou que pronomes como eu, meu, seu e teu, além do substantivo judeu, rimam entre si, nas CSM, mas jamais aparecem rimando com verbos de segunda conjugação flexionados na terceira pessoa do singular do pretérito perfeito do indicativo, ${ }^{4}$ tais como morreu, comeu etc., ou com o substantivo sandeu. A impossibilidade de rima entre esses vocábulos que, no português atual, apresentam terminações idênticas, em termos fonológicos, indica que, no século XIII, a situação era outra. De fato, a etimologia dos pronomes eu (lat. égo) e meu (lat. měu), por exemplo, assim como a do substantivo judeu (lat. iudaeu), leva-nos a acreditar que, nos primórdios da língua, a vogal média desses termos era

4 O verbo dar, de primeira conjugação, quando flexionado na terceira pessoa do singular do pretérito perfeito do indicativo (deu), é o único que aparece rimando, nas CSM, com os pronomes eu, meu, teu etc. 
$\operatorname{aberta}(/ \varepsilon /)$, já que, de acordo com a regra de substituição do sistema vocálico latino pelo português, fartamente descrita pelas gramáticas históricas e manuais de Filologia da língua, ě e ae latinos originaram, no português, uma vogal média aberta, na posição tônica.

É importante lembrar que estudiosos como Williams (1975[1938], p.45), Silva Neto (1952, p.413) e Cunha (1985; 1991) já haviam considerado a possibilidade de esses termos apresentarem, no português antigo, timbres vocálicos diferentes do atual. Os dados de Fonte (2010) confirmam, portanto, a hipótese levantada por estudos anteriores de que houve, ao longo da história da língua, uma mudança no timbre vocálico dos termos referidos. O trabalho da autora mostra, ainda, que a forma plural desses termos (meus, teus, seus, judeus etc.) aparece rimando, nas CSM, com o substantivo Deus (lat. děus) - o que nos permite incluir mais um caso de mudança de timbre vocálico, entre os dados já mencionados.

Fonte (ibidem) também registrou, nas CSM, em alguns poucos casos, o emprego da terminação - eo em verbos de segunda conjugação flexionados na terceira pessoa do singular do pretérito perfeito do indicativo (ex.: viveo, recebeo, comeo, meteo). A pesquisadora verificou que esses verbos rimam entre si, nas cantigas medievais religiosas, mas jamais aparecem rimando com termos como ceo (céu) e veo (véu), por exemplo.

O outro caso de mudança observado por Fonte (ibidem) envolve a terminação - eja. De acordo com a autora, o substantivo inveja (lat. invĭdia) rima, nas cantigas afonsinas, com os verbos seja e deseja. Tomando como base a regra de substituição das vogais latinas pelas portuguesas, segundo a qual $\breve{l}$ latino originou, no português, uma vogal média fechada (/e/), a pesquisadora infere que, no século XIII, o substantivo inveja era pronunciado com uma vogal média fechada (/e/), que se teria tornado aberta, ao longo da história da língua, por influência do - $a$ átono final. ${ }^{5}$

5 Segundo Mateus e Andrade (2000, p. 19), na variedade padrão de Lisboa, [ [ ] sempre substitui $[e]$ tônico e, por vezes, $[\varepsilon]$, diante de consoante palatal na

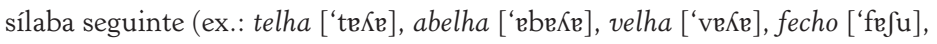
cereja [si'reze], senha ['seye], venho ['veyu]). 
Os dados de Fonte (ibidem) sugerem, ainda, que também a vogal média anterior presente no pronome demonstrativo essa (lat. ıрsa) e no substantivo promessa (lat. promıssa) era pronunciada, no século XIII, com um timbre diferente do atual. Segundo a autora, esses termos aparecem rimando, nas CSM, com abadessa e condessa. A mudança, nesse caso, também teria sido provocada, ao que tudo indica, pela influência da vogal átona final.

Com relação à terminação - ela, Fonte (ibidem) mostra que os pronomes ela (lat. îlla) e aquela (lat. eccu îlla), assim como o substantivo donzela (lat. domnicílla), rimam, nas CSM, com formas verbais acompanhadas de clíticos (o pronome pessoal átono $a$ ) tais como: vencê-la, movê-la, prendê-la. Diante dessa possibilidade de rima, e tomando como base a origem histórica da vogal média, em cada termo, a autora considerou a hipótese de esses vocábulos serem pronunciados com um timbre vocálico diferente do atual no século XIII (ex.: /e/la, aqu/e/la, donz/e/la). Por outro lado, como esses termos também aparecem rimando, no corpus referido, com vocábulos como bela (lat. béllus) e capela (lat. capélla), por exemplo, Fonte (ibidem) reconsiderou a hipótese, fazendo algumas ressalvas. Talvez seja o caso de dizer que, naquele momento da língua, ocorriam as duas pronúncias (com [e] e com $[\varepsilon]$ ), e que essa variação seria o reflexo de uma mudança em curso que originou o timbre vocálico atual desses termos.

No tangente às terminações com vogal média posterior, merece destaque o caso dos adjetivos comparativos melhor (lat. meliōre), pior (lat. peiōre), maior (lat. maīōe) e menor (lat. minōre), que rimam, nas CSM, conforme mostram os dados de Fonte (ibidem), com termos como amor e senhor, entre outros, cuja vogal média, na posição tônica, é fechada. Nesse mesmo grupo rimante, estão incluídos o substantivo redor e seus derivados (ex.: arredor, derredor). Novamente, baseando-se na origem histórica de cada termo, Fonte (ibidem) sugere que a vogal tônica, presente em melhor, pior, maior, menor, redor, derredor e arredor, era fechada, no século XIII, já que $\bar{o}$ latino originou, no português, uma vogal média fechada, segundo a regra de substituição das vogais latinas pelas portuguesas. 
Estudos anteriores (cf. Silva Neto, 1952; Nunes, 1960; Coutinho, 1974; Ramos, 1985) já haviam considerado a possibilidade de a vogal tônica desses termos ter alterado seu timbre, no decorrer da história da língua. Mais uma vez, portanto, os dados de Fonte (2010) confirmaram a hipótese levantada pelos trabalhos precedentes.

Afiança essa hipótese o fato de o galego atual preservar a pronúncia com vogal tônica fechada para os adjetivos referidos: mai[o]r, mell[o]r, men[o]r e pe[o]r (cf. Dicionario de pronuncia da lingua galega). Pronúncia que também ocorre, ainda hoje, em determinadas variedades do $\mathrm{PE}$.

Outro possível caso de mudança apontado por Fonte (2010) envolve o sufixo -osa, presente em adjetivos como gloriosa e formosa. A autora registrou, nas CSM, rima entre esses adjetivos e o substantivo esposa. Sabendo que a vogal média da terminação -osa, nesses vocábulos, é proveniente de o latino, que originou, no português, uma vogal média fechada, as gramáticas históricas e os manuais de filologia da língua citam os adjetivos referidos, cuja vogal tônica é aberta, no português atual, como casos que representam uma exceção à regra de substituição das vogais latinas pelas portuguesas. Para Williams (1975[1938], p.51) e Coutinho (1974, p.105), a vogal média aberta, nesses adjetivos, explica-se pela influência da vogal átona final, que é responsável pela marcação do gênero feminino, nesses termos. Ramos (1985, p.92), por sua vez, acredita que, no PA, a vogal média desses adjetivos era fechada e que a mudança teria ocorrido somente por volta do século XVI. Os dados de Fonte (2010) levam-nos a acreditar que, de fato, no século XIII, a forma feminina de adjetivos como formoso, glorioso, maravilhoso etc. ainda não havia passado pelo processo de transformação que tornou aberta sua vogal média posterior, em posição acentuada.

Vale comentar que, também para esses adjetivos terminados em - osa, o galego atual, ao contrário do português, mantém a pronúncia com vogal tônica fechada: ferm[o]sa e glori[o]sa, por exemplo (cf. Dicionario de pronuncia da lingua galega).

Há que se mencionar, ainda, o caso do substantivo jogo (lat. jŏcu), que aparece rimando, nas cantigas afonsinas, tanto com o 
advérbio logo (lat. lŏcu), quanto com o substantivo fogo (lat. fŏcu), conforme revelam os dados de Fonte (2010). A pronúncia atual dos substantivos jogo e fogo também vai de encontro à regra de substituição das vogais latinas pelas vogais portuguesas, que determina que ŏ latino originou, no português, uma vogal média aberta, na posição acentuada. A explicação para o fechamento da vogal média, nesses casos, é baseada no processo tradicionalmente conhecido como metafonia, ${ }^{6}$ que atribui o fechamento da vogal média à influência da vogal átona final - o. De acordo com Fonte (ibidem), as rimas das CSM permitem-nos inferir que, na língua falada pelos trovadores, a vogal tônica desses termos ainda era aberta, não tendo ocorrido, naquele momento, o processo de metafonia que, a propósito, não alterou a pronúncia da vogal tônica do advérbio logo, que continua aberta no português atual.

Os dados de Fonte (ibidem), apresentados até aqui, constituem um testemunho importante do sistema vocálico, em posição acentuada, vigente na época dos trovadores. Por meio da análise das rimas das CSM, a autora fornece-nos um quadro geral referente à pronúncia das vogais médias tônicas, no século XIII.

A fim de obter informações sobre as vogais tônicas do século XVI e estabelecer, assim, uma comparação entre dados do PA e os dados do português moderno, analisamos, na subseção a seguir, as rimas empregadas em Os Lusíadas.

\section{As vogais médias nas rimas de Os Lusíadas}

Na presente subseção, estão arrolados os dados desta pesquisa referentes ao mapeamento e análise das rimas empregadas em $O s$

6 Os estudiosos classificam a metafonia como um processo assimilatório responsável pela mudança de timbre da vogal tônica por influência de uma vogal átona final. Para Xavier e Mateus (1990, p.245), o processo de metafonia corresponde à mudança, no timbre da vogal tônica, por assimilação ao timbre de um segmento vocálico ou semivocálico contíguo. 
Lusíadas, de Camões. Esses dados foram obtidos a partir do rimário da obra épica de Camões, elaborado por Souza (1948).

Primeiramente, fizemos um levantamento, no rimário referido, de todas as rimas de Os Lusíadas envolvendo vogal média, na sílaba tônica. Em seguida, analisamos as possibilidades e imposssibilidades de rima entre os vocábulos com terminação idêntica. Nesse ponto da pesquisa, deparamo-nos com uma certa dificuldade em dividir as terminações em dois grupos rimantes. Em Os Lusíadas, ao contrário do que vimos para as CSM, não se verifica uma nítida separação entre vocábulos de terminação idêntica que não rimam entre si. Registramos, assim, nos versos de Camões, diversos casos de rima entre termos que, no português atual, apresentam fonemas vocálicos diferentes na sílaba tônica. Também ao contrário do que observou Fonte (2010), em seus dados do século XIII, a etimologia não explica, na maior parte dos casos, a possibilidade de rima no português antigo.

Para a terminação -er, por exemplo, registramos, em Os Lusíadas, rima entre as formas verbais disser (futuro do subjuntivo), dizer (infinitivo) e saber (infinitivo):

Alem disso, o que a tudo em fim me obriga,

He não poder mentir no que disser,

Porque de feitos tais, por mais que diga,

Mais me ha de ficar inda por dizer:

Mas porque nisto a ordem leve e siga,

Segundo o que desejas de saber.

(Canto III, $5^{\text {a }}$ estrofe)

Também registramos, na obra épica de Camões, diversos casos de rima entre formas verbais regulares e irregulares que, no português atual, apresentam vogais médias diferentes na sílaba tônica. Vejamos alguns exemplos envolvendo a terminação - era, em verbos flexionados no pretérito mais-que-perfeito do indicativo e no substantivo fera: 
(02)

Não he o outro que fica tão manhoso:

Mas nas mãos vay cair do Lusitano,

Sem o rigor de Marte furioso,

E sem a furia horrenda de Vulcano,

Que como fosse debil e medroso,

Da pouca gente o fraco peito humano:

Não teve resistencia, e se a tivêra,

Mais dãno resistindo recebêra.

(Canto II, estrofe 69)

Cinco vezes a Lũa se escondêra, E outras tantas mostrâra cheio o rosto, Quando a Cidade entrada se rendêra, Ao duro cerco, que lhe estava posto.

Foy a batalha tam sanguina e fera, Quanto obrigava o firme prosuposto:

De vencedores asperos, e ousados, E de vencidos, ja desesperados.

(Canto III, estrofe 59)

Mas a fermosa armada, que viera Por contraste de vento, aaquella parte Sancho quis ajudar na guerra fera, Ia que em serviço vay, do Sancto Marte Assi como a seu pay acontecèra, Quando tomou Lisboa, da mesma arte, Do Germano ajudado Silves toma, E o bravo morador destrue e doma.

(Canto III, estrofe 88)

Para a terminação -erão, correspondente ao nosso -eram atual, também registramos, n'Os Lusíadas, rima entre verbos regulares e irregulares, conforme exemplificado a seguir: 
(05)

Cessem do sabio Grego, e do Troyano,

As navegações grandes que fizerão:

Callese de Alexandro, e de Trajano,

A fama das victorias que tiverão,

A quem Neptuno, e Marte obedecerão:

Cesse tudo o que a Musa antigua canta,

Que outro valor mais alto se alevanta.

(Canto I, $3^{\circ}$ estrofe)

E como por toda Affrica se soa,

Lhe diz, os grandes feitos que fizerão,

Quando nella ganharão a coroa

Do Reino, onde as Hesperidas viverão:

E com muitas palavras apregoa,

O menos que os de Luso merecerão:

E o mais que pela fama o Rei sabia:

Mas desta sorte o Gama respondia.

(Canto II, 103 ${ }^{\mathrm{a}}$ estrofe)

A gente que esta terra possuya

Posto que todos Etiopes erão,

Mais humana no trato parecia

Que os outros, que tão mal nos receberão:

Com bailos e com festas de alegria

Pella praya arenosa a nos vierão,

As molheres consigo e o manso gado

Que apacentavão, gordo e bem criado.

(Canto V, estrofe 62)

Os cabellos da barba, e os que decem

Da cabeça nos ombros, todos erão,

Hũs limos prenhes dagoa, e bem parecem 
Que nunca brando pentem conhecerão:

Nas pontas pendurados não falecem

Os negros Misilhões, que ali se gerão,

$\mathrm{Na}$ cabeça por gorra tinha posta

Hũa muy grande casca de Lagosta.

(Canto VI, $17^{\mathrm{a}}$ estrofe)

Os ventos erão tais, que não poderão

Mostrar mais força dimpeto cruel,

Se pera derribar então vierão

A fortissima torre de Babel:

Nos altissimos mares, que crescerão,

A pequena grandura dhum batel,

Mostra a possante nao, que move espanto

Vendo que se sostem nas ondas tanto.

(Canto VI, $74^{\mathrm{a}}$ estrofe)

Encontramos também, na obra épica de Camões, rima entre verbos regulares e irregulares com terminação -esse $(m)$, flexionados no pretérito do subjuntivo, tais como sometesse (submetesse), vivesse, recebesse, tivesse, viesse e podesse (pudesse), por exemplo. Além dos verbos, integra o grupo rimante de terminação -esse o substantivo interesse, como mostram as rimas a seguir:

Ja quiseram os Deoses que tivesse,

O Filho de Filipo nesta parte, Tanto poder, que tudo sometesse

Debaixo do seu jugo, o fero Marte:

Mas asse de soffrer que o Fado desse;

A tam poucos tamanho esforço, e arte

Queu co gram Macedonio, e Romano,

Demos lugar ao nome Lusitano?

(Canto I, $75^{\mathrm{a}}$ estrofe) 
(11)

Nem creais Nimphas nam que fama desse

A quem ao bem comum, e do seu Rei

Anteposer seu proprio interesse:

Imigo da divina e humana ley,

Nenhum ambicioso, que quisesse

Subir a grandes cargos, cantarey, So por poder com torpes exercicios Vsar mais largamente de seus vicios. (Canto VII, 84 ${ }^{\mathrm{a}}$ estrofe)

Por que se eu de rapinas so vivesse Vndivago, ou da patria desterrado, Como cres que tão longe me viesse, Buscar assento incognito e apartado? Por que esperanças, ou por que interesse, Viria esprimentando o mar yrado,

Os Antarticos frios, e os ardores

Que sofrem do Carneyro os moradores?

(Canto VIII, 67 $7^{\mathrm{a}}$ estrofe)

Por ella o solta, crendo que ali tinha Penhor bastante, donde recebesse Interesse maior do que lhe vinha, Se o Capitão mais tempo detivesse: Elle vendo que ja lhe nam convinha Tornar a terra, porque nam podesse Ser mais retido, tendo aas naos chegado Nellas estar se deixa descansado. (Canto VIII, 95 estrofe)

Quantos montes então, que derribarão As ondas que batião denodadas, 
Quantas arvores velhas arrancarão

Do vento bravo as furias indinadas:

As forçosas raizes não cuidarão

Que nunca pera o ceo fossem viradas,

Nem as fundas arêas que podessem

Tanto os mares que encima as revolvessem.

(Canto VI, 79 ${ }^{\mathrm{a}}$ estrofe)

Porem como a esta terra entam viessem,

De la do feyo Arabico outras gentes,

Que o culto Mahometico trouxessem,

No qual instituirão meus parentes,

Succedeo que pregando convertessem

O Perimal, de sabios e elloquentes,

Fazem lhe a ley tomar com fervor tanto,

Que prosupos de nella morrer sancto.

(Canto VII, $33^{\mathrm{a}}$ estrofe)

Há que se mencionar, ainda, as rimas de Os Lusíadas envolvendo verbos regulares e irregulares no futuro do subjuntivo, flexionados na segunda e terceira pessoas do plural (terminações -erdes e -erem, respectivamente). Vejamos os exemplos a seguir:

Rei tendes tal, que se o valor tiverdes

Igual ao Rei que agora alevantastes,

Desbaratareis tudo o que quiserdes,

Quanto mais a quem ja desbaratastes:

E se com isto em fim vos não moverdes,

Do penetrante medo que tomastes,

Atay as mãos a vosso vão receio,

Que eu so resistirey ao jugo alheio.

(Canto IV, $18^{\mathrm{a}}$ estrofe) 
(17)

E porque he de vassalos, o exercicio, Que os membros tem regidos da cabeça, Não quereras, pois tẽs de Rei o officio,

Que ninguem a seu Rei desobedeça:

Mas as merçes, e o grande beneficio,

Que ora acha em ti, promete que conheça

Em tudo aquillo que elle e os seus poderem,

Em quanto os rios pera o mar correrem.

(Canto II, 84 a estrofe)

No caso da terminação -este, ocorre, no Canto VI de Os Lusíadas, rima entre celeste, deste (verbo dar) e defendeste e, no Canto X, o pronome este (em contração com a preposição de) aparece rimando com as formas verbais naceste (nasceste) e fizeste:

Divina guarda, angelica, celeste,

Que os ceos, o mar e terra senhoreas,

Tu que a todo Israel refugio deste

Por metade das agoas Eritreas:

Tu que livraste Paulo e defendeste

Das Syrtes arenosas e ondas feas,

E guardaste cos filhos o segundo

Povoador do alagado e vacuo mundo.

(Canto VI, 81 ${ }^{\text {a }}$ estrofe)

Nem tu menos fugir poderas deste,

Posto que rica, e posto que assentada

La no gremio da Aurora, onde naceste,

Opulenta Malaca nomeada:

As setas venenosas que fizeste,

Os Crises com que ja te vejo armada,

Malaios namorados, Iaos valentes

Todos faras ao Luso obedientes.

(Canto X, 44 a estrofe) 
Os exemplos apontados acima já são suficientes para manifestar as diferenças entre as rimas do século XIII e as rimas do século XVI. No item anterior, referente às rimas das CSM, mostramos que, nas cantigas afonsinas, formas verbais regulares, como comer, vencer, vendera, prometera, encolheram, morresse, entre outras, não rimam com formas verbais irregulares como disser, quiser, quer, dissera, era, fizeram e quisesse, por exemplo.

Sabe-se que, no português atual, verbos irregulares como dar, estar, caber, dizer, fazer, haver, poder, querer, saber, ter, trazer, pôr e vir, em determinadas pessoas do pretérito perfeito e mais-que- perfeito do indicativo, do pretérito imperfeito do subjuntivo e do futuro do subjuntivo, apresentam uma vogal média aberta $(/ \varepsilon /)$, na sílaba tônica, diferente, portanto, da vogal média fechada (/e/), presente na sílaba acentuada de verbos regulares de segunda conjugação (ex.: aprender, beber, comer, conhecer, correr, descer, entender, esquecer, falecer, meter, morrer, perder etc.), flexionados nas formas correspondentes. Temos, assim, no português atual, para o verbo fazer, por exemplo, formas com vogal média aberta, na sílaba acen-

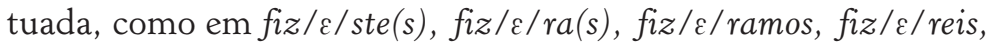

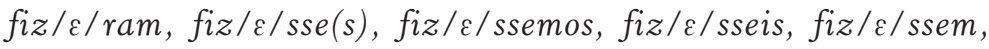

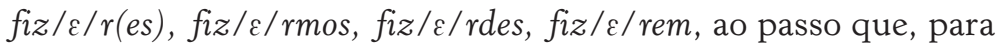
os verbos regulares, como vencer, a vogal tônica é sempre fechada: venc/e/ste(s), venc/e/ra(s), venc/e/ramos, venc/e/reis, venc/e/ram, venc/e/sse(s), venc/e/ssemos, venc/e/sseis, venc/e/ssem, venc/e/r(es), venc/e/rmos, venc/e/rdes e venc/e/rem.

As estrofes de Os Lusíadas, apontadas anteriormente, mostraram que ocorre, nos versos de Camões, rima entre muitas das formas verbais regulares e irregulares referidas acima. Se ignorássemos os dados do século XIII, apresentados na subseção anterior, poderíamos interpretar essas rimas de Camões como um indício de que a diferença de timbre entre as vogais tônicas dessas formas verbais (regulares e irregulares) é recente no português. Contudo, as rimas das CSM sugerem que, na primeira fase do PA, as formas verbais regulares e irregulares em questão já não apresentavam o mesmo fonema vocálico na sílaba acentuada. 
Para aprofundarmos a discussão sobre as diferenças entre as rimas empregadas em cada obra, cumpre apresentar os demais dados obtidos nesta pesquisa. Arrolamos, a seguir, outros exemplos de rima, em Os Lusíadas, entre termos que, no português atual, apresentam fonemas vocálicos distintos na posição acentuada. Em (20), estão indicadas as rimas envolvendo vogal média anterior e, em (21), as terminações com vogal média posterior:

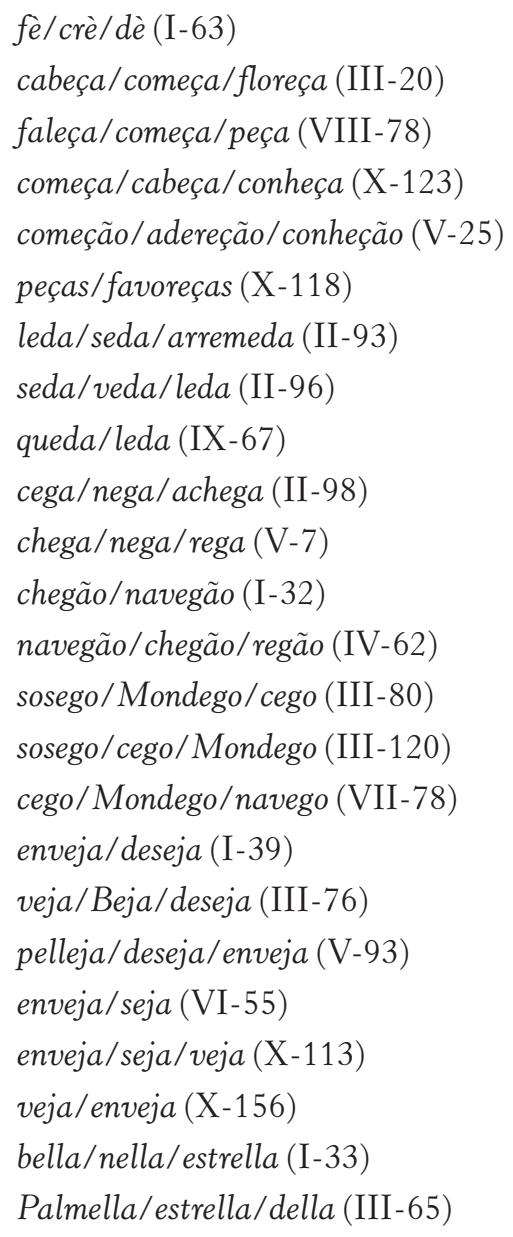


Castella/socorrella ${ }^{7}$ (III-99)

donzella/vencella/della (III-127)

estrella/della/bella (V-14)

Castella/estrella/nella(VI-47)

perdella/della (VI-83)

Castella/nella/estrella (VIII-25)

Estrella/Castella/bella (VIII-29)

della/estrella/donzella (IX-81)

dellas/vellas/estrellas (V-23)

bellas/estrellas (VI-87)

Caravellas/cometellas (X-18)

aquelle/elle/pelle (V-28)

aquelle/Hele/impelle (VI-63)

aquelle/pelle/nelle (IX-23)

velha/aparelha/ovelha (III-131)

aparelha/velha/aconselha (IX-50)

velho/conselho/aparelho (I-82)

velho/aparelho/vermelho (III-75)

conselho/velho/aparelho (IV-76)

velho/espelho (VIII-13)

zelo/amarelo (X-62)

regelos/Vasconcelos (IV-24)

cabellos/amarellos (V-39)

bellos/cabellos (V-55)

bellos/cabellos/amarellos (IX-56)

perde/verde (III-52, V-7)

perdes/verdes/quiserdes (IX-59)

receberes/poderes/quiseres (VI-15)

pareceres/poderes/quiseres (VIII-60)

7 A grafia dos dados corresponde exatamente à que foi empregada na primeira edição (1572) de Os Lusíadas, ou seja, não há adaptações ortográficas. Por isso, a grafia adotada para as formas verbais acompanhadas de clíticos não corresponde à grafia atual, nos dados arrolados acima: socorrella (socorrê-la), vencella (vencê-la), perdella (perdê-la), regelos (regê-los) etc. 


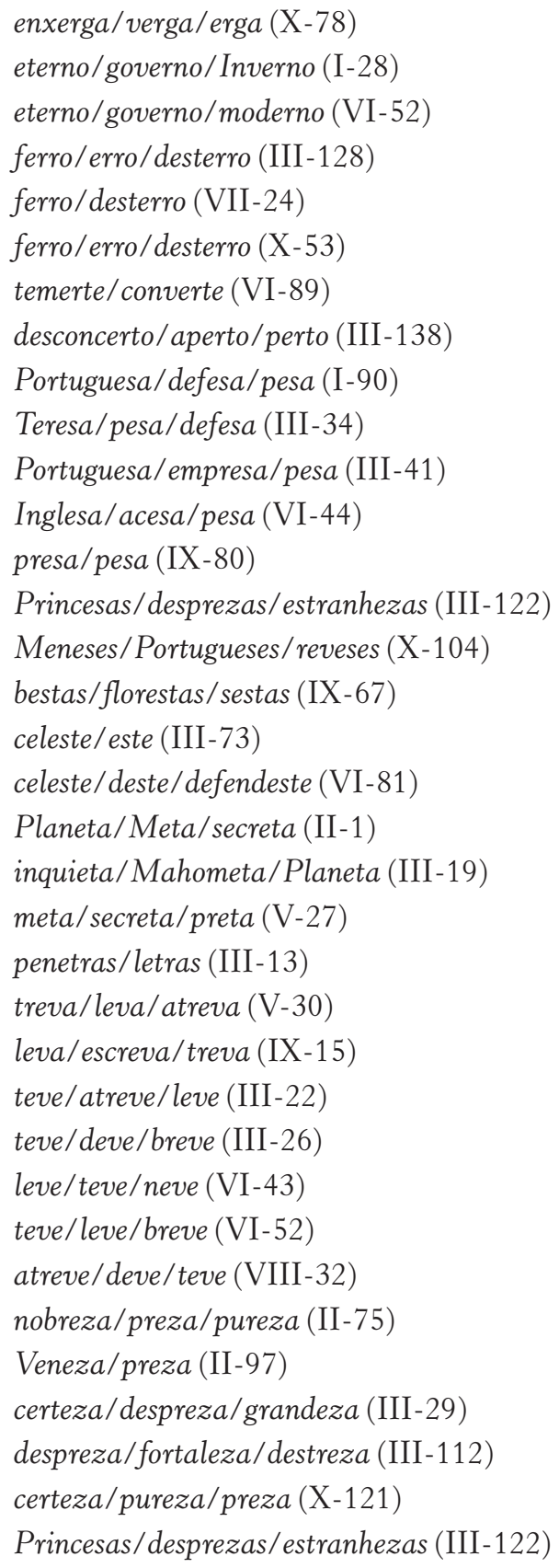




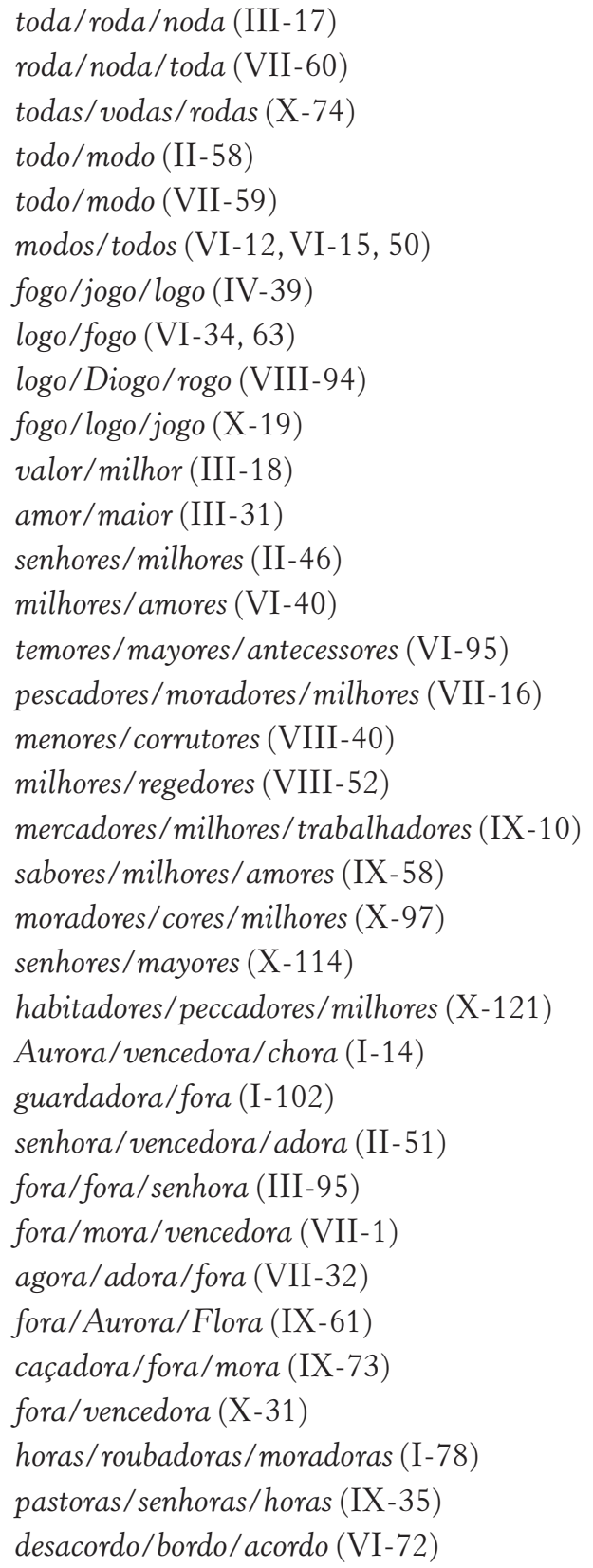




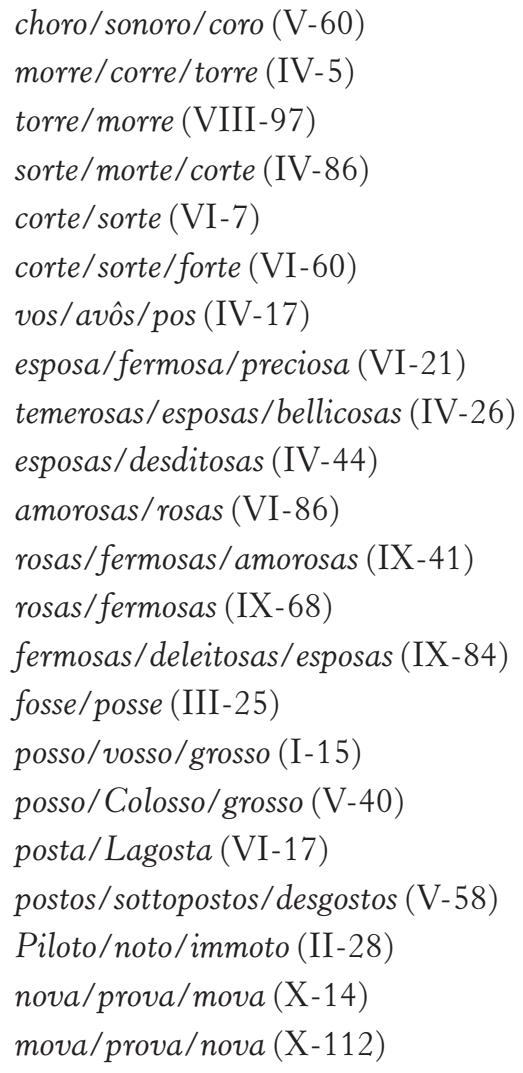

Conforme se pode notar, algumas das rimas arroladas acima também ocorreram nas CSM - e são justamente as que Fonte (2010) procurou justificar por meio da origem histórica de cada termo (ex.: inveja, jogo, fogo, maior, melhor etc.). Merece destaque, entre esses dados, o caso da terminação -osa. Os exemplos arrolados em (21) mostram que, na obra de Camões, os adjetivos terminados em - osa(s), tais como fermosa e preciosa, rimam tanto com o substantivo esposa, como nas CSM, quanto com o substantivo rosa (lat. rŏsa). ${ }^{8}$

8 Todas as informações sobre a origem histórica das palavras, neste trabalho, são baseadas nos dicionários de Corominas (1980-1991), Cunha (2000) e Saraiva (2006). 
Diante dos dados arrolados acima, somos levados a acreditar que, no século XVI, ocorriam as duas pronúncias (com ô e com ó), para a terminação -osa desses adjetivos. Essa variação, registrada nas rimas de Os Lusíadas, estaria denunciando, assim, uma mudança em curso, no português quinhentista, que viria a se consolidar posteriormente.

Conforme já mencionado neste trabalho, o recurso à origem histórica das vogais tônicas explica somente algumas das rimas arroladas em (20) e (21). Além das rimas envolvendo as terminações - eja, -ogo e -or, também registradas nas CSM, a etimologia consegue justificar pouquíssimos casos de rima, nos versos de Camões, como aquele envolvendo a terminação -osso, por exemplo, já que a rima entre posso, vosso e grosso poderia ser justificada a partir da origem histórica da vogal tônica do adjetivo grosso, proveniente do latim grŏssus. Sabendo que ŏ latino originou, no português, uma vogal média aberta (/っ/), na sílaba acentuada, poderíamos admitir a possibilidade de, no século XVI, a vogal média do adjetivo grosso apresentar um timbre vocálico diferente do atual. Outro caso de rima, em Os Lusíadas, que admitiria uma explicação etimológica é o que envolve os vocábulos espelho e velho, já que a origem histórica determina uma vogal tônica aberta tanto para velho, quanto para espelho: větulus e spěcŭlum.

As demais rimas de Os Lusíadas contendo o vocábulo velho, no entanto, correspondem aos casos em que a rima não pode ser justificada por meio do recurso histórico, já que a procedência latina das vogais médias indica fonemas vocálicos diferentes, entre os termos rimantes. Em outras palavras, as rimas velho/conselho/aparelho, velho/aparelho/vermelho e conselho/velho/aparelho não podem ser explicadas com base na etimologia de cada termo porque a origem latina determina, para velho (lat. větulus), uma vogal média aberta $(/ \varepsilon /)$, na sílaba tônica, ao passo que, para os demais termos que compõem os grupos rimantes - conselho (lat. consĭlium), aparelho (lat. apparı̌culāre) e vermelho (lat. vermiculus) - a etimologia estabelece uma vogal média fechada (/e/), na posição acentuada. Para citar mais alguns exemplos entre as rimas envolvendo apenas 
nomes, vale dizer que a origem histórica também determina fonemas vocálicos diferentes para os termos rimantes em aquele (lat.: eccu ùlle) / ele (lat.: ĭlle) / pele (lat.: pěllis) e em modo (lat. mŏdus) / todo (lat. tōtus).

Diante desses dados, parece evidente que o modelo de rima empregado em Os Lusíadas não corresponde ao que observamos nas CSM. Estudiosos (cf. Cunha, 1985; 1991) afirmam que, no século XVI (após Gil Vicente, na verdade), era comum, na poesia portuguesa, rima entre vogal média aberta e fechada. Pode estar baseada nessa afirmação a explicação para as rimas de Camões acima discutidas. Contudo, acreditamos que dizer, simplesmente, que era comum, na época, rima entre vogal média aberta e fechada significa reduzir demais as possibilidades de interpretação que os dados deste trabalho proporcionam. É preciso, antes, traduzir as pistas que esse tipo de rima pode estar revelando sobre as vogais médias da época.

Talvez seja o caso de dizer que, naquele momento da língua, houve uma certa confusão em relação ao timbre das vogais médias portuguesas, o que teria acarretado variação na pronúncia - daí a possibilidade de rima. Pode-se dizer, inclusive, que tal confusão não acontecia, muito provavelmente, no período trovadoresco, a julgar pelas rimas das CSM, que só indicaram uma possível variação na pronúncia da vogal tônica da terminação -ela, em palavras como ela, aquela e donzela.

Um argumento a favor dessa hipótese é o fato de a diferença de timbre entre as vogais médias do português ser sutil e, muitas vezes, frágil, suscetível à variação. Alguns termos, ainda hoje, variam quanto à pronúncia da vogal média tônica, ou seja, ainda não apresentam um único timbre estabelecido (ex.: $f[\varepsilon] c h a \sim f[e] c h a, \operatorname{sap}[e] \sim$ $\operatorname{sap}[\varepsilon], T[e] j o \sim T[\varepsilon] j o, p[o] c ̧ a \sim p[\rho] c ̧ a$ etc. $).{ }^{9}$ Outro dado a ser considerado é o fato de haver, no galego atual, variação na pronúncia da vogal tônica de alguns dos termos referidos neste trabalho: $l[e] d a \sim$

9 Estamos considerando, nesses exemplos, apenas pronúncias referentes ao português do Brasil - variedade culta de São Paulo, precisamente. 


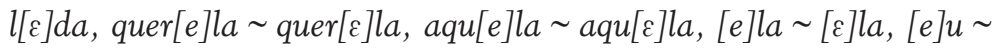
$[\varepsilon] u, m[e] u \sim m[\varepsilon] u, s[e] u \sim s[\varepsilon] u, t[e] u \sim t[\varepsilon] u, f[$ o]go $\sim f[o] g o, x[o] g o$ $\sim x[$ o]go (jogo), $n[$ o]vo $\sim n[o] v o$, son[o]ro $\sim \operatorname{son}[$ ] ]ro (cf. Dicionario de pronuncia da lingua galega). Vale comentar, ainda, o caso de palavras como velho e vermelho, que rimam entre si, na obra épica de Camões. Enquanto no Brasil, há uma clara diferença entre as terminações desses vocábulos, porque apresentam vogais médias distintas, do ponto de vista fonológico $(v / \varepsilon / l h o$ e verm/e/lho), em Portugal, por vezes, essa diferença não é assim tão evidente, em virtude da influência da consoante palatal $(/ K /)$ da sílaba seguinte (veja-se nota 5). Todos esses dados permitem-nos considerar a possibilidade de as rimas de Os Lusíadas não serem, afinal, "imperfeitas".

Além disso, há, no português atual, poucos exemplos de pares mínimos envolvendo os fonemas /e/ e / $\varepsilon /$, assim como /o/ e / / . As rimas apresentadas neste item do trabalho podem estar revelando, inclusive, que o português esteve a um passo de adquirir uma fonologia semelhante à do espanhol, em que a distinção de timbre entre as vogais médias não é fonológica. Não se pode desprezar, nesse caso, o fato de que os falantes de português tinham um contato frequente com a língua castelhana na época.

Outro ponto que merece ser discutido, quando o assunto é a diferença de timbre entre as vogais médias da língua, na posição acentuada, é o caso da flexão verbal do português. Segundo Mateus (2003), na primeira pessoa do singular do presente (indicativo e subjuntivo), ocorre harmonização ${ }^{10}$ entre a vogal média tônica e a vogal temática dos verbos, nas três conjugações (-ar, -er, -ir). De acordo com a autora, a vogal temática, antes de ser suprimida, deixa o seu traço de altura flutuante, que se liga à vogal subespecificada (o que ocorre antes da colocação do acento). Assim, na primeira conjugação, a vogal média fica aberta (levo, leve, moro, more), por

10 De acordo com Xavier e Mateus (1990, p.200), a harmonia vocálica corresponde "ao modo como a articulação de uma vogal é influenciada pelas propriedades de outra(s) vogal(ais) na mesma palavra ou no mesmo grupo de palavras". 
influência da vogal temática $a$; na segunda conjugação, a vogal média é fechada (devo, deva, movo, mova), por influência da vogal temática $e$; e na terceira conjugação, a vogal tônica torna-se alta (firo, fira, durmo, durma), por influência da vogal temática $i$. Há, entretanto, algumas exceções a essa regra: chego, quero, peço e impeço, por exemplo.

No que diz respeito ao abaixamento da vogal média, nas segunda e terceira pessoas do singular, e na terceira pessoa do plural, também no presente do indicativo e subjuntivo, Mateus (2003) explica que, nos casos em que a vogal temática não é suprimida, após a colocação do acento, a vogal média recebe o traço [+baixo] (ex.: levas, moras, deves, moves, feres, dormes). Cabe observar que tal regra só se aplica a vogais que não apresentem o traço [+alto] ( $i$, $u$ ), nem o traço [+baixo] (a), ou seja, deve ser uma vogal média. No caso da presença do traço [+alto], há exceções para a vogal posterior: fugir e subir, por exemplo. ${ }^{11}$

Mateus (2003) mostra que autores como Williams (1975[1938]) e Piel (1944) explicam essa alternância vocálica, nos verbos do português, a partir de analogia e assimilação com a vogal átona final (ou com a semivogal de alguns verbos latinos), mas não mencionam a influência da vogal temática. Para Williams (1975[1938]), nos verbos regulares das segunda e terceira conjugações, com vogal breve no radical latino (ex.: verter, volver, servir, dormir), a diferença de timbre entre a vogal tônica da primeira pessoa do singular e a das demais pessoas (nas formas rizotônicas) do presente do indicativo deve-se à influência da vogal átona final -o, marca de primeira pessoa. Segundo o autor, no português antigo, essa assimilação ainda não ocorria e, portanto, as vogais tônicas eram médias abertas, na segunda conjugação ( $v[\varepsilon] r t o, v[o] l v o)$, e médias fechadas, na terceira conjugação (s[e]rvo, $d[o] r m o$ ), por influência da semivogal latina (sěrvǐo, dŏrmĭo). No que diz respeito ao presente do subjuntivo,

11 Para conhecer outras propostas de análise fonológica à alternância vocálica envolvendo determinadas formas verbais do português, veja-se o trabalho de Battisti e Vieira (2005). 
o autor declara que a vogal média fechada ocorre por analogia às formas do indicativo.

Diante dessas asserções, Mateus (2003) indaga qual seria a explicação para a ocorrência da vogal média aberta em formas que, no latim, não apresentavam uma vogal média breve, mas outras vogais, que originaram, no português, vogais médias fechadas: $d[\varepsilon]$ ve (dēbet), s[0]be (sŭbĭt), t[0]sse (tŭssĭt).

Observando os dados arrolados em (20) e (21), verifica-se que muitas das rimas apontadas envolvem justamente as formas verbais do presente. Entre esses dados, merecem destaque as rimas contendo os verbos pedir e chegar, que representam uma exceção à regra de harmonização vocálica anteriormente referida, conforme acima mencionado. A rima atreve/deve/teve também traz um componente que merece apreço: o verbo dever (lat. dēbēre), mencionado, acima, como um exemplo de que a origem latina não é suficiente para explicar todos os casos de abaixamento vocálico entre os verbos do português atual (ex.: deve, deves etc.). A ocorrência dessas formas verbais, nas rimas de Os Lusíadas, leva-nos a refletir sobre a atuação dos processos de harmonia e abaixamento vocálicos no português antigo. Parece aceitável a ideia de que, no século XVI, essas regras ainda não estivessem totalmente estabelecidas e, em virtude de uma confusão envolvendo a origem histórica dos verbos e a aplicação de processos fonético-fonológicos, fosse comum, entre os falantes da época, uma variação na pronúncia dessas formas verbais do presente. Nossa proposta é a de que, no português falado por Camões e seus contemporâneos, as regras de harmonização e abaixamento estavam começando a atuar na flexão verbal, porque o que prevalecia, até então, era o timbre vocálico correspondente ao étimo latino (ex.: pětěre, plǐcare, dēbēre, escaecer, quaerere). Vale dizer que, em muitos casos, é esse timbre correspondente à origem histórica que permanece no português atual (ex.: peço, peça, chego, chega, quero, deseja etc.), e não o timbre resultante dos processos fonético-fonológicos referidos. Para alguns desses casos (chegar, por exemplo), poderíamos admitir a hipótese de a atuação dos processos fonético-fonológicos terem perdido força, ao longo da história da língua, de modo 
que suas formas do presente (indicativo e subjuntivo) representam, hoje, uma exceção à aplicação das regras de harmonia e abaixamento.

No caso das rimas de Os Lusíadas envolvendo nomes, merece atenção o fato de grande parte dos vocábulos envolvidos terminarem em - $a$ ou $-o$ : vogais tradicionalmente apontadas como gatilho em processos de metafonia, responsáveis pela abertura e fechamento de fonemas vocálicos. Tal razão autoriza-nos a suspeitar da influência dessas vogais na pronúncia da vogal tônica de termos

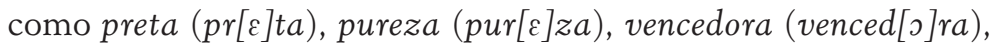
$\operatorname{modo}(m[o] d o)$ etc., no português antigo. Essa hipótese tem respaldo em outros dados - alguns já discutidos neste trabalho, referentes a mudanças de timbre vocálico, por influência, ao que tudo indica, da vogal átona final - a e -o: gloriosa, formosa, essa, promessa, jogo, fogo, senhora, entre outros exemplos. ${ }^{12} \mathrm{Um}$ argumento a favor dessa hipótese é o fato de muitos desses nomes serem pronunciados, no galego atual, com uma vogal média tônica diferente daquela que

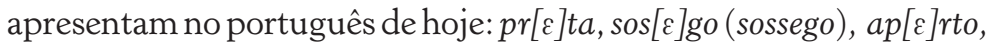

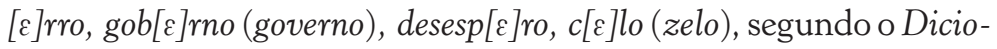
nario de pronuncia da lingua galega. Importa dizer que, caso tivéssemos, no português atual, uma pronúncia como a do galego, para alguns desses termos, não teríamos a seguinte distinção entre nomes

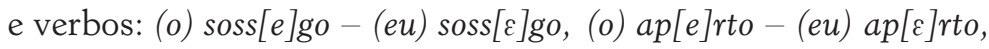
(o) $[e] r r o-(e u)[\varepsilon] r r o,(o)$ gov $[e] r n o-(e u)$ gov $[\varepsilon] r n o,(o)$ desesp $[\varepsilon] r o-$

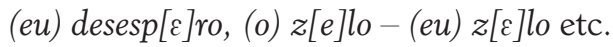

À luz desses fatos, somos levados a acreditar que, no início do português moderno, já atuavam, entre as vogais tônicas da língua, processos fonético-fonológicos de natureza assimilatória tais como

12 Com base em teorias mais recentes da Fonologia, pode-se dizer que o processo de metafonia nominal, proposto pelas gramáticas históricas da língua, é discutível, porque reconhece a influência de uma vogal átona na realização de uma vogal tônica, contrariando, por exemplo, o princípio de Fidelidade Posicional (cf. Beckman, 1997). Contudo, na ausência de uma justicativa mais adequada para a mudança no timbre da vogal tônica dos termos referidos, optamos por não desprezar, no presente estudo, a explicação tradicional baseada no processo de metafonia. 
a harmonia vocálica e a metafonia, por exemplo. As rimas das CSM, analisadas na subseção anterior, sugeriram que, no século XIII, o timbre das vogais médias, na posição acentuada, ainda correspondia à origem latina (ex.: [e]ssa, prom[e]ssa, env[e]ja, ferm[o]sa, glori[o]sa, f[o]go, j[o]go etc.). As rimas de Os Lusíadas, por seu turno, sugerem que, no século XVI, a atuação dos processos assimilatórios referidos passou a interferir na pronúncia das vogais tônicas da época, surgindo, assim, uma variação entre formas etimológicas, de um lado, e formas fonéticas, de outro. No decorrer da história da língua, essa variação foi diminuindo e estabeleceram-se os timbres vocálicos atuais. Em alguns casos, prevaleceu a variante fonéti-

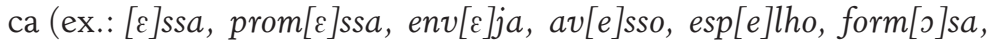
glori[o]sa, senh[o]ra, f[o]go, j[o]go, $n[o] v o)$, em outros, a variante etimológica (ex.: $v[\varepsilon] l h o, l[\jmath] g o, m[\jmath] d o$ ).

Por fim, é interessante acrescentar que, entre tantas rimas possíveis, em Os Lusíadas, a divisão envolvendo a terminação -eu, nas CSM, permanece na obra épica de Camões. Verificamos que, em Os Lusíadas, como nas cantigas afonsinas, verbos de segunda conjugação flexionados na terceira pessoa do singular, no pretérito perfeito do indicativo, não rimam com os vocábulos terminados em -eu. Esses verbos, inclusive, são grafados somente com a terminação -eo (ex.: perdeo, venceo, escondeo) na obra de Camões. Particularmente em relação à terminação -eu, verificamos que ocorre em apenas duas rimas de Os Lusíadas, a saber:

Mais ladrões castigando aa morte deu, Que o vagabundo Alcides, ou Theseu. (Canto III, $137^{\mathrm{a}}$ estrofe)

Nesta remota terra, hum filho teu

Nas armas contra os Turcos serâ claro, Ha de ser dom Christovão o nome seu, Mas contra o fim fatal não ha reparo: 
Ve ca a Costa do mar, onde te deu

Melinde hospicio gasalhoso e caro

O Rapto rio nota, que o romance

Da terra chama Obî, entra em Quilmance.

(Canto X, 96 estrofe)

Vale lembrar que a rima entre a forma verbal deu e pronomes como meu, teu, seu e eu já ocorria nas CSM. O verbo dar, de primeira conjugação, é o único que aparece rimando, nas obras estudadas, com os pronomes referidos, e não rima, portanto, com os verbos de segunda conjugação flexionados na forma correspondente. A propósito, em Os Lusíadas, a forma verbal deu diferencia-se das demais, por ser a única grafada com terminação -eu, e não -eo. Vejamos alguns exemplos de rima envolvendo a terminação -eo nos versos de Camões:

Isto dizendo yrado, e quasi insano,

Sobre a terra Affricana descendeo,

Onde vestindo a forma e gesto humano,

Pera o Prasso sabido se moveo.

E por milhor tercer o astuto engano,

No gesto natural se converteo,

Dum Mouro, em Moçambique conhecido,

Velho, sabio, e co Xeque muy valido.

(Canto I, $77^{\mathrm{a}}$ estrofe)

Desta arte em fim tomada se rendeo,

Aquella que nos tempos ja passados

Aa grande força nunca obedeceo,

Dos frios povos Sciticos ousados:

Cujo poder a tanto se estendeo,

Que o Ibero o vio, e o Tejo amedrontados.

(Canto III, 60 a estrofe) 
Aparta o Sol a negra escuridade,

Removendo o temor ao pensamento:

Assi no Reino forte aconteceo,

Despois que o Rei Fernando falleçeo.

(Canto IV, $1^{\text {a }}$ estrofe)

Cunha (1985; 1991), baseado em demais rimas da época, declara que, no século XVI, a vogal média dos pronomes eu e meu, por exemplo, já não era aberta, como no século XIII. A explicação de Cunha $(1985 ; 1991)$ para não haver rima, ainda no século XVI, entre esses termos (eu, meu, teu, seu, judeu etc.) e os verbos referidos baseia-se na vogal átona final dessas formas verbais: o autor acredita que a nova grafia, com -o átono final (morreo, venceo, viveo), e não mais com - $u$ (morreu, venceu, viveu), adotada na obra de Camões, indica que a pronúncia dessa semivogal não seria a mesma que em eu e meu, por exemplo.

Considerando-se as hipóteses levantadas neste trabalho sobre as rimas de Os Lusíadas e as vogais médias da época, parece apropriada a proposta de Cunha $(1985 ; 1991)$ de que não é a vogal média que está impedindo uma rima entre meu e morreu, por exemplo.

Além disso, vale dizer que, para a terminação -eo(s), também registramos, nos versos de Camões, rima entre vogais médias que, no português atual, apresentam timbres diferentes:

Trouxe o filho de Iapeto do Ceo

$\mathrm{O}$ fogo que ajuntou ao peito humano,

Fogo que o mundo em armas accendeo

Em mortes, em desonras (grande engano)

Quanto milhor nos fora Prometeo, E quanto pera o mundo menos dano, Que a tua estatua Illustre não tivera Fogo de altos desejos, que a movera.

(Canto IV, $103^{\mathrm{a}}$ estrofe) 
Ia a vista pouco e pouco se desterra

Daquelles pátrios montes que ficavão,

Ficava o charo Tejo, e a fresca serra

De Sintra, e nella os olhos se alongavão:

Ficavamos tambem na amada terra

O coração, que as magoas lâ diyxavão,

$\mathrm{E}$ ja despois que toda se escondeo

Não vimos mais em fim que mar e ceo.

(Canto V, $3^{\mathrm{a}}$ estrofe)

E do primeiro Illustre, que a ventura

Com fama alta fizer tocar os Ceos,

Serey eterna e nova sepoltura

Por juizos incognitos de Deos:

Aqui porà da Turca armada dura

Os soberbos e prosperos tropheos,

Comigo de seus danos o ameaça

A destruida Quiloa com Mombaça.

(Canto V, $45^{\mathrm{a}}$ estrofe)

Para Cunha (1985; 1991), no século XVI, a vogal média de Deos também já não era aberta, como no século XIII, e os dados apresentados acima constituem um exemplo claro de que, na época de Camões, era comum rima entre vogais médias abertas e fechadas, fruto da técnica versificatória implantada por Gil Vicente:

Foi, em verdade, o grande dramaturgo português - provavelmente influenciado pelo sistema fonológico do espanhol, que não opõe /e/ a / $/$ / nem /o/ a / / - quem introduziu na versificação portuguesa a liberdade de rima entre vogais tônicas abertas e fechadas, liberdade que se estendia também aos ditongos. (Cunha, 1991, p.923) 
Aceitamos, neste trabalho, a interpretação de Cunha (1985; 1991), com a ressalva de que não basta, simplesmente, afirmar que era comum, na época, dispor em rimas vogais médias abertas e fechadas. O novo esquema rímico, introduzido por Gil Vicente na poesia portuguesa e desconhecido, portanto, dos trovadores, autoriza-nos a considerar a hipótese de haver, no século XVI, uma variação na pronúncia das vogais médias tônicas do português.

Desse modo, o presente estudo vem propor que as rimas de Os Lusíadas, ao contrário do que possam parecer, à luz de dados atuais, não eram imperfeitas na época em que foram empregadas. Se os vocábulos analisados foram dispostos em rima pelo poeta do século XVI, não é recusável a ideia de que havia uma perfeita correspondência entre os fonemas rimantes, em alguma(s) das pronúncias recorrentes no português de então.

\section{Considerações finais}

Diante do que foi apresentado ao longo deste capítulo, pode-se dizer que o presente trabalho, por meio da análise das rimas dos textos poéticos remanescentes dos séculos XIII e XVI, trouxe informações relevantes sobre a pronúncia das vogais médias tônicas do português antigo.

A partir da observação das rimas empregadas nas cantigas medievais religiosas, Fonte (2010) obteve pistas que sugerem uma distinção de timbre, na posição acentuada, entre as vogais médias do PA (fase trovadoresca). As rimas de Os Lusíadas, por seu turno, levam-nos a acreditar que, no início do português moderno, pelo menos, havia variação na pronúncia de determinados termos - e isso foi refletido nas rimas da poesia da época. Em alguns casos, a variação resultou em mudança, ao longo da história da língua. Em outros, todavia, a variação cedeu em favor de pronúncias correspondentes ao étimo latino.

Este trabalho, portanto, vem atestar a importância dos textos poéticos no estudo de propriedades fonéticas de períodos remotos 
da língua, dos quais não se tem qualquer registro oral. Mostramos, ao longo deste capítulo, que determinadas características fônicas do português antigo só podem ser apreendidas por meio da análise das rimas da poesia de antanho. Pode-se dizer, enfim, que as rimas dos textos poéticos antigos são capazes de reproduzir (ou ecoar), de certo modo, as vozes do passado.

\section{Referências bibliográficas}

BATTISTI, E.; VIEIRA, M. J. B. O sistema vocálico do português. In: BISOL, L. Introdução a estudos de fonologia do Português Brasileiro. Porto Alegre: Edipucrs, 1996. p.165-201.

BECKMAN, J. Positional Faithfulness. Doctoral dissertation, University of Massachusetts, Amherst, 1997.

BETTI, M. P. Rimario e Lessico in Rima delle Cantigas de Santa Maria di Alfonso X di Castiglia. Pisa: Pacini Editore, 1997.

CÂMARA JR., J. M. História e estrutura da língua portuguesa. 3 ed. Rio de Janeiro: Padrão, 1979. (1 ed. Brasileira em 1975)

CAMÕES, L. V. de. Os Lusíadas. 1 ed. (1572). Versão digitalizada. In: http://objdigital.bn.br/acervo_digital/div_obrasraras/or633602. pdf. Acesso: 05 nov. 2014.

COROMINAS, J.; PASCUAL, J. Diccionario crítico etimológico castellano e hispánico. Madrid: Gredos, 1980-1991. (vols. I-VI)

COUTINHO, I. L. Pontos de gramática histórica. 6 ed. Rio de Janeiro: Livraria Acadêmica, 1974.

CUNHA, A. G. da. Dicionário etimológico Nova Fronteira da língua portuguesa. 2 ed. Rio de Janeiro: Nova Fronteira, 2000.

CUNHA, C. O valor das finais -eu e -eo na língua portuguesa do século XVI. In: Actes du XVII ${ }^{e}$ Congrès International de Linguistique et de Philologie Romanes (Aix-en-Provence, 29 août-3septembre 1983), vol. III, Aix-en-Provence - Marseille, 1985, p. 272-278.

CUNHA, C. Valor das grafias -eu e -eo na língua portuguesa do século XIII ao século XVI. In: Estudos Portugueses. Homenagem a Luciana Stegagno Picchio. Lisboa, Difel, 1991, p. 913-927.

DICIONARIO de pronuncia da lingua galega. Disponível em: http://ilg. usc.es/pronuncia/?q=\&l=1. Acesso: 05 nov. 2014. 
FONTE, J. S. Rumores da escrita, vestígios do passado: uma interpretação fonológica das vogais do português arcaico por meio da poesia medieval. São Paulo: Cultura Acadêmica, 2010.

LEÃO, A. V. Cantigas de Santa Maria de Afonso X, o Sábio: aspectos culturais e literários. São Paulo: Linear B; Belo Horizonte: Veredas \& Cenários, 2007.

LEITE DE VASCONCELLOS, J. Lições de Filologia Portuguesa. 3.ed. Rio de Janeiro: Livros de Portugal, 1959.

MATEUS, M. H. M. A harmonização vocálica e o abaixamento de vogais nos verbos do português. In.: Língua Portuguesa: estruturas, usos e contrastes. Volume comemorativo dos 25 anos do Centro de Linguística da Universidade do Porto. Porto, 2003.

.; ANDRADE, E. de. The Phonology of Portuguese. Oxford: Oxford University, 2000.

MATTOS E SILVA, R. V. O Português Arcaico: fonologia, morfologia e sintaxe. São Paulo: Contexto, 2006.

MICHAËLIS DE VASCONCELOS, C. Lições de Filologia Portuguesa. Rio de Janeiro: Martins Fontes, 1946.

NUNES, J. J. Compêndio de Gramática Histórica Portuguesa: fonética e morfologia. 6 ed. Lisboa: Livraria Clássica, 1960.

PARKINSON, S. R. As Cantigas de Santa Maria: estado das cuestións textuais. Anuario de estudios literarios galegos, Vigo, p.179-205, 1998.

PIEL, J. M. A flexão verbal do português: estudo de morfologia histórica. Biblos, n. 20, p.395-404, 1944.

RAMOS, M. A. Nota Lingüística; Critérios de edição; Normas de transcrição. In: GONÇALVES, E.; RAMOS, M. A. A lírica galego-portuguesa (textos escolhidos). 2 ed. Lisboa: Editorial Comunicação, 1985. p. 81-127.

SARAIVA, F. R. dos S. Novíssimo Dicionário Latino-Português: etimológico, prosódico, histórico, geográfico, mitológico, biográfico, etc. 12 ed. Belo Horizonte: Livraria Garnier, 2006.

SILVA NETO, S. da. História da Língua Portuguesa. Rio de Janeiro: Livros de Portugal, 1952.

SOUZA, J. B. P. E. Rimário de Os Lusíadas. Rio de Janeiro: Edições Pedagógicas, 1948.

SOUZA, N. de. Um estudo da ortografia da obra Os Lusíadas (1572) de Luís de Camões. Campinas, 2009. Tese (Doutorado em Linguística) IEL/UNICAMP, Campinas, 2009. 
WILliAMS, E. B. Do Latim ao Português: fonologia e morfologia histórica da língua portuguesa. 3 ed. Rio de Janeiro: Tempo Brasileiro, 1975. (1 ed. em 1938)

XAVIER, M. F.; MATEUS, M. H. M. (Org.). Dicionário de termos lingüísticos. Lisboa: Cosmos, 1990. v. 1. 


\section{7 \\ ANÁlisE dA ATRIBUIÇÃO DO ACENTO LEXICAL NO PORTUGUÊS ARCAICO: UMA ABORDAGEM POR MEIO DA MÚSICA E DO TEXTO DE CANTIGAS TROVADORESCAS}

Daniel Soares da Costa ${ }^{1}$

\section{Introdução}

Neste capítulo, apresentamos a proposta metodológica para coleta de dados relativos à prosódia de línguas mortas - ou de períodos passados de línguas vivas das quais não existem mais falantes - elaborada por Costa (2010a) em sua tese de doutorado. Trata-se de uma metodologia inovadora que trabalha com a articulação entre a música e o texto de cantigas trovadorescas (textos poéticos musicados) como instrumento auxiliar para a coleta de dados relativos à atribuição do acento lexical nas palavras. Apresentaremos o funcionamento dessa metodologia, bem como os resultados alcançados na pesquisa que a desenvolveu.

A língua objeto de análise da atribuição do acento lexical é o português arcaico (doravante PA) e o arcabouço teórico utilizado é a Teoria Métrica, na versão de grades parentetizadas de Hayes (1995).

A metodologia aqui apresentada baseia-se na observação de três instâncias: a observação das proeminências musicais nas partitu-

1 Professor da Faculdade de Ciências e Letras da Unesp, campus de Araraquara. 
ras que acompanham textos poéticos musicados; a observação das proeminências linguísticas dos textos; e a observação da estrutura métrica dos poemas que constituem o corpus de análise. Portanto, sua aplicação depende da existência de textos poéticos musicados escritos na língua que se deseja analisar.

Trabalhos nesse sentido, que foram elaborados nos últimos anos, mostraram que uma metodologia envolvendo música e linguística pode trazer muitas informações pertinentes à análise de fenômenos prosódicos de línguas mortas.

Em relação ao PA, podemos citar os trabalhos de Massini-Cagliari (2008a), que conclui que uma análise em paralelo da notação musical e do texto poético de cantigas trovadorescas pode constituir um instrumento auxiliar para a análise do acento e do ritmo do PA; Massini-Cagliari (2008b), que analisa fenômenos como a paragoge e o ritmo na Cantiga de Santa Maria (doravante CSM) 100, sob a mesma perspectiva metodológica que descreveremos aqui; Massini-Cagliari (2008c), em que temos a comparação do ritmo das cantigas religiosas, visto pela análise da CSM 70, com dois exemplares de cantigas profanas (uma cantiga de amigo e uma cantiga de amor) que sobreviveram com sua notação musical; e Massini-Cagliari (2008d), em que a autora faz considerações sobre a paragoge, a silabação, o ritmo, o status prosódico de clíticos e a existência de palavras proparoxítonas em PA por meio da análise da estrutura musical e linguística de algumas CSM.

Além desses trabalhos, temos os trabalhos de Costa (2007), ${ }^{2} \mathrm{em}$ que, por meio da análise de cinco CSM, nas suas versões transcritas para a notação musical atual, feitas por Ferreira (1986), o autor observa que o tempo mais forte dos compassos musicais marca a sílaba tônica da palavra, no texto do poema, em aproximadamente oitenta porcento dos casos analisados naquele corpus; Costa (2008),

2 Trabalho apresentado em forma de comunicação no $55^{\circ}$ Seminário do GEL, com o título "Da notação musical às proeminências da fala: uma proposta metodológica para o estudo do ritmo linguístico das Cantigas de Santa Maria de Afonso X", no ano de 2007. 
em que o autor também trata de questões de silabação envolvendo a distinção de ditongos e hiatos (inclusive em casos de vogais idênticas), além de casos de ocorrência de acentos secundários em palavras do PA. Em Costa (2009), temos a análise das dez primeiras CSM, em que foi feita uma breve descrição dos procedimentos metodológicos adotados para a coleta de dados com a nova metodologia que confronta as proeminências musicais e linguísticas; já em Costa (2010b), o autor faz um estudo sobre o acento secundário e a tonicidade dos monossílabos em PA por meio da música e da métrica das CSM.

\section{Corpus}

O corpus utilizado por Costa (2010a) para a análise da atribuição do acento no PA constitui-se de um recorte das cem primeiras Cantigas de Santa Maria (CSM), tomadas a partir das suas versões transcritas por Anglés (1943) para a notação musical atual, uma vez que as partituras originais não apresentam a divisão dos compassos musicais.

As CSM formam um conjunto de 420 cantigas, cuja autoria é atribuída a Afonso X, o Rei Sábio de Leão e Castela, feitas com o intuito de louvar a Virgem Maria, com textos poéticos em galego- português. Trata-se de um conjunto de cantigas trovadorescas religiosas, representativo do português no período do século XII até meados do século XIV; um monumento histórico-literário do período medieval riquíssimo para o estudo das áreas da poesia, da música e da pintura, constituindo fontes importantíssimas para a história da métrica, do galego-português antigo, da música, da arte, da religião, enfim, da cultura geral daquela época (Parkinson, 1998).

O corpus constitui-se, portanto, de textos poéticos rigorosamente metrificados e musicados, representativos do período medieval do português, permitindo a observação de proeminências nos dois níveis, o musical e o linguístico. 


\section{Metodologia}

A metodologia utilizada fundamenta-se na observação de três pontos: a música das cantigas, no sentido de observar o tempo mais forte de cada compasso musical, isto é, o primeiro tempo do compasso, mais especificamente, a primeira nota; o texto dos poemas, no sentido de observar qual sílaba das palavras está anexada à nota musical mais proeminente; e a métrica da cantiga, que ajuda a solucionar dúvidas em relação à separação das sílabas na hora de se anexar as demais estrofes da cantiga à pauta musical, uma vez que esta é apresentada apenas no refrão e na primeira estrofe, subentendendo-se que as demais estrofes seguem a mesma linha melódica.

Partimos da ideia de que a nota mais proeminente do compasso musical coincide geralmente com a sílaba mais proeminente das palavras no nível textual e que as não coincidências entre as proeminências nos dois níveis se devem a fatores de outra ordem, tais como prolongamentos de notas musicais.

O corpus direto analisado constitui-se de edições mais atualizadas das CSM, mais especificamente, a de Mettmann (1986) - na qual nos baseamos para o texto dos poemas - e a de Anglés (1943), que contém a transcrição da notação musical medieval para a notação musical atual, uma vez que a partitura medieval não apresenta visivelmente a divisão dos compassos musicais. A seguir mostramos, na Figura 1, um trecho da CSM 10, que apresenta a notação musical original, medieval. Em seguida, na Figura 2, apresentamos a mesma cantiga na versão de Anglés (1943), com a notação musical atual.

A partitura musical das cantigas vem anexada ao refrão e à primeira estrofe apenas, já que, por obedecerem a uma métrica composicional bastante rígida, não é necessária a repetição da música em cada estrofe, pois todas as estrofes serão cantadas com a mesma melodia que é indicada na primeira estrofe.

A anexação das palavras à melodia foi feita, num primeiro momento, por Anglés (1943) e, quando anexamos os demais versos de cada cantiga à sua respectiva melodia, obedecemos à divisão silábica das palavras determinada na edição em questão. 
Figura 1 - Trecho da Cantiga de Santa Maria n ${ }^{\circ} \mathrm{X}$ - Rosa das rosas... - Fac-símile $\mathrm{To}^{3}$

$10 \cdot-$

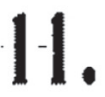

CANTIGA $\mathrm{X}$, fol. $20 \mathrm{v}$.

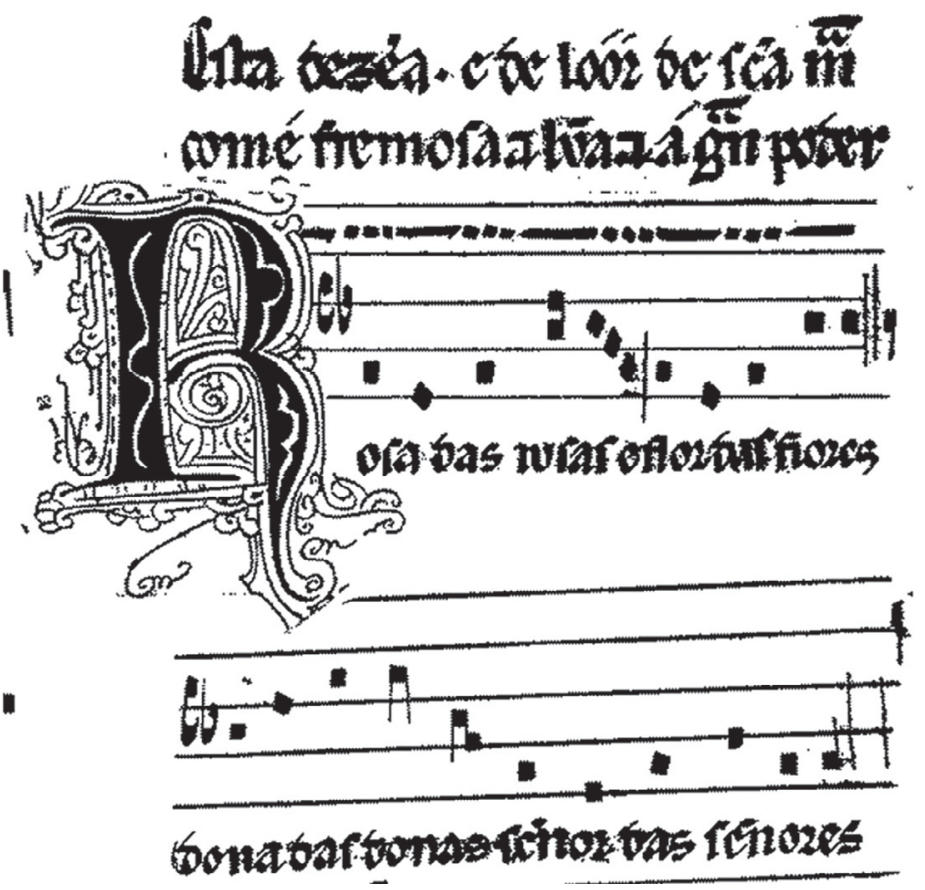

3 Disponível em: <http://www.pbm.com/ lindahl/cantigas/facsimiles/To/ bob010small.gif>. Acesso em: 13 ago. 2013. 
Figura 2 - Transcrição da CSM 10 (Anglés, 1943, p.18, "parte musical”) 18

Esta é de loar de Santa Maria, com'é fremosa

et bõa, et à gran poder.

$$
\begin{array}{ll||c|c|cc}
A^{9} & A^{10} & b^{10} & b^{10} & b^{10} & a^{10} \\
\propto & \beta & \gamma & \gamma & \delta & \beta
\end{array} \mid
$$
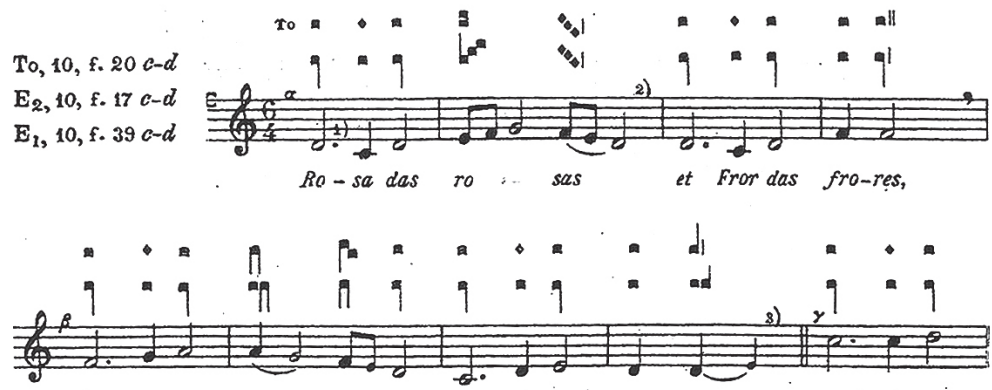

Do - na das do - nas, se - nnor das se - nno-res. Ro-sa de

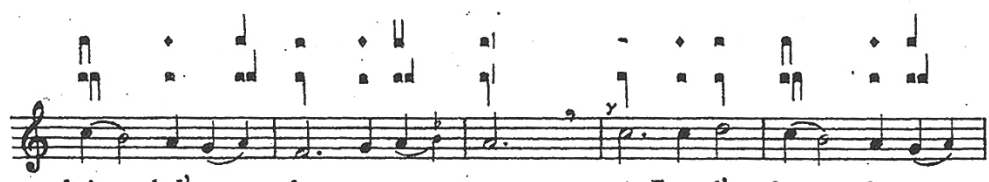

bel - dad'e de pa-re - cer et Fror d'a - le - gri - a
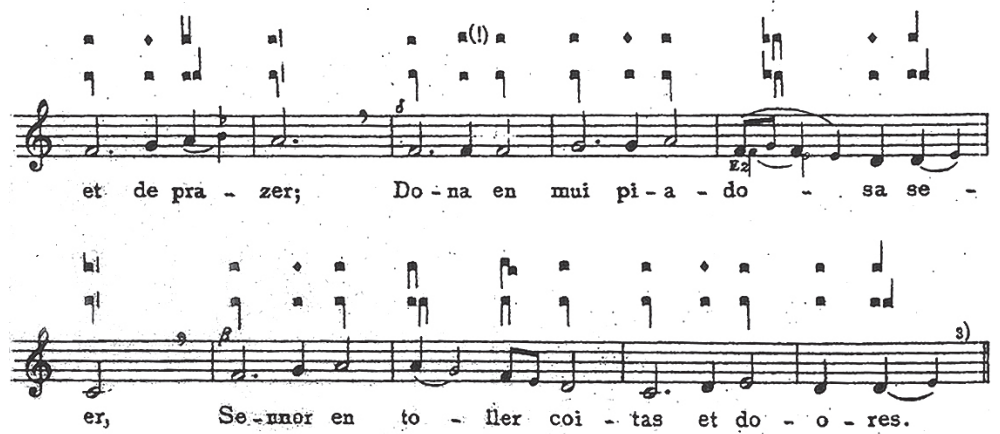

1) To als superior. 2) to 30 To 
Feita a anexação de todos os versos da cantiga à melodia da partitura, partimos para a marcação dos tipos de sílaba que aparecem na posição de proeminência musical; para isso atribuímos a cada tipo de sílaba uma marca diferente, para facilitar a visualização da relação de proeminência entre notas e sílabas. Para a coincidência da proeminência musical com uma sílaba tônica de palavras com mais de uma sílaba, optou-se por marcar a sílaba com negrito; para a coincidência com monossílabos tônicos, foram utilizadas aspas; para átonos, optou-se por colocar um asterisco antecedendo o monossílabo; para a coincidência com sílabas pretônicas, foi utilizada a forma sublinhada; e, por fim, as postônicas finais foram marcadas em itálico.

Abaixo apresentamos um exemplo de como fica a ficha de análise depois de anexados todos os versos à melodia da partitura. Nesse exemplo, temos, em cada linha abaixo da linha partitura, a parte de cada estrofe da cantiga referente ao trecho abrangido pela melodia da primeira linha da partitura da versão transcrita por Anglés (1943).

(1)

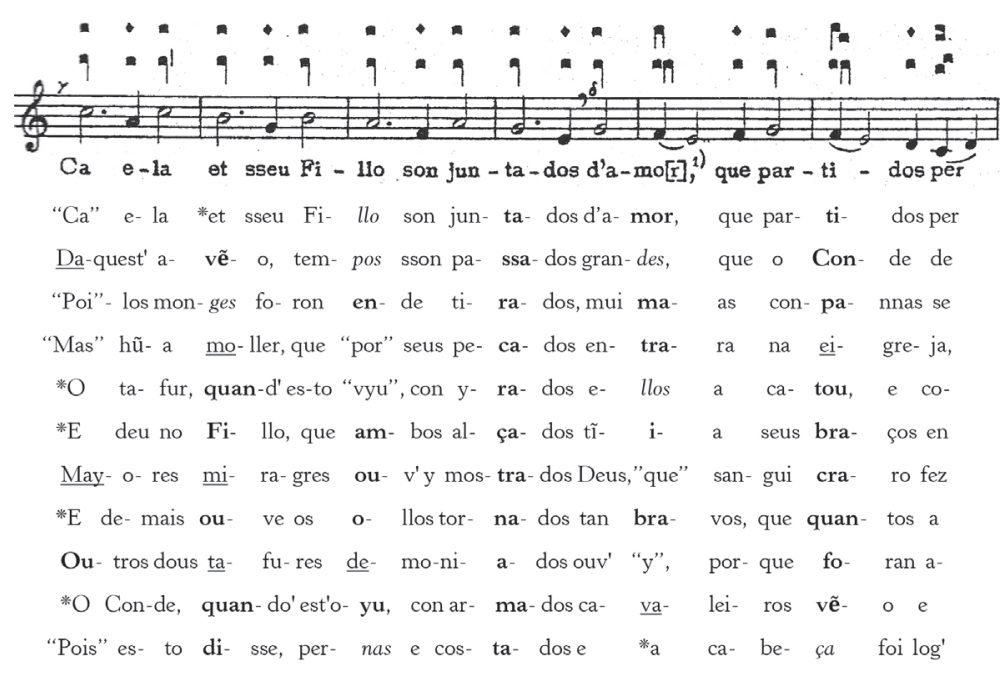


Para cada uma das cem primeiras CSM foi feita uma ficha de análise com a distribuição como a descrita acima. Depois de elaborada a ficha de análise, distribuídas todas as palavras dos versos junto com a melodia que as acompanha e marcadas as sílabas de acordo com o tipo de pauta acentual que coincide com a proeminência musical, partiu-se para a contagem dos tipos de coincidências entre as proeminências musicais e linguísticas, cujos resultados apresentaremos a seguir.

\section{Levantamento de dados}

Na Tabela 1, logo abaixo, apresentamos a quantificação geral relativa às coincidências entre proeminências musicais e linguísticas observadas na análise das cem primeiras CSM através da metodologia apresentada no item anterior.

Tabela 1 - Quantificação geral de coincidências entre proeminências musicais e linguísticas

\begin{tabular}{l|c|c}
\hline Coincidências com tônica & 12997 & $39,76 \%$ \\
\hline Coincidências com monossílabo tônico & 7703 & $23,56 \%$ \\
\hline Coincidências com monossílabo átono & 2531 & $7,74 \%$ \\
\hline Coincidências com pretônica & 4221 & $12,91 \%$ \\
\hline Coincidências com postônica final & 5189 & $15,87 \%$ \\
\hline Coincidências com postônica não final & 44 & $0,13 \%$ \\
\hline Total de proeminências & 32685 & $100 \%$ \\
\hline
\end{tabular}

Vale notar que a quantificação geral dessas coincidências também foi dividida de acordo com a pauta acentual linguística (tônica, pretônica, postônica, monossílabo átono e monossílabo tônico) da sílaba que aparece em posição de proeminência musical, estabelecendo-se os seus respectivos percentuais em relação ao total de coincidências observadas na análise dos dois níveis, o musical e o linguístico. Os dados coletados referentes à análise das cem primeiras CSM nos forneceram uma amostra de mais de 32 mil coincidências entre proeminências musicais e sílabas textuais. 
Observando a tabela acima, chamamos a atenção para o total de coincidências entre a proeminência musical e sílabas tônicas de palavras polissilábicas, num percentual de 39,76\%. Se somarmos este percentual ao percentual de coincidências de proeminências musicais com monossílabos tônicos, temos um total de 63,32\%, o que corrobora a nossa afirmação, feita anteriormente, de que a proeminência musical marca, na maioria dos casos, uma sílaba tônica no nível linguístico.

Também fizemos a contagem de todas as palavras que apareceram no corpus, seja em posição de proeminência musical ou fora dela, o que gerou a Tabela 2, apresentada a seguir.

Tabela 2 - Palavras de acordo com a pauta acentual linguística

\begin{tabular}{l|c|c}
\hline Oxítonas & 4733 & $12,44 \%$ \\
\hline Paroxítonas & 14539 & $38,24 \%$ \\
\hline Proparoxítonas & 113 & $0,29 \%$ \\
\hline Monossílabos tônicos & 12846 & $33,78 \%$ \\
\hline Monossílabos átonos & 5787 & $15,22 \%$ \\
\hline Total & 38018 & $100 \%$ \\
\hline
\end{tabular}

Podemos notar, pela tabela acima, que as pautas acentuais mais recorrentes são de paroxítonas e monossílabos tônicos que, somados, representam 72,02\% do corpus. Além disso, o número de palavras proparoxítonas é muito reduzido em relação às demais pautas acentuais, representando apenas $0,29 \%$ do total, o que, no entanto, não diminui a importância dessa pauta acentual em relação à sua representatividade dentro do corpus, já que, para alguns estudiosos, ainda havia dúvidas sobre a existência da pauta proparoxítona no PA.

\section{Apresentação dos resultados}

Como dissemos anteriormente, o objetivo deste capítulo, além demonstrar a eficácia de uma metodologia que envolva a Música e 
a Linguística na busca de pistas sobre a prosódia de línguas mortas, é divulgar, de maneira resumida, os resultados da tese de doutorado A interface música e linguística como instrumental metodológico para o estudo da prosódia do português arcaico, de Costa (2010a). O modelo teórico utilizado na análise dos dados levantados é Teoria Métrica, na versão de grades parentetizadas de Hayes (1995).

Tomando a Tabela 2, podemos observar que a pauta prosódica com maior número no corpus analisado é a pauta paroxítona, o que sugere, como pé canônico do PA, o troqueu, ou seja, um pé constituído por uma sílaba forte seguida por uma fraca (x .). A esta conclusão também chegaram Massini-Cagliari (1995; 1999) e Costa (2006), devido à grande quantidade de paroxítonas encontradas nas suas respectivas pesquisas.

A atribuição do acento lexical no PA se dá da direta para a esquerda, não iterativamente, e é sensível ao peso silábico da última sílaba da palavra, o que indica, dessa forma, o troqueu moraico como o pé básico dessa língua.

Em relação à influência do peso silábico na atribuição do acento lexical nessa língua, podemos perceber esse fenômeno, comparando palavras paroxítonas com oxítonas conforme o que nos mostra o exemplo (02) a seguir.

$\begin{array}{rrrr}(\mathrm{x} .) & (\mathrm{x}) & (\mathrm{x}) & (\mathrm{x}) \\ \text { an.ti.go } & \text { a.ber.ta } & \text { pe.ca.dor } & \text { in.fer.nal } \\ - & -{ }_{-} & & -\end{array}$

Por meio desse exemplo, podemos verificar que, quando a palavra termina em duas sílabas breves, o acento cai sobre a penúltima sílaba, o que também ocorrerá se a palavra terminar em uma sílaba longa seguida de uma breve; nestes casos, temos palavras paroxítonas. No entanto, se houver uma sílaba pesada (travada por consoante, desde que essa consoante não represente flexão de número) na última sílaba da palavra, esta atrairá o acento para si, 
independentemente de a penúltima sílaba ser longa ou breve, tornando a palavra oxítona. Isso comprova que o PA é sensível ao peso da última sílaba da palavra na construção dos pés.

Uma das contribuições mais importantes deste trabalho diz respeito à possibilidade de análise da pauta proparoxítona, fato inédito nas pesquisas até então. Foram muito poucas palavras encontradas, um total de 113 palavras, o qual, se descontarmos as repetições e mais duas palavras que são originárias do latim (Domini e Dominum), passa a 34 palavras apenas.

Massini-Cagliari (1999, p.131) diz, em relação à análise do acento no português brasileiro, que a maneira mais ortodoxa, dentro da teoria, de adequar as palavras proparoxítonas ao padrão acentual das outras palavras dessa língua é lançar mão do conceito de extrametricidade ou noções próximas.

Analisando a bibliografia existente sobre o assunto, percebemos uma grande diversidade na maneira como os estudiosos abordam a questão das proparoxítonas. Bisol (1992), em relação ao português brasileiro, considera a última sílaba de palavras proparoxítonas como extramétrica; outros autores, como D'Andrade e Laks (1991), Alvarenga (1993), Duarte (1977) e Maia (1981), em relação à análise de palavras proparoxítonas, aludem a sufixos que repelem o acento, tais como -ico, -voro, -fero, por exemplo, ou fazem referência a sequências que não são acentuáveis, tais como -ic e -im-, considerando não acentuáveis as vogais da penúltima sílaba da palavra. Wetzels (1992) diz que essas palavras estão sujeitas a um tipo de neutralização chamada de abaixamento datílico, a qual é aplicada a palavras em cuja posição tônica a vogal é média e sofre abaixamento, tornando-se média-baixa, como em amul[e]to/amul[E]tico, formando um pé ternário excepcional nesses casos.

A solução que achamos mais adequada nesses casos, levando em consideração os dados que temos, é a de Massini-Cagliari (1999, p.134) para o português brasileiro, a qual transcrevemos abaixo:

Em relação a essas palavras, a solução aqui sugerida é que, assim como as derivadas, elas são marcadas no léxico com uma 
instrução para a formação de pés datílicos, não por motivos da presença de um sufixo acento-repelente (já que isso não ocorre), mas individualmente. Assim sendo, nesses casos, não é mais o sufixo que recebe a marca no léxico, mas o próprio item lexical. Desta maneira, o acento é atribuído a essas palavras ainda no primeiro estrato do léxico e, na passagem pelo segundo, a regra default de acentuação não pode ser mais aplicada.

Não podemos deixar de ressaltar o caráter excepcional que envolve as palavras proparoxítonas. O número extremamente pequeno de palavras desse tipo encontradas no corpus utilizado nesta pesquisa, o qual é bem extenso, comprova a excepcionalidade desses casos. Afinal, são apenas 113 palavras proparoxítonas em meio a um corpus constituído de um total de 38018 palavras. Se descontarmos as repetições, teremos apenas 34 palavras proparoxítonas.

Portanto, podemos afirmar que, no PA, as proparoxítonas também são marcadas no léxico com uma instrução para a formação de pés datílicos, a qual é atribuída no primeiro estrato, sendo que, na sua passagem pelo segundo estrato, a regra de acentuação não pode mais ser aplicada. Dessa forma, constitui-se uma palavra excepcionalmente com um pé datílico.

Em relação às palavras monossilábicas, podemos dizer que há, no PA, monossílabos pesados, constituídos de sílaba travada, tais como bel, cruz, Deus, mal etc.; monossílabos que não são constituídos de sílaba travada, mas que são comprovadamente tônicos (de acordo com a afirmação de estudiosos medievalistas e a análise do percentual de incidência de proeminências musicais, sobre tais formas, que confirma a tonicidade das mesmas - cf. Tabela 1), tais como ca, que, si, u, entre outras; e, por fim, monossílabos leves, sem travamento silábico ou travados por elemento representativo de flexão, o que não os torna pesados, tais como de, dos, la, las, te, nos etc.

Em relação à aplicação da teoria, podemos dizer que os monossílabos considerados pesados constituem, sozinhos, um pé, como podemos ver na representação feita no exemplo (03). 
mal

Já no caso dos monossílabos leves, vimos que, apesar de haver uma tendência maior para que essas palavras sejam consideradas átonas, uma vez que, na maior parte dos casos, tais palavras apareceram mais fora da posição de proeminência musical do que nela, eles podem assumir proeminência no PA, dependendo do contexto. Isso pode ser considerado um indício de sua relativa independência prosódica, aproximando nossas conclusões do apontamento feito por Bisol (1996, p.251) em relação aos mesmos casos no português brasileiro.

Portanto, com relação aos monossílabos leves no PA, podemos dizer que, no caso da sua ocorrência, faz-se necessária a constituição de pés degenerados, que são permitidos, no PA, quando nenhum pé canônico puder ser construído.

Sendo assim, podemos dizer que o PA tem uma proibição fraca em relação à ocorrência de pés degenerados. Isso já tinha sido constatado anteriormente em Massini-Cagliari (1999, p.170) e Costa (2006, p.105).

$$
\text { (x) }
$$

de

Outra possibilidade de análise inédita proporcionada pela metodologia que apresentamos diz respeito à análise do acento secundário no PA.

Para encontrarmos elementos que nos permitam fazer considerações a respeito da ocorrência de acentos secundários no PA, devemos observar a relação entre as proeminências musicais e as sílabas pretônicas das palavras encontradas. 
Collischonn (1994), tratando do acento secundário em português, percebe que a porção postônica da palavra é irrelevante para a análise do acento secundário, considerando apenas a porção da palavra que vai do acento primário para a esquerda, analisando, assim, a ocorrência de acento em sílabas pretônicas em relação ao acento primário. Essa postura também pode ser adotada na análise do acento secundário em PA, uma vez que as coincidências entre proeminências musicais e sílabas postônicas, além de representarem um percentual baixo em relação às coincidências entre proeminências musicais e sílabas tônicas, são, na maioria dos casos, justificadas por prolongamentos de sílabas condicionados pela música.

De uma maneira geral, verifica-se que os acentos secundários ocorrem em intervalos regulares no PA, apresentando um padrão preferencialmente binário (97,5\% dos casos), isto é, a cada segunda sílaba, conforme podemos observar na Tabela 3, de um total de 1522 palavras em que foi possível observar a ocorrência do acento secundário, apenas 37 ocorrem com um intervalo maior do que uma sílaba entre o acento primário e o acento secundário. Também foi encontrado apenas um possível caso de palavra com um intervalo de três sílabas entre o acento primário e o acento secundário, o qual discutiremos mais adiante.

Tabela 3 - Acento secundário no PA

\begin{tabular}{l|c|c}
\hline Com alternância binária & 1484 & $97,50 \%$ \\
\hline Com alternância ternária & 37 & $2,43 \%$ \\
\hline Com alternância quaternária & 1 & $0,06 \%$ \\
\hline Total & 1522 & $100 \%$ \\
\hline
\end{tabular}

Uma constatação desse tipo também foi feita por Abaurre e Svartman (2008) em relação ao português brasileiro, levando em consideração a análise acústica e processos fonológicos que interferem na atribuição do acento secundário, tais como processos de sândi vocálico, redução ou deleção de vogal. As autoras constata- 
ram que, em $86 \%$ dos casos analisados no corpus utilizado por elas, o padrão rítmico que se apresentou foi binário, mais especificamente pés troqueus; o restante constitui $6 \%$ de dátilos, $5 \%$ de pés mistos (troqueus e dátilos), e, em $3 \%$ dos casos, não foi possível verificar a ocorrência do acento secundário.

Em relação ao PA, podemos ver a ocorrência de acento secundário por meio do exemplo (05), com uma pequena amostra de palavras, e pelo exemplo (06), que mostra diversas palavras, aparecendo com sua respectiva pauta musical, por meio da qual podemos verificar a ocorrência dos acentos secundários nas suas sílabas pretônicas.

a.ju.dar; a.pou.sen.tar; Ma.da.le.na; al. $\underline{\text { ber.ga.ri. } . a^{4}}$

(06) CSM 1

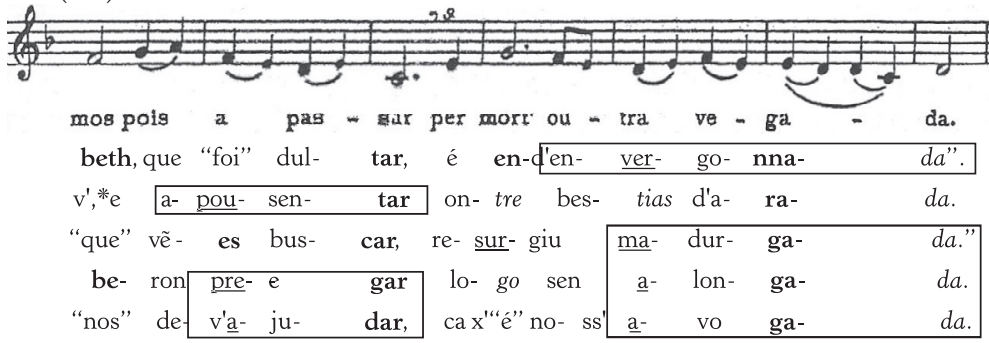

Podemos perceber que há, no PA, três padrões para a atribuição do acento secundário, dependendo do número de sílabas pretônicas existentes nas palavras. $\mathrm{O}$ primeiro padrão diz respeito a palavras que possuem um número par de sílabas pretônicas, nas quais o acento secundário ocorre na primeira sílaba da palavra e a cada segunda sílaba à direita desta, conforme o que está no exemplo (07).

4 O negrito marca a coincidência entre uma proeminência musical e a sílaba tônica da palavra (acento primário); o sublinhado marca a coincidência entre uma proeminência musical e uma sílaba pretônica da palavra (acento secundário). 
(07)

a.ju.dar; de.mos.trar; desaconsella $d a^{5}$

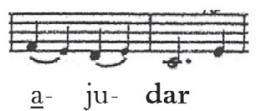

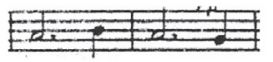

de- mos-trar

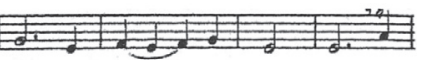

de- sa- $^{\text {con- }}{ }^{-}$se- lla- $d a$

Já em palavras que possuem um número ímpar de sílabas pretônicas, encontramos dois padrões possíveis. No primeiro, o acento secundário ocorre na segunda sílaba da palavra e a cada segunda sílaba à direita desta. Vejamos o exemplo (08) a seguir.

a.pou.sen.tar; en.san.de.ceu
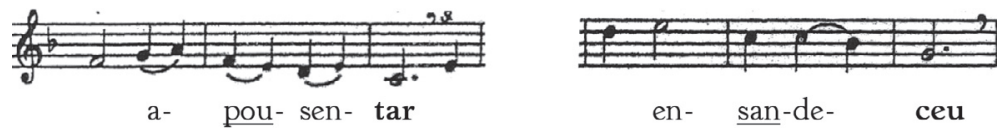

No segundo, o acento secundário ocorre na primeira sílaba da palavra e há um intervalo de duas sílabas até o acento primário, saindo do padrão binário geral, conforme o que podemos ver no exemplo (09).

a.vo.rre.cer; Em.pe.ra.dor; 昏.le.ce.rán

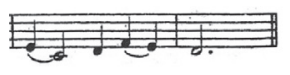

a- vo-rre- cer

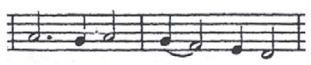

Em-pe-ra- dor

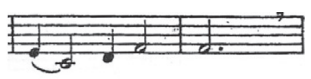

fa- le-ce- rán

Observamos a ocorrência de um terceiro padrão para o acento secundário, o qual apareceu em um caso isolado. Trata-se da palavra malaventurados, na CSM 38, cuja silabação e relação de proeminências linguísticas e musicais apontam para um padrão em que o

5 O itálico marca a coincidência entre uma proeminência musical e a sílaba postônica final da palavra. 
acento secundário ocorre na primeira sílaba e tem-se um intervalo de três sílabas entre este e o acento primário, conforme podemos observar no exemplo (10).

ma.la.ven.tu.ra.dos

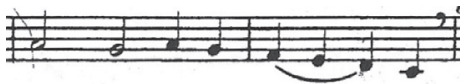

ma- la-ven-tu- ra- dos

No entanto, podemos observar que, no caso de malaventurados, trata-se de uma palavra composta de um monossílabo tônico ( mal) e uma palavra paroxítona com três sílabas pretônicas (aventurados) e, como tal, mantém os acentos primários de cada membro (Collischonn, 1994, p.50).

$$
\text { "mal" + a.ven.tu.ra.dos }
$$

\section{Conclusão}

Por meio do que foi apresentado, concluímos que a ferramenta metodológica desenvolvida na tese de Costa (2010a) e apresentada aqui mostrou-se bastante eficaz na busca de pistas para a análise da prosódia de línguas que não possuem mais falantes, porém possuem registros poético-musicais que podem nos fornecer dados linguísticos.

Os dados coletados mostraram-se bastante confiáveis e relevantes para a análise da atribuição do acento no PA, possibilitando discussões de hipóteses levantadas por trabalhos anteriores e apresentando hipóteses inéditas sobre casos de palavras ainda não contemplados dentro do arcabouço teórico adotado.

Dessa forma, podemos afirmar que, além de demonstrar a eficácia de uma metodologia inovadora dentro da área dos estudos 
fonológicos relacionados à prosódia de línguas mortas, este trabalho contribui significativamente para os estudos prosódicos do PA, uma vez que apresenta casos de palavras inéditos em relação às pesquisas feitas até então, além da análise da pauta proparoxítona e do fenômeno linguístico do acento secundário dentro da Teoria Métrica.

É mais um passo dado em direção à descrição do componente fonológico do PA, além de representar uma inovação metodológica, contribuindo para a melhor compreensão desse período da língua portuguesa e da história de nosso idioma de maneira geral.

\section{Referências bibliográficas}

ABAURRE, M. B. M; SVATRMAN, F. R. F. Secundary stress, vowel redution and rhythmic implementation in Brazilian Portuguese. In: BISOL, L.; BRESCHNCINI, C. R.. Contemporary Phonology in Brazil. Newcastle: Cambridge Scholar Publishing. 2008, p.54-81.

ALVARENGA, D. Variations ortographiques, temps d'identification et apprentissage de la langue écrite portugaise: une approche phono-cognitive. 1993. Thèse de Doctorat Nouveau Régime (Linguistique)-Université de Paris VIII, Paris, 1993.

ANGLÉS, H. La música de las Cantigas de Santa María del Rey Alfonso el sabio: facsímil, transcripción y estudio critico por Higinio Anglés. v. II. Barcelona; Diputación Provincial de Barcelona: Biblioteca Central; Publicaciones de la Sección de Música, 1943.

BISOL, L. O acento e o pé métrico binário. Cadernos de Estudos Lingüisticos, Campinas, n. 22, p.69-80. 1992.

. Constituintes prosódicos. In: BISOL, L. (Org.). Introdução a estudos de fonologia do português brasileiro. Porto Alegre: EDIPUCRS, 1996. p.247-61.

COLlisCHONN, G. Acento secundário em português. Letras de Hoje, Porto Alegre, v. 29, n. 4, dez. 1994, p.43-53.

COSTA, D. S. Estudo do acento lexical no português arcaico por meio das Cantigas de Santa Maria. 2006. Dissertação (Mestrado em Lingüística e Língua Portuguesa) - Faculdade de Ciências e Letras - UNESP Araraquara, 2006. 
COSTA, D. S. Da notação musical às proeminências da fala: uma proposta metodológica para o estudo do ritmo lingüístico das Cantigas de Santa Maria de Afonso X. Comunicação apresentada no $55^{\circ}$ Seminário do Gel, Franca, UNIFRAN, 2007.

Música e lingüística: uma metodologia para estudos da prosódia do português arcaico. In: SIMCAM4. 2008. São Paulo. Anais eletrônicos... Disponível em: <http://www.fflch.usp.br/dl/simcam4/ downloads_anais/SIMCAM4_Daniel_Costa.pdf>. Acesso em: 28/05/2009.

Música e texto: uma metodologia para o estudo da prosódia de línguas mortas. Aceito para publicação em Estudos Linguísticos, n 39 , 2009.

A interface Música e Linguística como instrumental metodológico para o estudo da prosódia do português arcaico. 2010a. Tese (Doutorado em Linguística e Língua Portuguesa) - Faculdade de Ciências e Letras - Unesp - Araraquara, 2010a.

. Estudo sobre o acento secundário e a tonicidade dos monossílabos em português arcaico por meio da música e da métrica das Cantigas de Santa Maria. In: Estudos Linguísticos, São Paulo, v. 39, n. 1, 2010b, p.21-34.

D'ANDRADE, E.; LAKS, B. Na crista da onda: o acento de palavra em português. In: ENCONTRO NACIONAL DA ASSOCIAÇÃO PORTUGUESA DE LINGÜÍSTICA, 7, 1990, Lisboa. Actas... Lisboa: APL, 1991. p.15-26.

DUARTE, Y. C. M. Á. As regras de atribuição do acento primário em língua portuguesa. 1977. Dissertação (Mestrado em Linguística) - Universidade de Brasília, Brasília, 1977.

FERREIRA, M. P. O som de Martin Codax: sobre a dimensão musical da lírica galego-portuguesa (séculos XII-XIV). Lisboa: Unysis, Imprensa Nacional - Casa da Moeda, 1986.

HAYES, B. Metrical Stress Theory: Principles and Case Studies. Chicago, London: University of Chicago Press, 1995.

MAIA, E. M. Phonological and Lexical Processes in a Generative Grammar of Portuguese. 1981. Tese (Doutorado em Linguística) - Brown University, Providence, 1981.

MASSINI-CAGLIARI, G. Cantigas de amigo: do ritmo poético ao lingüístico. Um estudo do percurso histórico da acentuação em Português. 1995. Tese (Doutorado em Linguística) - IEL/Unicamp, Campinas, 1995. 
. Do poético ao lingüístico no ritmo dos trovadores: três momentos da história do acento. Araraquara: FCL, Laboratório Editorial, Unesp; São Paulo: Cultura Acadêmica, 1999.

Do ritmo musical para o ritmo lingüístico, a partir da análise de uma Cantiga de Santa Maria de Afonso X. In: SIMCAM4. 2008a. São Paulo. Anais eletrônicos... Disponível em: <http://www.fflch.usp.br/ dl/simcam4/downloads_anais/SIMCAM4_Gladis_Cagliari.pdf $>$. Acesso em: 28/05/2009

. Interface Fonologia-Poesia-Música: Uma análise do ritmo lingüístico do Português Arcaico, a partir da notação musical das Cantigas de Santa Maria. Estudos Lingüísticos XXXVII - Anais de Seminários do GEL, São José do Rio Preto, Universidade Paulista, v. I, p. 9-20, 2008b. Disponível em: <http://www.gel.org.br/estudoslinguisticos/ volumes/37/EL_V37N1_01.pdf>. Acesso em: 28/05/2009.

. Contribuição para a análise do ritmo lingüístico das cantigas profanas e religiosas a partir de uma interface Música-Lingüística. Comunicação apresentada no IX Congresso da Associação Internacional de Lusitanistas. Funchal, Madeira, Portugal, Universidade da Madeira, de 4 a 9 de agosto de 2008c.

Das cadências musicais para o ritmo lingüístico: Uma análise do ritmo do Português Arcaico, a partir da notação musical das Cantigas de Santa Maria. In: Revista da ABRALIN. v. 7, n. 1, p.9-26, jan./jun. 2008d.

METTMANN, W. Introducción. In: Alfonso X, el Sabio. Cantigas de Santa Maria (cantigas 1 a 100). Madrid: Castalia, 1986.

PARKINSON, S. As Cantigas de Santa Maria: estado das cuestións textuais. Anuario de estudios literarios galegos, Vigo, p.179-205, 1998.

WETZELS, W. L. Mid Vowel Neutralization in Brazilian Portuguese. Cadernos de Estudos Lingüísticos, Campinas, n. 23, p.19-55, jul./dez. 1992. 
SOBRE O LIVRO

Formato: $14 \times 21 \mathrm{~cm}$

Mancha: $23,7 \times 42,5$ paicas

Tipologia: Horley Old Style 10,5/14

Papel: Off-set $75 \mathrm{~g} / \mathrm{m}^{2}$ (miolo)

Cartão Supremo $250 \mathrm{~g} / \mathrm{m}^{2}$ (capa)

1a edição: 2015

EQUIPE DE REALIZAÇÃO

Coordenação Geral

Marcos Keith Takahashi 